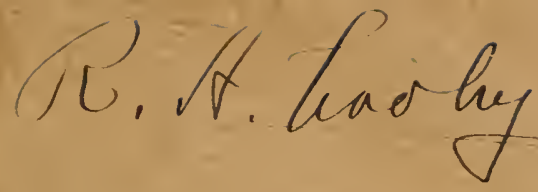

SMITHSONIAN INSTITUTION.

UNITED STATES NATIONAL MUSEUM.

\title{
DIRECTIONS FOR COLLECTING AND PRESERVING INSECTS.
}

BY

- C. V. RILEY, M. A., Ph. D.,

Honorary Curator of the Department of Insects, U. S. National Museum.

Part F of Bulletin of the United States National Museum, No. 39 (with one plate).

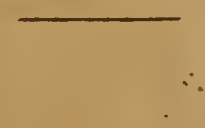

$\therefore$

WASHINGTON :

GOVERNMENT PRINTING OFFICE.

1892. 




\section{CONTENTS.}

Page,

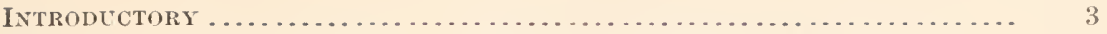

MANIAL OF INSTRUCTIONS FOR COLLECTING AXD PRESERVING INSECTS..... 5

Cilaracteristics of ixisets. . . . . . . . . . . . .

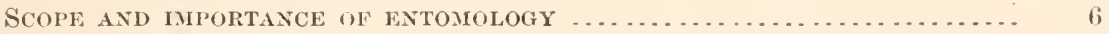

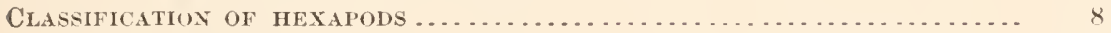

Order Hymenoptera.................................... 12

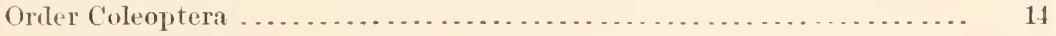

Order Lepidoptera . . . . . . . . . . . . . . . . . . . . . . . . . . . . 16

Order Hemiptera ..................................... 17

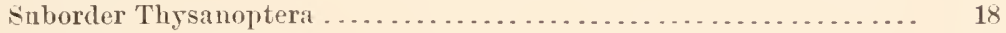

Orier Diptera ...................................... 19

Snborder Aphaniptera ............................... 20

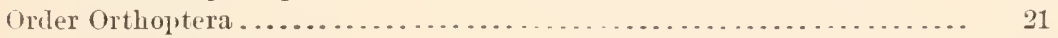

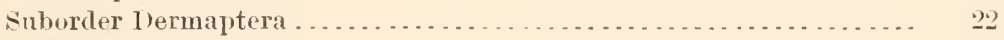

Order Newroptera.................................... 2.

Suborder Trichoptera .............................. 23

Suborder Mecoptera ... . . . . . . . . . . . . . . . . . . . . . 23

Suborler Neuroptera . . . . . . . . . . . . . . . . . . . . . . . . 23

Snborder Platsptera ............................... 24

Suborder Plecoptera ................................. 25

Suboriler Odonata .................................. 25

Snborter Ephemeroptera . . . . . . . . . . . . . . . . . . . . . . . 25

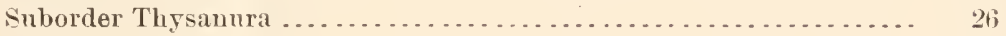

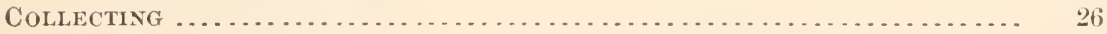

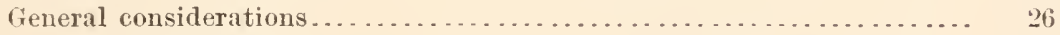

Collecting apparatus. . . . . . . . . . . . . . . . . . . . .

The sweeping net. . . . . . . . . . . . . . . . . . . . . . . . . 29

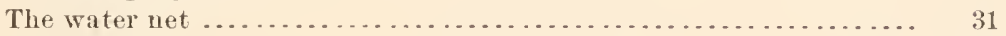

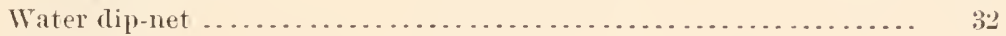

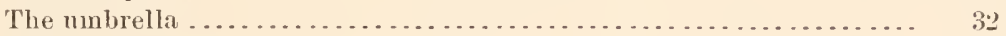

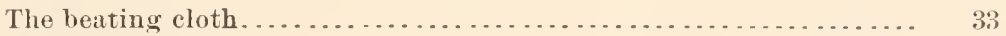

The umbrella net ................................. 34

The sieve ........................................

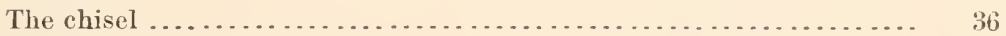

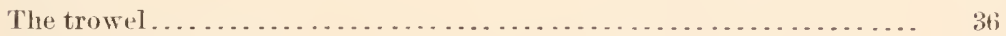

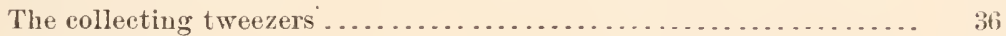

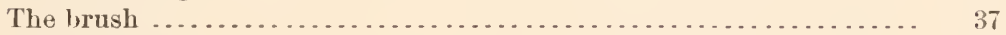

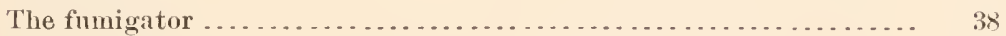

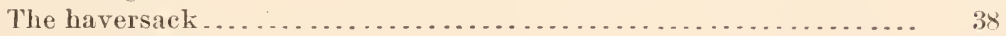

The lens and microscope .............................. 39

Collecting Hymenoptera ... . . . . . . . . . . . . . . . . . . . . . . . . . 39

Collecting Coleoptera ................................... 12

General directions . . . . . . . . . . . . . . . . . . . . . . . . . 42

Winter collectin $y . \ldots \ldots \ldots \ldots \ldots \ldots \ldots \ldots \ldots \ldots \ldots \ldots \ldots \ldots \ldots$ 
Con.lectixi-Continmerl.

collerting Coleoptera-Continuel.

spring collecting

Myrmerophibons amel Trrmetophilons species

spring thights of (oberelter:al .

Beaclı rollecting.

Attratetingr ly lights

Traplis

Fireshets.

sumumar rollerting.

Collecting muler stomes.

collecting in rotten stumps and logs

collecting in dying or diad trees.

beating living trees, slumlis, and vine

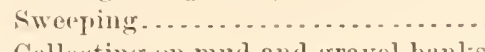

Collerting on mul and gravel banks

Collecting aquatic beetles

('ollectiun at the seashore and on sandy plines

Collecting dung beetles.

Night iollecting

Fall rollecting

(ollecting Lepidoptera

('ollecting the arlults

Collecting the early states

Collecting Hemijtera.

collecting Diptera

(collecting Orthoptera

('ollecting Nenroptera

l'sendoneuroptera

Nenroptera .

KILLING AND PIESERVING INSECTS

First preservation of living specimens.

Killing specimens.

Aleohol.

Chloroforix and ether.

Cyanide of potassimm

Other acrents

special directions for different orders

Extomotaxy.

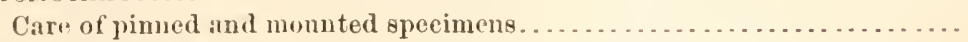

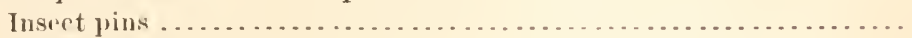

Preparation of specimens

Pimniner

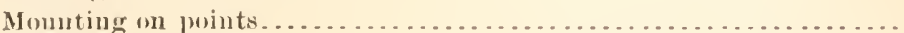

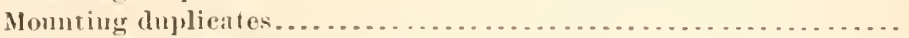

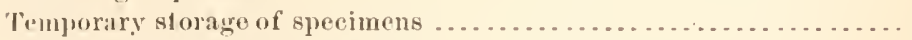

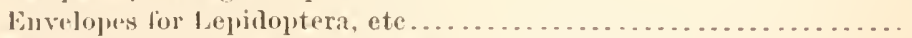

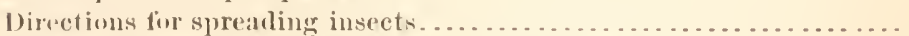

$\Lambda$ n.

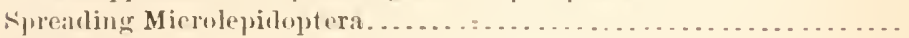

linlaxing . . . . . . . . . . . . . . . . . . . . . . . . . . . . . . .

Intlation of the larvio of Lepidoptera ........................

stufling insects . . . . . . . . . . . . . . . . . . . . . . . . . . . . . . .

Dry preservation of Aphides and other soft-bodied insects .......... 
ExToMotaxy-Continued.

Care of pinned and mounted specimens-Continned.

Page.

Mounting specimens for the microscope .................... of

Preparing and mounting the wings of Lepidoptera ............... 86

Preservation of alcoholic specimens ........................... 88

Aplaratus and methods. ................................. 88

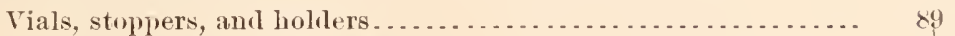

Preserring micro-larve in alcohol..................... 92

Preservative fluids ....................................... 43

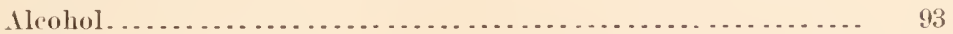

Alcohol and white arsenic ............................ 93

Alcohol and corrosive sublimate ........................ 94

Two fluids to preserve form and color. . . . . . . . . . . . . . . . 94

(ilycerin .................................................. 94

The Wirkershein preserving fluid...................... 94

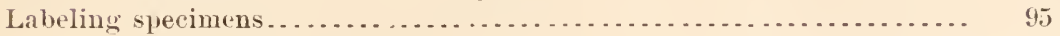

General directions ....................................... 95

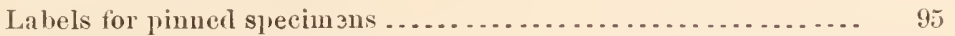

Labeling alcoholic specimens ........................ $\quad 97$

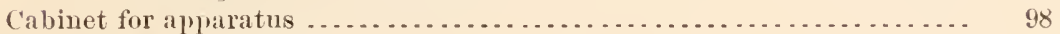

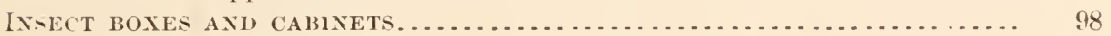

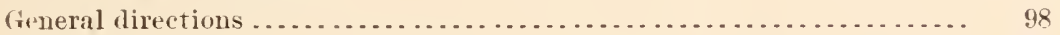

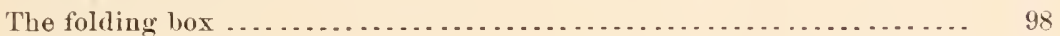

The cabinet ..................................................... 100

The Lintner display box ..................................... 101

The Martindale box for Lepirloptera .......................... 101

Horizontal rersus vertical arrangement of boxes.................... 104

Lining for insect boxes ..................................... 104

ARRANGeneNT OF INSECTS IN THE CABINET ....................... 106

Systematic and biologic collections........................... 106

Economic displays ...................................... 106

Labeling collewtions .......................................... 107

MUSECM PESTS, HoLD, ETC ................................... 108

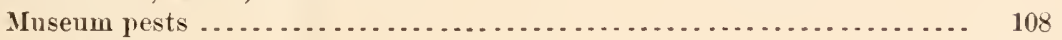

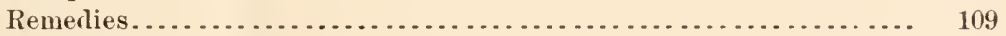

Naphthaline...................................... 109

Bisulphide of carbon . . . . . . . . . . . . . . . . . . . . . . . . 110

Mercury pellets..................................... 110

Carbolic acid .................................... 110

A weans of preserring insects in dry, hot conntries.............. 110

110

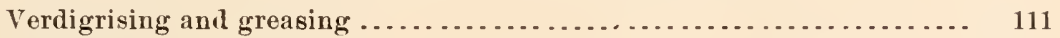

THE REARING OF INSECTS . . . . . . . . . . . . . . . . . . . . . . . . . . 112

General directions ....................................... 112

The breeding cage, or vivarinm............................. 112

Detailed instructions for lireeding ............................ 115

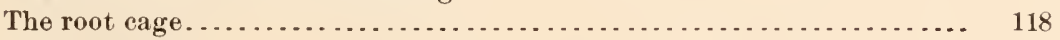

Other apparatus ... ... . . . . . . . 119

The insectary ............................................ 120

DIRECTIONS FOR PACKING AND TRANSMITTING INSECTS............... 121

Notes AND MEMORANIA .................................... 123

INSTRUCTIONS FOR COLLECTING AND PRESERVING ARACINIDS AND MYRIAPODS. 124

Directions for collecting spiders ........................... 124

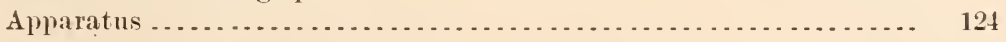

Time and locality for collecting ........................... 125 
ConlECTING-Contimued.

Collecting Coleoptera-Continued.

spring collecting

Myrmecophilous and T'ermetophilous specics

spring flights of Coleopteria

Beach collecting

Attracting by lights

Trapus

Freshets

summer collecting.

Collecting under stones

Collecting in rotten stumps and logs

Collecting in lying or dead trees.

Beating living trees, shrubs, and vines

Sweeping.

Collecting on mud and gravel banks

Collecting aquatic beetles

Collecting at the seashore and on sandy places

Collecting dung beetles.

Night collecting.

Fall rollecting

('ollecting Lepidoptera

Collecting the alults

Collecting the early states

Collecting Hemiptera.

('ollecting Diptera

Collecting Orthoptera

collecting Neuroptera

Pseudoneuroptera

Neuroptera

KILLING AND PRESERVING INSECTS

First preservation of living specimens.

Killing specimens.

Aleohol.

Chloroform and ether.

Cyanide of potassium

Other agents

Special directions for different orders

Extomotaxy.

Care of pinned and mounted speeimens.

Insect pins

Preparation of specimens

Pinning

Momting on points

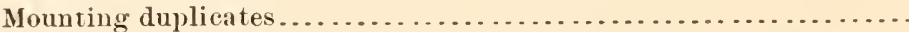

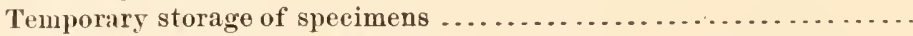

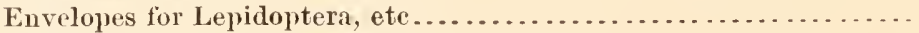

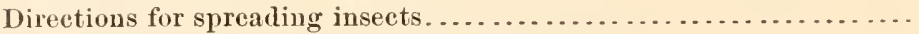

A new apparatus for spreading Microlepidoptera ................

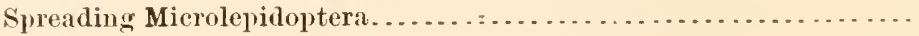

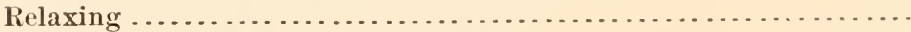

Inflation of the larva of Lepidoptera . . . . . . . . . . . . . . . .

Stuffing insects

Dry preservation of Aphides and other soft-bodied insects 
Extomotaxy-Continued.

Care of pimed and mounted specimens-Continued.

Page.

Mounting sperineus for the microscope .................... 81

Preparing and mounting the wings of Lepistoptera ............ 86

Preservation of aleoholie speeimens .............................. 88

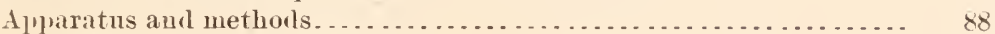

Vials, stoplers, and holders ............................. 89

Preserving miero-larvie in alcohol.................... 92

Preservative tluirls . . . . . . . . . . . ....................... 93

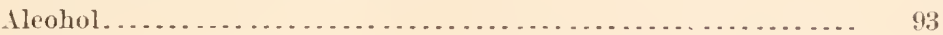

Aleohol and white arsenie .......................... 93

Aleohol and eorrosive sublimate ........................ 94

Two tluids to preserve form and color.................... 94

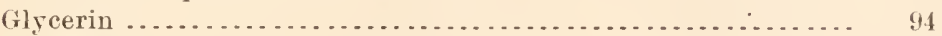

The Wiekersheim preserving tluil..................... 94

Labeling speeimens. ... . . . . . . . . . . . . . . . . . . . . . . . . . . . 95

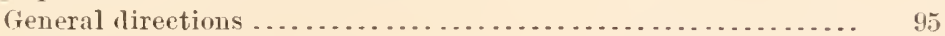

Labels for pinmed speein

Labeling aleoholic specimens ........................ 97

Cabinet for apparatus . . . . . . . . . . . . . . . . . . . . . . . . . . 98

IXEECT BOXES AXI CABINETS............................. 98

General directions . . . . . . . . . . . . . . . . . . . . . . . . . . 98

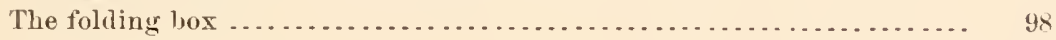

The eabinet .......................................... 100

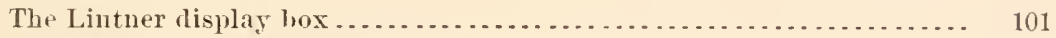

The Martindale box for Lepicloptera ... . . . . . . . . . . . . . . . . . iủ

Horizontal rersus vertical arrangement of boxes... . . . . . . . . . . . . . 104

Lining for inseet boxes ................................... 104

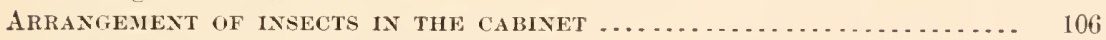

Systematic and biologie collections......................... 106

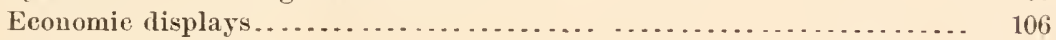

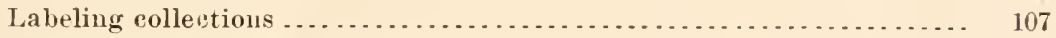

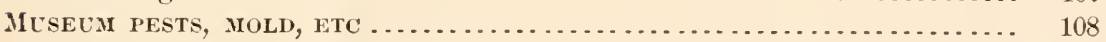

Museum pests .......................................... 108

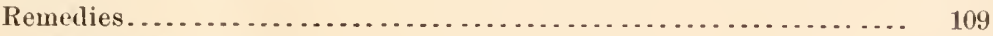

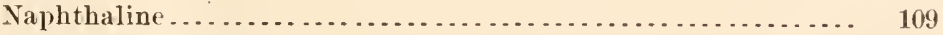

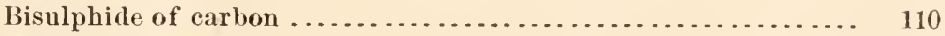

Mercury pellets.................................... 110

Carbolic acid ............................................. 110

A means of preserving insects in dry, hot countries........... 110

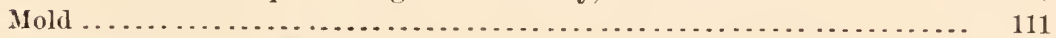

Verdigrising and greasing .................................. 111

THE REARING OF INSECTS . . . . . . . . . . . . . . . . . . . . . . . . . . 112

General direetions .......................................... 112

The breeding cage, or vivarium........................... 112

Detailed instructions for breeding .......................... 115

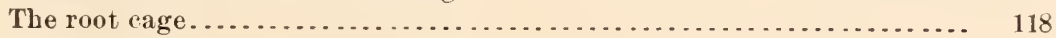

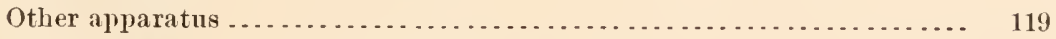

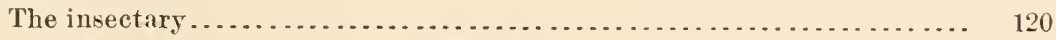

DIRECTIONS FOR PACKIYG AND TRANSMITTING INSECTS.............. 121

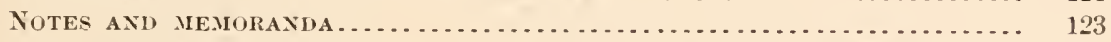

INSTRUCTIONS FOR COLLECTING AND PRESERVING ARACHNIDS AND MYRIAPODS. 124

Directions for collecting spiders ... . . . . . . . . . . . . . . . . . . . 124

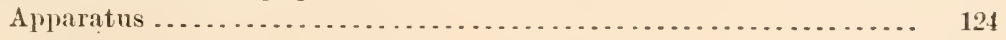

Time and loeality for collecting ....................... 125 


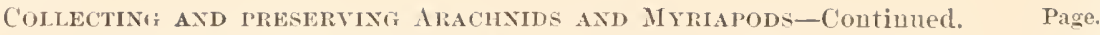

Collerting other Arachnirls, mites, ticks, scorpions, ete . . . . . . . . . 126

Collecting Myriapoda. . . . . . . . . . . . . . . . . . . . . . . . . . . 130

TEXT boOKS AND ENTOMOLOGICAL WoRKS ........................ 131

Comprehensive works most useful for the student of North American in-

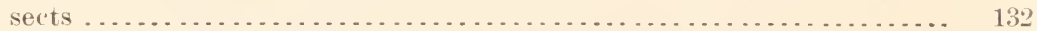

Gener.l works on classification ... . . . . . . . . . . . . . . . . .

Hymenoptura.................................. 132

Coleoptera ........................................ 132

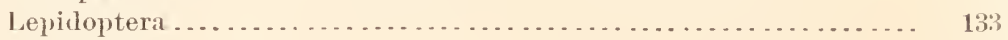

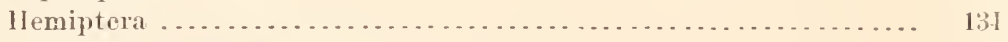

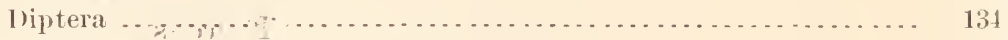

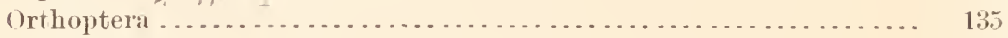

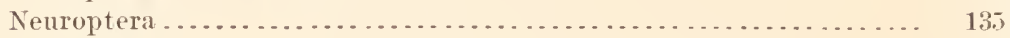

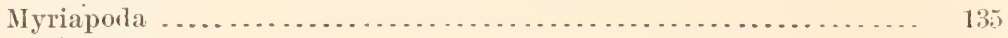

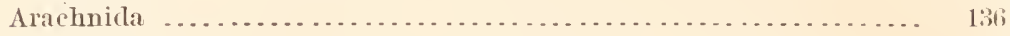

American periolicals . . . . . . . . . . . . . . . . . . . . . . . . . $13 t^{\circ}$

Fureign periolicals ................................... 138

The more useful works on economic entomology . . . . . . . . . . . . . 140

Entomological works publisher by the United States Entomological Commission and by the United States Department of Agriculture.........

Works by the United States Entomological Commission ...........

Bulletins of the Division of Entomology, U. S. Department of Agri-

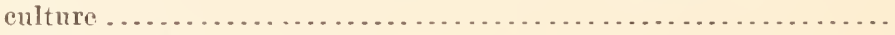

Special reports and bulletins. . . . . . . . . . . . . . . . . . . .

How to OBTARN ENTOHOLOGICAL BOOKS AND PAMPHLETS.............. 


\section{N'TOI) I C'TORY.}

There is a constant rlemand, esperially fom compespondents of the Museum and also of the Department of Agriculture, for information as to how to collext, preserve, and momot inserets. "hene; also great neerl of some simple dinections on a great many other points anmerterl with the proper packing of insects for transmission thromgle the mails or otherwise; labeling; methouls of rearing; boxes and cabinots; text-hooks, etc. Interest in the sulpject of entomology has, in fart, marle lapid growth in the last few years, and now that mearly every State has an official entomologist comnected with its State Igriconltural Experiment Station, the number of persous interested in the subject may be experted to increase largely in the mear future. I have hithere made nse of the Smithsonian Miscellaneoms Collections, No. 2261, which is a pamphlet on collecting and preserving insects preparen by I)r. A. S. Packand. This is out of print, and I late been lenpesterl by Prof. Gomde to prepare for Bulletin 39, IT. S. N. M., something that Womld cover thr whole gromud and give the nore essential information neederl for eollectors aud students of insect lite. I have deemerl it munecessary to gan too much into detail, but have studied not to omit anything essential. Cnstoms and methods vary in different comntries and with different indivirluals, but the rerommendations contained in the following pases and based "pon my own experience and that of my assistants and many acquaintances, and embrace the methods which the large majority of American entomologists have fomml most sat tisfactory.

IIteh of the matter is repeated borlily from the directions for collecting and preserving insects publisherl in my Fifth lieport on the Inserets

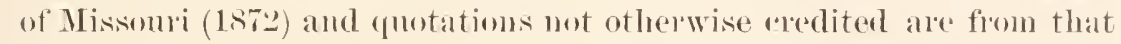
Report. The illustrations, also, when not otherwise coestited ol not originally mate for this paper, are from my previons writings. Some are taken from Dr. l'ackard's pamplulet, already mentioned; others, with the permission of Assistant Seretary Willits, from the publinations of the Department of Agriculture, while a mmber have heen especially made tor the oceasion, either from photographs, or form drawings by

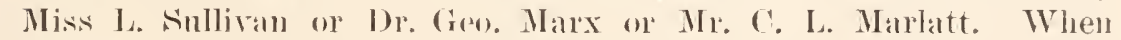
enlarged, the natural size is indicated in hair-line. In the prepal"ation of the pamplitet I hate hat the assistance of Mr. Li. A. Selowally, and more particularly of Mr. ('. L. Marlatt, to both of whom I desile Inere to express my obligations. 




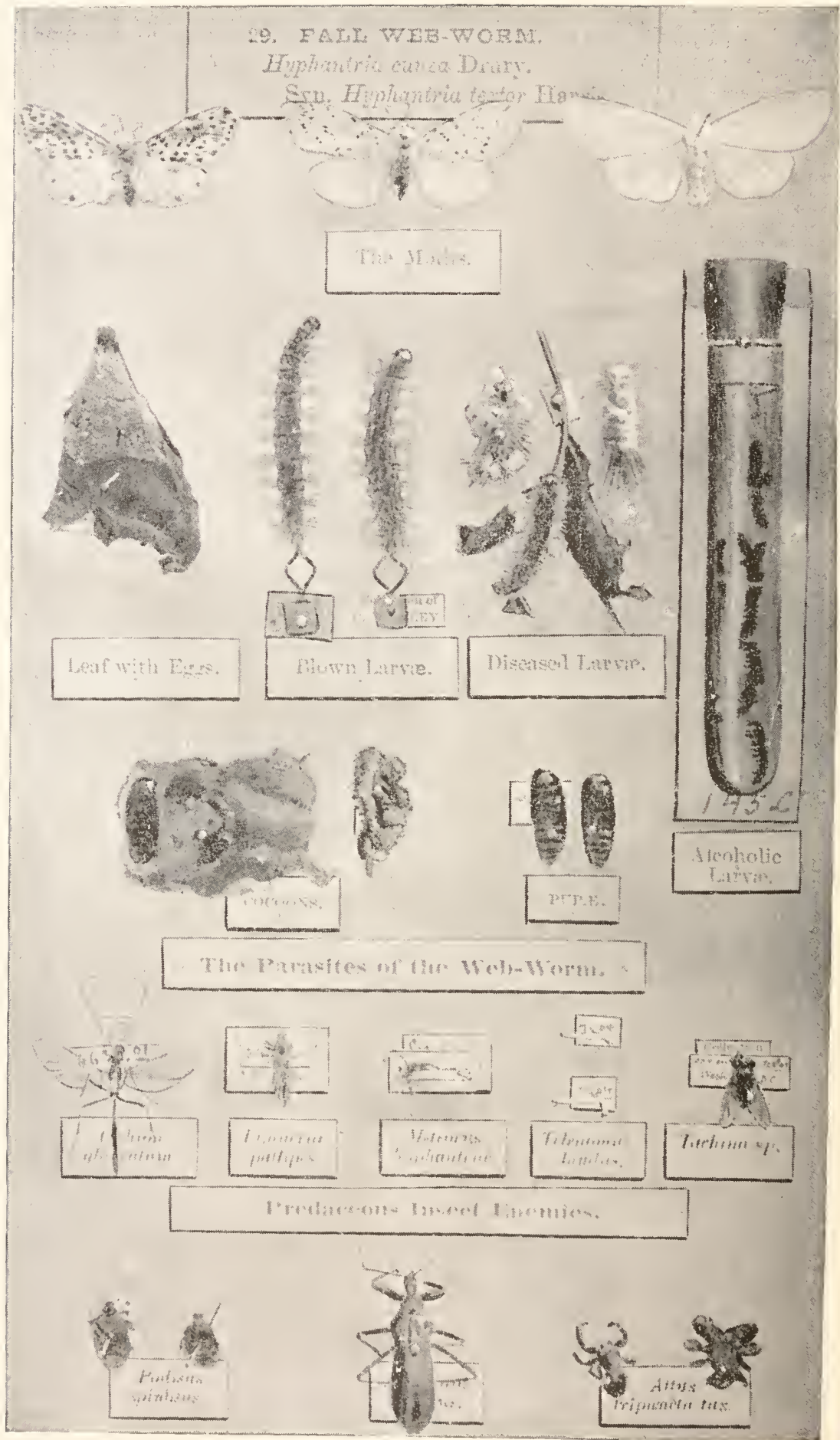

Illustration of Biologic Series. 


\section{MANUAL OF INSTRUCTIONS FOR COLLECTING AND PRE- SERVING INSECTS.}

By C. V. RILEY,

Honorary Curator of the Department of Insects, U. S. Notional Museum.

\section{CHARACTERISTICS OF INSECTS.}

The term "insect" comes fiom the Latin insectum, and signities "cut into." It expresses one of the prime characteristies of this class of animals, namely, that of segmentation. This feature of having the body divided into rings or segments by transverse incisions is pos. sessed by other large groups of animals, and was considered of sufficient importance by Cuvier to lead him, in his system of classification, to group with Insects, nuder the general term Articnlata, Worms, Crustacea, Spiders, and Myriopods. Worms differ from the other four groups in having no articulated appendages, and in having a soft body-wall or integument instead of a dense chitinons covering, and are separated as a special class Fermes. The other four gromps of segmented animals possess in common the feature of jointed appendages and a covering of chitinons plates, and are brought together under the term Arthroporda. The division of the body into a series of segments by transverse incisions, characteristic of these animals and these only, justifies the use of Cuvier's old name, Articulates, as this segmented feature represents a definite relationship and a natural division-as much so as the vertebral column in Vertebrates. The Cuvierian name should be retained as a coördinate of Vertebrates, Molluses, etc., and the terms Vermes and Arthopols may be conveniently used to designate the two natural divisions of the Articulates.

The term "insect" has been employed by anthors in two different senses-one to apply to the tracheated animals or those that breathe thronglı a system of air tubes (trachea), comprising spirlers, Myriopods, and insects proper or Hexapods, ${ }^{*}$ and the other in its restristed sense as applied to the Hexaprods only. To avoid confusion, the latter signitication only should be used, and it will be thus used in this article.

\footnotetext{
*Fom the fruek çataus, having 6 feut.
} 
TVe see, then, that insects share, in common with many other animals, the jointed or articulated structure. Wherein, then, do they differ? briefly, in having the body dirided into thirteen joints and a subjoint, including the bead as a joint, and in the adult having six true, jointed legs, and nsmally, thomgh not always, wings. The five dasses of Articulates differ from each other in the mmber of legs they possess in the adult form, as follows: Iexapoda, f legs; Arachuda, s legs: Clustalcen, 10-14 legs; Myriapoda, more than 14 legs; Vermes, mone. 'This system holds for the adnlt form only, becanse some mites (Arachnida) when yomng have only $(i$ legs, and many true insects in the lana state either have no legs at all, or have additional abrlominal legs which are not jointed, but memblanoms, and are lost in the perfect or adult state. These ale called false or prolegs.

It will serve to make these instructions deal if 1 at once explain that the life of all insect is marked by four distinct states, viz, the regs, the larva, the pupa, and the imago, and that the last three words will ronstantly reeur. We have no English equivalent for the words larva and pupal, for while some autlors have written them with the teruminal e, so as to get the English phural, yet "larves" and "pupes" so shork the ear that the terms have not been (and deserve not to be) generally arlopted.

We have seen that an insect in the final state has six true legs. Tet even here many speries depart from the rule, as there are many in whicl the perfect insect, especially in the female sex, is apodoms or without legs, just as there are also other aises where they are without wings. Sometimes the legs seem to be reduced in number by the partial or total atroply of one or the other pair, but in all these exeeptional mases there is mo diffieulty in realizing that we lave to deal with a trur inseret, becanse of the other characters pertaining to the class, some of which it will be well to allude to.

Inserts are further characterized by having usually three distinct divisions of the body, viz. : head, thosax, and abdomen, and by undergoing certain metamorphoses or transformations. Now, while a number of other animals outside of the insect world go through similar transformations, those in the Cristacea being equally remarkable, yet, from the ease with which they are olserved and the completriness of the transtomations in most insects. the metamoryhoses of this class have, from time immemorial, excited the greatest coriosity.

\section{SCOPE ANI IMPORTANCE OF ENTOMOLOGY.}

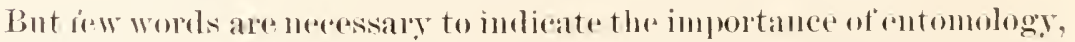
especially to the farming community; for while insects play a most important part in the economy of natme and furnish us some valuable

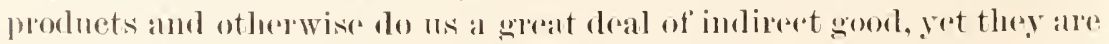

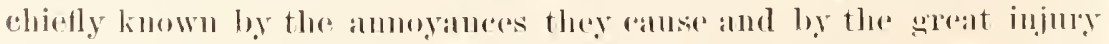

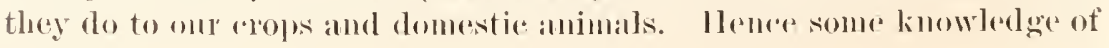


insects and how to study them heomes important, almost necessary, to evere farmex.

The seope of the seience maly best be indicated by a statement of the number of speries existing. as compared with other animals. The omminesence of insects is kmown and felt hy all; yet fow have any aecurate idea of the actual mumbers existing, so that some figures will not prove minteresting in this connection. 'Taking the lists of alescribed species, and the estimates of specialists in the different orders, it is safe to say that about thirty thomsand species lave already been deseribed from Torth America, while the number of species aheady described or to be described in thr Biologia Centrali-Anericana, i. e., for Central America, foot up just about the same number, Lord Walsingham hav ing estimated them at $30,114 \mathrm{inh}$ his adress as president of the London Entomological Soriety two rears ago, neither the Orthoptera nor the Nemoptra being inchuded in this estimate. By way of contrast the number of manmals, birds, and leptiles to be deseribed from the same region, is interesting. It foots np 1,937 , as follows:

II ammals, 180 ; birds, 1.600 ; reptiles, 157 .

If we enderor to get some estimate of the number of insests that ocenr in the whole world, the most satisfactory estimates will be found in the arldress just alluded to, and in that of Dr. David Shar p before the same society. Limbens knew nearly 3,000 species, of which more than 2,000 were European and over soo exotic. The estimate of Dr. John Iny, in 1553 , of the number of speeies on the globe, was $25(1,000$. Dr. Sharp's (stimate thirty years later was between 500,000 and 1,000,000. Shar1's and Walsinghan's estimates in 1899 reacher nearly "2,000,000, and the average number of insects ammally described since the publication of the Zö̈logical Recori, dedncting s per cent for symonyms, is ti,500 species. I think the estimate of $2.000,000$ species in the world is extremely low, and if we take into consicleration the fact that species have been best worked up in the more temperate portions of the globe, and that in the more tropical portions a rast number of species still remain to be characterized and named, ams if we take further into eonsirleration the fact that many portions of the globe are yet nuexplorerl, entomologieally, that even in the best worken up regions by far the larger portion of the Micro-Hymenoptera and Micro-Diptera remain absolutely moleseribed in wr collections, and have been but rery partially collected, it will be saf' to estimate that not one-fifth of the species extant have yot heen characterized or emmerated. In this view of the case the species in our colleetions, whether described or undeseribed, do not represent perhaps more than one-fifth of the whole. In other works, to say that there are $10,000,000$ speries of inserots in the world, would be. in my julgment, a moderate estimate. 


\section{('TASSTFICATION OF' HEXAPOTAS.}

Seven orders of insects were originally recognized by Linnsens, namely, Nemoptera, I)iptera, Heniptera, Lepicloptera, Coleoptera, Hymenoptera, and Aptera. This classification was based on the organs of flight only, and while in the main resulting in matmal divisions which still fumish the basis of more morlern classifications, was faulty in several particullans. For instance, the Aptera, which inchded all wingless insects, was soun found to be a very unnatural assemblage and its components were elistributed among the other orders. The establishment of the order Orthoptera by Olivier to include a large and well-defined glenp of insects associated with the Hemiptera by Limmens, restored the original seven orders, and this reassification lats, in the main, been followed by eutomologists up to the present time.

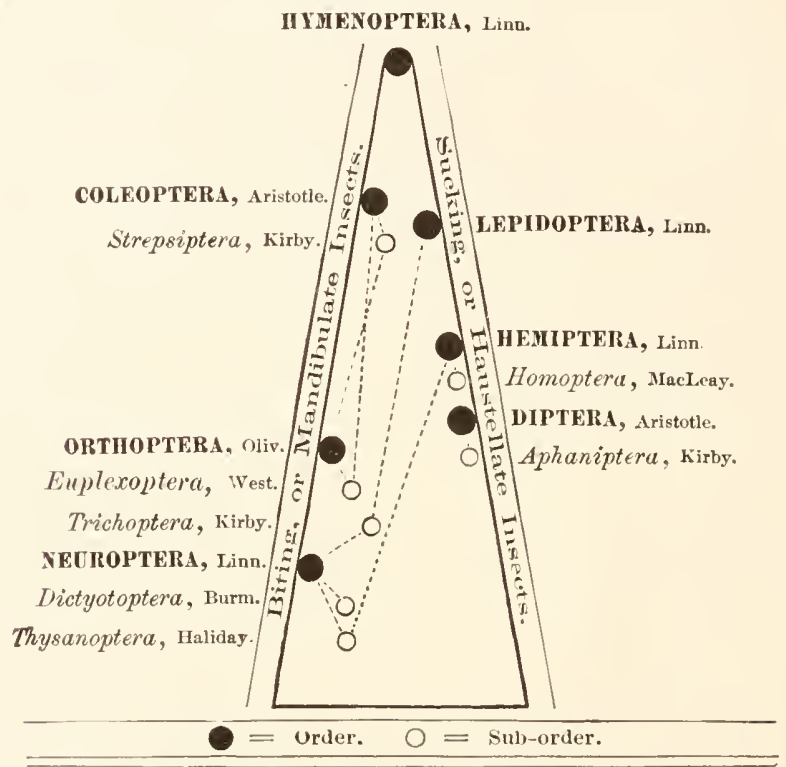

FIG. 1.-Pyramid showing the nature of the mouth, and relative rank of the Orders, and the affinities of the sub-orders of Insects.

111 insects are, in a broal way, referable to one or the other of these seven primary orders by the structure of the wings and the character of the month-parts in the imago, amb by the natme of their transformations.

Some of these orders ane commected by aberrant and osculant families of aromps, which have by other authors been varionsly ranked as iudependent orders, but which, following Westwood substantially, l have fonsidered, for convenience, as suborders. (See Fifth Report, Insects of Missomi, ete., 1572.)

In the article just citerl, I marle use of the atecompanying dian tha form of a py"amid (Fig. 1), which gives a graphice representation of

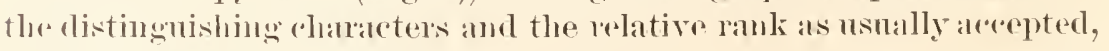
of the orders and suborders.

Full disctssion of the different rassifuations is momeressidy in this 
connertion. Anthors have difleserl in the past and will differ in the futme as to what constitutes a natmal system. and it would lequire many pages to give even a bricof survey of the varions schemes that have been proposed. As I have elsewhere said, "We must remember" that classifications are but a means to an end-appliances to facilitate our thonght and study-and that, to nse Spencer's words, "we cannot, by any logical dichotomies, actually express relations which in nature garluate into each other insensibly.".

The most philosophical, perhaps, of the more modern systems of clas. sifuation is that of Friedrich Braner, who has earefully studied the subject, ancl has given us an arrangement eonsisting of sixteen orrers. This has many merits and has been adopterl, with slight morlifieations, by Packard in his "Entomology for Beginners," and by Hyatt and Arus in their recent and valuable text-book "Insecta." Comstock, in his "Introdnetion to Entomology" strongly recommends Braner's classifieation, but for reasons of simplicity and convenience adberes to a modification of the old classification of Westwood.

For purposes of comparison the classification by IJatt and Ams, which is substantially that of Bratuer, may be introduced.

In linear arrangement it is as follows:

I. 'Thyssamura (Springtails, ete.).

II. Ephemeroptera (Ephemeridu; May-flies). (=Plectoptera Park.)

III. Odonata (Libellulide; Dragon-flies).

IV. Pleroptera (Perlide; Stone-Hies).

V. Platyptera (Termites, Mallophaga, ete.).

VI. Dermaptera (Forficulide; Earwigs).

VII. Orthoptera (Locustr, Grasshoplers, etc.).

VIII. Thysanoptera (Thripide; Fringe-wings).

IX. Hemiptera (Bugs).

X. Coleoptera (Beetles).

XI. Nenroptera (Sialide, Hemerobiida; Lace-wings, ete.).

XII. Mecoptera (Panorpida: Scorpion-flies).

XIII. Trichoptera (Phryguneidu; Caddis-flies).

XIV. Lepirloptera (Butterflies aud Moths').

XV. Hymenoptera (Bees, Wasps, ete.).

XVI. Diptera (Two-winged flies).

The relationship of these orders cannot be indicaten in a linear arrangement, and is almirably shown by Hyatt and Arms by means of diagrams which I reprotuce (Figs. 2, 3.) 


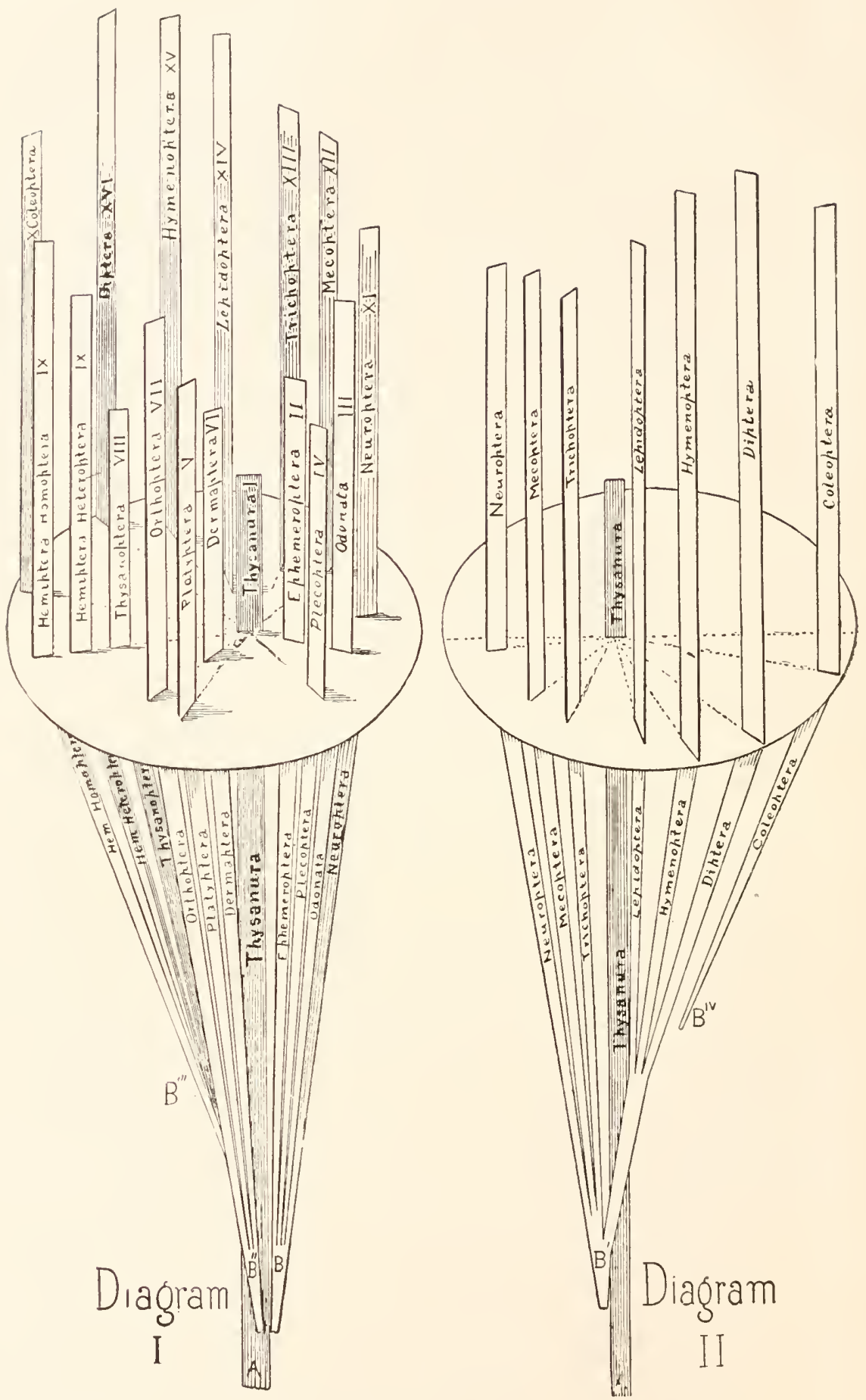

Fig. 2.- Scheme illust rating origin and relationship of Omders. (After H yatt.) 
The relation of these sixteen orders to the older, septenary seheme is shown by the following arrangement:

1. Hymenoptera .. Hymenoptera $\mathrm{ST}^{r}$.

2. Coleoptera ..... Coleoptera X.

3. Lepidoptera .... Lepidoptera XIT.

4. Heminterar (Hemiptera IX..... Heteroptera.

Thysanoptera VIII.

․ Dipterat ..... Iniptera XVI. Incheling Aphaniptera or Si-

6. Orthoptera .... \{ Orthoptera VIÍ.

(Dermaptera VI.

1. Simropteral....

Trichoptera Xill

$\left.\begin{array}{l}\text { Mecoptera XII } \\ \text { Nemroptera XI }\end{array}\right\}$ Neuroptera.

Platyptera V'

Plecoptera IV

Orlouata III Pseulo-nenroptera.

EpliemeropteraII

Thysanura I

It will be seen that the changes are not so great as would at first aplear. The three more important onders, namely, the Hymenoptera, Colroptera, and Lepirloptera. remain substantially the sane in all classifications, and so with the three orders next in importance-the Heniptera, Diptera, and Orthoptera. All that loas been done with these

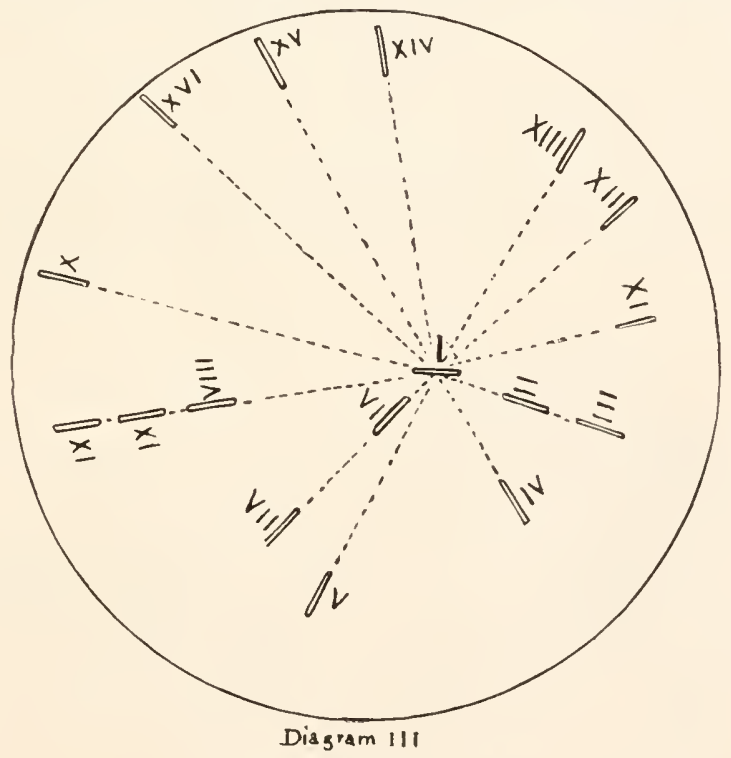

Fic. 3. - Cruss section of Fig. 2 .

there has been to rank as separate orders what hy former anthors were preferably considered as ejther fandilies or suborders. The princi-

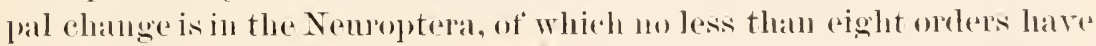
been matre. 'This is not to be wondered at, lecanse the order, as tormerly constrmel, was conceded to be that which repuesents the lowest 
forms and more synthetic types of insects, and as snch necessarily containerl forms which it is difficult to rlassify dofinitely.

In the disenssion of the characteristics, habits, nmber of species, and importance of the several gromps, I follow, with such changes as the advances in the science of entomology have made necessary, the arrangement shown in Fig. 1.

"Order HYMEXOPTERA ('upry, a membrame; $\pi \tau \approx \rho o ́$, wing'). Clear or Membrane-winged Flies: Bees, Wasps, Ants, Saw-tlies, ete. Characterned by having four membanous wings with comparatively few veins, the hind part smalkst. The transformations are complete: i. e. the larva bears no resemblanee to the perfect insert.

-Some of the insects of this order are highly specialized, and their mouth-parts are fitted both for biting and sncking, and in this respect

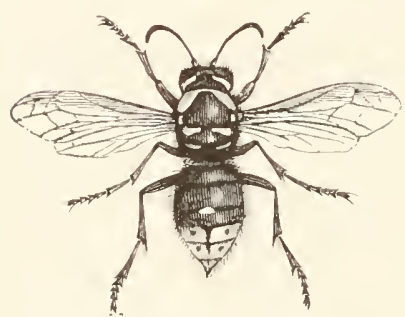

F1G. 4.-Bald-facad Hornet, Tesur inaculata. (After sanlorn). they comect the mandibulate and hanstellate insects. The common Honey-bee has this complex strueture of the month, and if the editors of onr agrienltural papers would bear the fact in mind, we shonll have less of the never-ending discussion as to whether bees are eapable of injuring fruit at first hand. The lower lip (labium) is modified into a long tongne, sheathed by the lower jaws (maxille), and they can sip, or, more properly speaking, lap up nectar; while the upper jaws (mandibule), though not generally used for purposes of nandncation, are fitted for biting and cutting. The Hymenoptera are terrestrial, there existing only a very few degraded, swimming forms.

"This order is very naturally divided into two seetions-the ACLLEATA and Terebran'ra. The aculeate Hymenoptera, or Stingers, comprise

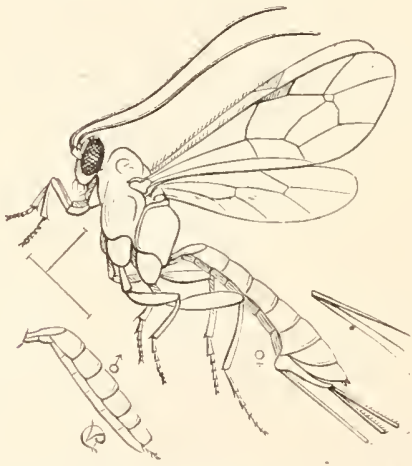

Fig, 5,-An Ichneumon Parasite, Pimpla annulipes, showing male and femite ablomen.

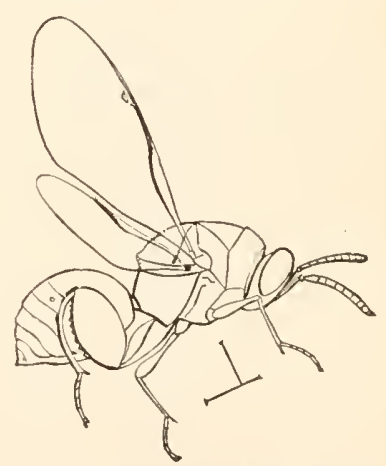

Fic, 6.-A Chalcid Parasite, Chal. cis flaviprs.

all the familes in which the ablomen in the female is ameel with a sting connected with a poison reservoir, and may be considered the typical 
form of the order, including all the sereial and fossorial speeiss. The inserts of this section must be considered essentially beneficial to man,

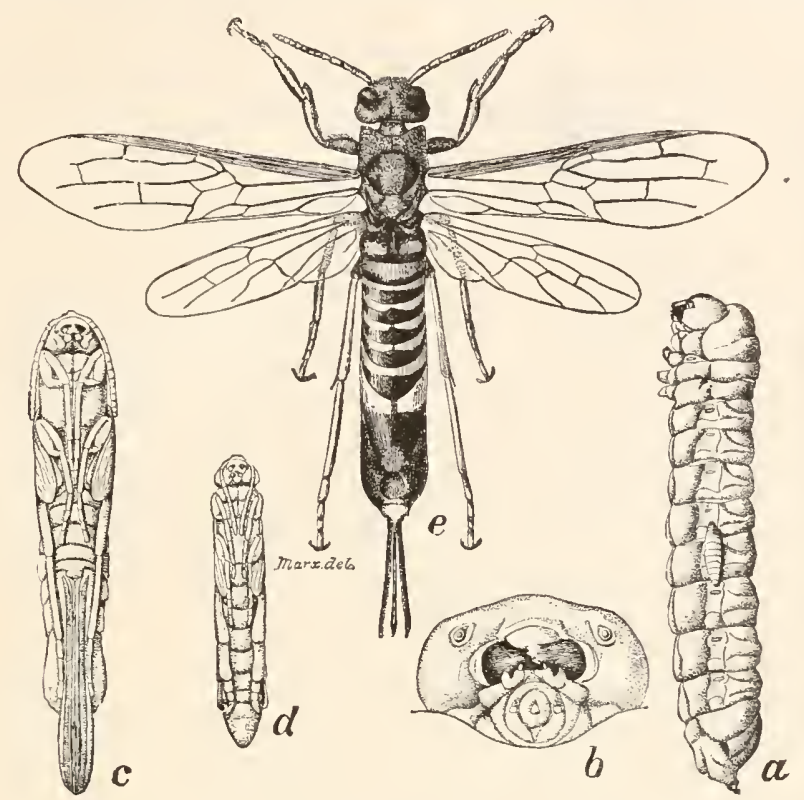

lik. 7.-A Horn-tail, Tiemex columba. a, larva, showing Thalessa larva attached to its side; $b$, head of larva, front view, enlarged; $c$, fimale pupa, ventral view; $d$, male pupa, veutral view; e, adult female-all slightly enlarged.

notwithstanding the oceasional sting of a bee or wasp, the horing of a carpenter bee, or the importunities of the ommipresent ant. Not only do they furnish us with honey and wax, hut they play so important a fart in the destruction of insects injurious to regetation that the may bo looked upon as God-appointed gillards orer the vegetal kingdom-carrying the pollen from plant to plant, and insming the fertilization of dicecions species, and the "ross-fertilization of others; and being ever rearly to clear them of herbivorons worms which gnaw and destroy. The whole section is well charasterized by the miformly maggot-like matme of the larva. The transformations are complete, but the elitinous larval covering is often so very thin and delicate that the budding of the members, or gradnal growth of the pupa underneath, is quite platinly visible, and the skin often peels oft" in delicate flakes, so that the transition from larval to pulpa is not so marked and sudden as in those insects which have thicker skins.

"The tercbrantine Hymenoptera, or Piercers, are again divisible into two subsections: first, the EnToyophags, which are, likewise, with the exereption of a few gall-makers, benefieial to man, and inchude the parasitic families, and the gall-flies; second, the PHytophaga, comprising the Horn-tails (Uroceride), and the Saw-Hies (Tenthredinide), 
all of which are regetable feeder's in the larval state. those of the first family boring into trees, and those of the second rither feed-
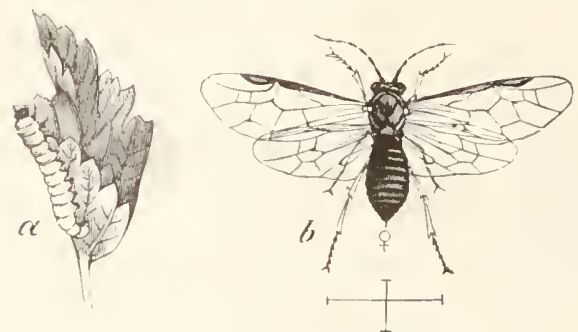

Fig. 8.-Sawfly and Larra. Pristiphora grossularie, a, larra; $b$, imago. Walsh. ing externally on leaves or inclosed in galls. They are at once distinguished firon the other Hymenoptera ly the lanve having true legs. which, howeres, in the case of the Hormtails, are very small and exarticulate. The larve of many Saw-Hies have, besidles, prolegs, which are. however, always distinguishable firm those of Lepidopteroms larvat ly being more mumerous and by having no hooks.

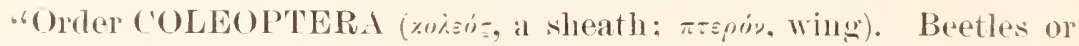
or Shield-winged Inserets. Characterized by having four wings, the front pair ("alled sytro) homy or leathery, and minally mited down the back with a straight suture when at rest, the hind ones membranons aurl folded ne meler the elytra when at lest. Trausfomations ("omplete.

"This is an order of girat innortance, ancl in the vast number and diversity of the species romprisen in it ontranks any of the others. The ease with which the insects of this ordex are ohtained and preserved make it one of the most attractive to the amatem, and beetles are, perhaps, of all insects, the best known and muler-

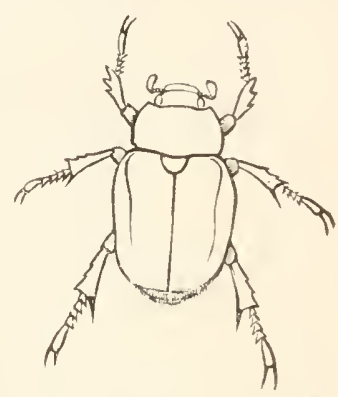

Fig. 9.-A Clater, Cutalpa laninera. (After Packiarl.) stood in the popnlar mind. For the same reason they have, in the perfect state, received most attention from the entomologists, but their transformations and preparatory forms yet ofter a wide and inviting

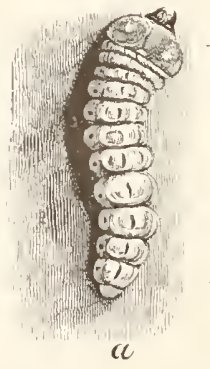

Fig. 10.-A Longicorn, Saperda cendida, a, larva; b. pupa; e, lex+tle.

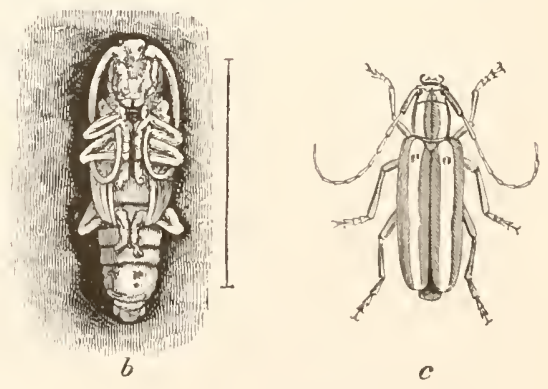
field for the student. The simplest and best-known classitioation of the
beetles is the tarsal system. fommded on the number of joints to the tarsi, by which we get four great sections: (1) PENTAmend, in which 
all the tarsi ane 5-jointed; (2) HeTERounga, with the foul ante lior o-jointed and the two posterior 4-jointed; (3) PsEudo-TETRA MERA, with apparently only four joints to all the tarsi, though, in reality, there is a fifth penultimate joint, dimimutive and roncealed; (4) Pseudo-Trimera, witl apparently only three joints to all the tarsi. This system, like most others. is not perfect, as there are mumeroms species not posvessing five joints to the talsi belonging to the first section; and for practical furposes beetles may be very well arrangerl according to halsit. We thus gert, first, the ADEPIIAGA, ar carnivorous species, including all those which

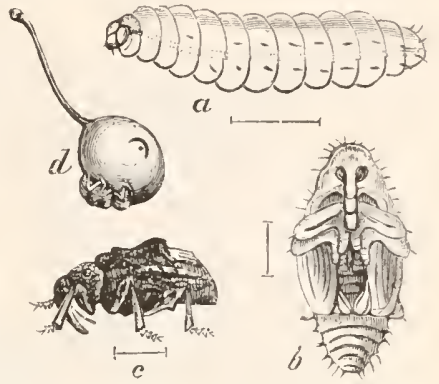

Fig. 11.-The Plum Cureulio. Conotrache. lus nenuphar. a, larra; b, pupa; $c$, beetle; $d$. plum showing egg-pumeture and crescent. prey on other living inserots, and to which, following Mr. Malsh, I have, for olvions reasons, applied the suggestive trom 'Camuibal'; secomr,

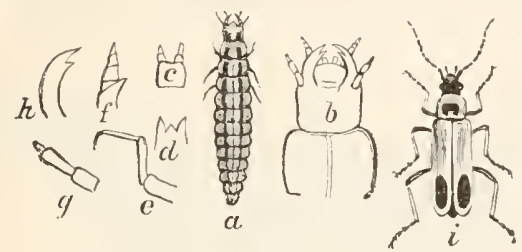

FIG. 12.-A soldier-beetle, Chauliomathus pennsylvanicus. $a$, larra; $b-h$, jarts of larvat enlarged ; $i$, beetle.

the NeCropilaga, (o)mplising these which feed on carrion, dung. fungi. and derayiug regetation; thild. the Phytopiratid, mombraing all those feeding on living vegetation. This ar'rangement is by mo moans perfort, for there are bertles which ale aarnivolous in the larva and herbivorous in the imagostate; whilusome of the Necropilagd ale actually parasitiv. Tet, it is not more artificial than others which have been proposed. The carnivorous species, broally speaking, are Pentemerous, the only striking exception boing the Coccinellidie (Lady-birks), which are Pseudo-trimerous. The carrion-feeders ans also Pentemerous; but reg

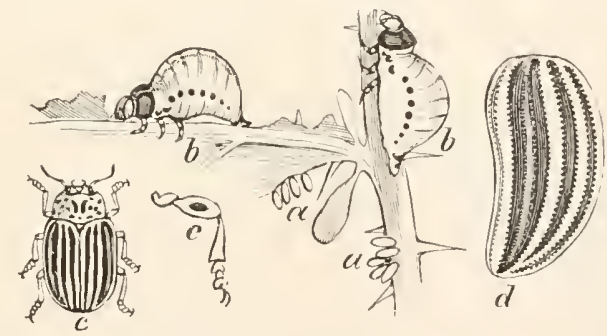

Fifr.13.- The Bogus l'otato-beetle, Morywhora juncta. a, eggs: $b$, larvas; $c$, beetle: dande, parts of best le enlargeri.

etablefereles are fomml in all the tarsal divisions, thomgh the Psendo. tetramere are the more essentially herbivorons, and aomsequently the inost injurious." 


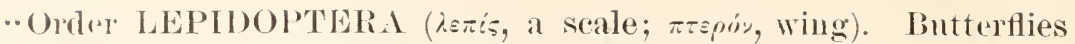
and Moths, or scaly-winger insects. Characterizel hy having four
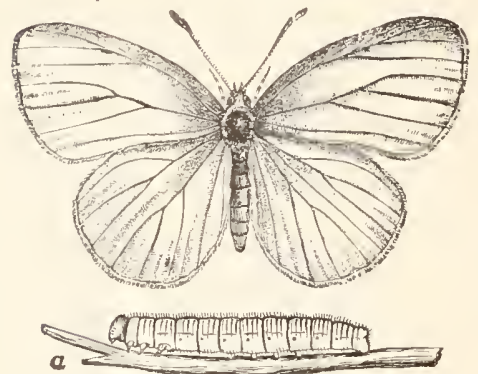

FIG. 14,-1 Butterfy, Tieris oleracea.

branching-vained membranons wings, each more or less densely covered on both sides with minnte inbricated seales which are attached by a stalk, lut which easily rub oft, and iplear to the maided eye like minute partieles of glistening dust or powder. Transformations complete.

"Next to the Lepidoptera, the Cole. optera are, perluaps, most familiar to the popular mind. Every one admiles the beanty of these frail creatures, dresised in every conceivable pattern, and adorned with every conceivable color, so as to rival the delicate hues of the rainbow, and eclipse the most fantastic and elaborate designs of man. When magnified, the scales, to which this beaty of pattern and rolor is entirely dice, present all mammer of shapes. alceorting to the particular species or the particular part of the indivichal from which they are taken. Aceoring to Lewenhoeck, there are 400,000 of theses sales on the wing of the common silk-wol'm.

"The transformations of these insects ane complete,

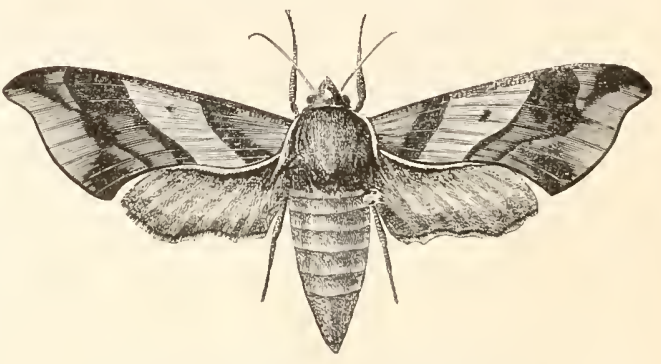

FIG. 15.-A Splingid, Ampelophaga myron. and the changes aw nsmally so sudden amb striking as to bave excited the wombler and admination of observers firom earliest times.

"The more common form of the larva is exampled in the ordinary caterpillatr-a cylindrical worm with a head. twolve joints and a sub-joint;

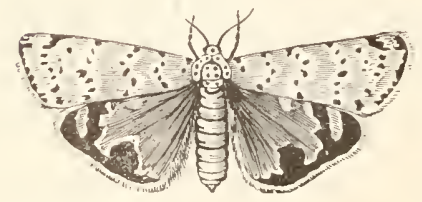

Hit, 16, - A Moth, letheisa belle. six thoracic or true legs, fonl abolominal and two anal prolegs. But there is a eneat variety of these larvac, some having no lege whaterere, some having only the jointed legsis, and others having citherforle, six, eight, or ten, hut never mores than tem polegs. With firw exoretions they alle all vegetable-ferelers, amel with still fowel exceptions, terrestrial. The preforet insects make fire nse of thein anple wings, but walk little; and their legs are watk, and not morlified in the varions ways so loticeable in othere orters, while the font pair in some buttertlies are impotent.

"As an order this must be considered the most injurioms of the seven. 
"A convenient system of classification for the Lepidoptrat is based on the structure of the antemae. By it we get two great sections: 1st, Butterflies (RHOPALOCERA): 2d, Moths (HETEROCERA), which lattel may again be divided into Crepusenlar and Nocturual Moths. Butterflies are at once distinguished from moths by their antemuxe being straight, stift and kinobbed, and by being dav-flier's or diumal:

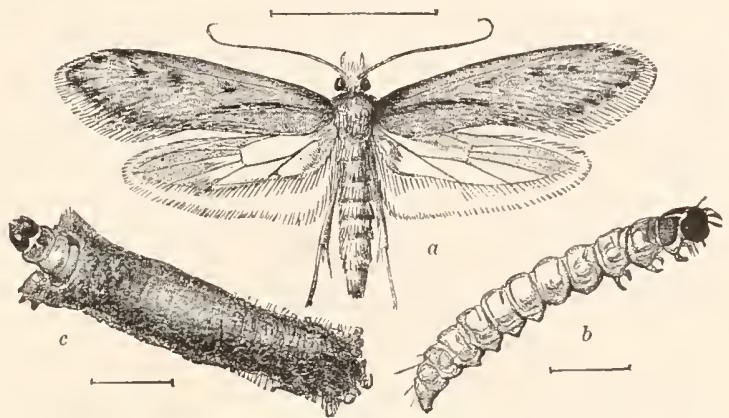

FIG. 17.-A Clothes-moth (Tinea pellionella)-(enlarged. $a$, adult; $b$, larva; c, larra in case.

while moths have the antenma tapering to a point, and are, for the most part, night-flyers or nocturnal. The crepuscular moths, composed mostly of the Sphinges or IIawk-moths, hover over flowers at ere, and connect the two sections not only in habit, but in the character of the antenna which first thicken toward the end, and then suddenly terminate in at point or hook.

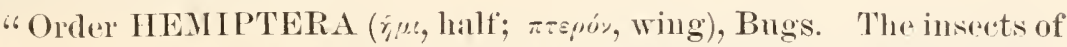

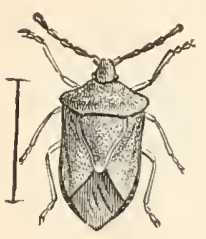

Fig. 18.-A Plantbug (E'uschistes punctipes). this order are naturally separated into two great sections; 1st, Half-winged Bugs, or Heteroptwra (हैंspos different; $\pi \tau$ s, is, wing) having the batsal half of the front wings (called hemelytra) coriaceous of leathery, while the apical part is nembranous. The wings cross flatly orer the back when at rest; "d, Whole-

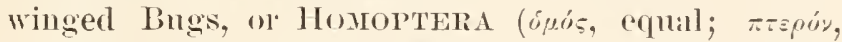
wing), having all four wings of a miform membranous nature and folding straight down the back when at rest. The latter, if separated, maty bo looked npon as a suborder.

"Transformations incomplete; i. e., the larva and pupa have more or less the image of the perfect insect, and differ littlo from it except in larking wings.

. The gemuine or half-winged Bugs (Figs. 18 and 1!) are nsually flattened in form, when mature; though mor romoled in the adolescent stages. They may be divided into Land Bugs (Amrocorisa) and Water bugs (Hydrocorisa). Tha species of the first division very generally possess the power of enitting, when disturbed of alamed,

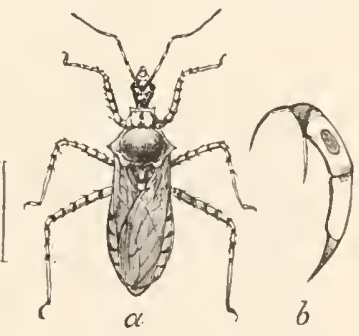

Fig. 19.-A Soldier.bug (Milyas cinetus). $b$, beak enlarerul. a louseous, becl-buggy odor, which comes from at fluid secreted $2 \pi 64$ -' 
from two pores, situated on the nnder side of the metathorax. Surh well-know inserts as the Berl-bug and Chinch-bug

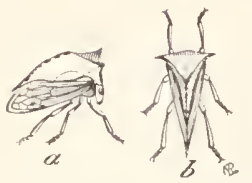

Fig. 20.-A Tree-hop. per (Ceresa bubalus). a, sille; $b$, to] riew. helong here. Tho habits of the species are valied, and while some are beneficial, others are quite injuri. ous to man.

"The Whole-winged Bugs (Figs. 20 and "21), on the contrary, are all plant-feeders, and with the exiep tion of a few, such as the Cochineal and Lac insects, are injurions. The secretion of a white, or bluish, waxy, or farinose substance from the surface of the body is as characteristic of this section as the nauseoms odor is of the first. It forms three natural divi sions, arranged aceording to the number of joints to the tarsi-namely TrIMERA, with three joints; DrMera, with two joints, and Monomera, with one joint to the tansi."

Subordor' THYsANOPTERA

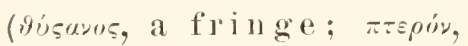
wmg): This suborder contains the single family Thripide, which comprises minute insects rommonly known as
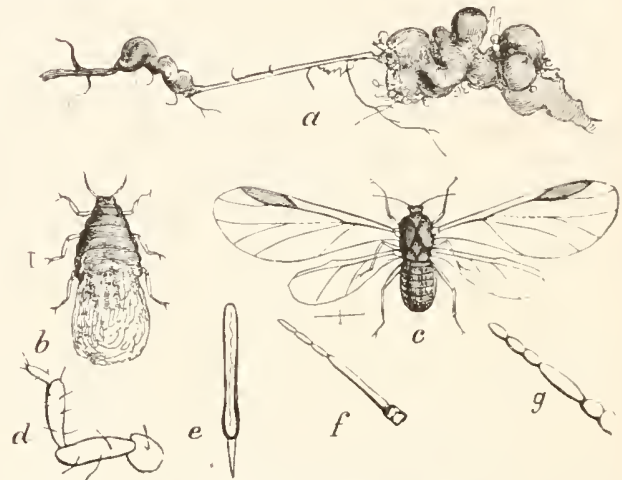

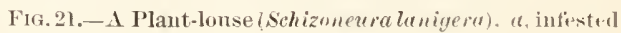
root; $b$, larra; $c$, winged insert; $d-y$, parts of pertect insect inlarged.

Thrips, and of which a common species, Thrips strintus, is shown in the accompanying figure. (See Fig. '2.') They bear strong relations to both the Psendonemoptera and the Hemiptera and by later writers are generally associated with the latter order. They feed on plants, puncturing and killing the leaves, or on other plant-feeding species of their own elass, and are characterized by having narow wings crossed

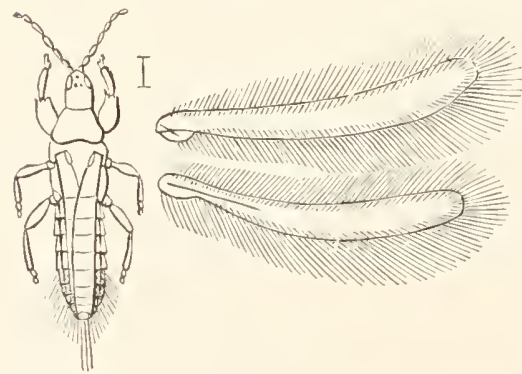

Fig. 22.-Thrips striatus, with wings enlarged at sille.

on the batk when at rest, and beantifully fringed, from which latter foature the name of the suborder is derived.

The moutl parts are peculial in that they are intermediate in form between the sucking beak of Hemiptera and the biting nouth parts of other inserts.

Their egas resemble those of Hemijtera; the larvat and pulpie are active, and in torm lesemble the adult, except in the absence of wings. Somes speries, also. alle winglesin the alult stage. 
The pupa ane somewhat shogish and the limbs and wings ane enrosed in a thin membune whiols is expanded about the feret into bulb-

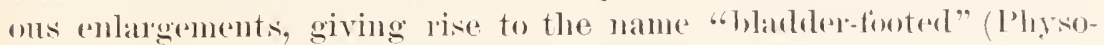
poral applied to these inserts by Bumeistel.

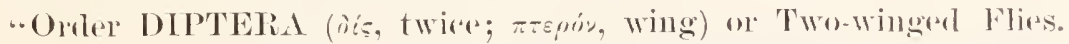
The only onder having but two wings, the hind pair replated ly a pair of small, slender filaments rlubberl at tipl, amb ralled halteres, poisers, or halallo'sts.

"No oreler sumpasses this in the number of species or in the immense swallms of individuals belonging to the same species which are frecpuently mot with. The wings, which are valionsly veined, though apjearing naked to the imaided eye, are oftroll thickly covered with very minute hairs or hooks. As all order the Diptera alle decidedly injurious to man, whether we eomsider the anmoyances to ome

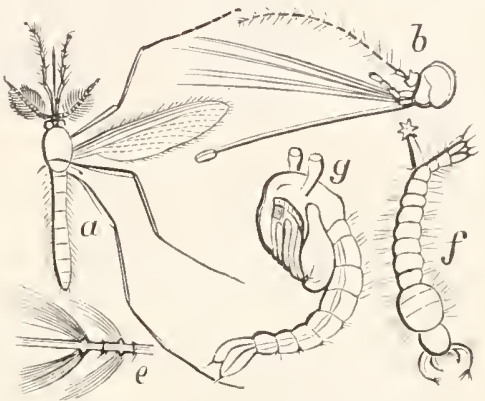

F1G. 23.-A Xlospuitu ('uiex pipiens). $t$, alult; $b$, hear of same enlarged; $e$, portion of antenna of same; $f$, larva; $g$, pmpa. (After West wond.) selves or om animals of the Mosfuito, Buffalo-guat, (xald-fly, Breeze-fly,
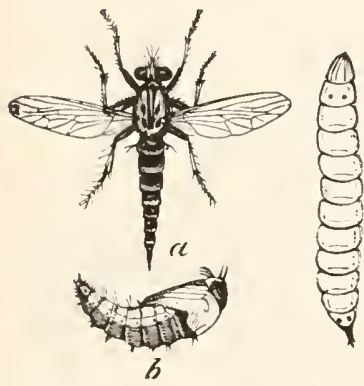

FIG. 24.-A IIawk-fly ( $\operatorname{Erax}$ bas. fardi). a purfect insect; $b$, juј) larva shown at sirle.

zimb or Stomoxys, ol the injury to olu (rops of the Hexsian-fly, Wheat-minge. ('al)bage-maggot, Onion-maggot, ete. There are, in fact, hut two families, Syrphida and Tachinida', which ean be looked mpon as beneficial to the coltivator, thomegh many art the part of scavengers. No inserets. not event the Lepidoptera, furnish suleh a valuety of roxious larval chanaters, and nome, perbaps, offer a willer or more interesting firelel of inrestigation to the biologist. It is refitionlt to give any very satisfactory arrangenent of these 'T'wo-wingerl thes, thongh they easily fall into two rather artificial sections. These are: 1st, Nenocera, or those with long antemux, having more than six joints, and palpi hasing fomr or five joints The pulua is maked, as in the Levioloptera, with the limbs exposed. This kimel of pupal is alled obtected. 2d, BrarnoCERA, or those with slort antenuat. not having more than thee distinct joints, and jalpi with one or two

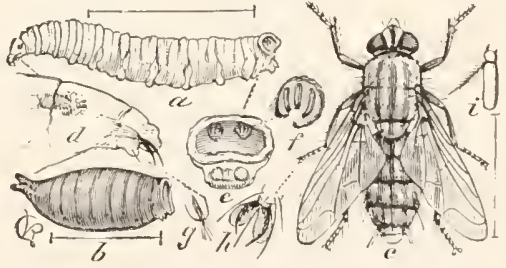

lig. 25.-A Flesh-fly (Sarcophaga camaria, var. saracence). $a$, larva; $b$, puparium; $c$, alult insect with eularged prorts. joints. The pula is mostly aocetute, i. e., is formenl within, and more 
or less completcly commerted with, the hardened and shmuken skin of the latria.

"The most anomalons of the Diptera are the Forest-flies and Sheepticks (Hippoboscille). They have a homy and flattened body, and resemble lice in their parasitic habits, living beneath the hair of bats and hirds. Their mode of development has always attracted the atten-

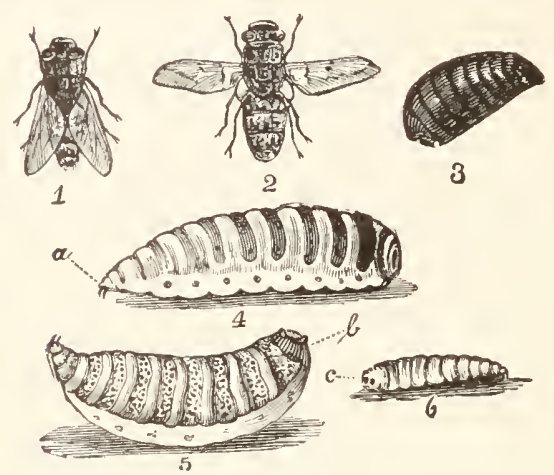

FIG. 26.-The Sheep But (restrus ovis). 1, 2, Hies;

3. purparium ; 4, 5, and 6, larva or bots. tion of entomologists. The larve are hatched in the abodmen of the female, which is capable of distention. There it remains and, after assuming the pupa state, is deposited in the form of a short, white, egg-like object, without trace of articulation, and nearly as large as the abdomen of the female fly. Closely allied to these are the Batticks ( $N$ yeteribide), which possess neither wings nor balancers, and remind one strongly of spiters.

"In this order we may also place certain wingless lice (such as Braula caced, Nitzseh), which infests the Honey-hee in Enope, northern Africa, and western Asia, but which has not vat been detecterl in this comntry.

"Suborder ApIIANIPTERA (decurs, inconspicuons; $\pi \tau \varepsilon \rho n$, wing) or Fleas, comprising thr single fimily Pulicidie, now plared with the Diptera. Everybody is supposed to be fomilia with the appearance of the Flea-its boodthinsty propensities and amazing musculat power; and while everyone may not have the leismre and means to exjericure the exhilarating

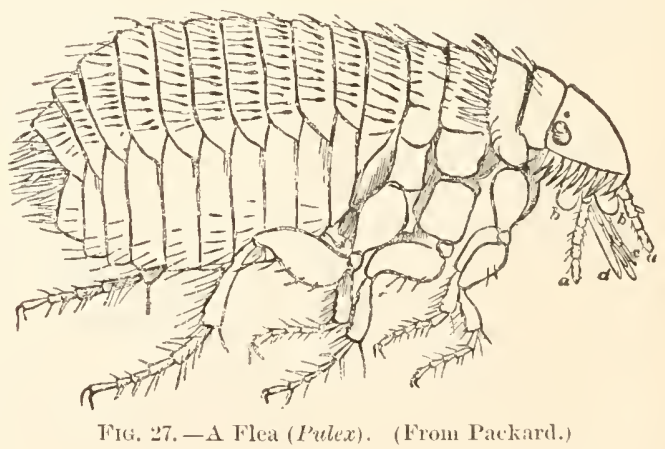
influenor of the chase after harger animals, there is no ond-be he never so hmmble-who may not indulge in the lunt aftre this smaller game! In place of wings the flea has four small, sealy plates. The minute agses-about a dozen to each female-are laid in obsenre places. such as the rracks of a floor, the hair of rugs, etr., ancl the larva is wormlike and feeds mon whatevor animal matter-as grease and blood-or cleaving vegetable matter it can find. 


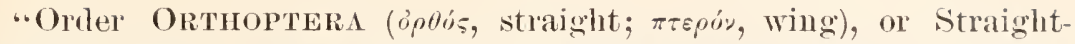
winged Insects. Characterized by having the front wings (called

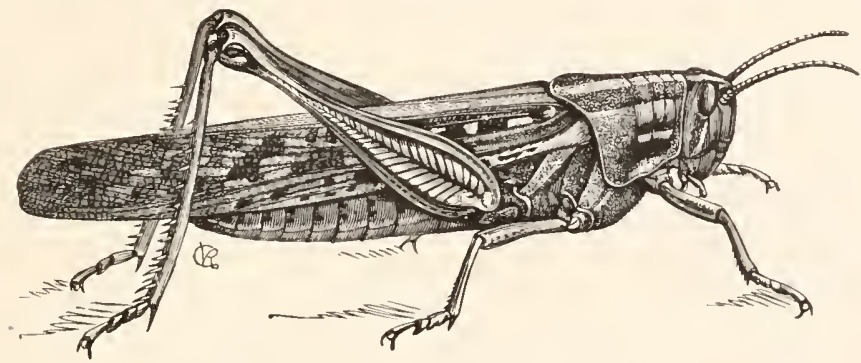

FIG. 28.-D Locust (Acrideum americamum).

tegmina) straight amd usually narrow, pergameneons or parehment-like, thickly veined, and overlapping at tips when closed; the hind wings large and folding longitudinally like a fan. Transformations incomplete.

"The insects of this order" lave a lengthened body and very robnst jaws, with a correspondingly large head. The legs are strong, and fashioner either for grasping, rumning, climbing, jnmping, or burrowing. As in the other orders, where the transformations are

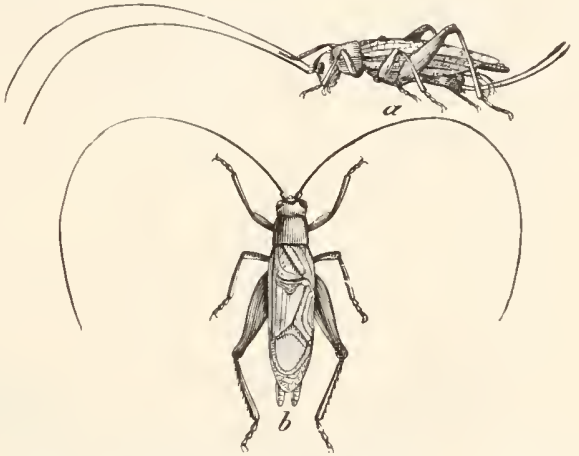

Fig. 29.-A Tree-cricket (Ocharis saltator), a, female; b. male. ineomplete, the young differ little fom the parent, except in the want of wings: and in many instances even this difference does not rxist, as

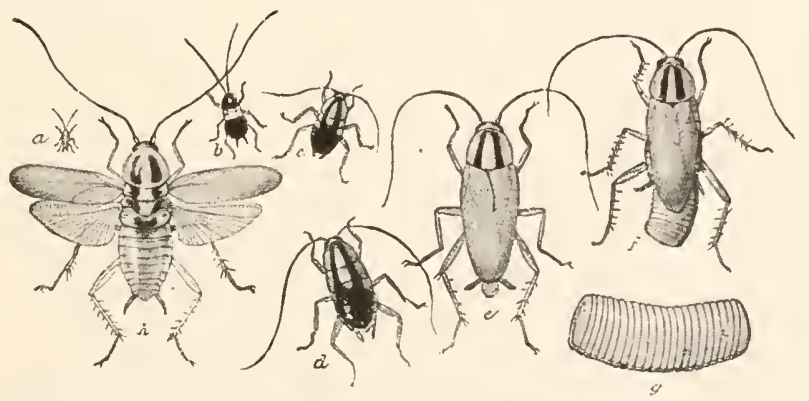

FIG. 30,-The Croton Bug or German Cockroach (Phyllodromia germanica.) $a$. first stago: $b$, second stage; $c$, third stage; $d$, fourth stage; $c$, aduit ; $f$, adult female with egg-calse; $y$, egg-case-enlarged; $h$, adult with wings spreat-all natural size except $g$.

there are numerons species which never aequire wings. There are no aquatic Orthoptera. Some are omnirorous, ofhers rarnivorons, but 
most of them herbivorons. They form four distinet sections: 1st,

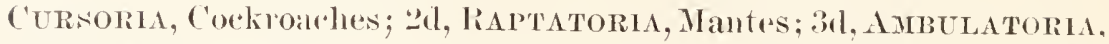
Walking-sticks; 4th, SALTATORIA, ('rickets, Grasshoplers, and Locusts.

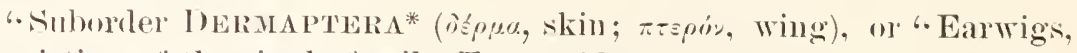
consisting of the single family Forficulide, which may be placed with

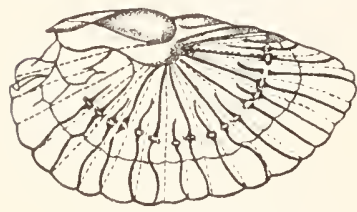

Frt. 31.-Hind wing of Earwig. (From Comstock.) the Orthoptera. They are rare insects with ns, but very common in Enrope, where there prevails a superstition that they get into the ear and canse all sorts of trouble. The front wings are small and leathery; the hind ones have the form of a quadrant. and look like a fan when openerl: and the characteristic feature is a pair of forceps-like appendiages at the end of the body, best developed in the males. They are nocturnal in habit, hiding during the diy in any available recess. The female lays her eggs in the gromol, and singularly enough, broots over

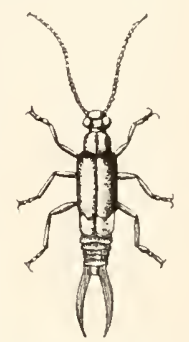

F1G.32.-An Ear. wig. (Froul Packard.) them and over her yomg, the latter crowding moler her like chicks meler a lieni."

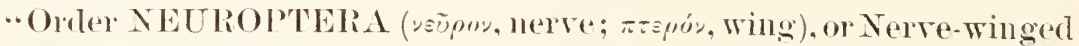
insects. Characterized by having the wings reticulate with numerons

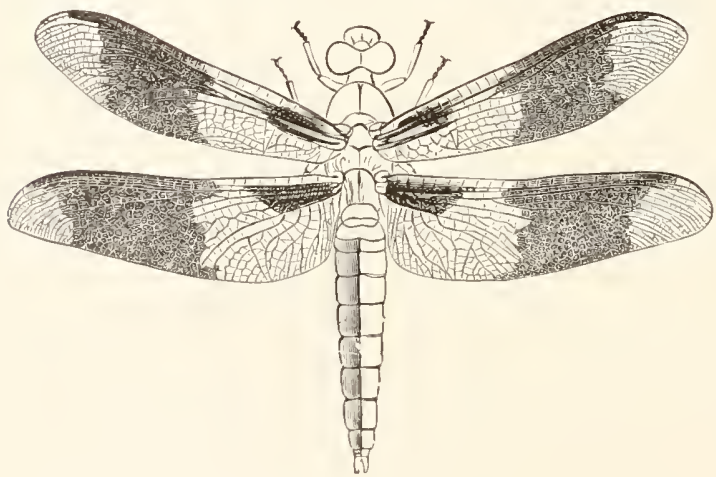

Fig. 33.-A Dragm-Hy (Libellule trimaeulata), (From Packard.) veins so ats to look like net-work. The order forms two natmal divisions, the first incinding all those which molergo al complete, and the see. ond, called Psendo-nen. roptera (Dictyotoptera, Burmeister), those which undergo :m incomplete metamorphosis. * * * The insects of this order are, ats a whole, more lowly organized, and more generally alpatic, than either of the others. A

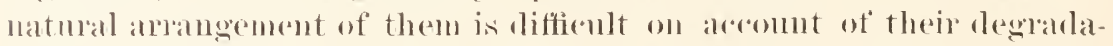
tional chanater. They present forms which are syonthetic and clesely approateh the other order's, amd the evolutionist maturally looks mon them as furnishing an ideal of what the ardhetypal forms of om present inserets may have been. They ane, as a rule, lange and sluggish. with

Emplexoptera of some anthors from $\varepsilon v$. Well; $\pi \lambda \dot{c} \gamma(u$, folded, refterring to the folded wings. 
the borly parts soft and little spedialized, and the muscles weak. Their remains are fomml in the Deronian and Carboniferoms deposits.

-They are mostly ranivorons, and with the exception of the Whiteants and rertain Book-lice they none of them affect man injurionsle, while sonte are quite beneficial."

The first division of this order, or the Nemroptera proper, chanacterized by having incomplete metamorphoses, may be considered muler the three following suborders:

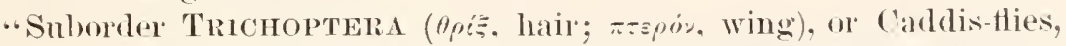
containing the single family Phryganeidae, and plared with the Neuroptera, thongh bearing great affinities with the Lepidoptera. Every good disciple of Walton and lover of the "gentle att" knows the value of the Caddis-fly, or Water-moth, as bait. These fliss very molh resemble reptain small moths, the scales on the wings of the latter being replaced in the former with simple hairs. The larve live in the water
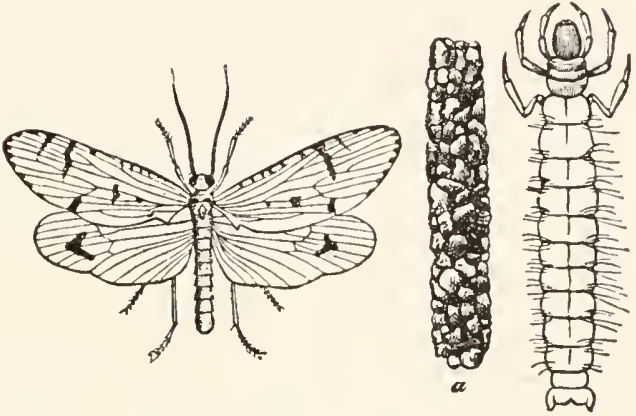

Fig. 34.-Caddis-fly, larra and its case. (From Jackard.) and inhabit silken eases, which are nstually "ylindrical and eovered witl vallious substances, alecorling to the species. or the material most comveniently obtained by the imbividual."

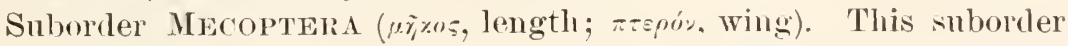
inclurles a peculiar gromp of inserts, the most striking characteristics of which are the month-parts, which are pro-

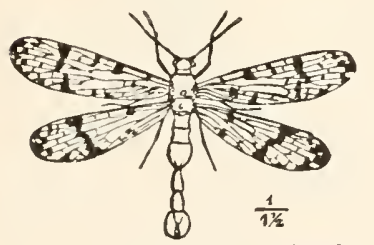

Fig. 35,-Panorpat or Scorpion-fly. (From Packaril.) longed into a rostrum or beak. The wings are long and narrow, and of nearly equal size. The abdomen of the male is ronstricted near its posterior end and terminates in long clasping organs from which these insects obtain the common name of Scorpion-flies.

The larvac of one gemus (P'anorpa) are remarkable for their great resemblance to the larva of Lepidoptera. They have, howerer, cight pairs of abdominal legs. The haloits of these inserts are not well known. Wut they are supposed to he gencrally predaceous.

Suborder Netrop'teri. This gromp as restrinted by modem anthors is a smail one. including the largest species, as in the lFellgrammite, the Lare-wing Flies, the Ant-lioms, and the Mantispas representing the tamilies, sialida and Hemerobida, with their subtamilies. The finst includes the so-ealled Hellgrammite Fly (Corydalus cormutus), one 
of our largest and most striking insects, the larvie of which is known as Dobsonsby anglers, and is aquatic and earnivorous in habit. The Heme-

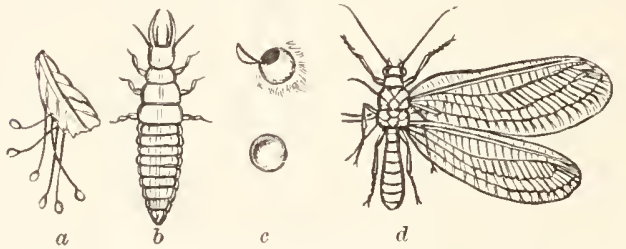

FIG. 36.-Laee.wing fly. $a$, eggs, $b$, larva, $c$, rocoons, $d$, fly with left wings removed.

robiidie is a large family, comprising, as a rule, delicate insects with rather ample ganzy wings. The larve are predaceons. The common Lace-wing flies are anong our most beneficial inserts, destroying plant-lice and other soft-borlied species. To the same ramily belongs the Ant-lion (Hyrmeleom), the larvat of which have the eurions habit of constructing a funnel-shapel burrow in the sand, in the bottom of which they conceal themselves and wait for any soft-bodied insects which may fall into the trap. This fam-

ily also includes the

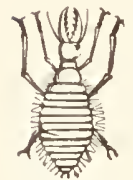

Fig. 38.Myrmeleon ]arva.

peculiar Mantis-like insects belonging to the

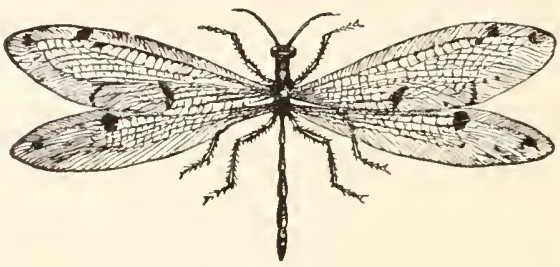

Fic. 37.-An Ant-lion (Myrmeleon). (From l'ackard.) genus Muntispu. As in the true Mantis, the prothorax of these insects is greatly elongated and the first pair of legs are fitted for grasping. The larve are parasitic in the ega-sacs of certain large spiclers (genera Licosa, Dolomedes, ete.), and undergo a remarkable change in form after the first molt. In the first stage the larva are very agile, with slender bodies and long legs. After molting the body becomes much swollen and the legs are mnch shortened, as are also the antennie, the

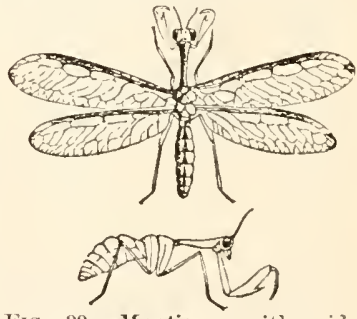
Fig. 39.-Mantispa with side view beneath. (From l'ackard.) head becoming small and the general appearance reminding one of the larva of a bee.

The second sretion of the Neuroptera, characterizerl by complete metamol'phosis, comprises the following suborders:

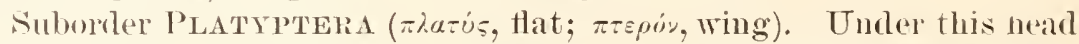
are grouped the White-ants (Termitide), the Bird-lice (Mullophaye), and the Book-mites (Psocide). The suborder receives its name from the fact that in the ease of the winged forms the wings, when at rest, are nsmally laid flat upon the back of the insect. The Mallophagal, on Bird-lice, are degraded wingless inseets, and are parasitir chictly on birds, but also on mammals. In shape of body and ehatrateter of the month-parts they are most nearly allierl to the Psordide. The latter fimily includes both winged and wingless forms, the Book-mites belonging to the latter category. The winged forms may be illustrated 
by the common species, Psocus renosus (see Fig. 40). The legis and antemine are long and slender and the wings are folded roof-like orel the boty when the insect is at rest. They feed on lichens and dry regetation.

The Termitidie are represented in this comntry by the White-ant (Termes flaripes), which is frequently so destructive to woodwork, books, ete. The term White-ant al, plied to these insects in mufortmuate, as in structure they are widely separated from ants antl resemble them only in general appearance and also in their social habits. Like the ants they live in colonies and have

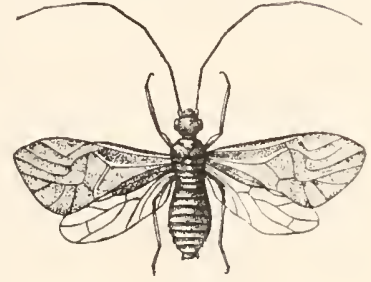

Fig. 40.-I'soeus venosus. (From Comstock.) a number of distinct forms, as winged and wingless. males and females, and workers and soldiers.

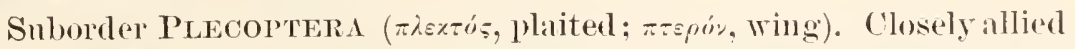
to the latter suborter is the suborder Plecoptera, which includes the

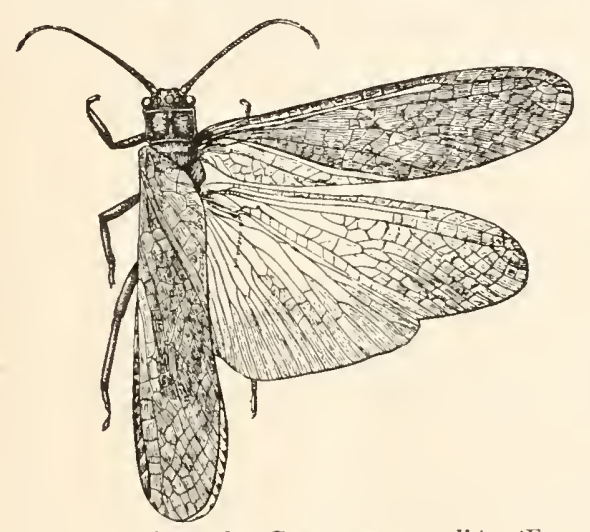

FIG. 41.-A Stone-fly (Pteronarcys regalis). (From Constock.) single family Perlidie or Stoneflies. The larvae and pupte of these insects are aquatic, lring often found muler stones in watel, whence the name. The adnlts are long, Hattenes insects, with long antemine. The wings are ample and are somewhat folded or plaited, from which character the suborder takes its name.

Suborkler Odonata (mituses, tooth). This includes the Dragon-flies or Libellulislas, the most common and the best known of the Nemoptera. The larva and the active pupa or nymplu are aquatic and are predaceons, as is also the adult. A common species is represented at Fig. 33.

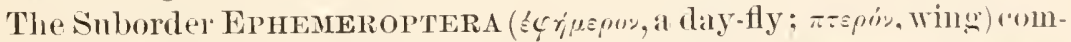
prises the May-flies, or Ephemeriule (see Fig. 42). These insects are very fragile and are often attracted in enormons numbers to electric lights. They have large foont wings, while the hind wings are small, rudimentary, or wanting. They are furnished with two or three very long, jointed, theadlike candal appendages. The larval and nymphal stages are passed in the water and aquatic vegetation furnishes the food, althongh some species maty be predaceons. The adults have very rulimentary

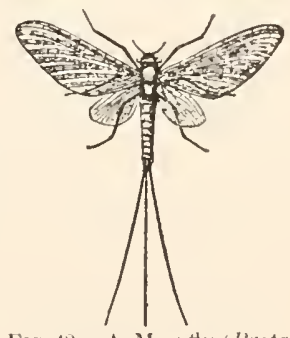

Fig. 42.- I May-Hy (l'rota manthus maryinatus). (From l'ackard.) 
months and eat nothing; their term of life is also very limiten, not exrealing: $2-4$ days.

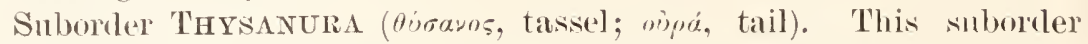
comprises binute, degladed insects commonly known as spring-tails,

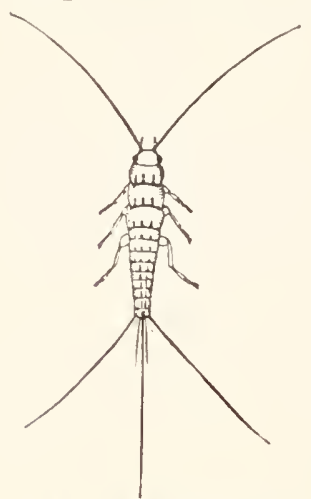

FIt. 4:- Lepisma 4-seriata). (Atter Packard.)

Bristle-tails, Fish-moths, Snow-tleas, ete. 'They oecur in damp situations and also infest books, wall-paper, ete., eating the stareh paste in the book-hindings, or beneath the wall paper. They comprise very primitive forms and are interesting becanse they are supposed to represent the original stock from which the higher orders of insects have sprumg. They are wingless. usually with simple eyes, and clothed with scales, and mudergo no metamorphosis. Some of them, as the Fish-moth (Lepisma sp.), rum very rapidly and are furnished at the end of the body with a number of long bristles. In other forms these anal bristles or stylets are mnited at the hase aml bent moler the body and become a powriful jumping organ, giving them the very appropriate nane of spring-tails.

\section{COLLECTING.}

Generat Considerations.—"Fur departments of matural history offer greater inducements or facilities to the student than Entomology. He need not pass his threshold for material, for it may be fonnd on erery hand and at all seasons. The directions for collecting, preserving, and studying insects might be extended indefinitely in detail, as volumes have alrealy been written on the subject; but the more general and important instructions are soon given.

- Begimers are very apt to supply themselves with all sorts of alpliances advertised by matural history furnishing stores. Many of these appliances, when it comes to real, practical field-work, are soon abandomed as nseless incumbrances: and the greater the experience, the simpler will be the paraphermalia. My own equipment, on a collecting trip, consists chiefly of a cotton umbrella, a strong and narrow steel trowel or digger, a haversack slumg across the shoulders, a cigar box lined with sheet rork, and a small knapsack attached to a waistbelt whicll girts a coat, not of many colors, but of many pockets, so made that in stooping mothing falls out of them. Thr monlolla is one of the indispensables. It shields, when necessary, from old sol's scorching rays and form the pelting, drenching storm; brings within reach, by its looked handle, many a larva-freighted bough which wonld otherwise remain nu. disturberl; and forms an exeellent receptarle for all insects that may be dislorged fom bush or hranch. Opened and held inverted under a boum with the loft hame, while the light manipulates a beating-stick, ent for theoreasion, it will be the recipient of many a choice specinen that would 
nerer have been espier amid its protective smrommlings. Some collectors nse an umbrella painted or lined on the inside with white, to fareilitate the detection of any object that drops into it; but as there are fully as many, if not more, pale and white insects as there are dark or blark ones, the common darte nmbrella is good enough for all ordinary pmpposes; and if any improvement on the ordinary cotton nmbrella is desirred, it shomld be in the way of a joint of knurlie about the middle of the liandle, whirh will facilitate its packing and using. The trowel is valuable for prying off the loosened bark flom old trees, whether felled or standing. and for digging into the gromm or into deeaying stumps and logs. The haversack is for the earriage of different kinds of boxes (those made of tin being best) intended for larval and other forms which it is necessary to bring home alive for loreeding purposes; ant if made with a partition so that the filled and empty boxes may be separated, all the better: it may also be used for nets aud other apparatus to be mentioned, and for sareh provender as is necessary on the trip. The knapsick may be made on the plan of a eartridge box, of stont canvasor leather, and shonld be of moderate size and shmgonto the belt so as to be slipped to any part of the waist and not hinder free bod. ily motion. It may be used to earry bottles, phials, and other small appliances, and should be accoldingly partitioned and furnished with loops or poekets on the inside. The cigar-box is for the reception of pinmed specimens, and may be slipped onto the belt, of buttoned to the tromsers by means of leather.

"The greatest requisites in collecting ar" a pair of sharp eyes and

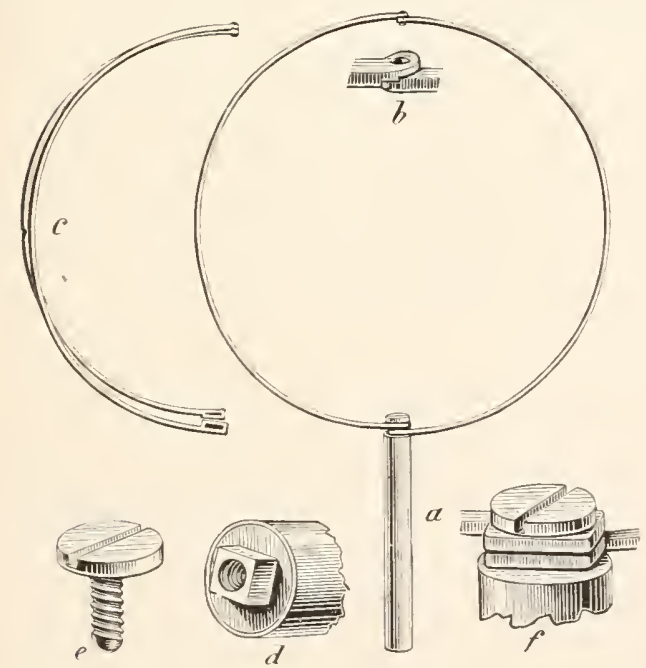

Fig. 44.-The Butterfy net-frame. ready hambls, with roolness and self-possession; but a few traps will materially aid. One of the most inportant is the hamr-net, which may be made so as to subserve the two purposes of a sweeping and an air-net."

"The fiame of the net which I use is illustrated herewith (Fig. 44), and will be fonnd strong and serviceable and conveniently portable. It is construrted as follows: Take two pieces of stont brass wile, each abont ¿0 inches long; bend them half-circulatrly and at ons end by a folding hinge having a rheck on one sicte, $b$.

The other ends are bent and beaten into two squale sorkets, f, which fit to a nut sunk and soldered into one end of a blass tube, d. Wrien 
so fitted. they are secured by a large-headed serew,e, theaded to fit into the unt-socket, and with a groove wide emough to receive the back of a common pocket-knife blade. The wire hoop is easily detached and folded, as at $c$, for convenient carriage; and the handle may be made of any desired length by cutting a stick and fitting it into the hollow tube a, which should be about 6 inches long. It is well to have two separate hoops, one of lighter wire, furnished with silk gauze or some other light matrerial, for catching flying inserts, and one which is stouter and furnished with a net of strouger material for sweeping non-flying specimens.

"Another still more simple, bnt less convenient frame, is thus described by my fiend F. G. Sanborn, of Boston, Mass.:

'Make a loop of strong iron or brass wire, of about 3-16ths of an inch in thickness, so that the diameter of the loop or circle will not exceed 12
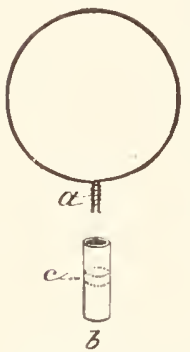

Fis, 45.-The Sanborn netframe. inches, leaving an inch to an inch and a half of wire at (ach ent bent at nearly right angles. Bind the two extrenities of the wire together with smaller wire (Fig. 45, “), and tin them by applying a drop of muriate of zinc, then holding it in the fire or over a gas Hame until nearly red lot, when a few grains of blork tin or soft solder placed upon them will flow evenly over the whole surface and join them firmly together. Take a Maynard rifle eartridge tube, or other brass tube of similar dimensions; if the former, file off the closed end or perforate it for the admission of the wire, and having timned it in the same mamner on the inside, push a tight-fitting cork half way through (Fig.c) and pour into it melted tin or sott solder, and insert the wires; if carefully done, you will have a firmly constructed and very durable foumdation for a collecting net. 'The cork being extracted will leave a convenient socket for inserting a stirk or walking cane to serve as a handle.'

"My fiemd, J. A. Lintner, of Albany, N. Y., makes rery good use, in his ordinary promenades, of a telescopic fish-rod, with a head (Fig. 46) screwed on to one end, in which to fasten an elastic brass coil on which the net is di:arm, but which when not in use sits smugly inside his silk lat.

"The bag shomld taper to the bottom, and in auy case its length shomld be fully twice the diameter of the hoop, so that by giving the net a twist, the mouth may be closed and the contents thus secured. The sweeping-net maty he poterted aromel the hoop with lather, and in use shonld be liept in a steady and continned hack-and-forth notion, over and tonching the plants, nutil the contruts are to be examinod; whin, by placing the hearl at the olenimg and quietly surveying the restless inmates, the drislerata may be seenred and the rest turned out. A smolen dash of the air-net will usually lay any flyingolgect at the bottom. A net for aquatic insects may be mate on the sane principle, but should be stont, with the

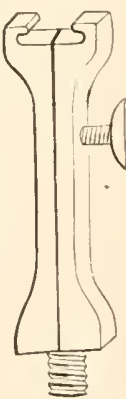

FIG. 46 . Clamp of the Lint. ner net. meshes open enough to allow free bassace of water, and the bag mot yuite 
as deep as the diameter of the hoop. A forceps net, which consists of two gauze or bobbinet eovered frames, having riveted handles, so as to close like a pair of scissors, is employed for small insects; but I find little use for it. A coarse sieve, together with a white towel or sheet, will be found of great service for special oecasions, particularly in the spring, when the seareh for minute insects found moler old leares, or for pupe arouml the butts of trees, is contemplated. With the sheet spread on the gromul, and a few handfuls of leaves and leafy mold sifterl over it, many a minnte specimen will be separated from the coarser particles and dhop to the sheet, where the eye may readily detect it. Conversely, the earth taken from around trees may be sifted so as to leave in the sieve such larger objects as pulse, ete. Another favorite plan, with some collectors, of obtaining specimens, especially night-flying moths, is by 'sllgaring.' This consists of applying to the trunks of trees $\mathrm{or}^{\prime}$ to strips of eloth attached to the trees some sweet, attractive, and stupefying preparation. Diluted molasses or dissolved brown sugar, mixed with rmm on beer, is most frernently employed. I have found sugaring of little use till after the blossoming season, and it is almost impossible to so stupefy or intoxicate an insect that it will remain upon the sugared tree till the next morning. I generally sugar at eve, and visit the tree sereral times between sumdown and midnight, armed with wide-mouthed killing-bottles and accompanierl by a second person, who carries a dark-lantern. Isolated trees, on the erlges of woods, gire the best results. Everybody lnows how some poor moths will persist in flitting around a light until they singe their wings: and, as many inserts are strongly attracted to bright artificial light, it may be employed with good results, especially during warm and damp evenings. The collector should never go unprovided with a small box or tube full of different sized pins (a corked cartridge-tube makes a good box, a pair or two of forceps, a pair of scissors, a little mncilage, and the killing apparatus to be described."

With these general remarks, it will be well to consider some of the important paraphernalia more in detail.

COLLECTING APPARATUS.

The Sreeping Net.-A inultitude of insects of all orders feed or rest on grasses and other low plants. Unon elose inspertion of these plants a careful observer will be able to secure, without any instruments, not only many mature inserts. but also many larvae in connection with their food-plants. This is laborions and slow work, only neeessiry on special oreasions. The beating net, which is constructed on the same general plan as the butterfly net, is valuable here as a time saver. By holding the handle of the net firmly in one hand and quickly sweeping orer the plants first from right to left, and then, after quickli turning the net again, sweeping trom left to right, most insects coming within reach of the sweep will fall into the bag and may be easily taken 
out and put into the collecting-vials. From this morle of operation it is evident that the sweeping net must he stronger in all its parts than the butterty net, but otherwise it maly be made on the same plan.
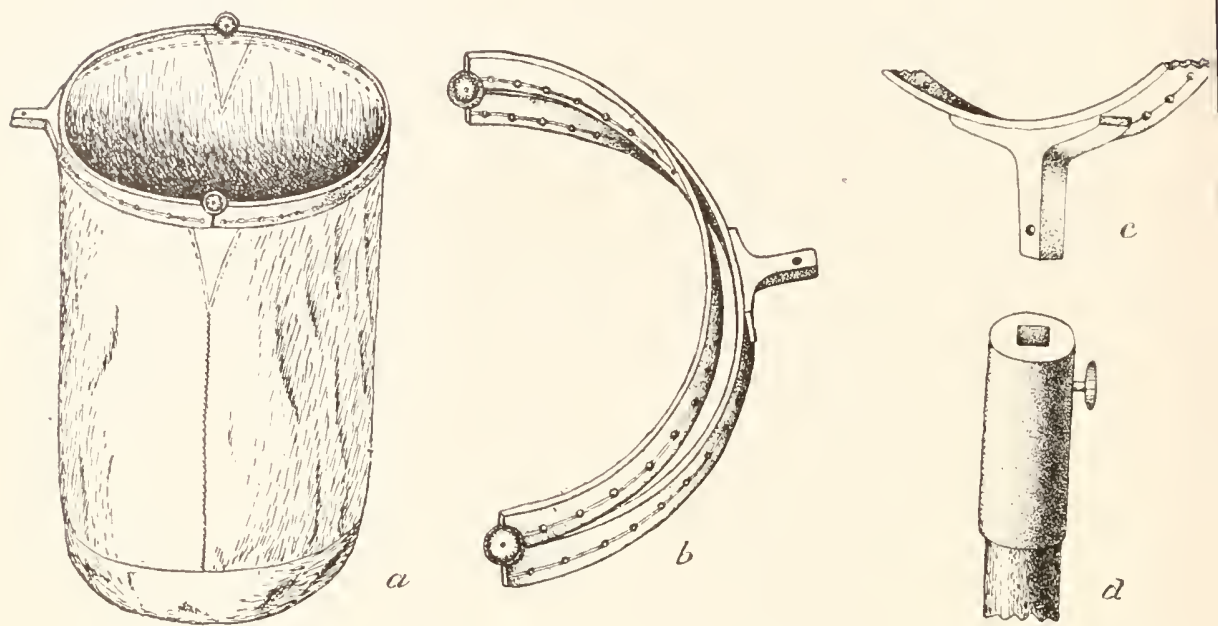

Frg. 47.-The Derrolle Sweeping Net. $a$, net entire; $b$, frame; $c$ and $d$, attachment of frame and handle (original).

The ring should be rigid, made of brass or iron, either of one piece of of two pieces, and fastened to the hamble or stick in the same way as the butterfly net. The bag need not be as longas in the butterty net, about 18 inches being sufficient, but it should bo of stont cotton ar linen and the bottom should preferably be sewed in as a loumd piece, so as to aroid corners. Care needs to be bestowed on the fastening of the loag on the ring, for by the use of the net the part of the bag sewerl aromel the ring is soon rohafed through. To prevent this a strip of leather is sewed over the cotton alomg the rim, but since even this must bo fieynently renewed some other devices are used to give greater durability to the net. In the pattern of a beating-net originally sold by Deyrolle in Paris, the metal ring was fiattened, with the narrow elge pointing mprads and the broad side pierced with holes at suitable intervals and srooved on the onter surfice between the holes. The bag is sewed on to the inner side of the ring by stont twine, which passes form one hole to the next and is thus prevented fiom coming in contact with obstructive ohjerts, and only the botton of the bag wears and will need to le oceasionally mended or renewed.

Another method of preventing the tearing of the upper rim of the bag is described and illustrated in Kiesenwetter's useful volume " 1 ) Naturaliensammler" from which I shall frequently have oreassion to quote. In this net the main ring is of romeled inom wire on which a mumber of brass rings are slippod. 'These must he but little larger 
than the diameter of the wire. These little brass rings should not be more than $30 \mathrm{~mm}$. or at most $40 \mathrm{~mm}$., distant from each other. and to them the mper rim of the bag is sewed with very strong twine and is thus protected from wear and tear. The handle or stick of thenet should be firmly and solidly attached to the ring and should be stout and not liable to break. I prefer a rather short stick, say not longer than two feet.

I figure herewith the ring of a very convenient net for sweeping or beating purposes. It has the advantage of being for sale on the market, and

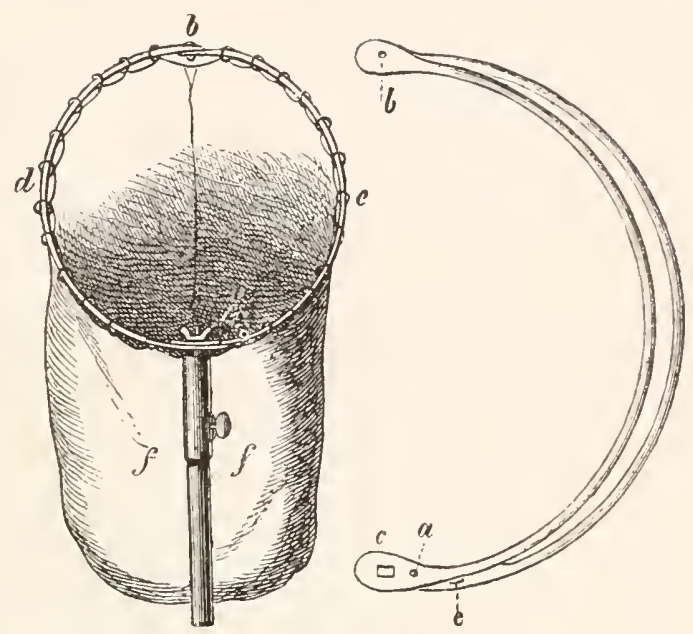

FIg. 48.-Beating net, opened and attached to handle, with frame of same folded. (After Kiesenwetter.)

in fact is an ordinary fishing dip net of small size. It is hinged in three places, as shown in the figmre, and folds into very small compass.

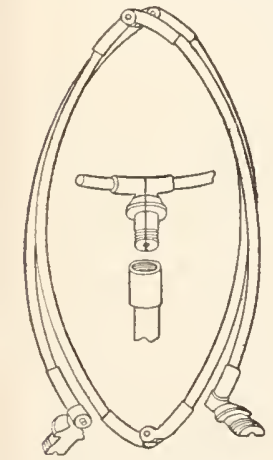

Fig. 49.-Folding ring for beating net (original).

Wheu unfolded and brought together, it screws into a ferrule which maly be attached to a wane or a special handle.

The beating net can be sucessfully used at almost every season of the year. Even on warm days in winter time many specimens can be swept from the dead grass. So long as the dew is on the plants or in rainy weather no beating should be attempted, as the more delieate species are more or less spoiled by the moisture. After one or two mimutes' sweeping the contents should be examined. Those insects which are quick to take wing or which are good runners should first receive attention: the less active ean then be exanined more at leisure. The desiderata are then disposed of, the rest thrown away, and the beating renewed.

The beating net is an important instrument for collecting all inscets excepting mature Lepidoptera, which are apt to get rubbed. Iany larve, especially of Lepidoptera, are caught by beating and are mostly in good condition, but it is usually diffecult to ascertain the food plant.

The ITater Net.-The numeroms insects or insect larva which live in the water can not be conveniently collerted without the use of a net, except where they live in small shallow streams or creeks with 
gravelly or stony bottoms. A suitable water net ean readily be male by nsing the frame of the beating net and attaching to it a rather short bag of some coarse material, e. \%., "glass cloth," coarse millinet.

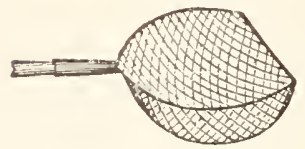

FI(i. 50.-The Water Net. (After Packard.)

The mode of operation with this net is very sim ple: if some insect is seen swimming in the water, the net is carefully brought beneath the speeimen, which is thus lifted out of the water. Most water inserts are, however, not seen swimming about freely, but hide amid the various plants, mosses, ete., or in the mud at the base of the plants, and they wan best be captured by dragging the net through these plants. When taken from the water the net is more or less filled with mud and parts of plants, and the water must be allowed to roun ont and the contents of the net spread ont on a cloth or on a flat stone, if surh be at laare. Thre insects are at first not readily seen, but after" a short while they begin to emerge from the mul and crawl about, and can readly be taken np with a finceps.

Irater Dip Yet.-The small water sieve, shown in the acomplanying illustration (Fig. 51), and somewhat remenbling in appearance a joekey cap, is frequently of service in collecting the larvae of aquatic inserts, especially where it is necessary to serape

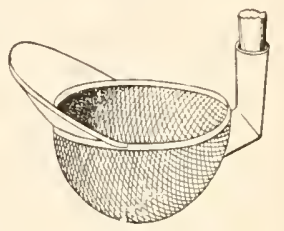

Fig. 51.—inall Water Dip Net (origina1).

subnerged stones or timbers. In use it is fastened on the end of a eane or stick, and can be easily made by any tinsunith.

The Imbrella.-The umbrella, as already stated, is one of the most useful instruments of the collector, since it enables him to obtain all those mumerons insects which live on the branches of trees, on shrubs, and on other large plants. A common stout cotton umbrella is sufficiently large, but is liable to gat out of joint, and morenver the specimens hicle themselves under the ribs. It is well, therefore, to have the inside of such umbrella lined along the ribs with muslin, or some other Inaterial. preferably of a light eolor. An umbrella specially construeted for untonological purposes is offered for sale by E. Deyrolle, in Paris. It resembles a stoutly built common umbrela, but has the inside lined with white linen and the haudle has a joint near the middle, so that the umbrella can be nore conveniently liedd and more readily parked anay. The opened and inverted umbrella is held with the left hand moler the loranch which the collector intends to relieve of its entonological inhabitants, while the right hand, armed with a heary stirk, is free to properly jar the branch. Care must be taken in the jarring, lest the inserts are knocked beyond the cireumference of the umbrella. The larger the umbrella the greater are the chances of maling rich captures, but the more difficult it becomes to manipulate, esperially where the wools ane dense or where there are many vines, ete. In the absence of an umberla the butterfly net or the beating net can be used. 
A drawback to collecting with the mmbrella is that many insects take wing and escape before being seetured. This can hardly be aroided,

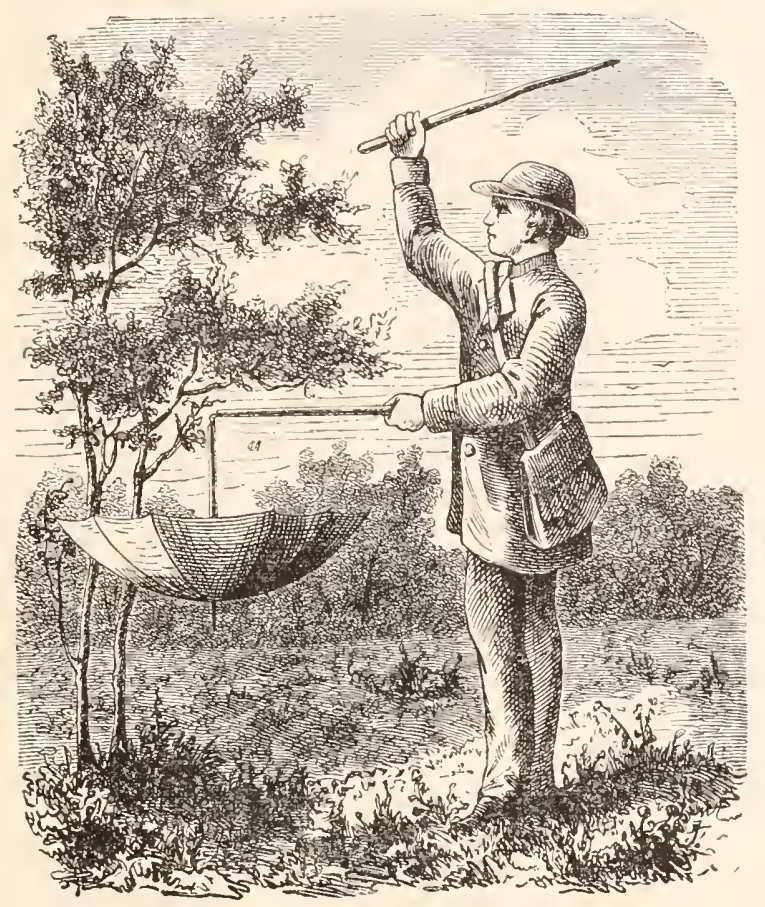

FIG, 52.-The Umbrella and its mode of use. (After Kiesenwetter.)

and experiencerl collectors, in sonthern rountries more particularly, have foum it advisable to discard the mubrella and to nse in its stead a very large butterfly net, 2 feet or more in dianeter.

The Beuting Cloth.-A rery simple substitute for the umbrella, and one which can always be rarried withont inconvenience, may here be lescribed. It consists of a piece of common unbleached cotton cloth (1 yard scruare), to each comer of which a loop of stont twine is sewed. Epon reaching the woods, two straight sticks, each about 5 feet in length and not too heavy, but also not so small as to be liable to lneak or to bend too easily, are ent from a convenient bush. The sticks are phaced crosswise over the cloth and fastened to the loops at the fon ends. This is easily and quickly done by making slicling loops of the simple loops. The eloth is thus kept sprearl ont between the sticks, and forms a very good substitute for an umbrella. In beating, the sticks are held at their intersecting points. When not in use one of the loojs is detanhed from the stick and the instrmuent "an be rolled "1) and carried under one arm withont serionsly interfering with other operations of the collector. When laid on the glomul, with the sticks on the molerside, this simple instrument may be arlvantageonsly used $2506-3$ 
as a "loth on which to sift or examine fungi, moss, pieces of bark, etc., and since the cloth is always tightly expanderl, it offers a smooth and level surface, where examination of varions ol,jects can be made with ease and aceuracy.
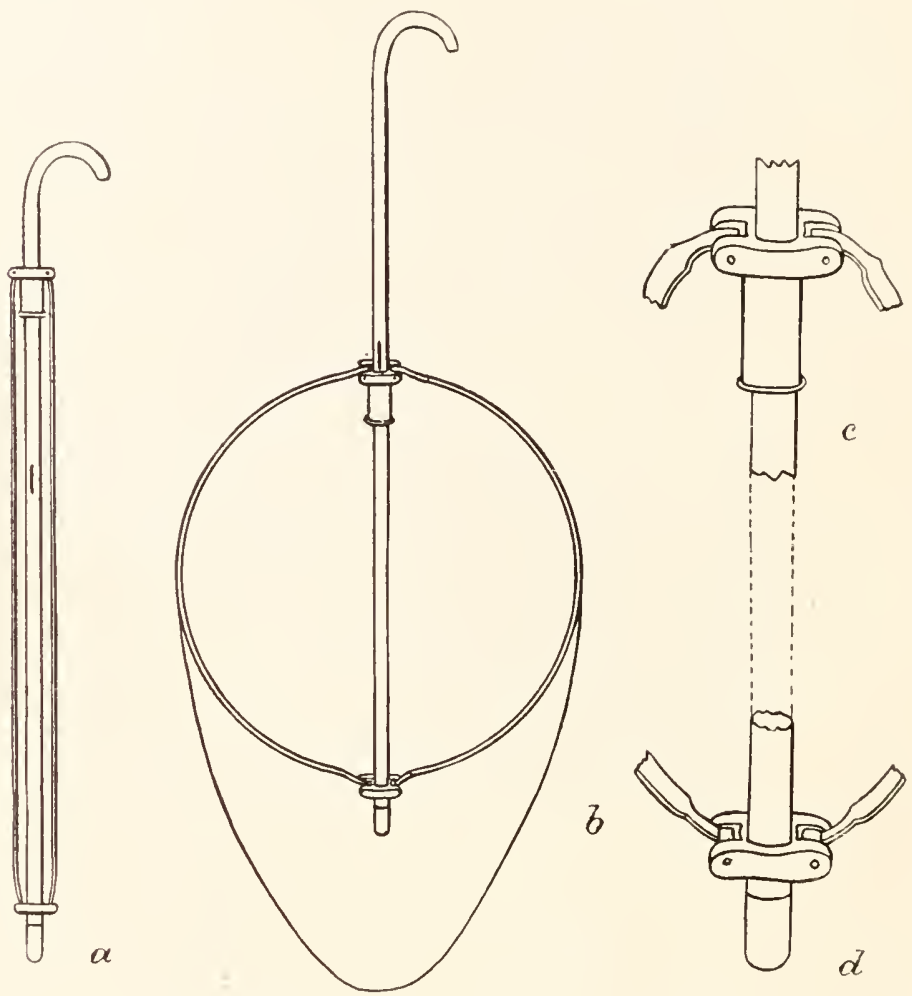

Fig. 53.-The umbrella leating and sweeping net (original).

The C'mbrelln Vet.-A very anvenient form of net for both sweeping and for nse in place of an umbrella for heating las been devised by I)r. (George Marx. (See Fig. 53.) It is constructed from an old unbrella, as follows: To the handle of the umbella are attached two steel rods working on hinges at the apex of the mubrella, as do the ordinary mulnella ribs, and attached to the sliding piece of the mombella in the same mammer, as shown at $a$. These rods shonld be ahont 2.2 feet long. When the sliding piece is pushed up and anght behind the spring clip, as shown at b, a cirenlar loop is formed giving the framework for the net. The latter, which shonld be comparatively shallow, is made of stont muslin and sewed to the frame, as in the ordinary strexping net. The enlarged dhawings a and d illustrate clearly the manner of "onstructing the frame. The adrantage of this net is its convenience in carrying and its general usefulness, taking the plare of both the numbella and the sweeping net. When not in use the frame is 
allowed to assme the position shown at $\mathrm{A}$, and the net may be waipled abont the frame and the whole inserted in an ordinary nubrella arere

The Niere.-This useful aid to good rollecting has not been genelally amployed by American entomologists. It facilitates the finding of small insects living muder old leaves, in moss, in decayed trees, in fingi, in ants' nests, or in the ground. Any ordinary sieve abont a foot in dianeter and with meshes of abont one-tiftl of an inch will answer. thomgh for durability and convenience of "arriage one made of two wire or brass rings and muslin (Fig. 54), as follows, is the best. The emols of the wire netting shonld be bent aromel the ring so as not to project. A piere of common muslin abont 1 toot wide and lomg enongh to go aromed the ciremuference of one of the lings is then sewed together so as to form a kind of cylinder or bag without bottom, and the nypel and lower rims of this bag are then sewed on around the two rings. The whole instrument thus forms a bag, the top of which is liept open by the simple wire ring, and the bottom is closed by the second ring covered with the wire netting. Ifter cloosing a suitable locality a white cloth is spread as evenly as possible 61 the ground;

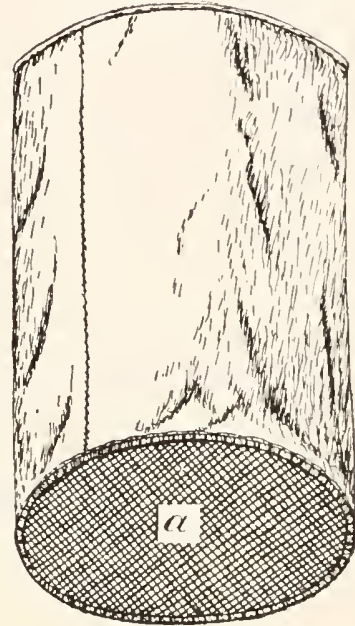

Fig. 54.-The sieve. $a$, wirentting (original). the collector then takes the sieve, places therein two or three hambliuls of the material to be sitted, returns to his cloth, and, holding with his right hand the lower ring and with the left hand the mpere ring, shakes the sieve over the cloth. The larear particles and specimens are retained in the sieve while the smaller fall through the meshes on to the rloth. Care must be taken that the siftings form an even and thin layer on the surfice of the cloth, so as to be easily examined from time to time. If the locality is favorable many insects will be seen at the tirst glance clawliug or rumning about, and these can easily be pirked 11) by means of a moistemed brush, or with the forcejs. Many other insects, lowever, either feign death or, at any rate, lo not move mutil after the lapse of several mimtes, and the proper investigation of a single sifting often wepuires mmeh time, and patience will be mone fully lewarled here than in any other mode of collecting.

The size of the wire meshes given above is best arlapted for sifting the fragments of old decayed trees. which fimmish the most frecprent material for the use of the sieve, hut for sifting ants nests, soil, atc.. a sieve with smaller meshes is desiluble.

The sieve is indispensable to the Coleopterist, the Arachnologist, and to the specialist in the smaller Hemiptera and Hymonoptera, but it is also useful for most other orders, many interesting speries existing which ean be seroned in numbers only by this mode of collecting. Many 
Tineida and even Noctuidie hide muler old leares, but the specimens are usmally rubbed and rentered nseless in the process of siftmg. Many larvie and pupe can, however, thus be obtained.

If the locality chosen for sifting prove to be a good one, it pays to put the sifted material in a small sack and to carry it home where it can he investigated at leisure, and with a greater thoroughness than is usually jossible ontrloors. This sack ran be easily arranged to be attacherl to or drawn orer the lower ring of the sieve, so that the sifting can be done directly into the sack.

As a rule it may be saisl that very dry places are least modnctive, while more or less moist places are apt to fumish a rich harvest. Old wot loaves lying immediately along the erlges of swamps, or wet moss, harbon many interesting inserts, hut snch wet material is sitted with difficulty.

The sieve "an be nserl with great arlvantage at all seasons of the year, but more especially late in fall or early in spring, when so many species are still hiberuatiog.

The Chisel.-For securing the many insects living or hiding nuder bark of dying un dead trees an instrment of some sort is indispensable, as, in most cases, the bark so firmly adlieres to the wood that it "amot be torn off" with the hand. A stont pocket-knife will do good service. but far loetter is a common chisel of medium size and with a short hamdle. This rhisel is also useful as an instrument tor digging in the gromer or for investigating the interior of partly deeayed logs.

The Trouel.-Asicle fiom the lact that many insects enter the gromul for the purpose of hibernation in varions stages, there is a rieh subterranean life to be found during the summer. There are many burowing Coleopitura; many, if not most, ants construct subterranean nests; the number of other fossorial Hymenoptera is very large, and there are also vallons burowing Orthoptera and many Lepidopteroms larvie which hide in the gromul during the day. Some instrument for digging in the ground is therefore of great importance, and while, ats stated above the chisel will answer this purpose if nothing alse be at hand, yet there are other instruments which perform the work much quicker and more thoroughly. The most available instrument is a rather small steel trowel, sncls as can he had at the hardware stores in a great variety of patterns, and which can be carried on exemrsions without murh inconvenience. One with a long and narrow blate, mate very stout. I have fombl very nseful, thongh somewhat awkard to (airry.

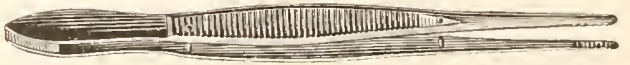

Lir. 5i. - The collecting tweezers.

The collecting Tuerars.-In the pieking up of specimens and transferring them into the varions bottles, vals, or boxes, the trained col- 
lector will gather hy hand the most delicate specinems without injuring them. Yet this labor will be sreatly facilitated by the use of the

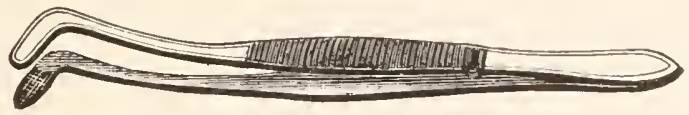

Fis. 56.- l'iming foreres.

tweezersor the brush. The former is a small. light pair of forceps, mate of steel or brass. It shonld be as pliable as possible, and the tip shomld be narrow and romnded off and not pointed. It may be either straight or eurved at tip, acoording to inclividual preference.

Snitable tweezers may be obtained at the larger hardware stores or of watchmakers. Excellent tweezers mate of steel (see Fig. in) ane

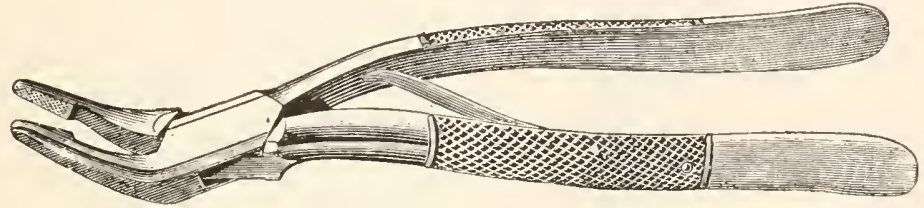

FIt. 57.-Pinning forceps.

soll for about 40 rents a pair by Codman, Shurtleff \& Co., Tremont street, Boston, Mass. Aside from their utility in picking up speeimens from the collect. ing cloth or the nmbrella. the tweezers are indispensable for extracting insects from cracks, or holes in timber, or from their burows in branclies and stems of plants, or from places whence it is impossible to dislodge them by hand. The

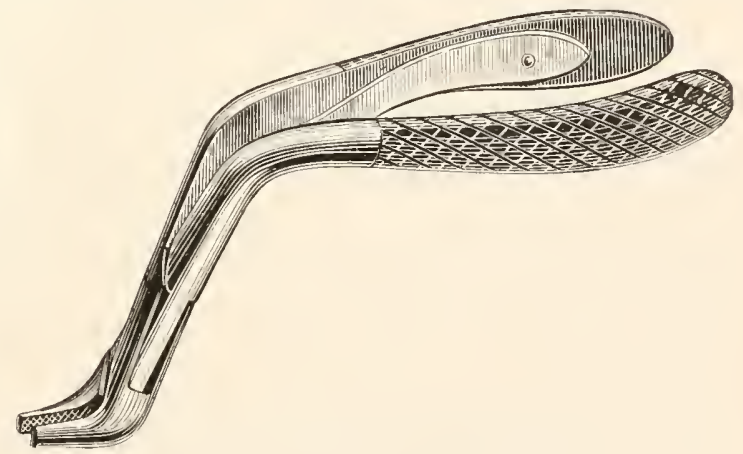

l'1, 5x.-l'inning forceps for Lepidoptera.

larger "collecting forceps," sold by vitrious dealers, to gond service in certain emergeneies, as when large scorpions or other very large and ferocious insects are to be secured.

For the handling of momted inseets various special forceps ance am ployed, a number of styles of which are shown at Figs. 5ti-S.

The Brush.-A common e'anel's hair brush, of smaller or latger size according to individual preference, is useful for picking up very sinall or soft-bodied insects. For this purpose the bus lo is slightly moistenerl with saliva, and the tip bromght in contact with the specimen, which 
then artheres to the brusle, so that it can readily and withont injury be transferred to the collecting bottle or box. The brush is indispensable also for preparing small speemens for the abinet. If taken into the field the hamdle of the brush should be of a bright color, otherwise the bush is often lost.

The Fumigator.-This is not used by Ameriean rollectors, but there are several patterns sold by European dealers. It is intended to smoke out specinens that hide in otherwise inacessible places, $\odot$. g., crarks in the ground, holes in hard wood, ete. The aceompanying figure and the

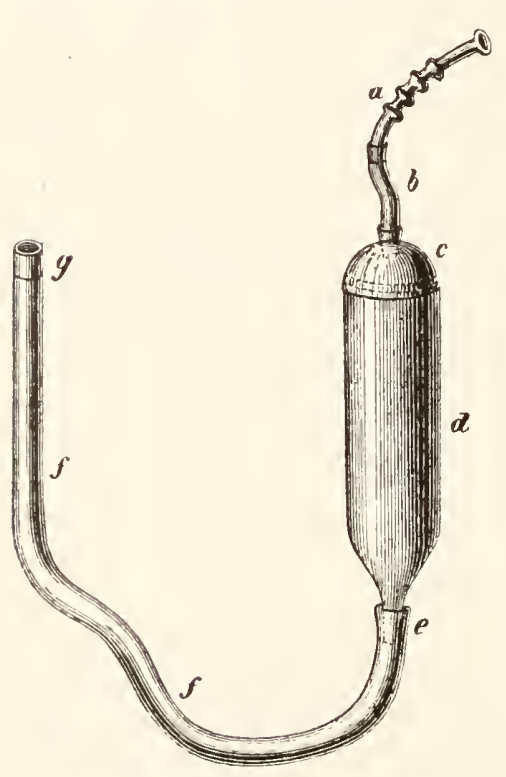

Fra. 59.-The Fumigator. (After Kiesunwetter). following description of a fumigator are taken from Kiesenwetter. A rommon smoking-pipe monthpiere (Fig. 59, " ) with tlexible rubber joint (b) is attached to the cover $(c)$ of a very latge smoking-pipe hear (d). 'To the month ( $($ ) of the latter a rubber hose $(f)$ is attached, which has a convenient discharge at its end $(g)$. The pipe is then filled with tobacco, and the latter ignited by means of a piece of burning tinder placed on top; the cover is then screwed on, and the smoke an be directed to any desired point by blowing air through the monthpiece. The smoke from a common pipe or cigar is often nseful. In sifting in cold weather a puff" of tobacco smoke gently blown orer the débris on the collecting cloth will indnce many specimens to move, which otherwise "play possum" and could not be observed: and further, tobaceo smoke blown into holes and cracks in timber by means of an improvised fimmel made of a piece of paper will be the means of securing many rade specimens.

The Harersuch.-In order that the above-mentioned instruments and the varions bottles, vials, and hoxes which are needed for the preservation of specimens may most conveniently and with the least imperdiment to the collector be carried along on excursions, a haversack is indispensable. This is made either of leather or, still better, of some waterporef "loth, and should contain various compartments of different sizes: one for stowing away the nets, the sirve, and the larger instruments, and several smaller ones for boxes and vials-the whole so arranged that each desired object can readily be taken ont and that nothing will (hop) ont and get lost. The hal rersalek is shug across the shonlders by means of a leather strap, and a full tield ontfit need not be very hary nor serionsly interfere with free bodily morements. 
Many of the smaller objects are most conveniently carried in the pockets of the coat, which acounes, therefore, some importance to the collector. The coat should be of some durable stuff'and provided with many pockets, so arranged that in stooping nothing falls out of them.

The Lens and Wicroscope. - In the examination of the minuter forms of insert life the naked eye is not sufficient, and a hand-lens, or, for more delicate work, the compomml microseope will be found neces sary. I had, in my early experience, some diffenlty in getting a satisfactory haud-lens, and the use ot a poor hand-lens in time injures the eyesight, as I know by a year's rather disagreeable experience. For a hand-lens the achomatio lenses formerly manufactured by A. K. Eaton, of Bronklyn, N. Y., and now made by John Green, 35 Liverpool street, East Boston, Mass., are most excellent in workmanship and are satisfactory in every respect. A very good lens can also be purrhased of any of the leading manufacturers of microscopical apparatus in this country. The kind of compound mieroscope to be purchased will depend upon the matme of the work of the investigator. Tery serviceable instrmuents are made by.J. W. Qneen \& Co., Philadolphia, Pa., and by the Banseh \& Lomb Optical Company, of Rochester, N. Y., and others. The German microseopes are in many respects smperior to those of American make, and if one has sufficient means, I would recomment the purhase of one of the better instruments of Zeiss's mannfacture, which may be obtained either direct from the mannfactures or through Queen \& Co., or from the Boston Erlucational Supply Company. Microseopic material, ineluding slides, cover glasses, instruments for mounting, momuting media, staining fluids, etr., may be obtained of either of the films nancd above.

Having thus indicated somewhat fully the general methods of collecting, and the paraphernalia most desirable in collecting, it will be well to go still further into detail, and in comnection with the different orders give some more specitic information that will be valuable as a guide not only to the general collector, but to the specialist.

\section{COLLECTING IIYMENOPTERA.}

The insects of this order, including Bees, Wasps, Ants, Ichnemmonflies, (rall-flies, Saw-flies, and allied insects lave always been of umusual interest both to entomologists and non-entomologists on areount of their riversifed and pecoliar habits. In abundanee of speries they exceed perhaps even the Coleoptera. In general they are day thiers and always to be fomml in abminduce on bright days about flowers. The best season for collecting is in early spring, on the bloom of the Willow, Alder, and other trees. They may also be foumd at any season of the rear, but the males of many species are only to be taken in fall. In this order, species of many gromps ran be most easily obtained by breeding. This inclndes the gall-making family, Cynipidie, and the parasitic families chaleidida, Proctotrypida, Iehnemmonida and Bra- 
conidas. The Chrysidide and certain other less important fumilies are also parasitic, Jnt are more easily obtained by general collecting. The implements necessary for collecting Hymenoptera are the sweeping-net and the heating-net. Many rare forms of the smaller parasitic families may be obtained by sweeping the grass and foliage of all sorts. The

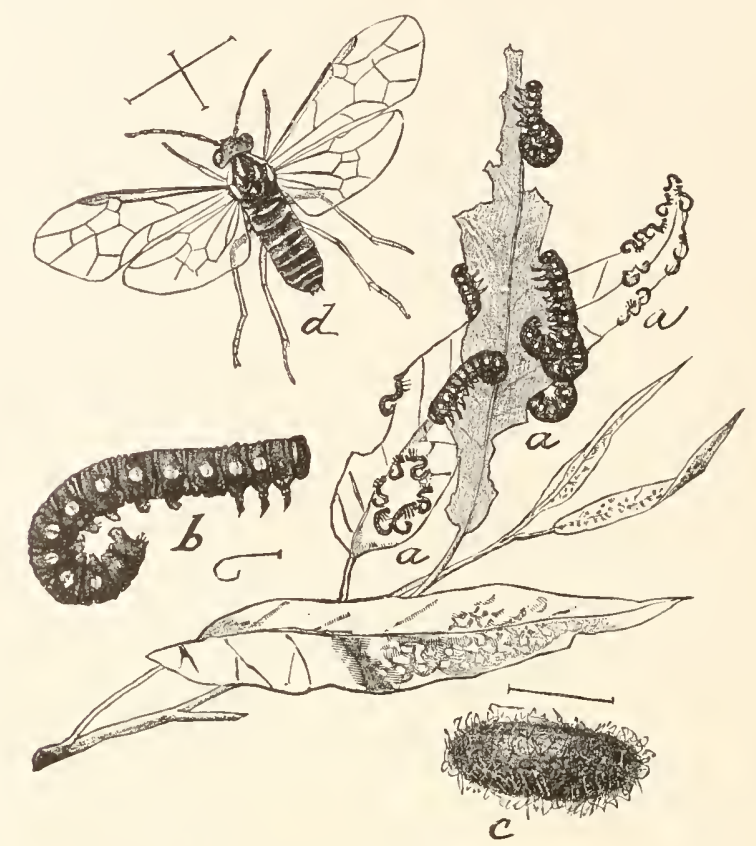

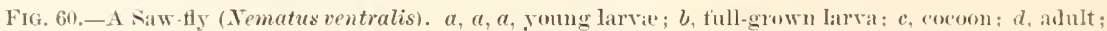
all slightly enlarged.

Proctotrypidle may be collected in quantity by sifting leaves and rub. bish collected in the woods. Mr. William H. Ashmead, who has matle an especial study of this gromp, finds winter sifting profitable. Dried leaves and rubbish are sifted, the finer jortion boing retainesl and transferred to a bag. When a sufficient quantity is collected it is removed to a warm room. Many hibernating species are taken in this way, and, revived by the warnth, are easily noticed when the material is spread on white paper.

On aecount of the interest attaching to a knowledge of the varions hosts of parasitic insects the collector should always aim to obtain the latter by breeding as much as possible. This can easily be done by kereping a lookont for larvat of all sorts which give evidence of being parasitized. The larve of Lepirloptera fombl late in the fall are very apt to be parasitized, and should be collected and kept over the winter. The parasites will emerge throughont the winter season ant in the early spring. Such lavve will be found on the trunks of trees, in the crevieds of the bark, and the cocoons of parasites will also be fomml in similar situations. 
The Tenthedinidae (saw-flies) are not so often tound abont flowers but usmally remain in the virinity of the food-plant of the larval, and may many of them bo collected by sweering. The lanvat of this family are in many cases difficult to breorl, as most of them are singlebronderl, and it hecomes necessary to carry the larve over the winter.

The Gall-flies. Cynipidae, aro the easiest of thr families to collect, because of their abundance and because of the ease with which they may be reared. Their galls oecur in enormons variety on waks of varions species and also mon brambles and certain common weeds. Thest should be collecterl when mature and be kept in glass jars. The Gall fles and infuilinous and parasitie species may thus be easily obtainerl. the former appearing at particular seasons and tle latter emerging from the galls at all seasons of the year, and sometimes continuing to escape for a period exceeding two years.

One of the most interesting families in this order is the Formicidie, which comprises the true ants. In the case of these insects isolaterl specimens slould not ordinarily be collected, and it is especially dexirable to collect the species tirom colonies so that the three forms (males, females, and workers) may be obtained together. This holds also in the case of the social wasps and bees, but the different sexes of the latter may be collected in a season's collecting abont flowers, the females and workers in early spring and the males in the fall.

The Erocerida or woodborers are to be fonnd only abont trees in which the lavie breed. They may frequentlybe taken about tree trunks, or burrowing with their long gimlet-like ovi-

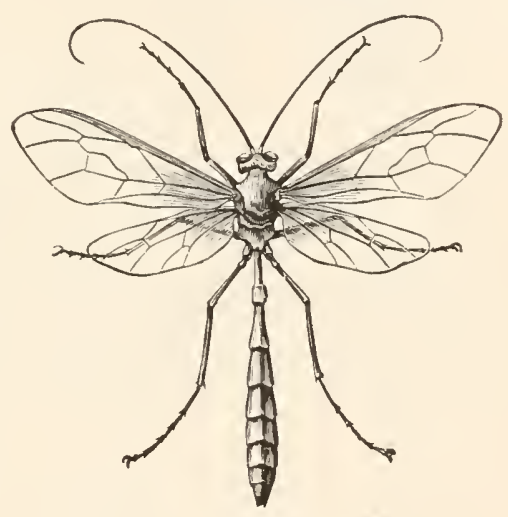

Fig. 61.-An lchneumon (uphirm). positors into the trunks of trees to oviposit. Breeding is also a satisfactory method of obtaining these insects.

Some special methods of collecting Hymenoptera may be brietly outlined. In the case of the social bees, particularly bumble-bers, and also the smaller wasps and yellow-jackets, a very satisfactory method of collecting ronsists in first stupefying the insects in the nost by introducing a small amount of chlowoform, benzine, or bisulphirle of earbon. This shomld preferably be rone in the late prening, after all the insects have come in for the night. The nest may then be opened and examined without any danger of being stmo, and the different forms may thus asily be obtained, together' with any rare parasitic or' inquilinoms insects. In the case of the nests of Bombi this is the best method of obtainme the inquilinous A pathus species.

On aceount of the danger of being stung, and also on areonut of 
the extremely quick flight of these insects, the removing of II ymenoptera from the net is not always an easy task, and in many eases rare sperimens escape. One method of aroiding the danger of being stung is to have the collecting net constructed with an opening at the bottom which, during the sweeping, is tied with a string. When a sufficient quantity of insects is obtained they are, by a few quick motions, driven

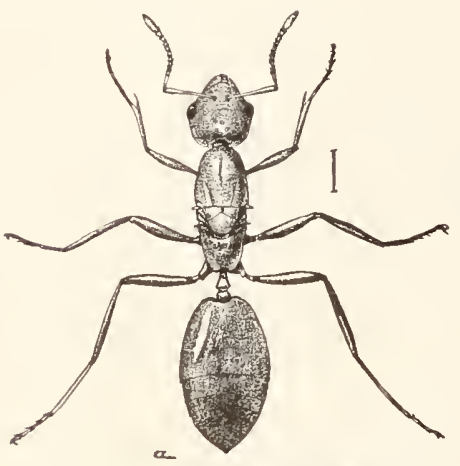

a.

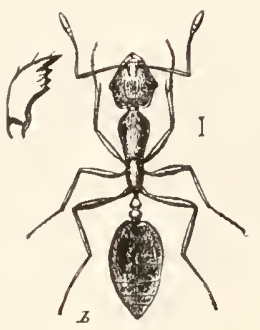

FIG. 62.-The Little Red Ant (Monomorium pharaonis). $a$, female; b, worker enlarged. to the bottom of the net, and the net is then seized just above the insects with the hand, the folds of cloth preventing the insects from getting to the hand, so that there is little danger of being stung. The lowerend is then earefully mitied and inserted into a widemonthed bottle, and the contents of the not shaken out into the bottle. After the eatch is stupefied the vial may be turned out and the undesirable material discanded. A second method consists in the use of an ordinary sweepingnet of light material. A quantity of IIymenoptera are collected firom flowers and driven to the bottom of the net, and secured as in the preseding method. The portion of the net eontaining the insects is then, by means of a pair of forceps, thrust bodily into a large collecting botthe. Atter a few minutes the insects are stupefied and may be readily examinedl.

\section{COLLECTING COLEOPTERA.}

Gevelial Directions.-Owing to their hard outer skeleton, Coleoptera can be collected, handled, and preserved with greater safety and with less trouble than most other order's of inseets. From this fact, and from their very great diversity in form, Coleoptera have, next to tho Lepridoptera, always been favorites. As a consequence, there are now mone species described in this than in any other order, and in the large musemus they are much better represented than other inserts. This rich material has been studied by numerous and competent specialists, and the dassification of Coleoptera is at present more ardvanced and more alcerssible than that of the other order's. This fact gives stimulus to neophytes, and though the literature of our North American fanna is much scattered and we are still in want of comprehensive works (with the exerption of the general "Classitication" by lors. Le Conte and Hor'n), yet, except $n$ a few hitherto neglected families and smaller grouju, the species are fairly well worked 11 ). 
On the other hand, onr knowledge of the earlier states of Coleoptera is yet rery imperfect as compared with the Lepidoptera. Coloopterous larva are, with few exceptions (notably Coccinellida and some chrys. omelida(e), much more difticult to find and rear, and their distinguishing characters are more difficult to study. The few comprehensive works on Coleopterous larrie that have been published are based on rather scant material and nome of them deal with the North American fama.

Coleoptera ocent in all climates and in all localities. Suereies are known from the highest northern latitudes ever reached by man, and in the tropies they ocem in an embarrassing richness of forms. They are foumd in the most arid desert lands, in the depths of onl subterranean caves, and on om highest momtains m) to the him of eternal snow. The open ocean and the open water of omr Great Lakes are the only regions fire from them. As a rule, the number of species gradually increases from the Aretic regions toward the tropies, but it would be difficult to decicle, spealing of North America, whether or not the fatula of the Middle States is poorer in the number of species than that of the Sonthern States; or whether the beetles of the Atlantie slope outummber those of the Pacifie States or those of the ('entral region. On the Pacitic slope the influence of the seasons on insect life

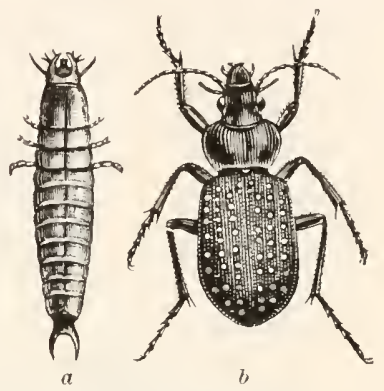

Fig. 63.-A Ground-beetle (c'alosoma calidum). a, larra; $b$, alult. is greater than on the Atlantic slope. While in the latter region a number of species may be found the whole year romd, there is, in the more arid regions of the Wrest, an abundance of insect life during and shortly after the rainy season, with great scarcity during the dry season, except, perhaps, on the high momtains.

Few persons have had a more extended experience in collecting Coleoptera than Mr. E. A. Schwarz, one of my assistants, and the following account has been prepared by him at my request and is given in extenso.

Wixter Collecting.-There are more species of Coleoptera hibernating in the imago state* than in any other order and winter collecting is therefore most profitable in many respects. For instance, great swampy tracts which are inaccessible in the summer season harbor an abundance of rare Coleopteri, which either can not. be fouml in summer time or are found at that season with the greatest difficulty. At the approach of winter, however, all or most of these species will leave the swamp and seek drier ground, where they hibernate under old leaves, under bark of trees, or in rotten stumps near the edge of the swamp. Such places will, therefore, give a rich harvest to the Coleopterist late in the fall, during warm spells in midwinter, and in very early spring. It the temperature is below the freezing point, or if the ground is frozen hard, no winter collecting should be attempted, first, on account of sanitary

* There are a few specios of Coleoptera known in Europe which belong to the true "winter insects," i. e. surh as appear in the imago state only during winter time, bit whether or not we have such species in wu own faum has not yet been ascertained. 
considerations, and also beeanse the Coleoptera then retreat more deeply into the ground and can not be fonnd so casily as when the gromel is free fiom frost. Other good collecting places in winter are the acrmmulated old leaves alome tlus edges of forests or nutler the shrublery along water conrses, thick layers of moss, and the loose lark of deal or dring trees, amb, timally, also nuller the bark of certain living trees, e.g. Pines, Nycanore, Shellhark llickory. Digging in the gronul at the base of large trees or rocks also yields gook returus. The only instrmments nuessiry for winter collectiug are the sieve, the chisel, and the trowel.

SPRING COLLeTIxa. - With thr first rlays of spring, collecting becomes a little more varied. The methods used for winter collecting can still he continned with groorl snccess. Certain spring tlowers, notably Willow blossoms, will furnish many valuable species, which are not seen again during the lest of the seasom.

Myrmecophilons and Trmitophilows species. - The arly spring is also the hest time for collecting the 11 rrmecophilons and Termitophiloms Coleoptera. Temitophilons species have in North America hitherto been found only in comnection with the Whiteants (Termes flaripes), and the inguilinons beetles ad fonnd rnnuing among the White-

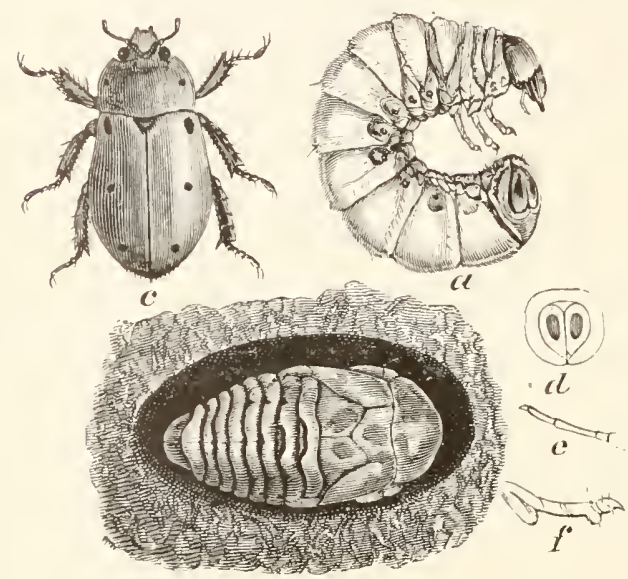

Fra. 64.-A Lamellicorn (Pelidnota punctata). $a$, larva ; b. рира; $c$, beetle; $d, e, f$, enlarged parts. ants in the colonies under stomes, loose bark of trees, and nore numeronsly in the interior of old intesterl trees. Mrrmeeophilons Coleoptera are by far more momerons in species than the Termitophilons speeres and ar" fombl among many species of ants which have their mats eitlee muler stones or loose bark of tries, in stmmps or logs, or whieh construct larger or smaller hills. Cpon uncovering a colony of ants under a stone, the muderside of thr lattre as well as the galleries of the ants in the gromud should be carefinly examinet for inquilines, which from thrir greater or slightrr resemblance to the ants are liable to be overlooked hy au inexperioncol collector. 1i such colony of ants harbors a rare beetle the subterranean part of the colong itselit shonla be dug ont and sifted, but since from the stouy nature of the gromul this is not always practivalue it is to be recommended to carefully replace tle stone muder which the colony has been fomn. Tyon levisiting the spot again the next day or even a firw hours after the first visit addrtional specimens of the infuilines are usually to be olotainel on the stone or in the smperficial gralleries of the ants. Ant colonies in hollow trees aur in rotten logs shonld be sifted and there is no particular diffienlty cumected with this operation. Owing to the puguacions character of the hill-constructing ants it wonld seem to be a rather unpleasant task to examine a strong and rigorons colony for incuilinons beetles, but the collector must not mind being bitten and stung lyy the infuriated ants, and after a little experience lie will fincl that it is not smeh a difficnlt thing after all to attack even the largest ant-hill. The only thorongh way of investigating such ant-hils is to sieve the same. whirh ran be easily donr if the

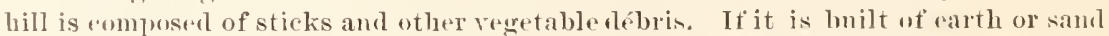
the proesss of sifting is more difficult and tedioms. Another methot of serming specimens of these inquiliuous betles is to plare that stomes ol similar olujects on the smface of the ant-hill and to exanine them nceasionally, when the beetles will be fonmel on the mulersideof the traps.

spring Flights of Coleoptere.-On the first really wam thass of spring commences the "swarning" season of Colroptera, when all winged spereies are tlyingr ahout, 
especially toward evening. On furorable days the number of specimens and species that can thus be found is astonishingly great, and this is one of the fer $\mathrm{W}$ oceasions when the Coleopterist "an arlvantageonsly use a light butterfly net. The flyiug beetles preferably alight and rest on the top of worlen fences (especially newly made ones), on the railings of hridges, ete., where they can he easily seen and secured, or they are attraeted in great numbers hy the white-painted surface of buildings. This ilying season lasts in the latitude of Washington from the end of April to the middl of June, but favorable days are not of frecuent ocurrence, since a peculiar combination of atmospherie comditions appears to be mecessiry to induce the Coleoptera to $\mathrm{Hl}$ about in great numbers.

Beuch collecting.--Aloug the shores of the ocean. aud the Great Lakes untold numbers of Coleoptera and other inseets tall at this season into the water, and, if the tirles, the currents, and the winls be farorable, they are washed ashore by the wares on the sandy beaches, where they often form windrows sereral iuches in lieight and wilth. If the collector is happy enough to be at the right place on the right dity he has then the opportumity to piek $n_{1}$ hundreds of rare species within a rery short time and withont any tronble. Nauy of the specimens thus washed ashore are dead and decayed, but the majority are alive and in exeellent condition. This "beach collecting" affords also an excellent opportmity for the Hrmenopterist and Hemipterist to secure large numbers of rare speries, but favorable days are also here of rare ocenrence.

Atracting by Lights.-On the beaches, day and uight flying inseets ean thus loe captured. Awar from the beach night-flying Coleopteral ean best he collected at the electric lights of on cities; but, as in the Lepicloptera, not all night-tlying speeies are attracted by the light. Gas and other lights also attract Coleoptera, and the various "light traps" that have been devised and described ean adrautageously be nsed for collecting these insects.

Trops. - The method of "sugaring," so important to the Lepidopterist, is by far less favorable for collecting Coleoptera. Still, certuin rare Carabidx, Elateridæ, and Cerambeide are attracted by this bait, and the Coleopterist should not entirely ignore this mole of collerting. There are a tew other methods of trapping certain Coleoptera. By laying ont tlead mammals, bircls, fishes, snakes, etc, on suitable places aul so that they are protected from dogs, rats, ete., the earrionfeeding Coleoptera ran be found in great a hundance, hut a eleaner ant less disigreealle method of obtaining them is to bury in the gromed tin cans or glass jars so that the top is even with the surrounding ground and to hait them with pirees of meat, fried fish, boiled eggs, etc. Mauy Curulimidie, Scolytidie, and numerons other wood-inhabiting species can be snecessfully trapperl in the following way: A number of branches, preferably of only one kind of tree, are ent and tied up into bundles of conrenient size. The bundles are then laid on the ground in a shady place or firmly fastened on trunks of trees. When the cut hranches begin to get dry they will attract many of these Coleoptera, whieh can then be readily collected by shaking the hundles out over the collecting eloth.

Freshets.-Freshets usually take place in springtime in most of our rivers and ereeks, and furnish the means of obtaining a mul-

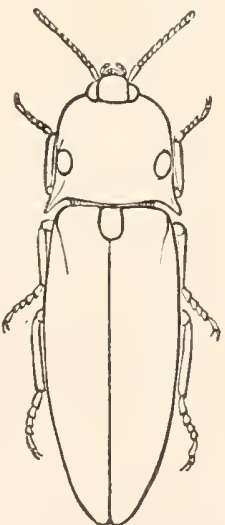

Ha. 65.-An Elateric (I'yrophoius noctilucus). (From Pack arel.) titude of Coleoptera, amoug which there will he many species which ean not, or only accillentally, be found otherwise. These fresbets, sweeping over the low banks or inundating wide stretches of low land, carry with them all insects that have heen canght by the inumbation. Intermingled with, and usually clinging to, the varions floating débris, these inseets are eventually washed askore by the current at rarious points and the Coleopterist should not miss this rare opportunity, lut go ont to the 
river lank at a time when the water is still rising, or at least when it has attained its highest point. Among, or on the washed up débris, a multitude of Coleoptera of varions families can be found, and the specimens can either be gathered up on the spot or a quantity of the débris be put in sacks and taken home, where it can be examined more thoronghly and with greater leisure than ont of doors. A day or so after the floods have receded the washed up specimens will bave dispersed and only a few will remain in the débris for a longer peried. Still more protitable than the spring floods are the summer freshets, becanse a larger and more tiversified lot of Coleoptera is then brought down by the water. A similar opportunity for collecting is offered near the seashore if nunsually high tidles inundate the low marshes along the barons and inlets.

Scamer Collectixg,-During the latter part of spring and throughout the whole snmmer, when the vegetation is fully developed, every possible collectiug metlod can be carried on with success. so that the beginner hardly knows what particular method to use. There are stones to be turned over; old logs, stumps, and hollow trees to

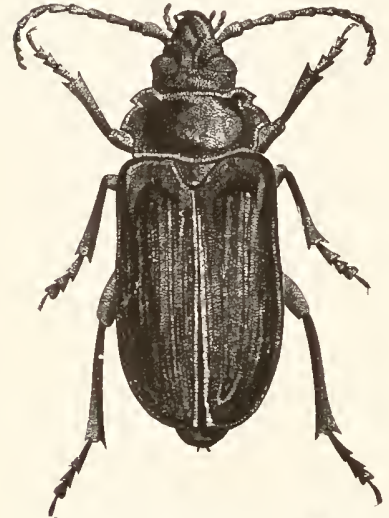

Fla. 66.-A Longicorn (Prionus laticollis).

he investigated; newly fellenl or wounded trees to bo carefully inspected; here a spot favorable for sitting claims attention; promising meadows aud low herbage in the woods invite the nse of the sweeping net; living or dead hrauches of all sorts of trees and shrubs to be worked with the nmbrella; the mud or gravel banks of ponds, lakes, rivers, and creeks aftoml excellent collecting places; the unmerous aymatic beetles are to be collected in the water itself; the dung beetles to be extractel from their nusavory habitations; in the evening tho electric and other lights are to be visited, the lightning beetles cliased on meadows and in the woods, or the wingless but luminous females of some species of this family to be looked for on the cround, and the trees and shrubs are to be heaten ifter lark in search of Mar beetles and other nocturnal leaf-feoling species which can not be obtained at daytime; and, finally, some of the rurest srarabiride and some other species fly only late at night or again ouly before sumise.

In riew of this embarrassing multitude of collecting opportunities in a gool locality, the beginuer is apt to be at a loss what conrse to pursue. Experience alone can teach here, and only an expert collector is able to decide, at al glance at the locality before him, what collecting method is likely to produce the lest results, and his julguent will rarely be at fault.

It is impossible to go into details regarding the varions collecting urethorls, just mentioned, and only a few general directions cam be given rogarling those methods which have not previonsly been alluded to.

Collecting under Stones.-Thrning over stones is a facorite method among begimers and yields chietly Carabirle, the larger Staphylinilat, certain Conculionitar, and a multitude of speries of other families. Stones on very dry gromul are productire, only early in spring or in the fall, while those on moist gromul, in the shade of woods, are good at all seasoms. In the Alpine regions of omr momtainous districts, especially above the timber line, collecting under stones becones the most important method, and is especially favorable along the edges of snow fields. In often fireguented localities the rolleetor shomld carefully replace the stones, esperially those under which he has fonud rare specimens. The negleet of this rule is one of the prineipal canses for rertain rare species having become extinct in the ricinity of our cities.

Collecting in rotten stumps and Logs. - Success in collecting in rotten st umps depends much upon the more or less arlvanced stage of decay as well as mpon the situation 
of the log and npon the particular kind of wool. It the decay is very much advanced neither the loose bark nor the interior of the log will harbor many Coleopltera excepting a multitude of Passalus cocuntus and its larva. If the decay is less advanced, but if such logr is exposed to the scorching rays of the sum, it will be far less productive than a log in a shaly situation. The investigation of the bark of a favorably situated log in the right stage of deeay does not need any special instruction, but the decayed wood itself should be pried off with a chisel or trowel, put in the seive and sifted on the collecting cloth. This is the best way or obtaining the uumerous species of rare Micro-coleoptera of varous families that inhabit such places. A "red rotten" oak or beerh log is more favorable for this mode "f collecting than a "white rotten" of the same or other kinds of trees.

Collecting in dying or dead Trees. - Dying or deal trees almost always harbor a large number of Coleoptera and offer an excellent collecting opportunity until the wool becomes thoroughỉy ary, which usually takes place in large trees two or three years after the death of the tree, and in less time with smaller ones. The bark of such trees is the best collecting place for Cuenjidie, Colydiidie, Scolytida, Histeridie, ete., and it will be found that the shady side of the tree is more profitable than the side exposed to the sum. The numerous Buprestidie, Elateridie, Ptinidia, Ceranbrcida, Melandryide, etc., which breed in the wood can be obtained only with difficulty. Some specimens mily be cut ont from their holes hy a skillful nse of the knife or hatchet; others (especially the Buprestidir) may be found resting on or crawliug over the trunk in the bright sunshine, whila the more nocturnal species may be fouml on the tree toward evening or atter dark, when, of course, a lantern must be used. A large proportion of the species living in the trunks of aleal trees also breed in the dead branches of otherwise healthy trees from which they cau be beaten into the umbrella, or where the use of the kuife is more practicable than in the large trunks. The trunks of freshly felled trees attract numbers of Cerambycille and Buprestide and have to be carefully looked over, while the drying foliage of such trees affords an excellent opportunity for the use of the umbrella.

Beating liring Tiees, Shrubs, and Fincs. - The suceess of beating into the $11 \mathrm{m-}$ brella branches of living trees and shrubs depands on the particular kiud of tree or shrub, on the condition and situation of these, and largely also npon the season. Pine trees are very productive from early in the spring to early in the summer, but much less so in midsummer and later on. Young Oak trees or Oak shubs are much more preferred by the leat-eating Coleoptera peculiar to this tree than the older trees. The Beech, which, nest to the Oak, is the best tree for woor-boring species, harbors but few leaf-eating species. The leaves of the Chestunt ale also geuerally not attacked by Coleoptera; still a surprising number of species cau be beaten from this tree when it is in blossom. There is not a singlespecies of coleoptera known to live in the wood or to feed on the leaves of the Holly (Ilex glabia); still it will pay the Coleopterist to beat this tree when it is in bloom. Trees, shrubs, and vines in the interior of muloken forest districts are, as a rule, unproductive, while the edges of the woods, narrow strips of hedges, and esperially solitary trees are excellent collecting places. In the liocky Mountains, esperially in the more southern sections, long stretches of nountain slopes are orcasionally perfectly bare of vegetation with the exeeption of a few solitary, siekly-looking, and dwarfed tres, hut every one of these is a veritable gold mine to the Coleopterist with his unbrella.

Sweeping. - The use of the beating net continues protitable from spring till fall, a different set of species appearing with each season. Low and swampy mearlows, meadows on the slopes of momtains or surromiled by woods, low underbinsh, and herbage in smaller patches of woods are very good beating grounds. Dry and sandy meadows are less prodnctive, hut harbor usually a different set of species on account of the difference in the flora. l'astures and mealows mueh frequented by eattle and horses are much less productive, and where a large number of sheep are kejt there is usually no chance for using the beating net, sinve neither grass nor specimens are 
left. The lawns in onr parks and gardens are usuall: poor collecting groumd on aceonut of the liniterl variety of plants in such places; but the few species lonud there oecur in enormons number of specimeus. The endless stretches of onr western prairies swarm at the right season (in June) with.numerons Coleoptera (mostly Ma-

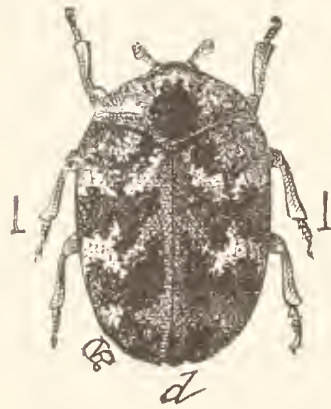

d

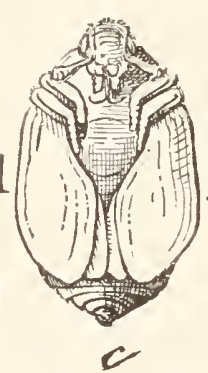

$c$
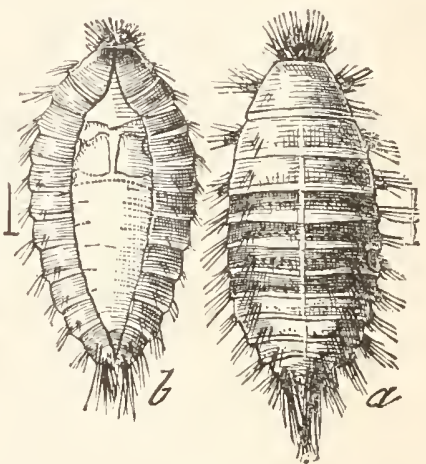

FIg. fii. I Dermestid (Anthrenus serophularice). a, larva, dorsal riew; b, larva, veutral view; $c$, pupa ; $d$, adult_all enlarged.

lachiidie, Chrysomelisle, Mordellidar, Curenlionidie, etc.), provided prairie fires have not swept too frecuently orer the place. Fires and cattle produce a remarkable change in the flora and famua of the prairies; manc indigenons species disappear or become scarce aud are replaced by a much smaller number of importer species.

Sweepiug may commence in the forenoon as soon as the dew has clisappeared; it is less profitable in the heat of the milday, but produces the best results lite in the afteruon and more especially in the short interval from just before sunset until dark. At this tinue many rare l'selaphida and scydnieuidie, species of the genera Color and Anisotoma, and other small silphide ean be beaten from the tips of grasses. all being slecies which can not, or ouly accidentally, be found duriug day time, when they hille between the roots of plants.

follecting on mud and gracel Banks. - The mud or gravel banks of ricers, creeks, and staguant bodies of water are inhabited, especially early iu summer, with an astonishing multitude of Coleoptera. Conntless specimens of smaller Carabida (Dyschirins, Clirinu, Bembidium, Tachys, ete.) and staphylinide (Tachymse, Philonthus, Actobius, Stenus, Luthrobium, Trogopleleres and many other genera) will he seen actively ruuning over the mud or sand; many other specimens are hiding under the pebbles in company with other species (Cryptohypmes, Georyssus, etc.) or in little subterranean galleries (Dyschirius, Bladius, Hetrocerus). All these beetles must be collecterl by pirking them up with the fingers, an operation which, owing to the activity of the specimens, recunires some little prictice. The heginner will at first erush or otherwise injure many of the relicate specimens, the capture of which is moreorer loy no means facilitated by the rapidity with which most of them are alle to take wing. The collector must necessarily kneel lown and he must not mind getting covered with mud. A gool devien for driving these species ont of their galleries or from their hidling places under stones or in cracks of the wronud is to pour water over the hanks, and this can in most eases be done with the hand. Larger stones and pieres of woorl or hark lyiug on the bank are ficorite hiding places of certain larger

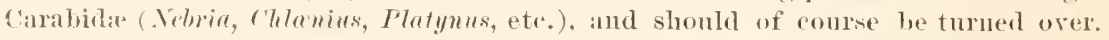
Finally, the moss growing on rocks and logs close to the water's edge, and in which. hesidre other beetles, some rare Staphylinide and the Byrrhid genus Limnichus can be foumd, shonld he seraped oft" and investigated on the collecting cloth w on the surfilce of a tlat lock, if such he conroniently at hioml. 
Collecting aquatic Beelles.-The fishing for water beetles in deeper water by means of the water net has already been alluded to (1\%. [32]), but many species live in sliallow brooks with stony or gravelly bottom, where the water net can not be uset. The Dytiscirlie and Hydrophilida liviugiu such places usually hide under stones, and can in most cases be easily pieked up with the hand, or a little tiu rlipper or a spoon will be found convenient for catching them. The species of the family Parnida are found on the mulersirle of rough stones or logs which are oither partially or entirely submerged. Thry are more numerons, however, in the moss or among the roots of other plants that grow in the water. Such plants have to be ynlled ont and examinerl over the collecting cloth.

Collecting at the Seashore and on sandy Places._- I large number of species helonging to varions families live exelusively in the vicinity of the ocean, some on the open beach, others along the inlets, bayous, or salt marshes, and still others on the dry sand dunes. The Cieindelie are actirely rmming or flying abont close to the water's edge and have to be captured with the butterty net. The remaining maritime species live hidrlen under the seaweed and other débris cast up hy the wares, or in the sand (sometimes quite deep below the surface) beneath the débris or between the roots of the plants growing on the dumes. The majority of the maritrme speeies do not appear before Jume (in the Middle States), but the collecting remaius goorl until september.

In dry samily places away from the seashore, the collecting at the roots of plants is especially to be recommended,

and the plants, and more especially the humches of coarse grasses usually growing

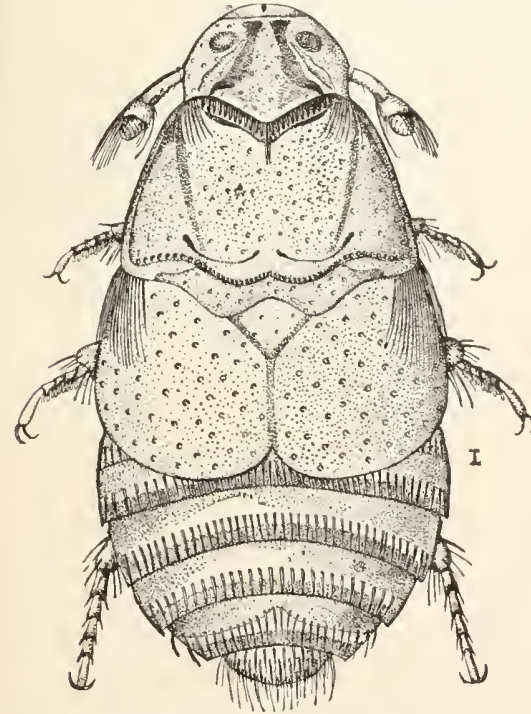

Fig. 69.-The Beaver Parasite (Platypsyllus cas. toris), adult-greatly enlarged.

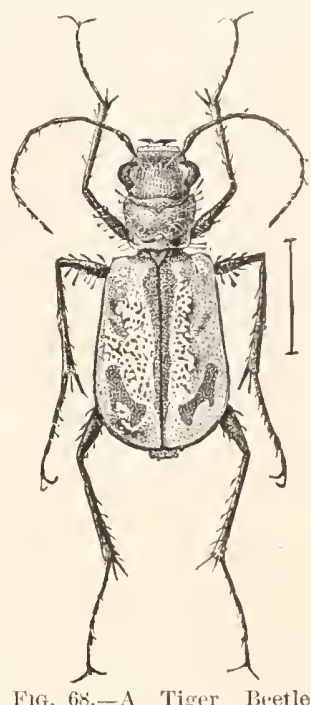

(ricindela limbata), dram by Miss sullivan-enlarged. in such places, should be pulled up and shaken out over the collecting cloth. This mode of collecting acqures a great importance in the arid regions of the West and Fouthwest, where, in the warm seasou, nearly all Coleoptera are hiding during ras time in the gromud at the roots of plants.

Collecting Dung-betles.-The collecting of the numeroms species (Hydrophilide, staplylinida, Histeride, sremberida, ote.) which live in the droppings of varions animals is hy no means an agreeable task. The collector shoul p provide himself with a pointed stiek and collecting tweezers, and must manage to pick up the specimens as best he can. The larger specimeus are best collected in alcohol, while the moro delicate specios can be collecterl in a clesurer condition by removing the droppings and sifting the ground heneath the same. Some speeies hido deep in the ground beneath the droppings and have to be dug ont. Sumurr freslets, when pasture lauds are inmudated, offer an exerllent opportunity for collecting the dungmhaliting species in a clean condition.

2564 
Night Collecting. - The heating of trees and shruls after dark is a good method of

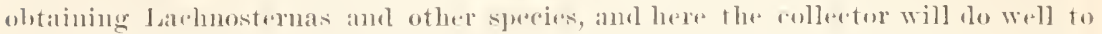
secure the assistance of a contuanion, who takes "hatrge of the lantern amd the collecting botgles, while the collect or himself works the mombellat.

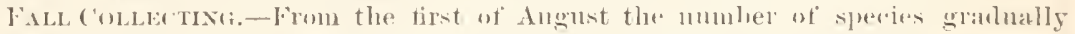
eliminishes, but late in the snmmer ore early in fall cluite a umber of other spereses

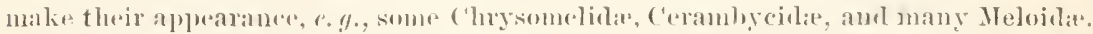
Nany of these frequent the blossoms of (iolden-rods, umbelliferous amb other latellowering plants. The fall is also the hest season for collecting (oluoptra living in

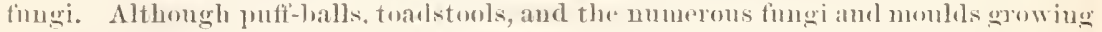
on old trees, "tr., furnish many speries of Coleoptria also earlier in the season, ret most fungi, and mose esprejally the toadstools, flomish best in the fall, and conse-

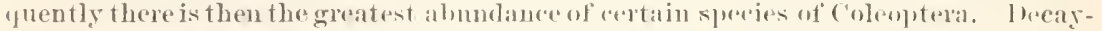
ing toalstools are especially rich, and should lue sifted, and the wollector shonld also not ouit to examine the soil leeneath them.

During the "Inelian sumuer" there is usually a repetition of the ".spring llight" of coleopteria, thomgh on a smallor seale, and collecting on tha tops of leme ponts

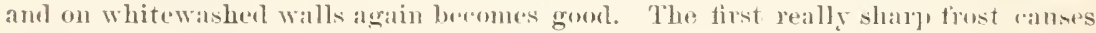
these late opreies to disappear, amd winter whlleding wommenes again.

\section{COLLETTING LEIIIOPTERA.}

In this oreler the importance of collecting the early states and of realling the ablutt inserts rather tham of catching the latter shemlel. if the collector has the arlvancement of knowledge and the guratest pleasme in

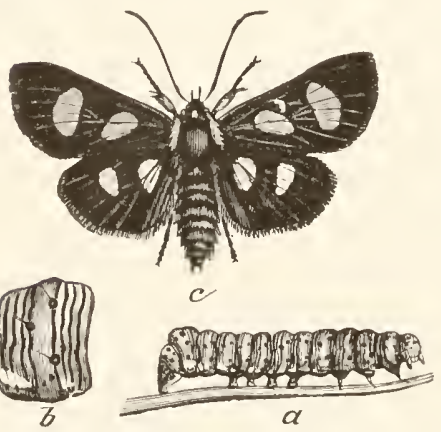

FIG. 70, The Eirht-s potted Forester (Alypia octomaculata). $a$, larva; $b$, en. larged segment of same; $c$, moth. mind, he insisted mpon. Collerted spmeimens, in the majority uf ases. will be more or less rolubed or dambaged amd mofit for permanent loseping. and will always be fall inforior to toslaly leared specimens. All Lepidopterists, therefore, rely to a great extent mon breeding rather than mpon field rollecting. There ane, lowerere, many speredes of winch the early states alle still molimom, and these ean only be talien by tiolel aollecting, and loy attracting to valuous lights or trajs. This suleject, thedetine. natmally falls into twa rattegoldes-(1)

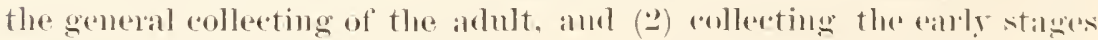
and reaning the pextect insects.

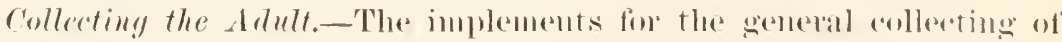
lutterllies comprise the collecting met, and in some rases the heating

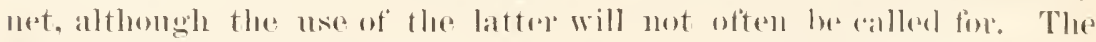

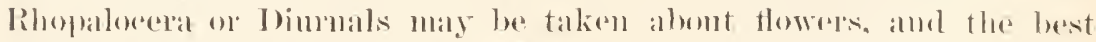

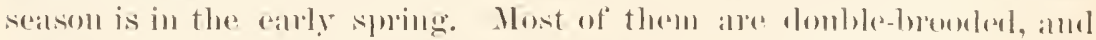

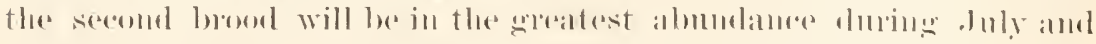

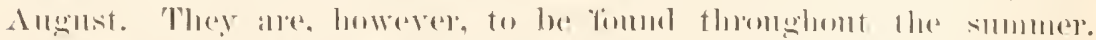

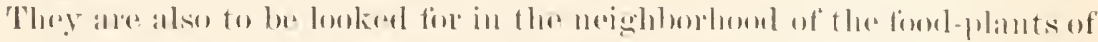

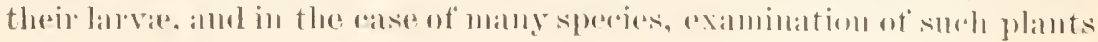


affords the most sat isfactory meansof collecting. The foud of butterfies is almost exchusively the neetar of flowers, but strangely enomgh they are also attracted to decaying animal matter, and many species, incholing lan forms, may be takon abont deaying animal natter or resting on spots where dean animals have lain, or beneath which they have been buried. Moist spotsof earth are also frequented by them, especially in dry seasoms. Many of the langer butterflies, whose larvae feed on the taller shrubs amol the foliage of trees, will be found fluttering about the open spalees in forests, but by far the langer numbere, as the Browns, the Bhes, the Vellows, and the Whites, which develop on the lower herbaceous and sucenlent plants, will be found flying over fields, puanies. and gardens. C'repuscolar amd nocturnal Lejoidoptera, comprising most of the Hoterocera, the Sphingide, Bombereds, Noetuids, ete., have

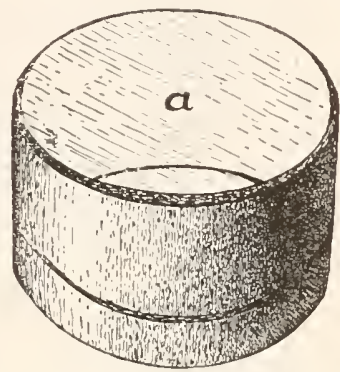

Fig, 71.-Collecting I'ill-box. a, glass bottom (original). different habits. The Sphlingidae or Hawk Moths fly in early evening, and may lo collected in quantity abont such plants as the Honeysurkle, Thistle, Verbena, Petunia, eto. The lombycids and many Noctnids also fly in the early evening, hut mostly at night. The formel, howerere, do not freprent flowers, except such as are the fond-plants of their lanva, as their mouthparts are rulimentaly, and they take no nomishment.

Collecting by the ain of strong light is a favorite means for moths

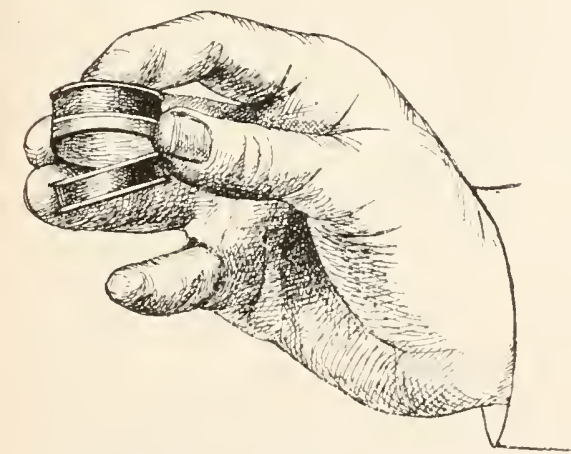

Fig. 72.-Method of holding and manipulating eol lecting pill-box in eaptuing (original).

as well as other insects, and lowarlays the electric lights in all lamere rities fimmish the best collectimg places, amd humberls of spereses may he taken in almost any desired quantity. In woods or in other situations they may be attrateterl to a lantern or to a light placed in an open wimslow. Various trajos have been devised, which comporise a lamp witls appalatus for letaining and stuperfying the insects attracted to the light. The eommonom form is matre by poviling a lantern with a strong reflector. Enoler the light a funnel several inches larger than the lantern reaches fown into a box on bottle containing the fumes of chloroform, ether, or benzine.

11\%. Jerome Mr. Teill describes at length and figues in the Ameriren

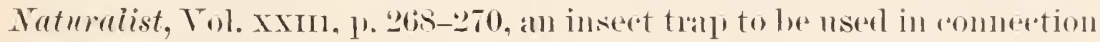

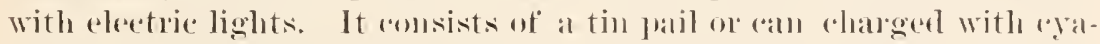
nide after the mamner of a collecting bottle, which is attached beneatle the globe af the electric light. 
The inserts attracted by the light strike against a vertical tiu screen fixed above the ean and fall into a tin fiumel the small end of which enters and roses the month of the cant, and they ale thes coudured into the last. A smpport or post in the eentel of the an beats a lonllow tin rone, the alex of which is piereed with a mumber of small holes to ablut light, and enters and partly closes the lower end of the fummel. The entine interior of the an is painted black and the chiref light eomes

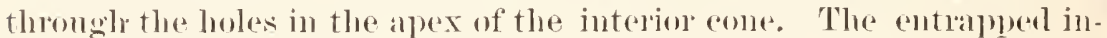
secots endeavor to escalue by crawling up the central post towards the light coming thromgh the small holes in the end of the (one rather than by the entrance slit about the latter and fall back repeatedly until over("ome by the eymide.

Many of the Lepidoptera will be mined by the beetles and other insects or by theil own ineffectual attempts to escape, but coleopteral, Hymenoptera, Nemoptelas, and Hemiptera ara sermed in satisfactory condition.

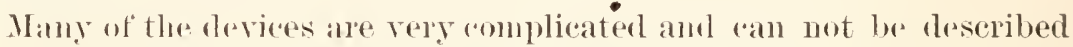
in this rommertion. The nortumal speries, also, fly into om homses, and this is especially the case in the comntry, and an open window, with a strome light reflected onto a table covered with either a white paper or a white cloth will keep one busy, on favolable nights, in properly taking care of the specimens thens attracterl.

Another favorite methor of eollecting moths early in the erening, or as 'ate as or later than minhight, is loy sugaring. This consists in smearing a mixtme of sngar and vinegar, or some similar componud, on the bark of trees or on the boards of fences; and visiting the spot form time to time to collect the moths attracted to the bait. It has been fomud that the use of beer or some other aleoholic liguor, as anm or buandy, with the sugaror molasses water, greatly adds to its efficiency in attracting the moths. This method of collecting moths will be fonnd especially effieient on man'm, moist, elondy nights. The collector shoml be provided with a dark lantern and a good net, and a number of widemonthed ryande collecting hottles. The smearing shonde be done just before dark, and I have always fomed that better success attends this method of collecting when two are engaged in it-one to hold a bull's eye lautern while the other bottles the specinens. Experience will soon trath the surest way of approathing and abturing the specimens.

For collecting Ilierolepirloptera, in addition to the ordinary net, some special apluatustin will be fomd very essential. Lumd Walsingham makes use of a special glass-hottomerl pill-hox, with which to eapture specimens, and the satisfactory natme of the work done with this box, and the dexterity acquired by practioe with it, I can volnch tor by persomal experience. These glass pill-hoses are nseful, also, in arluitting of the examination of sperimens, so that worthless of common speries ean be discanded amd only desiued forms kept. The method of holiting these boxes is illustraterl m the aroompanying illustrations.

(Figs. 
72, 73.) A drop of chloroform on the bottom of the box at mice stupefies the capture so that it can be taken ont and otherwiise dsposed of.

The neressity of raring to obtain perfert specimens is even mores important in the case of the Microlepidoptera than with the larger forms, and many species are very easily reared and can thus be obtained in quantity. The Micros are abmolant from early spring to late fall about shrubbery, in open fields, ant along the edges of woods. They are, for the most part, day fliers, heing on the wing chiefly in the latter part of the day and early evening. As soon as collerted they should be

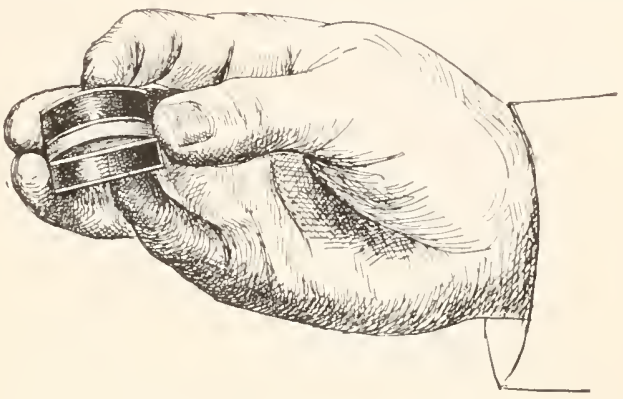

Frg. 73.-Same, showing nethod of closing pill-box after the specimen is secured (original).

transferred to pill-boxes and the greatest care shonld be exereised to avoid mutilating them, as the slightest touch will denude them of a portion of their seales or break their limbs or antemne. Lord Walsingham thns gives his experienee in collecting Micros:

I go out with a coat provided with large pockets inside and ont, rontaining an assortment of pill-boxes, generally of three sizes, glass-bottomed pill-boxes preferred, a bag slung over my shonlder, and a net. L'nless searching for particular day-flying species. I prefer the last three lomrs before dark. Is the smu gores down many species move which do not stir at other times. I wath the tops of the grass, the stems of the flowers, the twigs of the trees: I tistmple leares and low-growing plants with a short switch and secure each little moth that moves, taking each out of the net in a separate pill-box, selected aceording to the size of the insect, as he rums nu the net to escape. Transferring the full boxes to the hag I eontinne the process until moths cease flying or night sets in. Many speeies can he taken with a lamp after lark.

Collecting the eurly stutes. - The eareful entomologist who prides himself on the appeatance of his specimens, will, as stated alove, rely largely on collecting the earl; states and on reariug the insects, for his material. The Macrolepidoptera have either a single or two hroods, or more, in a season, and the collection of the early states will be greatly facilitated if a knowledge of the inseet's life-habits is first ohtainerl. The eggs are often found on the food plants of the species, ansl where they are deposited in masses they affiond a very asy method of getting" the larve in number's. In many cases, however, the eggas are deposited singly and their discovery then becomes a diffienlt matter.

Iore satisfactory in some respects is the method of obtaining the egges from captured gravid females, and the general collector should always be on the lookont fin females of lave species from which he may he able to obtain eggs. A single hattered female may, in this way, be the somre of large numbers of excellent reared specimens. Many rare Lepidopterous larve may be obtained by the use of the beating uet and by 
beating foliage over an 1 mblella. A rery satisfactory methor consists in collectings pupe, which may frepmently be tomd in mubers about the bases of the trees on which the larve feet. Mamy larve of the large family of Owlet Moths (Nortnille) are foumb eithere on the surface of the glomel of muler valums substances, while others burrow into the stems of the different lerbaceons plants, some being sulnaquatic and feeding on the mulersile of leares or in the stems of aquatic plants. In the rase of Mirolepidoptera, their habit as larvate of mining leaves or tying or webbing them together, ationds an easy means of detecting their presence in most cases. Thr minces are easily noticed by the rliscolorel spots on the leaves or the wayy, pale, or blown lines marking their burows. The presence of others is indicaterl by the leaves heing drawn together and united with webs, or withered and brown trom being skeletonized by the latrve. Many species are case-bearers, and live upon the leaves and branches of trees and plants, flagging their cases along with them. Others burrow in grasses or in the stems of plants or the trunks of trees, or in fingi. In the case of the leaf-miners and leaftiers, little rifficulty is experienced in rearing the imagoes.

The eare of the larve, the ontfit required, and the methods of breeding will be describer in later sections.

\section{COLLECTING REAIPTERA.}

For the most part the directions for collecting Coleoptera will apply to this orler of insects equally woll, especially so far as concerus the

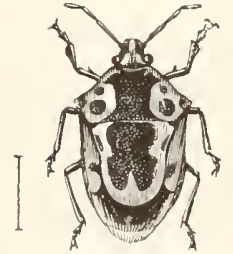

Frg. 74.-A I'entatomid (stiretrus anchoraga). first section of the order (Heteroptera), and the bigher families of the secourl section (Homoptera). A few dinections ma be given tor the lower forms, incluting the Aphidirlae, Concille, Alemodidie, ant P'syllidre, and the suborder Parasita, ineluding the degraded forms which infest man and the lower animals. The Plantlice or Aphides should always be collerted in connec. tion with their. foom-plants, and it is very essential also to rolleet the siture species at rifferent seasons of the year to obtain the lifferent finms ol generations, whiveli freepuently prosent very marked differencen. It is also rery neeessary to se. colle the winged forms, which alle

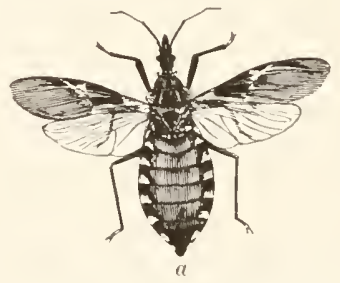

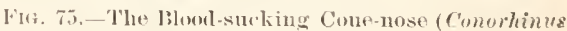
sanguisuga). $a$, miture lug; $b$, pupa. usmally produced towad antumn, and without which the speedes are not easily identitiel. The bark lin. of Seale-inserets should also be aollecterl in anmection with the leaves of twigs which they infest. The malesof these insects ane minutrand, as a lolle, two-winged, resembling small ganats, and may he bred fiom the male seales. The females alle for 
the most part stationary being fixed to the plant by the protecting, waxy, excretion or scale. The Flea-lice (Psyllida') frequently prorluce galls, and these shonld always be collecterl with the insert architerts. Some species do not produce galls, and may be collecterl by sweeping. The Hackberry is infested by large numbers of speeies of Psyllids, and these produce a great variety of interesting galls. The Alemodida (Fringe-scales) are delicate insects, and easily injured in the taking; they are therefore best reared from their stationary and fringed larrie and pulue, which or-
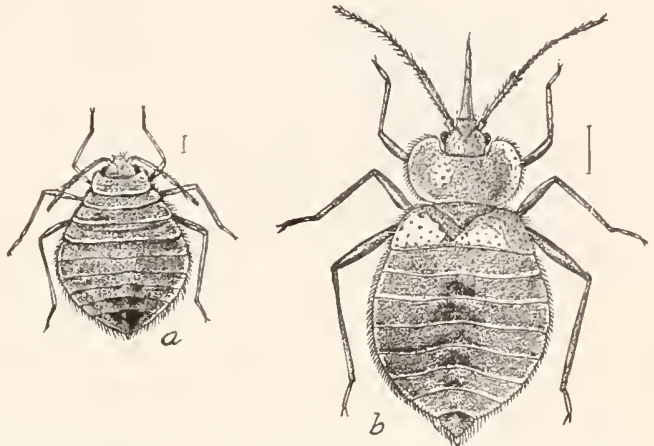

Fig. 76.-The lied-loug (Acanthia lectularia). a, young; $b$, atrult-enlarget. cur on the leaves of many plants. Leaves bearing the latter shonld also be eollected and pinned or preserved in aleohol. The P'arasita, the
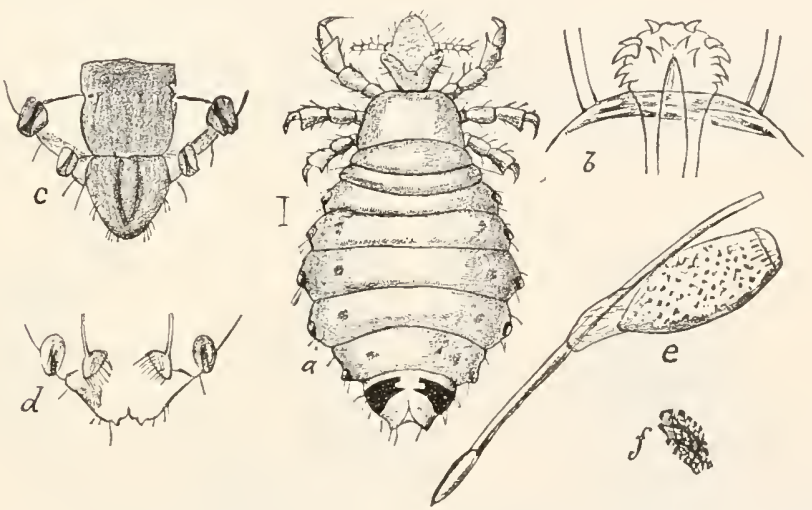

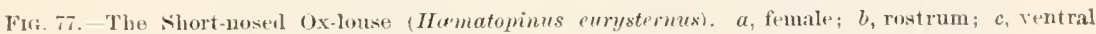
surface, last segments of male; $d$, fimal'; $e$, esgr; $f$, surfice of ego greatly enlarced.

lowest representatives of the order, may be obtained fiom the domestice and wild animals which they infest.

\section{COL.LFC"TINI: DIPTTER.}

Most Diptera fiequent flowers and may be collected with a sweeping net withont much difliculty. The best season is from April to Jume, and the bloom of the Willow, Alder, Plum, Cherry, Dogwood, Black berry, ete., will ordinarily yield a bountiful smpply of specimens and species. Parasitic and saprophytic forms may also rearlily be obtainerl by brecoling, the former as in the case of the parasitic Hymemptera, and the latter from deraying regetable matter and mngi. The Iniptera 
require the most delieate treatment, and the greatest canc mont be exereised both in collecting and handling. A light sweep not is the

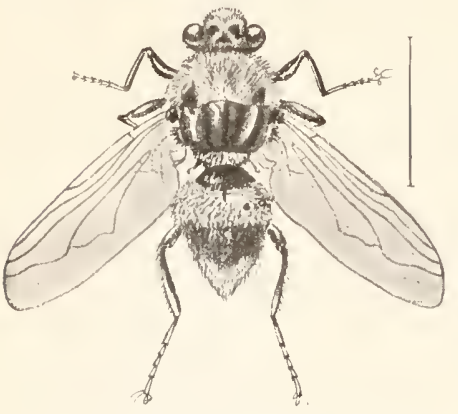

Fic. 78.- Ox Bot-tly (Hypoderma bovis) ('mlarged. (After Brauer.)

best implement for collecting and the contents of the net shomld fieguently be emptierl into bottles provirled with blotting paper to alsworb the exeess of moisture. Tery small biptera should not be killed when theycan not be immediately pinned, and hairy flies should never be taken from the net with the hand, but slomldbelnandled with tine forceps. A pair of special collecting shears has heen used by Lord Walsingham very sucoessfully. It is represented in the accompanying figme, and eonsists of a pair of soreen-covereal disks, betreen which the fly is canght. The insect is at once pinned throngh the sereen and maly be removed and transfrred to a box containing a sponge soaked in chloroform. The

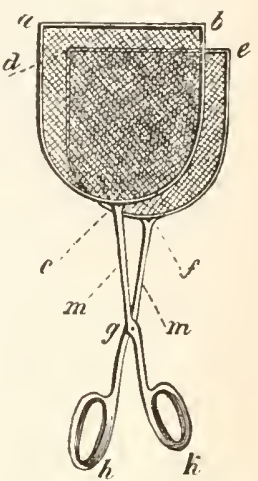

Fig. 79.-The collecting Shears. (After Kiesenwetter.) use of this implement is especially advisable in the case of the Bere-tles (Bombitide) and other hairy forms which are liable to be rubbed when
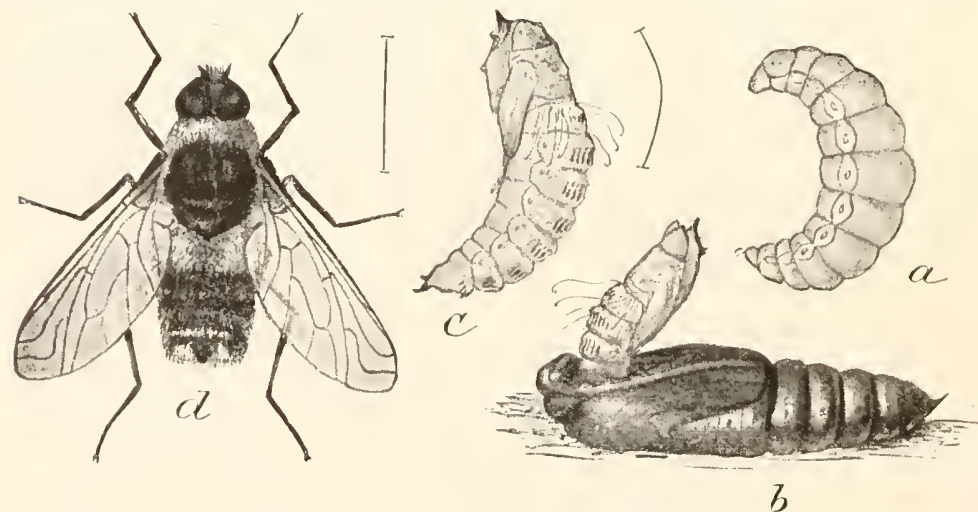

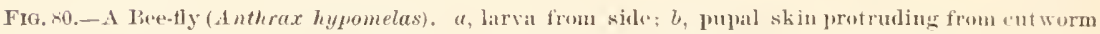
chrysalis; $e$ pupat ; d, imagu-all enlarged).

collected in thes ordinary net. The Gall-making Iiptera (Cecidomyidre) are of little value mulesis aleomupanied with their galls, and the aim shomld always be to eollect the galls and rear the inserets lather than

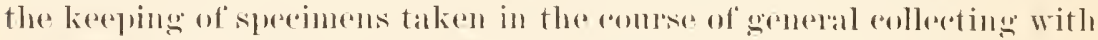

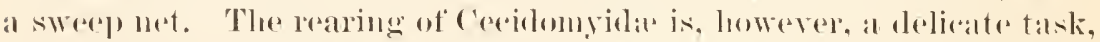

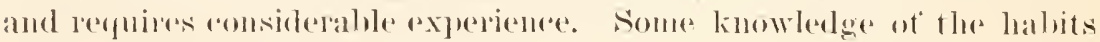


of the species is very essential to success. From immatme salls no rearings need le experted. A goul plan is to examine the galls from time to time and rollect them when it is fomel that the larvar are breginning to abandon them. In the case of species like the common fome Gallgnat of the Willow, the larve of which do not leave the gall to mulergo trausformation in the eartl, it is advisable not to gather the galls mutil the transformation to the pupa state takes place, which, in this species, ocents in early

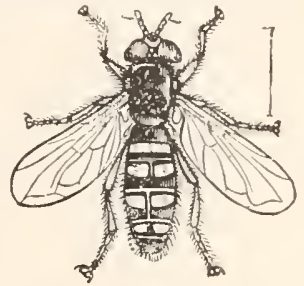

Fig. 81.-A syrphus-tly. spring. The varions leaf-mining and seed inhabiting spereses ran be treated as in the casce of the Mierolepidoptrara.

\section{COLLECTING ORTIIOPTERA.}

The inserts of this order may all be collected by the use of the sweeping net. Some of the families are attrarted to light, as certain of the roaches and green locusts, or Katydids (Lorustider). On common roaches (Bluttirle) are cosmopolitan inserts, and infest dwellings. Certain species are also found ahout pouds, under rotten logs, the bark of trees, and particularly in dearying vegetable matter. In the tropics the species are very abundant, but aside from the domestic forms, they occur rarely in northern latitudes. The rollection of the egg.cases (oïheral) is important as they fomish many interesting characters. The Mantide, of which the Preying Mantis (Phasmomantis conoliun) is

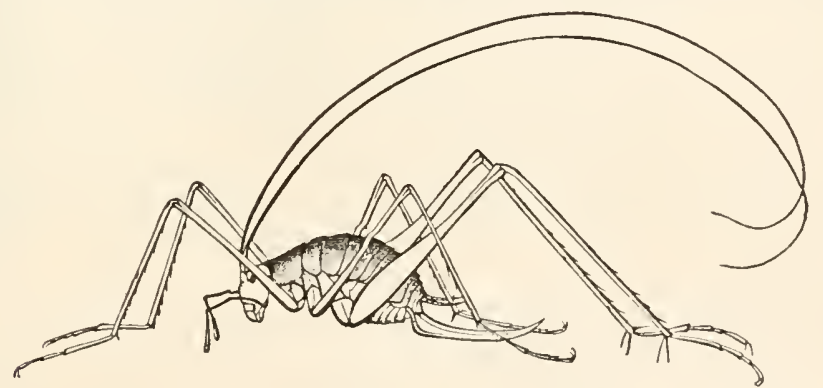

Fig. 82.-A blinl Cricket (Hadenaleus) Irom 1 ammoth Cave. (From Packarl.)

a type, are slugyish, camivorous insects frequently found about homses and may best be collected by general sweeping of vegetation. The Phasmida or Walking-sticks are hed livorous and may becollecterl in the midst of vegetation ly sweeping or by the hand. The ericliets (Gryl. lirle) frequent, for the most part, moist situations. Certain forms, ìke the Mole-ericket and the Jumping Water-erickets (Trylactylus swl\%). burrow in moist soil and ocem in numbers near thr edges of ponds and water courses. Thr katydicls and locusts are abumlant on low shrubs or trees and in pastme and meadow land, but ane most mumeloms in the somewhat dry, arid regioms of the West. Most of these inserts 
mature in late summer and fall and should be rollected at this season.

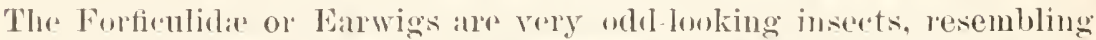
somewhat the liove-beetles (stuphilimilre), and an puovided with a prominent anal foreeps. 'They ane very rare in the lonited States, are noetmonl in labit; and, Hying abont at dusk, may be attracted to light w may be secured by swerping after nightfall. They feed on Howers all timit.

\section{('OLLECTING NEUROP'TERA.}

As indieated in the preliminary onthue of dassification, this large order has been dirided into many orders by later entomologists. It las also been divided, as indicated, into two gland divisions, the Psendonenroptera, comprising those insects with incomplete transformations, and the Nemoptera proper, comprising those insects whose metamor-

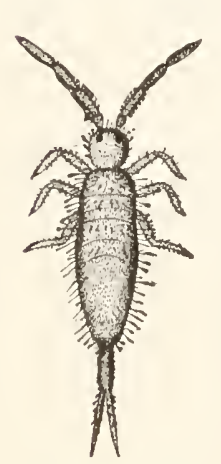

FIG. 83. A sipring. lail (Degeeric lanuginosa). phoses are complete. It will beconvenient to discuss these insects muler these two heads.

Psemdonewoptero.-Bpring-tails, Bird-lice, Ntone-tles, White-ants, Dragon-flies, May-flies.

'The Spring-tails, Fish-moths, rte., representing the primitive stock fom which the higher forms have developed, liave a varied liabit and hence are to be found in divers situations. The Spring-tails (Collembole, etr.), oceur in damp and moist places, usually in immense mumbers. The Fish-moths and Book-mites are common household pests, but also oecur outdoors under logs, boards, bricks, and rubbish of all sorts. In houses they feed on the starch paste lorneath wall-paper and also on the starch in bookbind ings and other domestic articles. They may be collected at all seasons and a sieve is the only implement necessary.

The Bird-lice or Mallophaga may be collected at all seasons on birds and mammals. A number of species intest clomestic animals, horses, eattle, etr., lut the

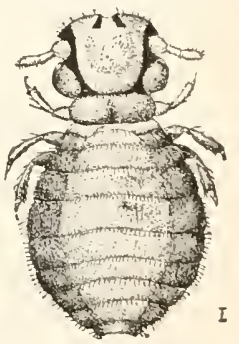

Fitr. 84.-1 Mlalloply. : wau (Trichodectes latus). (Aftir 1)enny.) majority of them an be fomm only ly the examination of domestie fowls and wild birds. The Stone-tlixs (l'rolidre) are fonnd in the neighborlooul of water conses and ponds, arre very slugeish in flielit, and

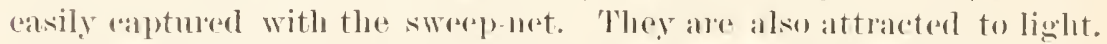

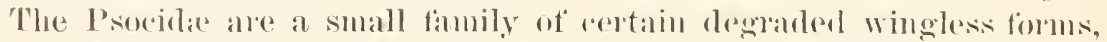

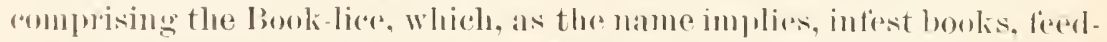
ing on the stande of the binding. Others have ample wings and closely

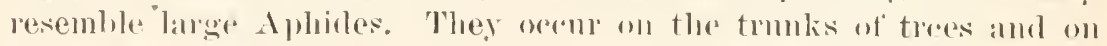

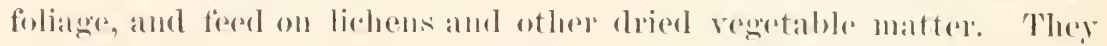

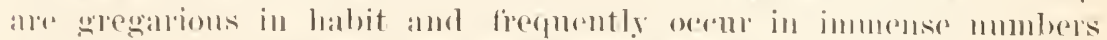

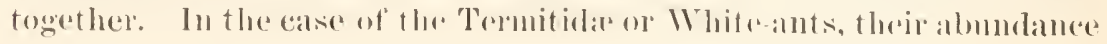


renders their collertion an easy matter. Effort, however, shonld be made to diseorer the different forms, the females and soldiers as woll as the workers. The former may be formel in rot. ten tree trunks, but are very rarely mot with. In the tropies many speries oecur and comstruet curious nests, either attaching them to thes houghs of trees or buildiug them in the form of prramids on the gromnd. The Iragon-tlies ( $\mathrm{Li}$ bellulide, are collected in the same way as the Dinpual Lepisloptera. They are very swift flyers, and are practically always on the wing. Their collection requires some degree of skill in the nse of the net. A gool method comsists in risiting, in the early morning, water courses in which the larval and pupal states are pasied, and rapturing the adults just as they issue from their pupal skins at the edges of the pomel or straim. In cold weather they are less artive and may freprently be found relinging to trees and plants, partivularly in the vicinity of their breeding plates. Maty-tlies (Ephemeride) oceur

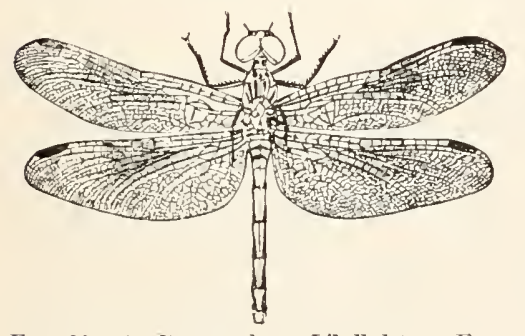

Fir: 86.-A I ragontty (Libellula). (From packaril.)

in immense

numbers near theil breading places in pouds and streams and

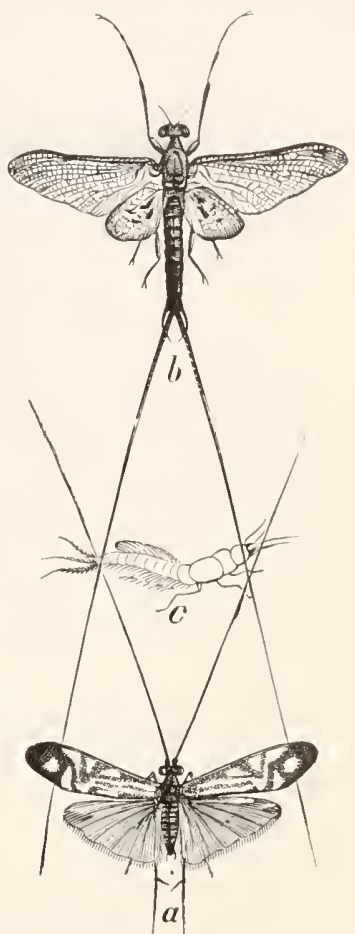

FIG. 85.-b, a May-Hy (I'alingenia bilneata); $c$, its larva; $a$, a Cadilis-tly (Wareronema zelora. (um). are also attranted in large quantities to electric lishts. Their collection is therefore an eatsy matter, but on account of the very fragile nature of these insects the ntmost ante must be employed in handling them. The early states of all the aquatic forms mentioned above may be olotained for breeding by the nse of the dip not by dragging it forcibly against water plants.

Neuroptere proper (Hellgrammites, Lace-wings. Ant-lions, Caddis-tlies, etc.) - Among the larg. est insects of this order are the Siahida, which in chules thr enormous II ellgrammite Fly. Coryolahes cormutus. The larve of this insect are carnivorons and ocenr in streams, nuder stones, etr. The adults may be enllected in neighboring situations and are also attracted to light. The Lace-wing

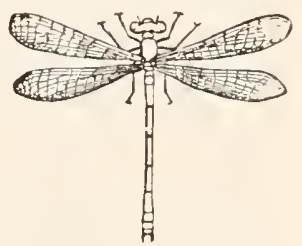

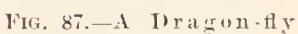
(Agrion). (From liackaril.) flies (Chrysopre), Ant-lions, ete, are carnivorous as larvie, and occur, the former anong the Aphirles which infest varions plants and the latter 
at the bottom of pits in loose, sambly soil. The adults may be obtained by general sweeping and are also attrated to light. The most inter-

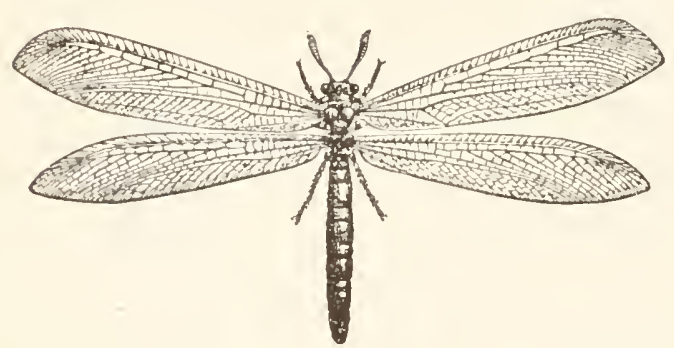

Fig. 88. - In Ant-lion, adult (Myrmeleom). (From Paekari.) asting insects of this or. der are the caddis-tlies, (1) aceount of the peraliar and frequently rery beantiflul mases i"oll. strmeterl by their larvir, which it is important to wollect. The Carddis-flies breed in pouds and lakes and the arlults maty be collected in such situations

or at light. The larva may asisily be reared, and shomld be collertal for this purpose. Most of the insects named in this order are extremely delieate and require great care in handlinge.

\section{KIJLLT ANI PRESERTING INSECTS.}

Between thre collecting of the sperimens and their final disposition in a well-atranged cabinot, a good dral of mechanical work is meressary, involving a skill and dexterity which an be thoronghly aropuired only by praction.

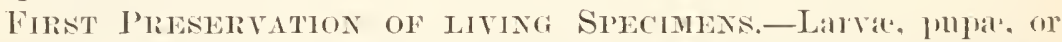
imagers intended for rearing purposes, must be kept alive, and are best

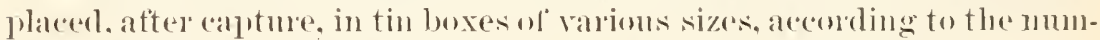
ber of specimens to be put in each and areording to the size or mature of the food plant, etc., on on in which the specinems are found. and of whele a quantity must always be taken lowme. For lawger tiu boxes those known as "seddlity powder buxes, described and figuresl below, which ean be made to order at any timners shopl, are well aldapted, and smaller tin boxes of a convenient ronud form ean be obtainesl of the

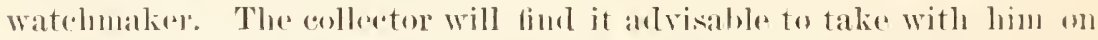

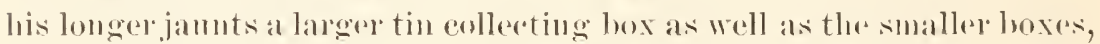
and for this pungose nothing is better than a good hotanist's collecting

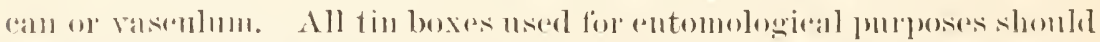

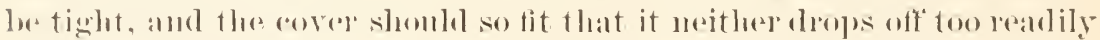

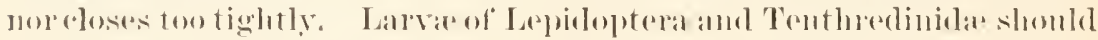
be plared in a lox with a rluantity of the leaves of the plant on which

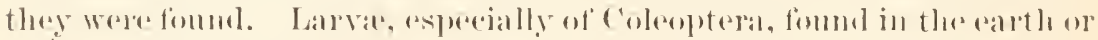
in derayed wookl. should he plared in a box filled with such ealth or

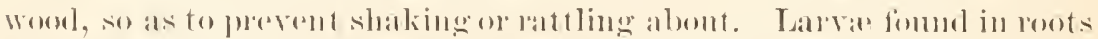

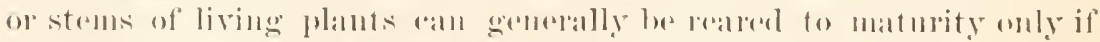

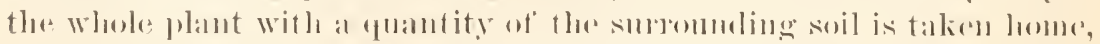

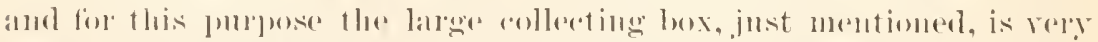

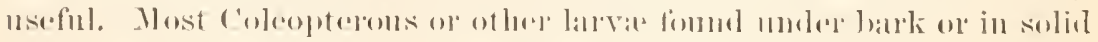

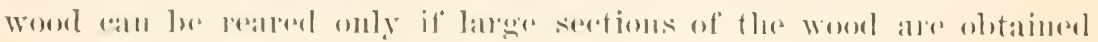


and the lalve ane full grown or mearly so. This holds true, also, of species breding in sereds and with most leat-mining specios. The greatest difticulty is experienced with carnivorons Coleopterous larve, and care should be taken with such not to inclose two or more speeimens in one box. Most larver die quickly it placed in an empty box, and this is especially true of predaceous species; so that it is always adrisable to pack the box with moist soil, lecaying wood, leaves or other similar substance. Aquatic larve shonld be rarried in tin boxes filled with wet moss or some water plant, for, if placed in corked vials with water. they dic quickly.

Killing SPECImss.-Specimens not intended for rearing should be killed immerliately after capture muless for each specimen a sejarate vial $01^{\circ}$ box "am be porided. If a mmber of miscellaneons insects are put in the same vial the strouger sperimens will, in a short time, erush or othorwise injure the more delicate ones or the predaceous species will derom any others they can master. But even where the specimns are killed immediately the following rule shonld be observerl: Do not put large and small specimens in the same vial, but provile a larger bottle for the larger specimens, and one, or still better, several, smaller vials for the medinm-sized and very small specinens. The importance of this rule is recognizer by all experienced collectors.

There are serelal mothods of killing insects, each having its own peculiar adrantages and drawbacks.

Alcohol.-The use of alcohol will, wn the whole, move the most satisfactory method of killing Coleoptera, many Hemiptera, some Nemopter"a, and lalvir of all sonts. Only the best quality of alcohol should be used, but it shomld be dihnted with from 30 to 40 per cent of pure water, the greatest care being taken to keep the alcohol as clean as possible. During the collecting a mass of débris and dirt is apt to be thrown into the bottle, and when this is the "ase the alcohol should be changed eren during short excursions. At any rate, upon the return fiom the excusion, the specimens shomld be at once taken from the bottle and washed in pure alcohol in a shallow ressel. The larve amo other material intended for permanent preservation in alcohol should be transferred to suitable vials and the material to be mounted cleansed with chloroform or acetic ether and then prepared for the cabinct. If it is inconvenient or impossible to momt the Coleoptera, etc.. soon after the betmon from the excursion they should be washer, dried, and placed in pill boxes between layers of soft paper, or they may be replacel in a vial with pure alcohol. On longer collecting trips, lasting several days or weeks, specimens will keep thus very well, provided they are not shaken up, and this can be prevented hy filling the empty space in the rial with cotton ol soft paper. If the bottle is a large one and contains many large specimens the aloohol should be renewed three or fom times at intervals of eight or ten days; otherwisc the specimens are liable to derompose. Small and delicate speci- 
mens, if they are to be kejt in alcohol, shondd be treated with still greater (are. T'pon the retum from the exrmsion they shombl also he cleaned in pme aloohol and placed in small vials into which a very few drops of alcolol, just sufficient to keep the contents moist, ane pomed. The vial shomld be corked as tightly as possible and the speceimens will keep pretty well for an indefinite time.

The drawhacks to the use of aleohol are: lst, that all bairy spereimens are liable to spoil; sudly, that all Coleoptera with soft intrewnments splearl the wing-eases apart if kept too long in it. The arlyatage of the aloohol is that it is the simplest and least tromblesome fluid for naturalists traveling in olistant comntries who ale not sperialists in entomology. Specimens killed in aleohol are also less liable to bo attarked by verdigris when pinned than those killed by some other mothod. Rum, whisky or similar strome alcoholic liquoms may lor nsed as smbstitutes where no pure alcohol an be obtained, hut ane not especially to be lecommended.

Chloroform and Ether.-Killing with the fiumes of ahloroform or ether (sulphuric or aretic) or bensine, or some other etherice oil, is often porateticed and advocated by those who, for any lasom, dislike the nse of

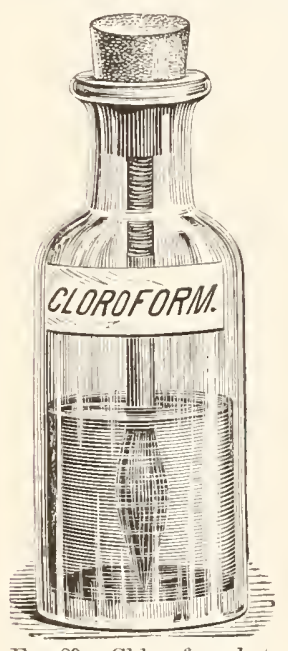

FIG. 89.-Chloroform loot tle with brusl. aleohol or objoct, on accomnt of its poisomous nature, to the use of ryanide of potassimm, and they are of espucial value in the ase of butterflirs and moths, IIymenoptera and I Diptera. ${ }^{A}$ small and stont bottle of aloloform or ethere, with a brush socurely inserted into the cork (Fig. s!) , will bo tomm very servicable. A slight moistening through the ail net will stmpefy most insects ranght in it, and fareilitate their removal to the eyanide bottle: while a tonch on two with the wet housh moler the head and thorax, will kill the mowe delicate sjerimens ontright, withont in the least injuring them. Another way of using chloroform is by meansot' a small, hollow tube passed through the eork, what is called jewroler's hollow wire answring the pmpose. The liquid rvaporates more rearlily in such a bottle, and I altogether prefer the first mentioned. Some lange inserts, amol reperially frmale moths. Whose size prevents the use of the ordiuary cyanidr bottles, are dilficult to kill. With these, fluttering may he prevented hy the use of chloroform, or they. may be killed by puncturing the thorax or piereing the body longitudi-

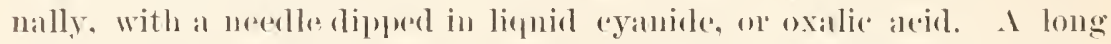
bottle with a meredle thrmst into the eork may he kept for this pulpose;

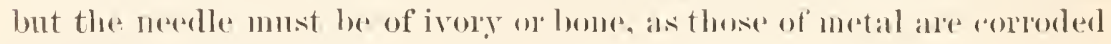
and eaten by the linguids.

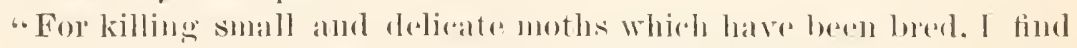

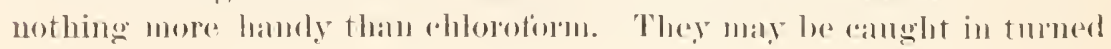


wooden boxes which are kept by every druggist; and a touch of the chlerotorn on the ontside of the box immorliately stupefirs them. It has a tendency to stiffen them, however, and they are bust set immediately after death."

A piece of heary blotting paper or heary roth soaked with chlorotorm or ether or benzine and placed at the bottom of a jar or bottle makes an excellent killing bottle for large-sized insects. For smaller specimens the collecting vial should be half filled loosely with narrow strijs of soft paper, upon which a few drops of the licpuid are ponerel. not so muel, homerer, as to wet the paper. While collecting, the vial must be kept closed as moroh as possible. Some rollectors prefer chloroform, others ether. If this methorl of killing is practiced with the neossary care, there

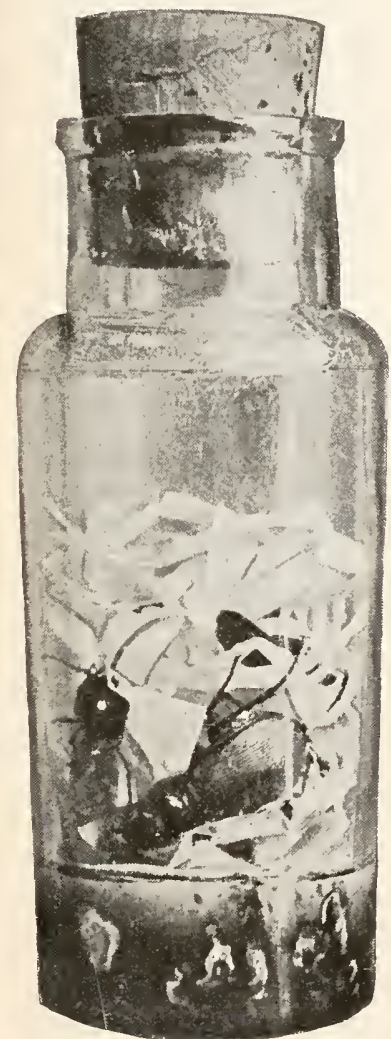

FIG. 91.-The Cyanide bottle with paper strips to give support to the insects. is no objection whaterere to it: thespecinens are not wetted as they are in aleolıol, and rematio cleaner than those killed by any other methorl. The drawbark is that the substances mentioned evaporate very rapidly and have to be lenewerl areal on short ex. cursions. On areount of this great rolatility, one can nerer be restain that all the specinens in the collecting bottle are dead after a given time and there is always some danger that one or the other of the hardier insects may regain activity. What misehief such reviven specimens are capuble of doing, many collectors have exprerienced to their sorrow. Another disadrantage of these volatile substances is that if used in too large quantitios they will, in delicate specimens, especially beetles, canse an ex. tension of the soft ligaments between the head and prothorax or between the latter and the mesothorax, and thus bring the specimen into an munatural position, or canse the head, or head and thorax to drop off'.

Cyanide of Potassium.-The methor of killing which, of late years, has fommd most favor with collectors, is the use of 'yauide of potassium. For killing large sized specimens they are simply put in what is now miversally known as the "ranuide bottle." This may be constructerl as follows:

Take a "2-onnce quinine bottle, or still better a shorter bottle with a 
wide month; break 11 ) a quantity of eyanje of potassinm into pieces of romvenient size (abont a rubic centimeter); jut these pieces in the bottle so that they form an even layer at the bottom: mix in a convenient vessel a quantity of plaster of Paris with wated just sufficient to make the mixtme semifluid and then pour it orer the ryanide so as to corer this last to a depth of about is millimeters. The bottle is then

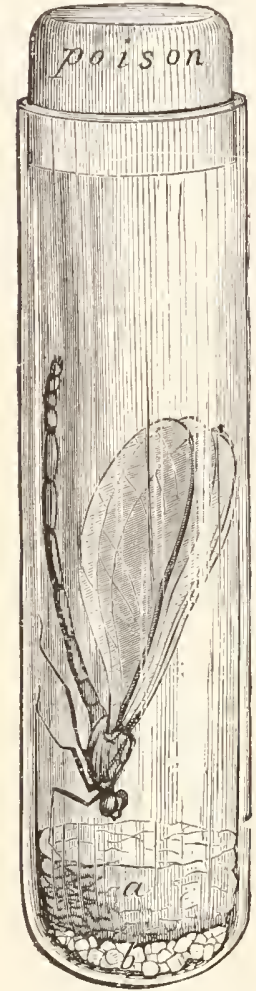

Fig.92.-Pocket eyanide loottle. loft open for an hom or two until the plaster is thorroughly dry. The walls of the bottle are then cheansed from particles of the plaster which may have splashed on them, and the bottle is ready for use. If not used too fiecuently, especially in wam weather, it will last for an entire year or longer. Bottles or vials of different sizes can be prepared in the same way, aud a very small cyanide vial which can be arried in the vest poeket will be found most comvenient for nse on all oceasions. Fig. 92 represents a unedium-sized chamist's test tube. converted into a very convenient cyanide bottle, in which, howerer, a cotton wad has been used to keep the poison in place. When the collected specimens have bern removed from the lottle the latter should be carefully wiped rlean with a piece of cloth or paper. The surface of the plaster soon becomes dirty and, on aceonut of the hygroseopic property of the ryanide, more or less moist, esperially during warm weather: The cranide bottle is, therefore, not well adapted for the killing and temporary preservation of small aud delieate specimens. This difficulty eam be altogether obviated by placing a ricental piece of blotting paper, "nt to neatly fit the interior of the bottle, on the surface of the plaster. This ean be renewed once a week or so, or oftener if it becomes necessary. It will frequently be arrisable, also, expecialiy in the collection of Diptera, Hymenoptera, and other delicate inserts, to put a strip of blotting paper partially round the immer sile of the bottle. 'This will absorb auy moistme which maly gather on the inside of the bottle and which wonld otherwise wet and injure the specinems. The areompanying figure (Fjg. 93) illustrates a bottle arranged as deseribed above. I similar lesult is attained by some coll(x.ors by partially filling the bottle with mancow strips of bibulous paper to support and separate the insects as shown at Fig. 91.

For dedioate specinens, also, the collecting bottle may eomsist of a testtulbe of about the size of Fig. 92. 'This is half filled with loose, thin strips of soft white paper. A piece of cyande abont the size of a pea is throl wapped "alrefully in paper and so plared in the middle of the strips that it can not enene in contalet with the sides of the glass. 
Some prefer to pin the paper containing the eyanide to the lower surface of the cork. The latter shonld be rather short and tapering toward its lower end. It is longitudinally perforated through its center by a

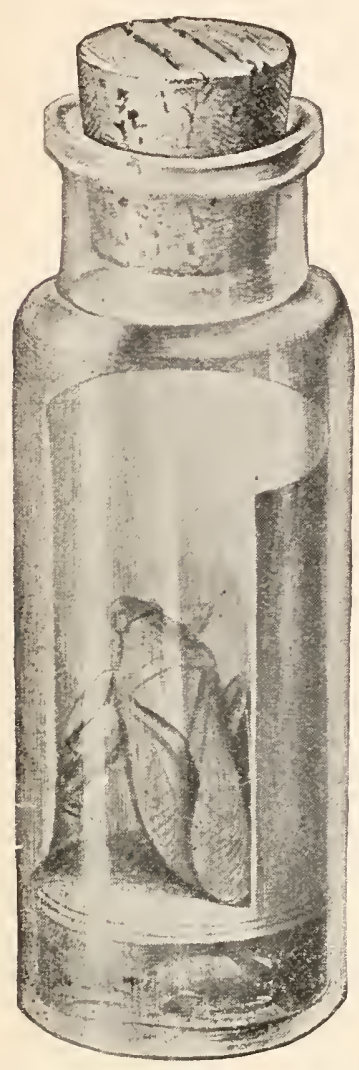

FIG. 93.-The cyanide bottle with blotting-paper lining (original). ronnd hole just large enough to insert a goose-rquill, which is cut straight at the lower end and obliquely at its upper end. By means of this goose-quill the specimens may be introduced into the bottle without taking off' the cork. This form of cyanide bottle lasts for only one day's collecting, except in cold weather, and in very warm weather it is advisable to take two prepared bottles along, so that the first used ean be stower away as soon as the cyanicle begins to moisten the paper strips. Most insects are quickly killerl in such a bottle, lout some Coleoptera must be left in for five or sis hours, while others resist death for a still longer time. This is especially true of the Coleopterous fanilies Cureulionida, Trogositillat, and Tenebrionida.

Submersion in alcohol will prove a satisfactory method of killing these or other beetles with similar vitality.

Other Agents.-Prof. E. W. Claypole has found the use of benzine or gasoline very cheap and satisfactory for killing Lepidoptera, as the largest are at once killed thereby withont injury to their seales. (Can. Ent., xix, 1. 136.) He squirts it onto the specimen within the net or in the open air by means of a druggist's dropping tube. Hot water kills rapidly and leaves the specimens in good flexible condition for mounting. The heads of large insects may be held for a few moments in the water, while smaller specimens should first be thrown into a corked bottle and the bottle submitted to heat. Where the lanrel grows its bruised leaves may be used in place of eyanicle; they kill less quickly. The leaves of the Laurel-cherry (Prumus lauro. cerusus), a plant commonly grown in England for sereens and hedges, are also used for this purpose.

Some collectors, with indifferent olfactory sense, moisten the cork of their boxes with creosote. Its killing power lasts for sereral days. A few whift's from a eigar, when nothing else is at hand, will also kill many of the more tender insects.

Special DiRECTIONS FOR DIFFERENT oRDers. - A few brief directions for the special treatment of different orders may be given. Cer. 
tain Coleoptera, notably those of the Cureulionid genus Lixus, are corered with a yellowish pruinosity resembling pollen, which is of an evanescent nature, so that it the specimens are collected and killed by the ordinary methods, the pruinosity is completely lost. To preserve the natural beauty of such species it is necessary to put each specimen alive in a small vial and to kill it at once by means of a lighted mateh held molur the vial for a fer seconds. In pimning or otherwise mounting the specimen it shonld not be handled between the fingers.

Many ITymenoptera and Lepisloptera, especially species with yellow markings, if kept for any length of time in a cyanide bottle, will become discolored, the yellow changing to reddish, and hence such insects shonld not be left longer than_necessary in the bottle. If care is exercised in this respect, no danger of discoloration need ordinarily be feared. The chloroform collecting bottle may be used with these insects if discoloration is anticipated. All the nore delicate inserts, inchaing Hymenoptera, Diptera, the small('r Lepidojtera, and the Neuroptera, require special care in killing. Large numbers should not be thrown into a killing bottle together, and plenty of bibulous paper should be kept in the bottle to prevent moisture from accumulating and wetting and ruining the specinens. It is frequently advisable to pin Diptera, especially the hairy forms (as the Bee-flies), in the net and transfer them at once to a cigar box containing a sponge moistened with chloroform. When the collecting shears are userl, the insects are always thus pimned at once, which is, in fact, the only methor of securing them. This is also neressary in the case of many Lepidoptera. Delicate Neuroptera may be killed by the use of the cyanide bottle, or, preferably, placed at once in a vial of alcohol, as these insects, in many instances, camnot be kept securely if pinned or monnted. Large Lepidoptera, as the Bombycids, may be killed by powing benzine, naphtha, or chloroform over the thorax and abdomen. These substances evaporate rapidly and do not appreciably injure the restiture of the insects. Some collectors, in the case of butterflies, seize them dexterously between the thumb aud finger, and give a sharp pincl on the sides of the thorax. This will prevent the flnttering of the insect when transferred to the cyanile bottle, and, if carefully clone, the scales need not be rubber off. It is objectionable, however, hecause the thorax is distorted and subsequent anatomical study interfered with, and, in the case of moths, should never be practiced, as the thorax affords important characters used in classification. Orthoptera ma be killed by the use of the cyanide bottle but should be transferred at once to the vials of alcohol. If placed in a cyanisle bottle, especially in the ease of Locusts (Acridide); they are apt to exule colored juices from the mouth, so that the speeimens hecome soiled. Hence the use of vials of alcohol is preferable, and these insects should never be thrown into vials rontaining delieate insects of ofher orders. P'ant-lice, together with the plant which they infest, should be placed at once in vials of alcoliol, 
and speeimens of the Aphides, representing all the forms present, should be mounted on slides for microseopic examination. The fixed forms of Coceids, comprising the majority of the species, require no special treatment, and the leaves, twigs, or bark ou which they orcur may be pinued at once and placed in the eollection. The free forms are treated as in the case of plant-lice.

\section{ENTOMO'TAXY.}

Under this term may be considered the preparation of insects for the cabinet.

CARE OF PINNED AND MOUNTED SPECIMENS.

Insect Pins.-In mounting insects for the cabinet, expressly malle entomological pins should be nsed. These come from three different sources: Kläger pins, made by Termann Kläger, Berlin, Germany; Karlsbad pins, mate by one or several firms in Karlsbad, Bohemia, Anstria: and Vienna pins, made by Miller, Vienna, Anstria.* These three kinds of pius have each their own slight adrantages and disadrantages, so that it is difficult to sar mein the liest. All have the disadvantage that the pinned specinems are liable to be ruined by verdigris, and to obviate this jatpanned ("batek") insect pins ane male by Klïger and Miller. These black jins are, lowever, much softer than the "white" pins, and therefore more rifficult to handle. A pin of 35 millimeters in length will be fomm most convement for pimning all insects exeepting the larger Lepirloptera and other heavy-borlied insects, for which a longer pin may arlvantageonsly be used. Aceorling to the different degrees of fineness, the pins are numbered firom No.00 (the finest in the trade) to No. 7 or 8 , but the numbers nsed by the different manufacturers do not eorrespond with eareh other. In experience, pins of Nos. 1, 2, 3, and \pm (Kläger numbers) are more often needed than the others. The long pins of the finer numbers (Nos. 0 and 00 ) are difticult to handle in the collection and, for this reason, not to be recommented.

For many small insects, especially Microlepidoptera and Microdiptera, which must be piuned, even the finest ordinary insect-pins are too large, aud two special makes of pius are in use for this purpose. The "clbow pin" (formerly made and sold by Dr. Knenow, of Kïnigsberg, Prussia, Germany) consists of a piece of fine silver wire, pointerl at one end, and with a coil loop at the other end, into which a longer pin (No. 3 or No. 4) is thrust. This pin is illustrated in Fig. 94. Still more satisfactory are the "Minutien-Nadelu" (pins for minnte insects) manntartured by Mr. Miller, of Viemua, Austria, and which consist of a straight piece (about $14^{\mathrm{mm}}$. long) of extrenely fine steel wire which is pointed at

* In North America, Kläger pins and Karlsbarl pins can be obtained tlurough Mr. John Ackhurst, 78 Ashland Place, Brooklyn, N. Y., and possibly also thronglı Messis. Blake \& Co., 55 North Seventh street, Ihilarlelphia, Pa. The Vienna pins and the Minutien-Nadeln have to be ordered direct through the mannfacturer, Mr. Miller. 
one end, and which is nsed in comnection with a piece of pith or cork.

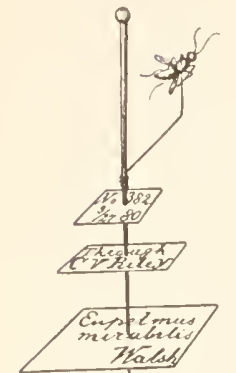

FIG. 94.-Insect mosunted on "el bow-pin."

The mode of using this pin is shown in Fig. 101. These fine and elbow pins may be obtained either "white" or. japammed.

"Many Lnglish entomologists nse slort pins, very murblike those of ordinary make, and my late fiend Walsh never gave up the custom, and most vehemently opposed the usc of what he riliculed as 'loug German skewers, But the only advantage that can possibly be "laimer for the shout pins is that they are less apt to bend, (enserfuchtly more easily stuck into the bottoms of boxes, and require less room: while, compared with the long pins, they have numerous disadvantages. Long pius aldmit of the very important advantage of attarhing notes and labels to the specimen; render it more secure from injury when handled, and from musem pests in the cabinct; and on them several rows of carded duplicates may be fastened, one muder the other, so as to economize romm."

I have seen few old collections in better condition than that of the late E. Mulsant, of Lyous, France; and he used iron wire, eut slantingly, of the requisite length-at common custom in France. These wires bend so easily and have such dull points that they require much more careful manipulation than the pins, and the raim made for them that they do not verdigris would, perlalps, be offset by their rusting in moist elimates or near the sea. Silvel wire or silver-plater wire is also used.

Preparation of Specimens.-Upon the return from an excusion the specimens shonld be prepared for the collection as soon as practicalble. If they have been collected in the forenoon they shomld be mounted the same evening, and those collected during an afternoon or evening excursion should be mounted the following morning, or, at any rate. before they get dry and brittle. Even specinens collected in alcohol should be attended to as soon as possible.

Specinems are taken fom the collecting bottle, spread out on a sheet of white blotting paper and releared from alloring impurities either with a soft dly hrush, or, in the rase of speeies wath hard roveriug, by washing them with rhloroform of ether or benzine where neressily. Theoretically the best way of monnting would be to pin all suecimens, since the under sisle with its important ohameters then remains foee for examination. Pins adapted fin pimming even the smallest insoets have been described above, hot this piming is smoh a delicate operation and repuirs so much time that romsidering the large mumber

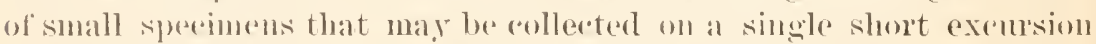
it is mext to impossible to an'y ont this methorl, and therefore only the

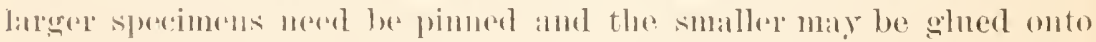

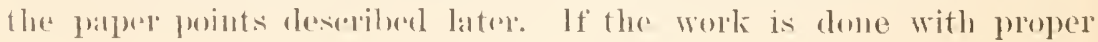


care all insects can be prepared for the cabinet so that both the mpper and under surface of the specimen may be examined withont finther manipulation.

Pinning. - "Insects shonld be pinned throngh the middle of the thorax, when, as is more generally the case, this portion (the mesothorax) is largely developed. Beetles (Colcoptera) and Bugs (Hemiptera), should, however, be pimed, the former through the right elytron or wing-cover (Fig. 95), and the latter through the scutel or triangular piece behind the thorax, the pin issuing between the middle and hind legs (Fig. 96). The specimeus look very pretty with all the legs neatly spread out, but for practical purposes it is better to let them fry in the natural, partly bent position. It is a saving of time and space, and the limbs are not so apt to break. The legs

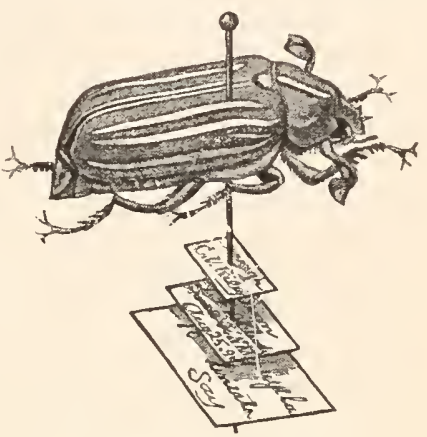

Frg. 95.-Method of pinuing and labeling Coleoptera (original). must also not reach too far downward or they will interfere with the proper labeling and the secure pinning of the specimen in the cabinet Moreover, the antennat and legs must be brought into such position that they will not obstruct the view of any important part of the under.

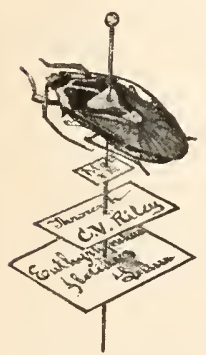

Fig. 96.-Met hod of pinuing Hemiptera (original).

surface. The pin should always project about half an inch above the insect to facilitate handling, and uniformity in this regard will have much to do with the neat appearance of the collection. In pinning very large and heavy iusects on a No. 4 or No. 5 pin, it is a good plan to first flatten the pin by a few blows of a hammer, in order to prevent the specimen from subsequently turuing round on the pin."

In pinning specimens which have a flat or nearly flat molersurfice and short legs (as in many Coleoptera and Hemiptera and some Hrmenoptera, e. y. the Sawflies) the specimens are laid on a piece of cork and held in place there with the finger's or with a foreeps. The pin is then pushed through the insect at the proper point, care being taken not to strike one of the legs or coxat, and that the pin passes throngh the specimen in a vertical direction.

After the pin has been pushed through the specimen it is taken ont of the cork and the specimen is pushed up to its proper height. This can be done either by holding the specimen between the finger's or by placing it on the rpper edge of a thick book. A piece of cardboard provided with a small hole may also be used for this purpose. The perforations in ordinary sheet-eork, or the lapel of onc's coat, will answer the same purpose. In pinning Lepicioptera or Hymenoptera the specimen should lie lightly in the angle formed by the thrmb and 
first two fingers of the left hand and the pin be carefully thinst through at the proper angla. In pimuingall insects the pin shonld be so inserterl that the insect is nearly at right angles with the pin, the josterior end being slightly depresserl.

Woanting on Points.-Most insects which are too small to be pinned (on a To. "2 pin may be fastrued to candboard by means of gon tragacanth, gum shellar, or any good glue. It is not always easy to determine whether to pin a medimm sperimen or te glne it to a triangle. Pinned sperimens are moro secmer, and not sil apt to fall or be knocked off; but they are liable to become comoled by verdigris and ultimately lost, aspecially in familios the las of of whel are endopleytous or internal teeders. It is better to glne wherever there is doubt. A rrop of rol'rosive sublimate adderl to the water in which the grm tragacanth is disisolved will indefinitely prevent its soming, but should not be nsed where the gum is to rome in rontart with the pin, as it inclines the latter to verdiglis. In smeh cases a little sporits of camplon mixed with the gum tragacantl is best. S'lellace shomld be dissolved in alcohol and this remuires some time. This glue is not affecterl by moistme, and if it is desired to remove the sperimens, they must be immersed in aliohol nutil the shellac is agan dissolvad.

A number of different kinds of glue are used by entomologists. The repuiremests of a goud glue are that it be rolenless, and, what is of greater importance, that the spreimens adhere firmly to the paper points so that there is little or no danger of their being jarred oft'. Those glues which are realily soluble in eold or lukewarm water are perlaps more conveniont than those which require alcohol or chloroform for dissolving. Gum arabie and gum tragacanth lave the disadvantage that they are more liable to attract mites and are more brittle. so that they do not lobl specimens as well as some of the liquid glues that aro on the market. Spalding's glue answers a very goof purpose, as also the proparation known to Enropean entomologists as Leprienr's gum. White bleached shellae, while requiriug alcohol to dissolve it, has the advantage that a very minute quantity suftices. In olden times thr method employed was simply to glne the specimen by the rentral side to the middle ot a quadrangular piece of ardboard, which was then pinned on a No. $30{ }^{*}$ No. 4 inseret pin. This method is still in vogue with English entomolugists. but can not be recommended except for momenting duplicates. Much better are the small isosceles triangles which, before monuting the sjecimen, are piumed through near the base ou a No. "2 ol No. : insert pin. Only the best and tinest calrelbond shenlel be userl fore this purposes since that of poor quality is liable to be broken while passing the pin thromgle it and will yellow with age.

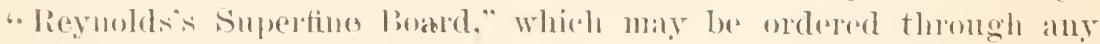

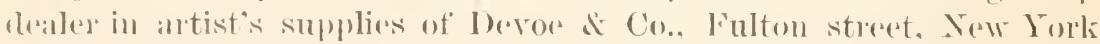

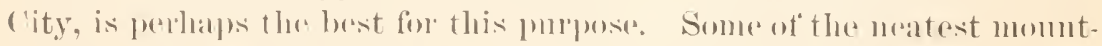

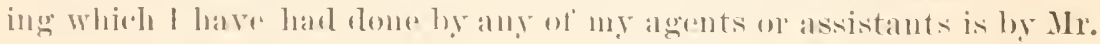


Albert Koebele, who has used mica or gelatine instead of cardboard, the object being not only to show the whole of the under side of the specimen, but to obserure less of the light from the labels and to render the triangles less conspicuous in the eabinet. These have been in nse in the musemu collection only for the last two or three years, and whether they will eventually tend to corrode the pins is not yet sottled. Mica and isinglass are also nsed for the same purpose. The points used in mounting may easily be cut by hand to a convenient size, say onefourth of an inch (6-8 $\left.{ }^{\mathrm{mm}}\right)$ long by one-sixteenth or less at the base, and tapering to a point. The point may be namower or wider to accommodate insects of different sizes.

For cutting these triangles or points, various forms of punches similar to the appended figure (Fig. 97) known to the trade as conductor's punches may be used, and points thus cut are to be preferred to those made by other means, on aroount of the greater uniformity secured.

An experienced hand, however, will 'ut these points very rapidly and accurately with a pair of shears, and most collectors use no special instrument for this purpose.

The punches mentioned may be obtained of the manufactrirers* of such instruments at from $\$ 2$ to $\$ 3$. Care should be observed in ordering to state explieitly the length, wilth at base and point, or, what is better, to inclose sample of the size of point it is desired to cut; but above all, to state that the bloek of paper to be cut out is the result desired, and that the instrument should eut clean and eren, with no ragged edges.

For monnting different forms and sizes the fasticlious collector uses four or five sizes of points. but for all practical pul'poses one to cut a card point not less than $1.3^{\mathrm{mm}}$ at the base and prolonged as nearly as possible to a point, and another

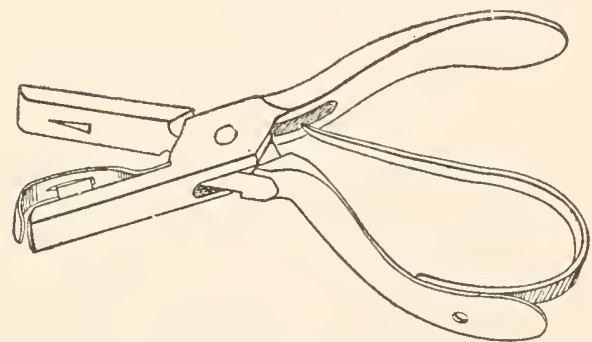

Fis. 97.-Insect punch for cutting triangles or points (original). a trifle wider at the base, say $1 \frac{1}{2}$ or $1 \frac{2}{3}{ }^{\mathrm{mm}}$ and with a point abont $1 \frac{1}{2} \mathrm{~mm}$ in widtlı will suffice.

For mounting most long-bodied insects, e. g., Staphylinidie and

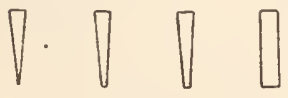

$\begin{array}{cccc}a & b & c & d \\ \text { FIg. 98.-Points for mounting }\end{array}$ insects (original). Elateridie, an oblong card say $1 \frac{1}{2}$ mm in width is desirable. With a little care these may be cut with suffieient uniformity with scissors. Seven and one-half millimeter's may be taken as a standard of length, as this is about the size used by the majority of our best collectors. Shorter points, say $6^{\mathrm{mm}}$ or one-quarter inch long, are sometimes preferred, where economy of space is a desideratum. 
A series of four points of different sizes for mounting insects is shown in the aceompanying illustration. The sharp-pointed one, $a$, is designed for the minntest forms and the larger points for large insects. The largest should be nomnted on points of a nearly rectangular shape, shown at $d$. The dimensions of these points as adopted by most entomologists, are as follows:-

\begin{tabular}{|c|c|c|c|}
\hline & Length. & Breadti. & l'oint. \\
\hline 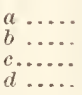 & $\begin{array}{l}7.5 \mathrm{~mm} . \\
7.5 \\
7.5 \\
7.5\end{array}$ & $\begin{array}{l}1.5 \mathrm{~mm} . \\
1.5 \\
1.5 \\
1.6\end{array}$ & $\begin{array}{l}.0 \mathrm{nmm} . \\
.4 \\
.6 \\
1.6\end{array}$ \\
\hline
\end{tabular}

The point or triangle shonld be nomuted on the pin and directed to the left, the height fiom the top of the pin varying somewhat with the

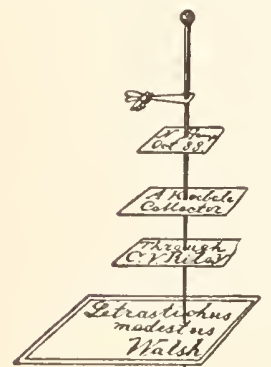

Fig. 99.-Insect mounted on cardboard triangle. specimen, but averaging about one-half an inch. The insect is then glned to the point with the head pointed forward. In the case of Coleoptera and Hymenoptera, and in fact of most insects, the specimen is mounted with the back nppermost, but in the case of the smaller Hymenoptera it is advisable to mount some of the specimens, at least, on the left side (see Fig. 99). This directs the legs toward the pin, as a matter of safety, prevents their being broken in handling, and also gives opportunity for subsequ('nt examination of the back, side, and venter of the specimen. Coleopterists always monnt specimens on the venter, and in the case of a correctly monnted specimen the whole undersicle of the body should be available for examination except the right half of the metasternum, as shown in figure 100.

In mounting minnte insects a few preeantions are necessary. The beginner usually uses too much glue or shell-lar, and the result is that the momnted specimens are more or less covererl with the flnid, so as to render them unfit for examination. If, on the other hand, too little of the glue is used, the specimens are not securely fastened to the paper point, and are liable to be jolted off by the slightest jar. Before momting specimens the legs and antemuc must be brought into the proper position by means of a hrush or with a dissecting neerle, so that they may a asily be seen. A supply of paper points should always be at laud, and after selecting one of the proper size for the specimen, with an arute

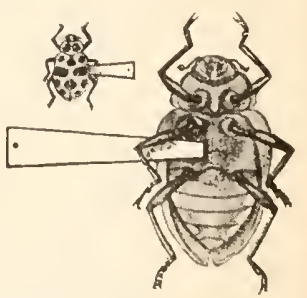

Fig. 100.-Method of gluing beetle on paper point (ori(rinal).

tip for a very small specinen and with a mole obtuse point for a larger one, a small quantity of glue is applicel to the tip ly means of a pointed stick, such as a toothpick, the amomut varying with the size of the specinen. The tip of a moistened brush may be usad to transfor the 
sperimen to the point, or one will soon become dextrons enough to do this withont the aid of the brush. The specimens are then allowerl to dry in a horizontally placed box. If the drying box is placerl in a vertical position the specimens, especially long-bodied ones, are liable to topple over before the glue has become firm.

Delicate flies and Mierolepidoptera, which it will not do to fasten with nuncilage, may first be mounted on the fine pins described above and these thrust into oblong or triangular bits of pith or cork, which are momited on larger pins as shown in Figures 101 and 102. This affords a very satisfactory method of mounting, particularly as the different sexes may be brought together on the same bit of pith, or the adult and puparium in Diptera, as shown at Figure 101. Strips of stout cardboard with the pins rum through the narrow edge may also be nsed. The method of mounting minute Пymenoptera and Diptera and other inseets on a bent wire, men-

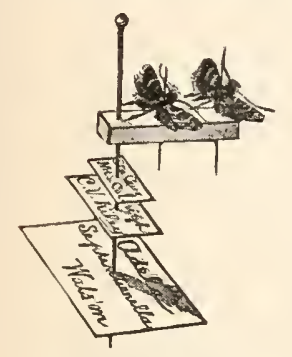

Frf. 102.-Micrulepidoptera mounted on pith (original). tioned above, is illustrated at Figure 94. This method las not

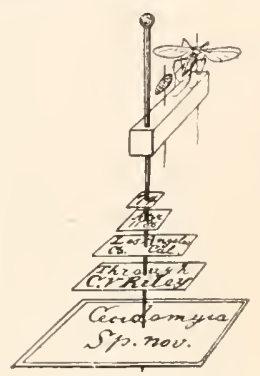

Fig, 101.-Cecidomyiid mounted on pith (ori. ginal). proved so satisfactory, as the wires areapt to lweme loose on the pin.

Mounting Inuplicates. - If the collector finds more specinens of a rare species than he cares to have in lis collection, the excess may be monnted as dupli. cates. If the species happens to be of a linge size the specimens are pinned in the ordinary way, but if small enough to be gummed, there is a most convenient method of rapidly monnting the specimens so that they may be sent through the mail with much less risk of gettingbroken or knocked off than if glned on paper points, aud will also take up rery little room in the duplicate boxes. It consists in glning the specimens in a transverse row on a strip of white card paper with one of the glues soluble in water, care being taken that between the individnal specimens some space be left, and further that the heads and antemne dn not project beyond the alge of the paper. The wirth of the paper strip must be somewlat

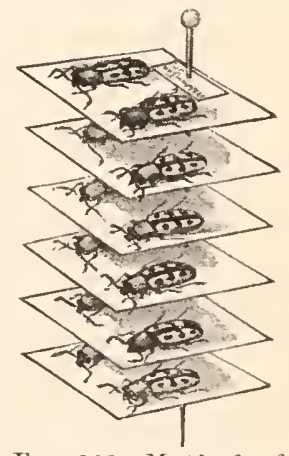

Fig. 103.-Method of mounting auplicates (original). greater than the length of the specimen, so that bolow the latter there is sufficient roon for inserting a pin throngh the paper. After the glue has become dry the row of specimens is ent with scissors into sereral smaller rows of convenient size, so that on eacle of these rows there are two or three or more specimens, according to the size of the speeies. A locality label is pushed high up on a To. $_{3}$ or No. 4 pin. and one of the momterl rows of sproimens is then pinned and pusherl np 
near thr locally hahel; a second row is then pinned and pushed near the first row, and the same process continued with the third row and so on. A single pin will thus bear five or six rown, and in giving away or sembling away specimens the lowest row is taken from the pin and repinnerl for mailing. The acrompranying figure (Fig. 103) illustrates the monuting of a moderate-sizen species in rows of two specimens earh. This methor of mounting duplicates may be arlopted not only for Coleoptera, but also for Heteroptera, Homoptera (excepting Aphididie and allied fimilies), smaller Orthoptera, and Hymenoptera. It is, howerer, impracticable for Lepidoptera, Diptera. and most Nenropitera.

Temporary Stomege of specimens.-If the entomologist is prevented from monuting his captures soon after returning form an expedition, or it, on extencled collecting trips, time rloes not offir for this pmpose, spreimens of almost all orders except the Lepirloptera, Orthoptera, and Nenroptera may be placed in a small, tightly closing pill box, care being taken to keep the larger specimens apart from the small ones. In this way specimens will keep for an indefinite period, provided they are properly packed. In the ase of the traveling collector, where the material is to be carried from point to point at great risk of breaking, sperinens should be packed rery carefully to prevent any sliaking or rattling abont in the boxes. This may be done by placing a round piece of soft paper on the top of the specimens in the pill box. This paper should be gently presser down and the empty space above filled with other layers of paper or with cotton. The packing of specimens between cotton is not recommended, as it is a diffirult and tedions task to afterwards free them firm the adhering fihers. Layers of soft paper or, yet hetter, velvet, are preferable.

Envelopes for Lepidoptera, etr.-On an extrended trip), it will be found impracticable to monnt and prepare insects requiring cumbersome apparatus for speraling, as Lepidoptera or Neuroptera, and a veryexcellent plan onsists in folding the wings of the insect so that the lower surfaces come together and then placing it in a triangular envelope, as shown in the accompayins illustration. The collector should be provided with a quantity of paper of the repuisite dimensions for making these envelopes, and specimens, as they are taken firom the eollecting bottle, may be rapidly inclosed in them, labred, amb pardierl away in a tight wooden (not tin) box containing a supply of naphthaliue, the" spereimens thus oremplying the minimum

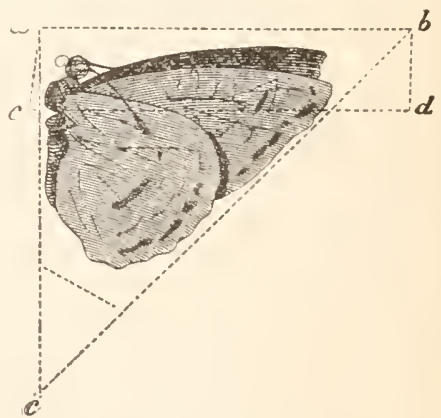

Fig. 104.--Method of preserving Diurnal Lepidoptera in paper envelopes. (Aftir. Kirsenvetter.)

of spare. Sperimens secured in this way may be kept withont fouther manipulation indefinitely on until time is fomml to relax and sot them. 
This is also an excellent method of sendiug dimmal Lepidoptera and Dragon-flies thromgh the mails and is preferable in some resprests to mailing sperad specinens.

Directions for spreading Insects.- - For the proper spreading of insects with broad and flattened wings, snch as butterflies and moths, a sprealing bobud ol stretcher is necessary. One that is simple and answers "rery purpose is shown at Fig. 10.5. It may be mate of two pieces of thin whiteword or pine board, fastener together by brates at the (ends, but left wide enomglı apart to aduit the borlies of the insects to be spreal; strips of (o)rk or pith, in which to fasten the pius, may then be tacked or glued below so as to covar the intervening sirace. The braces must be deep enough to prevent the pins from tonching anything the stretcher may be laid on, and by attarhing a ring or loop to one of them the streteler may be hung against a wall,

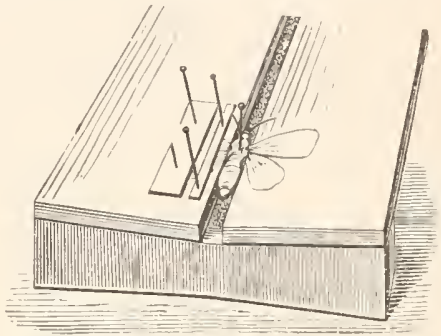

Fig.105. Spreading board for Lepidoptera. ont of the way. For ordinary-sized specimens I use boands '2 feet long, 3 inches wide, and $\frac{1}{3}$ inch thick, with thee braces (one in the middle and one at each end) $1 \frac{1}{2}$ inches deep at the ends, but narrowing from each end to $1 \frac{1}{6}$ inches at the middle. This slight rising from the middle is to comnteract the tendency of the wings, howerex well dried, to drop a little after the insect is placed in the arbinet. The wings are hold in position by means of strips of paper (Fig. 10.i) until dry. For stretehing the wings and for many other purposes, a landled needle will be found useful. Split off, with the grain, a piece of pine wood 3 or 4 inches long; hold it in the right hand; take a medium-sized needle in the left hand; hold it upright with the point touching a walnut table, or other hardgrained wood, and bring a steady pressur' to bear on the pine. The head of the needle will sink to any required distance into the pinc, which may then be whittled off, and yon liave just the thing you want (Fis. 106). To obtain uniformity in the position of the wiugs, a good rule is to have the inmer margins of the fiont wings as nearly as possible on a stragigh lime. When the specinens ale thownghly stiff and fry, they should be taken form the streteher and kept for several woeks in the drying lox before heing permanently placed in the cabinet. The drying box is simply a box of any required dimensions. contaninge a series of shelves on which to pin the spevinens, and without a

solid back or fiont. 'The back is rovered on the inside with fine

Fig. 106 , Nefdle for spread. ing in. sects. ganze and on the ontside with coarser wire, and the door in front consists of a close-fitting frame of the same material, the olject being to allow free passage of air, but at the same time to kerp ont dust and prevent the guawings of mice and other animals. The shelves should 
be not less than 2 inches deep, and if made in the form of a quadrangular frame, braced with two cross-pieces on which to tack sheet cork, they will serve for the donble purpose of drying spread specinens and for the sprealing of othors, as there are many insects with long legs which are more conveniently spread on such a board, by means of triangular pieces of stiff carlboard braces or 'saddles,' than on the stretcher aheady described. Two of these braces are fixed on the setting board, by means of stout pins, at sufficient distances apart to receive the hody between them. The wings ane then sprearl upou them and kept in place until dry by means of adritional braces. In the case of bees, wasps, ete., the pin may be thrust well into the cork $01^{*}$ pith so that the wings may be arranged in the proper position and braced and smpported by strips of stont cardboard. This method is especially recommended in the case of the Fossorial wasps, the legs of which, if mounted in an ordinary spreading board, can not be properly arranged.

In spreading Lepidoptera I have used, in thie place of a number of paper strips pimued across the wings, blocks of glass of varions sizes to hold the wings in position. My method of mounting, with a large amount of material on hand to be attended to, consists in piming a row on the spreading-board and fixing the wings in position with spreading needles, fastening them with a single narow strip of paper plated next the body. The entire spreading-board is filled with specimens in this way, a single long strip of paper on either side answering to keep the wings of all the specimens in position. Then, instead of pinning additional strips to hold the wings flat and securely in position, the pieces of glass referred to are used, placing them on the wings of the insect. With the use of glass the spreading-board must always be kept in a horizontal position and must never be disturbed. The arlvantage of the glass is that the wings ean be seen through it and more truly adjusted.

Spreadiug-boads may bo made as described above, or it may be of advantage, when a good leal of work is to be done, to adopt a somewhat different method. Five or six spreading-boards may be made together, forming a sort of shelf. A number of these shelves may be constructer and the whole combined in a case with a screen cover to exchde insects. The individual shelves may be arranged with glwoves to slide on tongues in the side of the ease. A sereen-covered case for spreading-boards is always desirable, as the insects are otherwise very liable to be eaten by roarches or other insects. I sprearling-case of the form described is shown at Fim. 107 .

A new Apparatus for Spreading Hicrolepidoptera.-For the spreading of Microlepidoptera my asisistant, Mr. Theo. Jerganile, has devised an alphatutus, leperesented in the acempanying illustration, which he finds very convenient. It consists of a small sprealing-block represented at 
$B$ and the snpport with attachment shown at $A$. The former is made in a long strip of the shape shown in the illustration, having a square groove, $c$, cut in the top. Over this is glnerl a thin strip of wood, $b$, say $\frac{1}{8}$ inch thiek, and a narrow slit is sawed in the center of this above, cutting through into the groove $c$. This is then sawed mp into pieces of uniform length, say $1 \frac{1}{2}$ to 2 inches, and the block is completed by the insertion of a rectangular

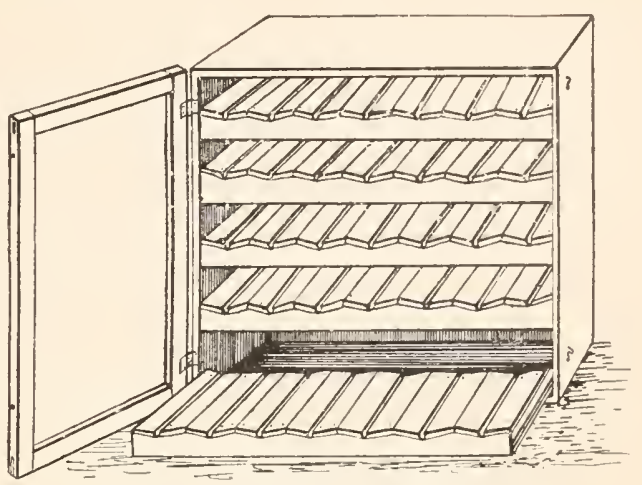

FIG. 107.-Spreading-case (original). strip of pith or cork into the groove. The Miero is pimmed on a short black pin, and the pin is thrnst down into the narrow opening made by the saw and is held firmly by the pith or cork. This block is then slid into the groove in the setting-board $A$, which narrows slightly fiom $e$, and pushed along nutil firmly sermed $(d)$. The operator can then rest his hands and arms on either side of the support, and, if necessary, bring a large hand lens over the object by means of a support with balland-socket joint shown at $e$. The wings may thus be easily and acenrately arranged and fixed in position with pins or strips of paper, as in the ordinary momting of such insects. Two or three specimens may

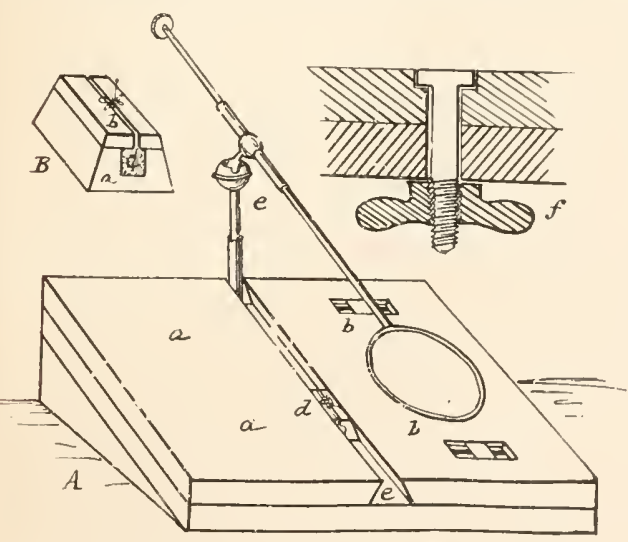

FIG, 108.-Spreading apparatus for Microlepinloptera (original).

be mounted on each of these blocks. The construction of the support is indicated in the amexed drawing. One side is attached by rlamps, shown enlarged at $f$, which afford means of adjusting the width of the slit in which the small sawed blocks slide and correct the shrinking or swelling which may take place in moist or dry seasons. The adrantage of the apparatus is that the operator has the setting block firmly fixerl before him and has both hands free to manipulate the wings of the insect in addition to having the lens in a convenient position, the use of which is necessary in the preparation of the very minnte forms.

Spreading Microlepidoptera.-The mounting of Miscolepidoptera is about the most delicate work in entomotaxy, and I can not do better 
than quote the explicit directions given by Lord Walsingham on tho* subject.

Returning to camp I put a few drops of lipnisl ammonia on a small piece of sponge and place it in a tin eanister with sneh of the boxes as do mot contain the smallest species, and put these and the remainder away until morning in a cool place. In the morning 1 pepare for work by getting wnt a pair of sejssors, a pair of foreeps. my drying-hox containing setting-boards, a sheet of white paper, and some pius.

First, I rut two or three narrow picees of paper from 3 to 6 lines wide, or rather wider, according to the size of the largest and smallest speeimens l have to set. I then double each of these strips and eut it $n$ into braces by a mumber of oblique ents. Now I tum ont the contents of the eanister and damp the sponge with a few drops of fresh ammonia, refilling with boxes containing live insects. Those which lave been taken ont will be fonnd to he all dead and in a beantitully relaxed condition for setting. Had the smallest specimens been placul in the canister over night there would have bee'u some fear of their dryiug np, owing to the small amonnt of moisture in their hodies.

If the weather is very hot there is some danger of killed insects beroming stift while others are being set, in which case it is better to jin at once into a damp rork box all that have ben taken out of the eanister, hut unler orlinary circumstances I prefer to pin them one hy one as I set them.

Taking the lid off' a box, and taking the lwx between the finger and thmmb of the right land, I roll ont the insert on the top of the left thumb, supporting it with the top of the forefinger and so manjulating it as to bring the head pointing toward my right hand and the thorax mppermost. Now I take a pin in the right hand and resting the first joint of the middle tinger of the right against the projecting point of the midlle finger of the left hand to avoil musteadiness, 1 pin the insect obliquely. through the thickest part of the thorax, so that the heal of the prin leaus very slimbly forward orer the hear of the insect. After passing the pin far enough through to bring abont one-fourth of an inch ont bolow, ${ }^{*}$ I pin the insect into the midlle of the groove of a setting board so that the edge of the groove will just sup)port the muler sides of the wings elose mp to the body when they are raised npon it. The hoard shonld he ehosen of such a size as will permit of the extension of the wiugs nearly to its miter edge. The prosition of the pin should still be slantine a little forward. The wings shond now he raised into the position in wheld they are intended to rest, with especinl care in doing so not to remove any scales from the surface or cilia of the wings. - Ealch wing shomld be fastened with a brace long enongh to extend across both, the braces being pinned at the thick "nd, so that the head of tho pin slopes away from the point of the brace; this canses the braces to prese nore firmly down on the wing when tixed. The inseet should he braced thes: The two braces next the bouly should have the points upwards, the two onter ones pointing downwards and slightly in wads towads the body, and eovering the main portion of the wings besond the middle. Antenua should he earetilly laid back alove the wings, and braces shomlt lie lat, rxereising an even pressure at all proints of their surfare. The fore wings should slope slightly forwarls su that a line drawn from the point of one to the print of the other will just miss the head and palpit. the hind wings shmbld be cluse np, leaving no intervening space, hut just shewing the upener angle of the wing evenly on each sisle. I 'an give no more precise directions as fo how this desimble result may most simply and sperdily be attained; no

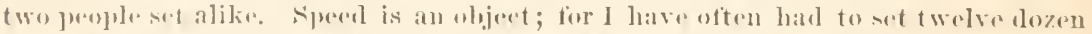
inserefs lufore hrealifist. A simple proeess is essential, for a man whe is always joinning and moving pins, and rearranging wings and legs, is sure to remore a certain mumber of soles and spuil the apluraranee of the insect, besides utterly destroy-

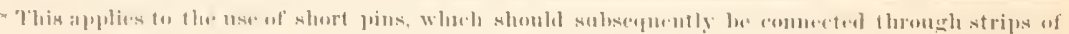

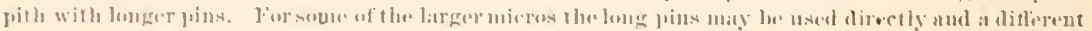
Aprealing loasd r.mployed. 
ing its ralue. I raise each of the fore wings with a pin, and fix the pin against the inner malegin so as to kerp them in 'position while I apply the brares. Half the battle is really in the pinning. When an insect is pimed through the exact penter of the thorax, with the pin properls sloped forwarl, the body appears to full naturally into its position on the setting board, and the muscles of the wings being left free are easily direeted and secured; but if the pin is not put exactly in the middle it interferes with the play of the wings. Legs must be placed close against the bouly or they will project and interfere with the set of the wings. I'ractice, rare, and a steady hand will succeed. When all the insects that have been killed are set the contents of the canister will be fouml again leady, twenty minutes being amply sufficient to expose to the fumes of ammonia. Very bright green or pale pink unsects should be killen by some other process, say chloroform, as ammonia will aftect their colors.

Insects should be left on the setting boards a full week to dry; then the braces may be earefully removed and they may be transferred to the store box.

In my own experience I have found that a tonch or two of the chloroform brush on the pill-box containing small moths is suffieient to either kill or so asphyxiate them that they can easily be momnted. I have also found that strips of corn pith or even of soft cork, with grooves cut into them, are very handy for the pinning and spreading, and that by means of a small, broad-tipped, and pliable forceps the smallest specimens ean be deftly arranged in the groove and kept in place until pinned. In fact, for all persons who have not rery great experience and dexterity this method is perhaps more to be recommended than that of holding them between the thumb and fingers. Where chloroform is used either to libll or dearden specimens, it is important that after they are once spread and in the drying box they shonld be subjected to an additional asphyxiation, as the larger species may revive and areapt to pull away from the holding strips. and thus rub off their scales.

Microlepidoptera, together with Microhymenoptera and Diptera may be eonveniently pinned on fine, short pius, and these thrust into an oblong bit of cork or pith. This form of mounting has already been described and is represented in figure 102. The neatest mounting of Microlepidoptera which I have seen is the work of ny assistant, Mr. Albert Koebele, who mounts these insects on an oblong strip of pith. This is very light and presents no diffienlty in pinning. The strips may be made of considerable length and both sexes may be pinned on the same block (see Fig. 103). MIost Lepidoptera present on the under surface an entirely different aspect fiom that on the upper sul face, and, in such eases, it is a good plan to momnt a number of sperinens obversely.

Relaxing.-It will frecuently be desirable to se-spread insects which have been incorrectly mounterl, or to spread specimens which have been collected and stored in papers, or pinned and allowed to dry without being prepared for the cabinet. Such specinens may be relaxed by placing them in a tight tin vessel half filled with moist sand to which a little carbolis aleid has been adrled to prevent molding. Small specimeus will be sufficiently relaxed to spread in twrenty four 
homrs. Larger specimens require from two to thee days. More rapid relaxing may be caused hy the use of steam. and a flat piece of cork with the specimens laid or pinned thereon and floated on the top of hot water in a closed vessel constitutes an excellent relaxing arrangenent.

Inflation of the Larve of Lepidoptera.-The larve of Lepidoptera pre. served in alcolol are excellent for anatomical and gencral study, but are not very suitable for use in economic displays. This means of freservation also has the disadrantage of not generally preserving the natmol color and appearance of the specimens. These objections may he aroided, howerer, by the dry method of preserving larve, viz. by blowing or inflation. The moress may be tescribed as follows: The larva may be operated upon alive, lont shonld preferably be first killed by dipping in chlorotorm or alcolol, or in the cyanide bottle. It is then placel on a piece of blotting paper and the alimentary canal cansed to protrude from one-eighth to one-fonth of an inch, by rolling a pencil over the larra from the head to the posterior extremity. The protruding tip is then severed with a shar linife or pair of dissecting se issors, and the contents of the abdomen are forcerl out ly passing a pencil, as before, a number of times over the larva. Great care should be exercised in expressing the fluids not to press the pencil too strongly against the lavia or to continue the mperation too long, as this will, esperially in delicate larve, remove the pigment fiom the skin, and the sperimen whrn dried will shew discolored spots and be nore or less disturted. The larva shomid bo moved trom place to place on the blottime baper during the opelation, so as not to become soiled by its own juices. A straw, or a glass tube drawn to a point at the tipe is then insertel in the protruling portion of the alimentary canal. It a straw is nised the larva may be lastened to it by thrusting a pin through the wall of the canal and the straw. In the case of the glass tuke the alimentary canal can le cansed to adhere by drying for a fow minntes and this operation may be hastened and the fastening made more serue by touching the point of union with a drop of ghe. The straw or galass tube is then attarlued to a small rubber bas, previously inflated with air, the ordinary dentist's or chemist's gas bats ansering admipahly for this purpose. The larva is now ready for drying, and for this purpose a drying oren is required into which it is thrust and manipulated by turning it from side to side, to keep it in proper shape and

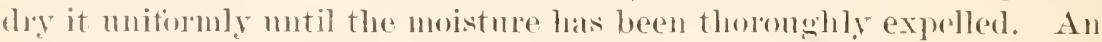

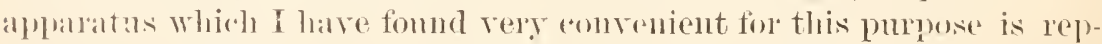

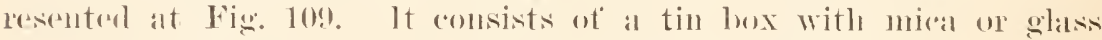
slirles.e. to allow the lanval to be eomstantly in sight. It loas also a hinged topl, b, whoh may bo krept rosed or partly open, or entirely open, as may low neressary, duringe the operation. The ruts of the

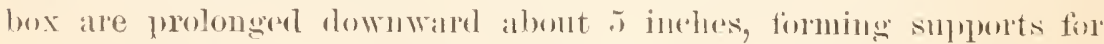

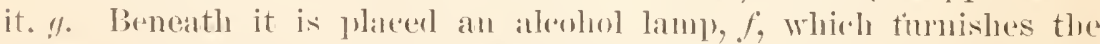
beat. In the end of the box is a circulal openine, al for the introulue. 
tion of the larva, and this may be entirely or partly closed by a sliding door, a. It will be found of advantage to line the bottom of the bos.

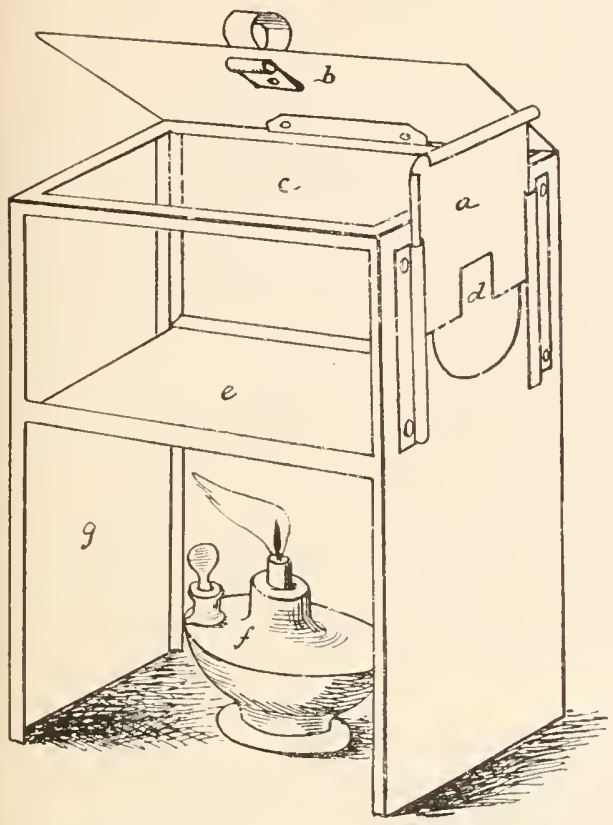

Frt. 109.-Drying oven for the inflation of larve (original).

(inside) with a brass screen of rery fine mesh to distribute and equalize the heat. This apparatus cau be very easily made by any tiusmith and will answer erery pmove.

The larve of Microlepidoptera or young larva may be dried withont expressing the body contents, and will keep, to a great extent, their normal shape and appearance. The methor ronsists in placing them on a sand bath, heated by an alcohol lanıl. The vapor generated by the heat in the larva inflates them and keeps the skin tant mutil the juices are entirely evaporated. They may then be glned at once to cardboard and pinned in the cases.

In the momting of large inflated larve I lave adopted the plan of supporting them on covered copper wire of a size varying with the size of the larva. A pin is first thrust through a square bit of cork and the wire hronght tightly abont it and wrapped once or twice, compressing the cork and giving a firm attachment to the pin. The wire is then neatly bent to form a diamons-shaped loop about one-sixth of an inch in length and again twisted loosely to the end-the length of the twisted portion abont equalling that of the larva to be momted. This is then eitlrel thrust into the blown skin of the larva throngh the anal opening, the larva being glned to the wire by the posterior extremity, or the larva is glued to the wire by the abdominal legs and venter, thus resting on the wire as on a twig. This style of momuting is ilhstrated in Pl. I. With a little experience the operator will soon be able to intlate the most delicate larvit and also the very hairy forms, as for instance Orgyia lencostigmu, withont the least injury, so that the matural color's and aprearance will be preserved.

Another very good method, and still safer, is to blow with straw, cut the straw square off at the anus, and then preserve the thoronghly dried and blown specimen in a glass tube of about the same length and diameter as the larva. This arrangement in conjunction with the tube holder, which will be described further on, is one of the most satisfactory for the preservation of intlated larve. 
For the biological-display collection, larve may be blown in varions natmal positions, to be subsequently fastened on leaf or twig or in burrows which they have occupied. Fastened to artificial foliage in which nature is imitated as much as possible, such blown laver al' quite effective.

Stuffing Insects.-Large larve may sometimes be satisfactorily pre. served for exhibition purposes by stuffing them with cotton. 'The method consists simply in making a small slit with the dissecting scissms or a short scalpel between the abdominal prolegs, and removing the borly contents. Powderen arsenic or some other preservative should be put in the body of the larva with the eotton used in stuffing it, and the slit chosed by a few stitrhes, when the larva may be dried and mounted on a twig or leaf. This methor of stuffing with cotton is also applicable in the case of rertain large-bodied insects which, if mounted and put away withont preparation, would be liable to decompose, as, for instance, the larger moths, grasshoppers, etc. A slit can be mado in the centel of the abdomen or near the anms beneath, and the body contents removed and replaced with eotton. Stuffing in this way with rotton is of especial advantage in the case of certain of the large endophytous insects which grease badly. The cut will not be noticed after the insect has dried, or it may be elosed by a stiteh or two.

Dry Preservation of Aphides and other soft-bodied Insects._Diffienlty has always been experienced in preserving soft-bodied insects, particularly Aphides, in a condition serviceable for subsequent scientific sturly. Fept in alcohol or other antiseptic fluid, they almost invariable lose much of their normal appearance, and many of the important characteristics, especially of color, are obscured or lost. The balsam mount is also mosatisfactory in many respects, as the body is always more or less distorted and little can be relied upon except the renation and the jointed appendages. A method of preserving soft-bodied insects by means of the sudden application of intense heat was eommmicated to the Entomologische Nachrichten, Tol. Iv, page 15.5, by Herr D. II. R. von Schlechtendal. It is clained for this method that the Iphides and other soft-bodied insects can be satisfactorily preserved in form and coloring, the success of the method being vouched for by a number of well-known German entomologists, Kaltenbach. Giebel, 'l'aschenberg', Mayr, and Rudow. A condensed translation of the method employed by Schlechtendal is given by .J. WT. Domglas in the Entomologfists' Monthly Magazine for Decembor', 187s, which I 'puote:

The heat is derived from the flame of a spirit or petrolemu laup, Abore this is placed a piece of sheet-tin, and wer this the roasting proceeds. I hulging lamp eylinder, latil horizontally, serves as a roasting oven. In this the inseret to be dried, whin prepared as duected, and stuck on a piece of pith, is to lue held over the llame; or the eylinder maty be (losed at the lower end with a cork, which shonld extend far in warls, and on this the insert shonld be firstened; the latter mote being proterable leanse the heat is more coneentrated, and one hamd is left free. The mode of procerlure varies aecording to the mature of the olyjeets to be treated. For the clitss of larger objects, such as Hemiptera, ('icadina, and Orthoptera, in their yomng stages of 
existence, the heat must not be slight, but a little practice shows the proper temperature required. If the lieat be insufficient, a drying up instead of a natural distention ensues. The insert to be roasted is to be pierced by a piece of silver wire on the under side of the thorax, but it is not to be inserted so far as to dimage the upper side, and the wire should then be carried through a disk of pith, placed beneath the insect, on which the legs shonld be set ont in the desired position. But with some objects, such, for instance, as a young Strachia, the drying proceeds very quckly, so that if ristention be not observed then the heat is too wreat, for the expansion of the air inside will force oft the head with a loud report; also, with softer, thicker Pentatomidie care must be taken to begin with a lueat only so strong that the interual juices do not boil, for in such ease the preparation would be spoiled. It is of advantage to remove the cylinder from time to time, and test, by means of a lens, if a contraction of the skin has taken place on auy part; if so, the roasting is to bo continued. The desired hardness may be tested with a bristle or wire.

For Aphides the living Aphis is to be put on a piece of white paper, and at the moment when it is in the desired position it is to be held over the flame, and in an instant it will be dead and will retain the attitude. Then put it, still on the paper, mto the oven; or, still better, hold it over the heated tin. carefully wateling the drying and moving the paper abont in orter to prevent it getting singed. The roastung is quickly accomplisher in either way, but somewhat slower out of the oven especially in the larger kinds, such as Lachnus. If the paper turn brown it is a sure sign that caution is requisite. To pierce these brittle preparations for preservation is hazardous, and it is a better way to mount them with gum on card, placing some examples on their baek.

For Cecidomyidie, Agromyzidx, Cynipida, and other small insects liable to shrink, yet containing but little moisture, such as Poduridie, Pediculidit, Psyllidie, etc, another method is adopted. Over the insect, monnted on a wire, etc., as above directed, a thin chemical reagent glass or glass rod, heated strongly at one end, is hell, and the heat involved is generally sufficient to bring about the immediate drying and distention, but if the heat be too little the process unst be repeated; and, although by this method the danger of bnrning is not obviated, yet the position of the legs is maintained much better than by the aforesaid roasting.

Larve of all kumds, "p to the size of that of Astynomus adilis, even when they have long been kept in spirits, may be treated successfully by the roasting method; but with these objects care must he taken that the heat is not toustrong or else the form will be distorted. For small larve it is preferable to use a sliort glass, in order better to effect their removal without touching the upper part, which becomes covered with steam, and contact with which would eause the destruction of the preparation. Larve of Coleoptera, which contain much moisture or have a mucous surface, must lie on a bed of paper or pith in order to prevent adhesion and burning, and these may be further a voided if the eylinder be slightly shaken during the process, and the position of the object be therehy changer.

Many Aphides and Coceids are covered with a waxy secretion which interferes very materially with their easy examination. Mr. Howard has overcome this difficulty by the following treatment:

"With Aphides and Coccids which are covered with an abundant waxy secretion which ean not be readily brushed away, we have adopter the plan of melting the wax. We place the insect on a bit of platinmm foil and pass it once over the flame of the alcohol lamp. The wax melts at a surprisingly low temperature and leaves the inseret perfectly clean for study. This method is particularly of nse in the removal of the waxy eocoon of the pupte of male Coceidie, and is quicker and more thorougl 
than the nse of any of the chemical wax solvents which we have tried." (Insect Lifr, I, 1. 1.i2.)

Iounting specimens for the Microscope. - The study of the minuter forms of insect life, inclucling Parasites, Thysanura, Mallophaga, the newy hatched of most insects, etc., requires the nse of the microscope, and some little knowledge of the essentials of preparing and mounting specimens is needed. The smbject of momting the different organs of inserts and the preparation for histologieal study of the soft parts of insects opens np the immense field of microscopy, the use of the innmerable momting media, the special treatment of the objects to be momiterl, stainiug, section-entting, and many other like topics, a full description of which is altogether out of place in the present work. Anyome desiring to become thoromghly versed in the subject should consult some of the larger manuals for the microscopist, of which there are many. For the practical working entomologist, lowever, a knowledge of all these methods and processes is not essential, and in my long experince I have found that momting in Canala balsam will answer for almost every purpose. The softer-borlied forms will shrink more or less in this substance, and it is frequently necessary to make studies or drawings of them when firshly momeded: or, if arditional specimens are preserval in aleohol, they will suplelement the momted specimens and the material may be worked np at the convenience of the stment. The matedials for the balsan momts may be obtained of any dealer in mieroscopical supulies. They consist of glass slites, :3 inches by 1 inch, thin cover-glassosotidifferent dimensions, and the prepared balsam. The balsam is put up very conveniently for nse in tin tubes. I sufficient quantity is pressed ont on the center of the glass slide, which has previonsly beren madre thoronghly clean and dy: the insect is removed from the alcohol, and when the exeess of lignor has been removed with bilmbers paper, it is placed in the halsam, the linbs and antemme being arranged as desired by the use of fine monnting-needles. A corereglass, also made thoroughly elean and dry, is then plared over the specimen and pressed gently mith the balsam entirely fills the space between the corer and the glass slide. The slide should then be properly labeled with a mumbrr referring to the notes on the insert, prefierably placerl on the mplex alge of the slide above the cover-glass, and also a label giving the number of the slisle and the number of the slisle box. On the opposite end of the slide may be placed the lahel giving the name of the speeimen momuted and the date. If a revolving slide table is employed to centeg the momnts, the alperaranere of the slide may be

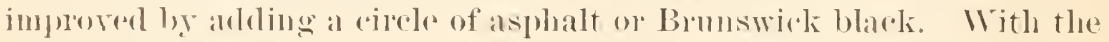
balsam momts, however, this souling is not necessally. The slide (Fig.

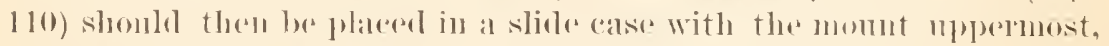
and shomle to kept in a horizontal position to porent slibling of the (o)

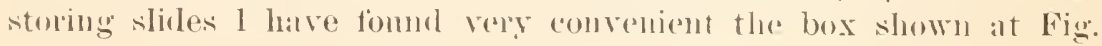


111. It is constructer of stromg pasteboard and is armanged for holding twenty-six slides. The cover beals numbers from 1 to 26 , opposite which the name of each insect momnted, or the label on the slide, may

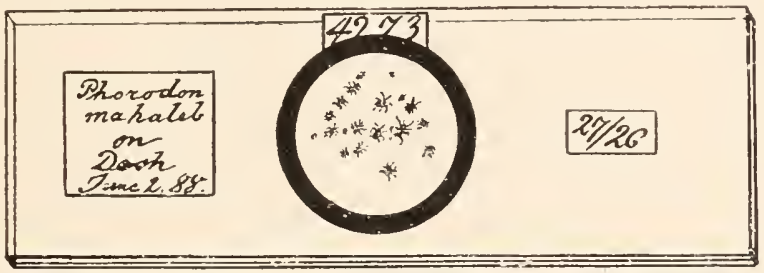

FIG. 110.-Balsam mount, showing method of labeling, ete. (original).

be written. This box when not in nse is kejt in a pasteboand rase, on which may be placed the number of the box. These slide eases may be stored in drawers or on shelves male for the purpose. In mounting specimens taken from alcohol it is advisable to put a drop of

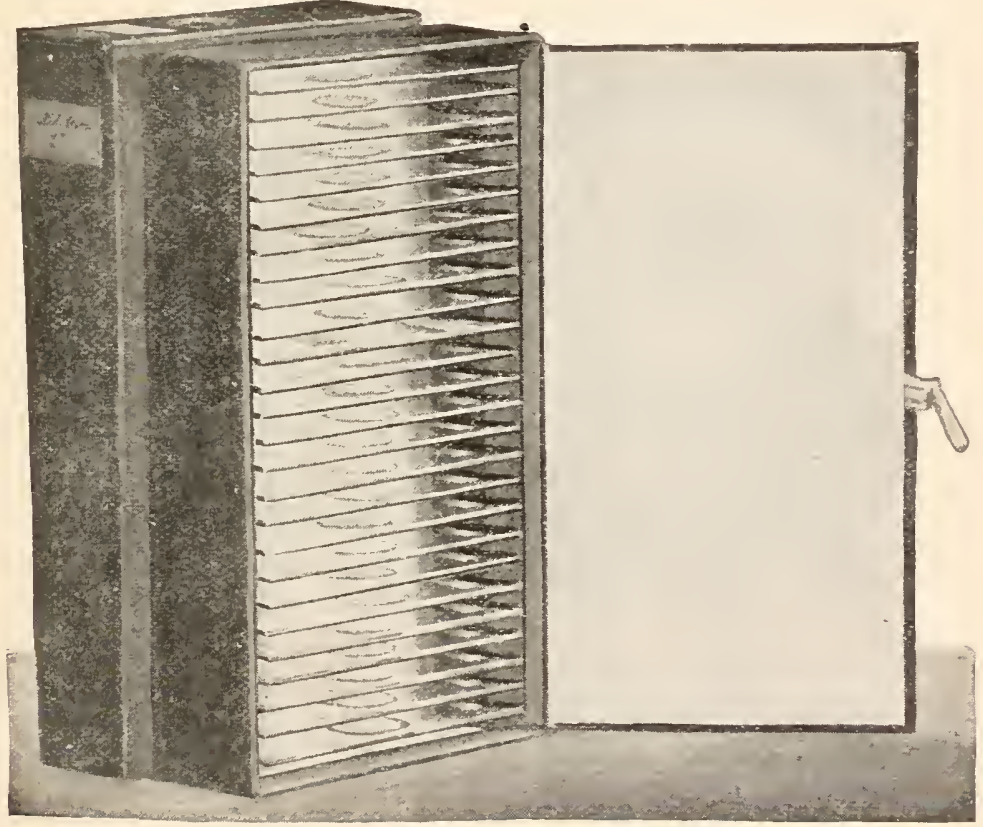

Fig. 111.-Slide case, showiug method of labeling case and of numbering and labeling slides (original).

oil of cloves upon them, which unites with the balsam and ultimately evaporates. The occurrence of minnte air bubbles under the corerglass need occasion no uneasiness, for these will disappear on the drying of the balsam.

In mounting mimute Acarids or mites it has been found best to kill the insects in hot water, which canses them to expand their legs, so that 
when momuted these appendages an readily be studied. It momted living, the legs ane almost invariably eurled nj molor tho borly and ran not be seen. This method may also be nsed in the rase of other minnte insects. Some inserts, such as minnte Diptera, are injured by the nse of hot water, and for these dipying in lot spirits is recommended.

In the monnting of Aphides the same diffindty is avoided in a moasure by Mr. G. B. Burktom, anthor of "A Momograph of' the British Aphicles." ly first plaring a few dotsof balsam on the glass slide. towhich the inseret is transferedel by means of a moistemed anel's-hair brush. The reforts of the inseret to resalpe will cause it to spreat out its leas in a natural position and a corer glass may then be placed in position and a drop of the balsam placerl at the sille, when, by eapillarity, it will fill the space between the slicle and enrel gelass and the limbs will be fommd to have remained extemded. It three or fom drops of the balsam ate put on the glass the wings may also be bought down and caught to then so that they will remain expanded in shape for examination.

Prepuring and Mounting the Wings of Lepidoptera.-The student of Lepidoptera will frepurnty find it necessary in the study of the renation of wings to bleach them or denude them of their seales in some way. Various methods of bluaching and mounting the wings of these insects lave been given, and a tix of them may be brietly outlined.

The simplest and quickest, lut perhaps the least satisfaetory, mothod is to remove the soales with a camel's-laair brush. This will answer for the larger forms and where a rery eareful examination is not requirer. For more careful examimation aul study the wings are first bleached by the action of some caustic solntion and then mounted in balsam for permanent preservation. Chambers's method for Tineina, Tortricina, Pyalidina, and the smaller moths generally, is as follows: The wine is placed on a microscopic slide in firom 3 to 4 drops of a strong solution of potash, the amount varying aecording to the size of the wing. A cover of glass is then placed in position on the wing as in ordinary mounting.

The quantity of liguid should be suffieient to fill the space beneath, but not sufficient to that the corer slass. The mount is then placed over an aleohol thane, removing it at the first sign of ebullition, when the wing will be fomm demulerl, it it be a fresh specimen. An old

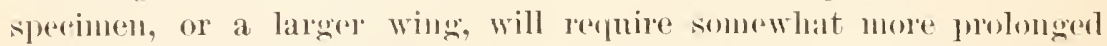
boiling. The fluid is drawn of loy tilting the glass or with bibulous paper, and the potash removerl by washiug with a few drops of water. The rover glass is then removed and the wing momeded either on the same slido in balsam or floaterl to another slide, or at onere acemately

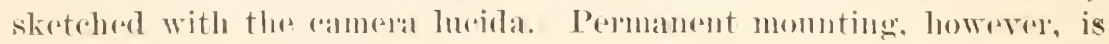
always to be reenmmomolixl.

Tlie bimmoek mothod of bleaching the wings of Lepidoptera, given in Psyche, Vol. I, ply.97-99, is as follows: He uses for bleathing a molifica- 
tion at the chlorine bleaching process commonly employed in cotton bleacheries, the material for which is sold by druggists as chlorate of lime. The wing are first soaked in pure alcohol to dissolve ont the oily matter, which will act as a lepellant to the aqueous chlorine solution. The chlorate of lime is dissolved in 10 partsof water and filtered. The wings are transferred to a small quantity of this solntion and in an hour or two are thoronghly bleached, the veius, however, retaining a light brown color. If the bleaching does not commence readily in the chlorine solntion the action may be hastened hy previonsly dipping them in dihte hydrochlorie acid. When suffieiently decolorized the wings shomld be washed in dilute lydrochloric acid to remove the deposit of calcic carbonate, which forms by the mion of the calcie hydrate solution with the arbonic dioxide of the air. The wings are then thomonghly washed in fure water and may be gummed to cards or momited on glass slides in Canada balsam, first washing them in aleohol and chloroform to remove the moistmre. If either of the solutions known as ean de labaraque and eau de javelle are used in place of the bleaching powder, no deposit is left on the wings and the washing with acid is obviated. This process does not dissolve or remove the scales, but merely renders them transparent, so that they do not interfere with the study of the venation.

Prof. C. H. Femald (American Monthly Microscopical Journal, 1, p. $172,1880)$, mounts the wings of Lepidoptera in glycerin, after having first cleared them by the Dimmoek process. After bleaching and wasling, the wings are dried by holding the slicles over an alcohol flame, and a drop of glycerin is then applied and a cover glass put on at once. By holding the slide again over the flame until ebullition takes place the glyeerin will replace the air nuler the wings and no injury to the structure of the wings will result, even if, in refractory cases, the wing is boiled for some little time. The momnt in this method must be sealed with some microscopic cement, as asphalt or Brunswick black.

A methor of monnting wings of small Lepidoptera for studying renation, which I have fonnd very convenient, is thus described by Mr. Howard in Insect Life, Tol. I, P. 151:

"Some years ago we nsed the following method for studying' the venation of the wings of small Lepidoptera. We have told it since to many friends, but believe it has not been published. It is in some respects preferable to the so-ealled 'Dimmock process' and particularly as a time-sarer. It is also in this respect preferable to denndation with a loush. The wing is removed and mounted upon a slide in Canada balsam, which should be preferably rather thick. The slide is then held over the flame of an alcohol lamp until the balsam spreads well over the wing. Just as it is abont to enter the veins, however, the slicle is placed upon ire, or, if in the winter time, ontside the winclow for a tew moments. This thickens the balsim immeliately and prevents it from entering the voins, which remain permanently filled with air and appear black with transmitted light. With a little practice one soon becomes 
expert enomgh to remove the slide and cool it at just the right time, when the scales will have been rendered nearly transparent by the balsam, while the reins remain filled with air. We have dome this satisfactorily not only with Tortricida and Tineida, but with Noetuids of the size of Aletir and Lenconia. The mounts are permanent, and we have some which have remained nuchanged since 1sson. ['rot. Riley had for some years before this been in the habit of momnting wings in balsam, in which of course the suales rleared after a time."

Prof. Tohn B. Smith recomments a modification of the Dimmork process of bleaching the wings of Lepidoptera, publishing it in Insect Life, Vol. I, 11. 291, 292 , as follows:

"By the Dimmock process the wings are first acted 11pon by a saturated solution of the chloride of lime, chlorine being, of conse, the blearhing agent. Afterward they are washed in water to which hydrochlorie acid has been added, to get rid of the slight deposit of lime. The process is a slow one for thickly scaled, dark-colored insects, and it ocenred to me to try a mixture of the ehloride and acid, liberating the chlorine gas. The method was absolutely successful, the wings deenorizing inmediately and being ready for the slide within two minntes. In fact, very delicate wings can scarcely be taken out quick enough, and need very little acid. The advantage is the rapidity of work and the certainty of retaining the wings entire, the chloride of lime sometimes destroying the membrane in part lefore the bleaching is complete. The disadvantage is the vile smell of the chlorine gas when liherated ly the combination of the two liquids. For quick work this must be endmed, and the beanty and completeness of the result are also adrantages to coniterbalance the discomfort to the senses."

For further special directions for mounting, for microscopic purposes, different inserts and the different parts of insects, representing both the exterual chytinonis covering and the internal anatomy, the student is reterred to special works.

PRESEITITION OF ALCOIOLIC SPLCIMENS.

APPARATUS AND METHODS.-The collections of most value, especially to our valrions agricultural colleges and experiment stations will be landely of a hiologic and ecomomic chaldeter, and the interest attaching to a kinowledge of tho life history of inseots will indure many collectors to huild mp independent biologic rollections. Very murelo of this biological material will be alcoholic, and thongh many innotiture states of inseres may be preserved by dry processes, still the bulk must nexds be liept in liguid. This material may, when not abmolant. he liept with the general systenatie eollection, hut experiene has shown that it

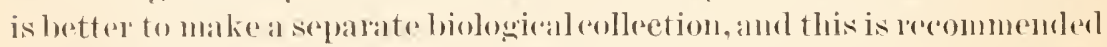
espereially for state institntions where the collections may be expected to attain some eomsidemable proportions. In the case ot sirele collecetions it is very desimble to arlopt some method of seroring the vials in such a 
manner that they can casily be transferred from one place to another and fastened in the boxes or drawers employed for pimed insects. For directions in this regard I reprodnce from an article on the subject in Insect Life, Vol. II, pl. 345, 346, which was republished, with slight changes, from my ammal report for 18st as Fomorary Curator.**

Tials, stoppers and Holders.-The vials in use to preserve such specimens as must be left in alcohol or other liquids are straight glass tubes of varying diameters and lengths, with round bottom and smonth even month. The stoppers in use are of rubber, which, when tightly put into the vial, the air being nearly all expelled, keep the contents of the vial intact and safe for years.

Various forms of bottles are used in musenms for the preservation of minute alcoholic material. I have tried the flattened and the square and have studied varions other forms of these vials; but I am satistied that those just described, which are in use by Dr. Hagen in the Cambridge Musenm, are, all things considered, the most convenient and reonomical. A more diffienlt problem to solve was a convenient and satisfactory method of holding these vials and of fastening them into dranwers or cases held at all angles, from perpendirular to horizontal. Most alcoholic collections are simply lept standing, either in tubes with broad bases or in tubes held in wooden or other receptacles: but for a biologic collection of inserts something that conll be nsed in comnection with the pinned specimens and that conld be easily removed, as above set forth, was desirable. After trying many different contrivances I finally prepared a block, with Mr. Hawley's assistance, which auswers every purpose of simplicity, neatness, secmrity, and comvenience. It is, so far as I know, mnique, and will be of alvantage for the same lmlpose to other museums. It has been in use now fol the past six years, and has been of great help and satisfaction in the arrangement and preservation of the alcoholic specimens, surpassing all other methods for ease of handling and classifying.

The blocks are oblong, one-fourth of an inch thick, the ends ( $c$ e, Fig. 112) beveled, the sides either beveled or straight, the latter prefriable. They vary in length and breadth according to the different sizes of the rials, and are painted white. Upon the upper side of these blocks are fastened two enrved clamps of music wire $(b \quad b)$, forming about twothirds of a complete circle. The fastening to the bloek is simplo and secure. A bit of the wire of proper length is first donbled and then by a special contrivance the two ends are bent aromud a mandrel so as to form an insertion point or loop. A brad awl is nserl to make a slot in the block, into which this loop is forced (e, Fig. 11:, 5), a klop of warm water being first put into the slot to soften the wood, which swells and closes so firmly around the wire that considerable fore is required to pull it out. Four pointed wire nails $(d, d d)$, set into the bottom so as

* Annual Report of the Sinithsonian Institution for 1886, Part II, Report of the National Museum, Ip. 182-186. Washington, 1890. 
to pujert about one-fomtl inch, serve to hold the hlork to the cook hottom of the ease or drawer in which it is to be plared. The method of use is simple and 7earlily seen from the accompanying figures, which lepresent the block firm all sirles.

The adrantages of this system ale the ease ame security with which the block ean be placed in or removed from a box: the wase with which a vial ean be slipped into or remored form the wire clamps; the security with which it is held, and the fact that juatieally no part of the contents of the vial is olscemed by the holder-the whole being visible from above.

The bereled ends of the block may be used for labeling, or pieces of ("loan card-hoard ('nt so as to projert somewhat on all sides may be used for this purpose, and will bo held seeure by the pius between the block and the eork of the drawers.

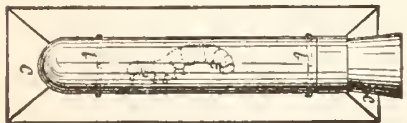

1

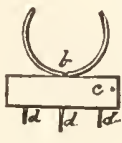

3

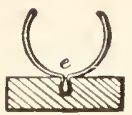

5

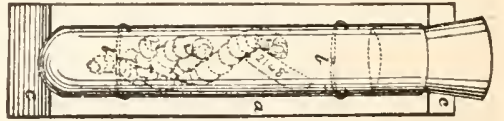

$\boldsymbol{2}$
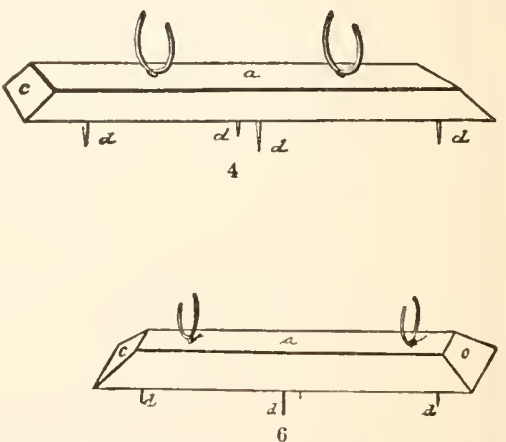

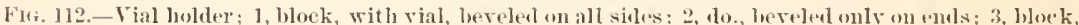

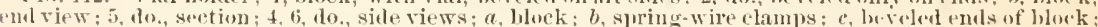
$d$, pointed wirenals; $c$, point of insertion of clamp. (Lettering on all figures corresponsls.)

The nse of rubber stoppers in this eomutry was first instituterl by Dp. I. A. Hagen in commetion with the Cambridge biological collection,

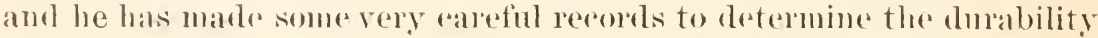
of such stoppers. From an examination of some seven thomsand rials with rublex stoppers, two-thiphs of which had beren in use for forn ten to twelloe years, he comes to the collelusion that less thath one in a

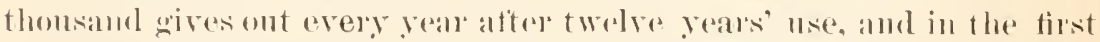

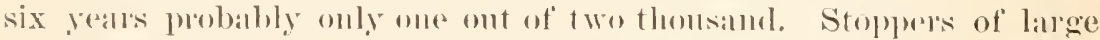

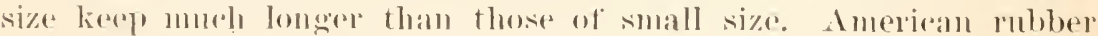

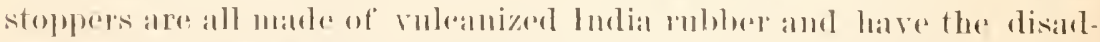

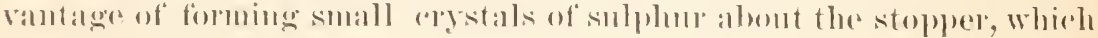

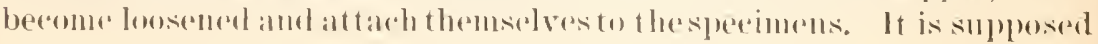


that pure rubber-stoppers used for chemieal purposes would uot pre sent this disalvantage, which may be obviated, how'ver, or very much rednced, if the stoplpers are washed or soaked, preferably in hot water, for an hour or two at least.

If stopler's are stored for a comsiderable time and exposed to the ar they become rery hard and unfit for use, and Dr. Hagen has drawn attention to a method recommended hy Professsor W. Hemple, of Dres. den, saxony, of preventing them from becoming thus handened. He says that to keep rubber stoppers or rubber apparatus of any sort elastic, they should be stored in large glass jars in which an open ressel containing petrolemm is placed. This treatment prevents the evaporation of the fluids which are fixed in the rubber in the process of vulcanization. It is better also to krep the light from the jar. To soften stoppers which have already become hardened, they shomld be brought together in a jar with sulphuret of carbon nntil they are pliable and afterwarl kept as recommented above.

In the use of the rubber stopper the novice may find some difficulty in inserting it in a vial filled with alcohol. The compression of the alcohol, or alcohol and air when the vial is not completely filled, forces the stopper ont, and this is true whether of rubber or cork. If a fine insect pin is placed beside the cork when this is thrust into the bottle, the air or liquid displaced by the cork will eseape along the pin and the latter may then be removed and the cork remains securely in position.

If cork stoppers have been used the rials may be stored in large quantities together in jars filled with alcohol. This will prevent evaporation of the alcohol fiom the vials, and the specimens may be preserved indefinitely. This is only desirable in the storage of duplicate specinens and nuarranged material and is not recommended as a substitute for the use of the rubber stopper. With cork stoppers evaporation can be in a measmre prevented if the cork is first anointer with the petroleum preparation known as vaseline. This substance is practically unaffecter at orlinary temperature and is sparingly soluble in cold alcohol. Experinents with it have shown that at ordinary spring aut smmmer temperatures there is no appreciable loss of alcohol firom rials and jars.

My old method of keeping alcoholic speeimens, which I abandoned for the method outlined above, was fairly serviceable, inexpensive, and warrants description.

I had special folding boxes constructed resembling in exterior alpearance a large insert box. The bottom of the box was solid and was marle by gluing together two $1 \frac{1}{2}$-inch planks.

Holes extencling nearly through the lower plank and of varions sizes to accommodate vials of different diameters were bored as closely together as the rood justified without splitting or brealking.

Tho holes were numbered consecutively and the vials when placel in them were numbered to correspond; the box also had its number, and 
in the notes the vial was loferred to by number of box aurl vial thus, $\frac{3}{3}$ (box 3, vial 73). The vial shomld projert one-halt to 1 inch above the hole, and shomld lo lowe emongh to provirle for the swalling at the wood in moist wather.

To protert the vials a cover having a deptlo of about $1 \frac{1}{2}$ inch was hinged to the back and secured in front by hook-and-eye fastenings.

This method of storing vials is satisfactory enomen for private collec:tions, but for langer public collertions is not so suitable.

A rather convenient and inexpensive method of storing vials is that user by Dr. Marx. In this method the vials are stored in a roulen

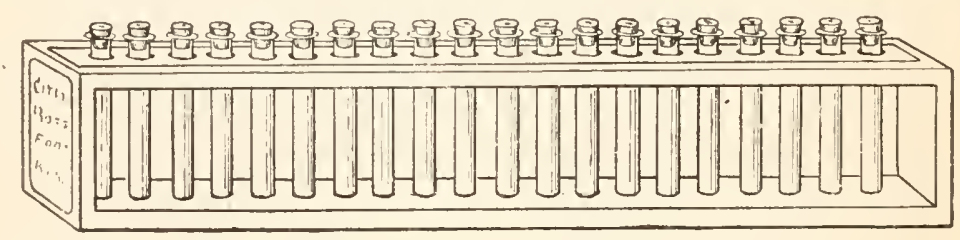

FIG. 113.-The Marx tray for aleoholic specimens (original.)

frame. shown at Fig. 113. The top piece of the tray iuto which the vials are thrust has a cork "enter, in which holes conesponding to the size of the vials are made with a gun-wad punelı. The onter end of the tray bears a label or labels describing the material in the tray. The vials used by Dr. Marx are of thimer glass than those which I recom. mond and Hare slightly at the top, as shown in the areompanying illustrations. They are made in varions sizes to acommodate larger

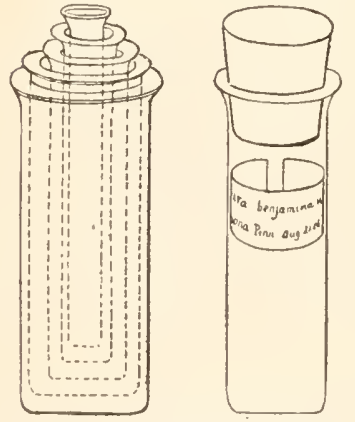

FIG. 114. - Vials used in the Mlars tray (original.) and smaller specimens. I vial thrust into the hole punched in the cork rests on the bottom piece of the tray, the flange or neck preventing it from sliding thromgh. These trays are arranged on shallow shelves in a ease or cabinet, especially romistructed for the purpose and a large quantity of material may be stored by their use in small compass. The nse of the rork center piece in the upper part of the tray is not a neressity. and a worden piece may lo msed in whirh holes are homed with a litt of proper size.

Preserving Mico-lurere in Alonhol.- The

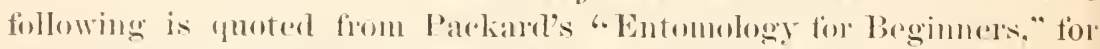

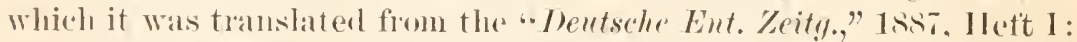

"I)r. H. Dewit\% momets the lanva and pupar of Micholepirlopterat, and also the early stages of other sulall inserets, in the following way:

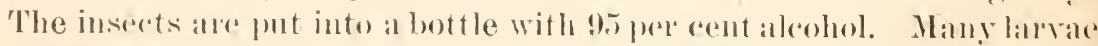
tum black in alcolosl, but boiling them in alcolon in a trot tube will bleareh them. They may then he fonally placed in whos tubes as small and thin as possible, vaying from $0.001: 3$ to 10.0106 meter in dianteter, 
accurding to the size of the insects. About 0.07 meter's length of a tube is melted over a spirit lamp, and the tube filled three-quarters full with 95 per cent alcolol, the insects placerl within and the contents of the tube heated at the end still open, and then closed by being pulled ont with another piece of glass tubing. After the glass has been held a few minntes in the hand until it is slightly cooled off, the end elosed last is once more held over the lanp so that the points may be melted together', and this end of the glass may be finished. During the whole time from the closure of the tulee nutil the romplete cooling of the glass it should be held obliquely in the hand, so that the alcolol may not wet the upper end. for if the tuhe is too full it is diffirult

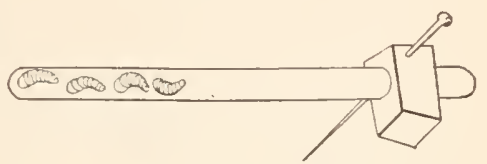

FIG. 115.-Nethod of preserving minute larve etc. (Ifter Dewitz.)

to melt it, as the steam quickly expanding breaks throngh the softened mass of glass. The tube may be mounted by boring a hole thromgla a cork stopler of the same diameter as the glass. The stopper is cut into the shape of a cube, a strong inseet pin put throngh it, and the glass tube inserted into the hole. It can then be pimed in the insect box or drawer, near the imago, so that the free end of the glass mar tonch the botton, while the other end stands up somewhat; while to keep the tube in place the free end resting on the bottom may be fastenerl with two strong insect pins. The specimens thus put up can easily be examined with a lens, and if they need to be taken ont for closer examination the tube can be opened and closed again after a little practice."

Preservative Flums.-The principal liquids in which soft-bodied insects may be suecessfully preserved are the following:

Alcohol.-As indieated in the foregoing portions of this work, alcohol is the standard preservative nsed for soft-bodied sperinens, and may be used either finll strength or diluted with water. Dihnted alcohol should always be first used with larvie, since the pure aleohol shrivels them up. The weak spirits cam afterwards be replaced by strong, for permanent preservation.

Alcohol and White Arsenic.-The method of preserving inserts recommended by Laboulbène and quoted in Packard's Entomology for Beginners, consists in plunging the insects in the fresh state into a presserative licpuid, consisting of alcohol with an excess of the common white arsenic of comneree. The larva placed in this mixtme absorbs .003 of its own weight, and when removed and pinned is safe from the attacks of museum pests. This liquid is said not to change the colors, blue, green or red of beetles, if they are not immersed for more than twentyfour hours. This treatment is applicable to the orders Coleoptera, Hemiptera, and Orthoptera. If the insect is allowed to stay in this mixture for a considerable time, say thee or four weeks, and then removed and dried, it becomes very hard and brittle and can not be used for dissection or study, but makes a good cabinet specimen. 
The white deposit of arsenic which will appeal on drying an lo washed off with aleohol.

Aleohol and Corrosice sinblimute. The same anthor resomments

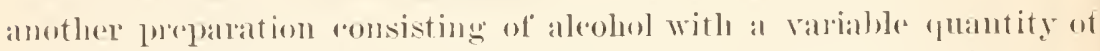

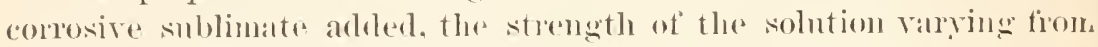
100 parts of aleobol to 1 part of entrosive sublimate for the strongest, to one-tenth of 1 part of sublimate in lo0 pants of aleohol for the wralkest. The inserets are allowed to lemain in this mixtme not longer than two hours before drying. The lantedescribed prepalation is solid to

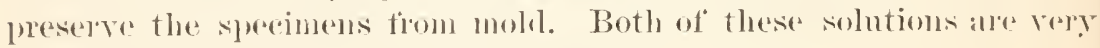
poisonoms and shombl be used with rame.

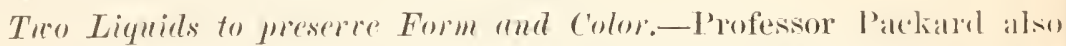
puotes the formula of $\mathrm{A}$. E. Terrill for preserving insects in their matural color and form. 'Two tormulas alle given; the first romsists of "21 poumls of common salt and 4 onnees of nited disiolved in a gallon of water and filtered. The sperimens shonld be prepared for permanent preservation in this solution by being previously immersed in a solution consisting of a fuart of the first solution amf 2 omnces of arsenite of potash in a gallon of water. Professor l'ackarr gives also the formula of $\mathrm{M}$. H. Trois for preserving aterpillars, for which it is clanimed that the colors of the caterpillars are preserved perfectly, even when exposed to strong light. The formula for this solution is as follows:

Common salt . . . . . . . . . . . . . . . . . . . . . . . . . . . . . . . . .

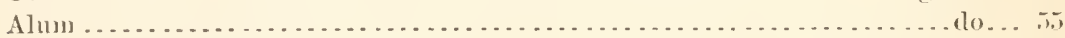

Corrosive sublimate......................................... centigrams. is

Boiling water................................................. it

Allow the liquid to cool and adr jo grains of carbolic acid, and tilter after standing five or six dalys.

Glycerin.-Glycelin, eitlee pure of mixed with water or alcoliol, is frepuently used to prescrve the larvae of delicate insects. It prescreses the color and form better than alcolool, but particularly in the case of lalva, it causes a softening of the tissues which renders thrm unfit for study.

The Wickersheim Preserving Fluid.-This valnable preserving Huir las been known for some time, lut is not very eommonly nsinl, on accomb of frequent disappointment due to the diflienlty attondung its preparation. It is colimed tom it that animal or regotable burlies

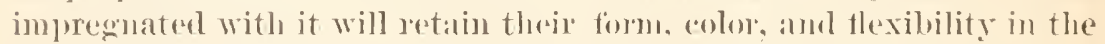
most perlect manner. The objects to be poserverl are put in the thuis for fin six to twelve days, acoording to their sim, and then taken ont and died in the air. The ligaments gemain soft and movalble, ambl the animals or plants remain tit for anatomiral clissoretion and stmely for

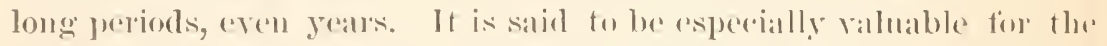
preservation of larvar and solt-bodion inserets. In older to perfectly

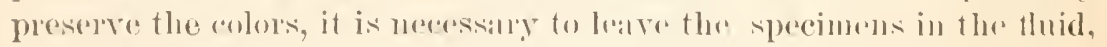
or, if they are talien out, they shomld besested vessels. 'The formula for the huid is as follows: 
Dissolve 100 gians alum, 205 grams common salt, 12 grams saltpeter, (6) glams potash, 10 grams arsenions ardi in 3,000 grams boiling water. Filter the solution, and when cold add 10 liters of the liquid to 4 liters of glycerin and 1 liter of methyl alcohol.

\section{LABELING SPECINENS.}

General Divections.-It matters little low much care and pains have been taken in the preparation and monnting of specimens, they will have little value unless aceompanied by poper labels giving information as to locality and date of collection, name of collector, and a label or number referring to notebooks, if any biological or other farcts roncerning them have been ascertained. There should be pinned to the specimen labels referring to, or giving all the information obtainable or of interest concerning it. A somewhat different style of label will be found necessary in the case of the two forms of rollertions described in the foregoing pages, namely, the biologiral or aconomic collection, and the systematic collection. For the former, nmmbers may be attached to the sperimens which will refer to the notes relating to the specimen or species. For the latter, in most cases, all necessily intormation may be recorded and made arailable by written or printed labels attached directly to the specimens. In most cases, lowerer, I find a combination of these two systems convenient and desirable. The numbering system is very simple, and is the one which I have followed in all the species for which I have biological or other notes. It consist in giving each species, as it eomes under observation, a serial number which refers to a record in a notebook. With this number may be combined, if convenient, the date of rearing or collection of the sperimen, and also the loeality and food-plant if known. The vast number of species represented in a systematic collection renders the numbering system entirely out of place and inadequate, and the laboling system alone is generally available. If it becomes necessary in the systematic collection to refer to food-plants or life-history or any other fact of interest, the numbering system should be nsed, and I recommend that the numbers be written in red ink on the labels, to distinguish at a glance the numbers referring to biological notes from other numbers that will ocenr in the collection.

Labels for pimmed specimens.-The following labèls shonld be employed in the collection: (1) Locality label, which should be as explicit as possible. (2) Date of capture. which is very useful and sometimes qute important in various ways. It indicates at what time additional specimens of some rare speeies may be secured, and greatly assists in elaborating the life history of the species, and in other cases assists in the correct determination of closely allied insects, which differ chiefly in luabit or date of appearance. (3) A label to indicate the sex. This label has recently acquired greater importance than formerly, on alcconnt of the value of the sexual differences in the distinction of 
speries. The well-known signs for male, female, amb worliel, printed

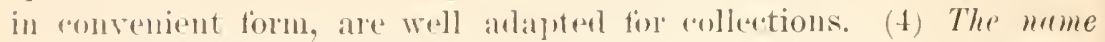
of the collertor. This label is of less value, but sometimes becomes important in detrmining the history of the speromen of the exact place of "apture. The mame of the speedes is not necessarily attared to all the specmests in a collertion, and ordinarily will be placed with the first specinen in a series in the cabinet. This and other labeling of inserts in abinnt is disenssed in another plater. Other labels are useful to indirate type specimess, namely, those of which deseriptions have been drawn np and puhlished, and which should be designated by a sperial labed written by the amthor himselt. Determinations by an anthority in a special gromp should be indicaterl. and the labels placed on speeinems hy such an anthority should not be removed.

It will not be found necessary to use a separate label for each of the data indieated above, and a single label may be marle to combine many of them, as, except for the specific mames of the insects themselves (which should always he on the lowermost label), most other words will bear abbreviation, esperally localities and dates. "A combination label. which has given general satisfaction to all to whom it has been communieated, is a two-line label printed in diamond type, on heary writing pajer. The upper line consists of the name of the locality, f.g., Wash- $^{-}$ ngtu" (a name consisting of more than eight letters to be abbreviated), and the lower line has at the right-hand wrner - DC" (interpunctuation anil spacing to be avoided as as to save suacre. This leaves on the second line sufficient room for inserting the date, which can be quickly and neatly written with ink it the labels are printed in colmums of ten or nore repetitions. The label thus combines locality with date of capturr. (or the upper line reals 'Arizona' and the lower line 'Morrison,' the label thus combining locality with the name of the collector." *

In gencral I indorse the system of labeling suggested in the above romblensation from Mr. Selnwarz, hut there is $n 0$ partieular disadvantage, ancl in fact many advantages, in special cases, in a larger label or in folderl labuls. Particularly in visiting large foreign eollections I lave fonnd it convenient to use large labels of thin paper which will contain a good deal of information "losely written m penteil and bear tolding sev elal fimes, so as not to orempy more than the ordinary label spate when pinned to the sperimens. This involves detaching the label when the

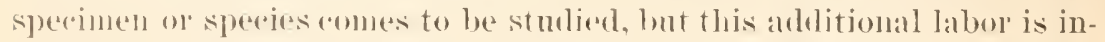
signifirant fomplated with the large anomit of valuable information

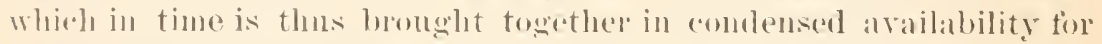

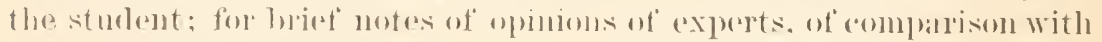

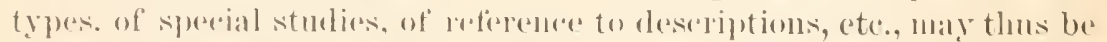
all bought together. Where there is not rom to indiate the antlority

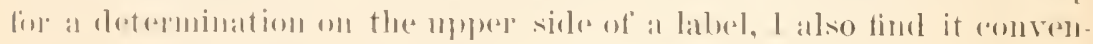
ient to elos so on the lowe siele.

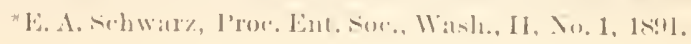


Labeling alcoholic specimens.-Aleoholic specinems, inchuding alvoholie biologie material and collections of Arachnicla and Myriofoctar, are well aldated to the labeling system, as the vials are always of suffecient size to allow the insertion of one or more labels large enom wh to contain a pretty full record of the specimen. The label may eonsist of a number referring to notes, or of a mimber together with the ofher data indicated for the systematic collection. The label in my expolionce is preferably written in pencil, which, in alcohol, is practically pormanent. Waterproof inks are sometimes nsed, and of these the oak-gall ink is molombterlly the best. Dr. George Marx, in baleding his Ararhnida, uses onion-skin paper and waterumouf ink. surh as Ilig-

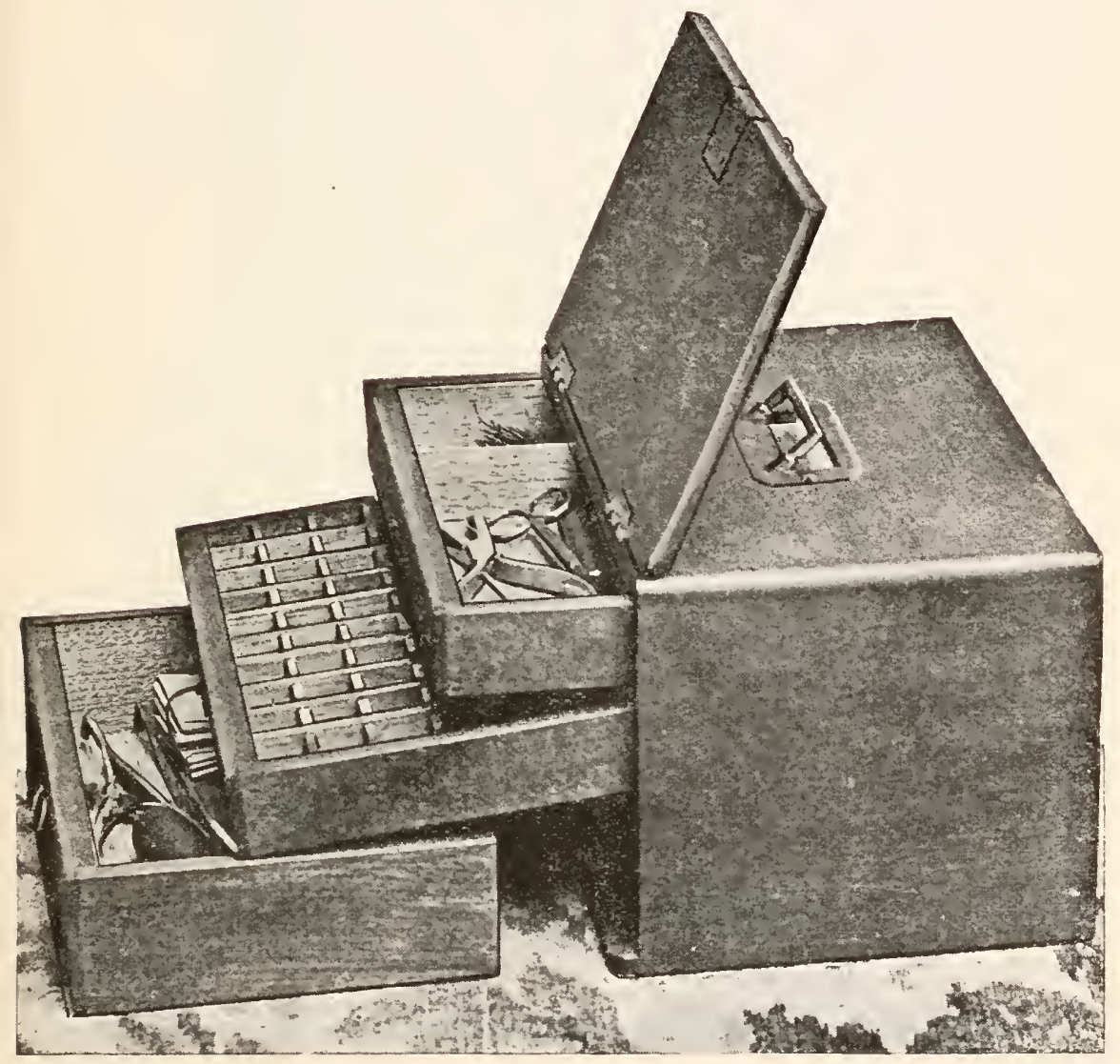

Frg. 116.-Cabinet for apparatus used in mounting and labeling. (Original).

gins's drawing ink. 'There is some danger, in placing' a label in a vial, of its settling against the sperimen and injuring it. This, however, ean generally be avoided if a little care is used. The label may be long and narrow and folded lengthwise so as to ocenpy one sicle only of the vial, or short and inserted in such mammer that it will pass aromel the inside 
of the vial, where it will be helel be the natural andesion to the galas

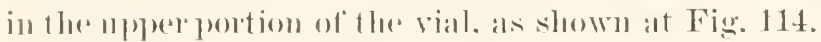

cabinet for apporatus.- The work of preparation of inserets for the

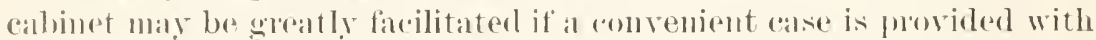

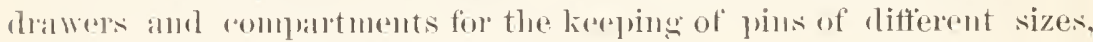
labols, braces. implements. tweezers, dissectime aplatatus, and the

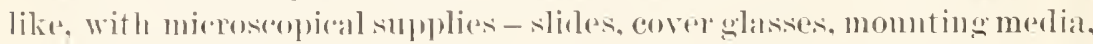

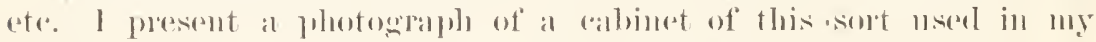

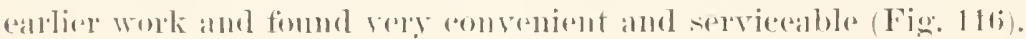

\section{IXSECT IOUKES ANI) CABINETS.}

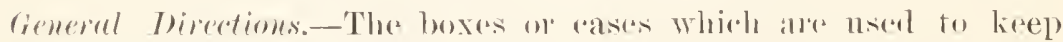
insects in permanently may los made of any dimonsioms to suit the taney, 12 by 16 inches insigle bring a ronvenient size and allowing exonomir use of eork. Thley most. hewever. be perfecetly tight and should not be more than 21 inches dere on the inside. The hottoms shombl be lined with something which will hold the pins, and the whole inside aovered with white palere, which, it delicately crosis ruled, will facilitate the regular pinning of specimens. While the size and style of the box and ribinet may be left to individual taste, some choice must be labd of material. Red cedur should never be used. I lave learned, to my sorvow, the handeful efterts of this woul, notwithstaneling it is reconmended-evidently hy those who are sult dess of having used it-as having the alvantage wro other wood of kecping off musuem pests. It seems mupossible to get this wool so seasoned but that a certain amomnt of resin will contimally exmld fom it: amd insects in boxes of this material arevery apt to soften and become gleasy. Papel boxes ale also bad, as they attract moistme and atuse the specimens to mold. Well-seasomed pine and whitewool are the most satisfactory: and, in surh boxes as have glass covers and are intended to form part

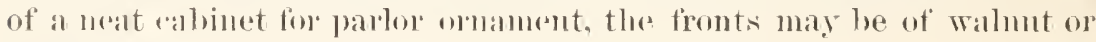
(chelery.

The rbaracter of the boxes and aboinets used for storing inserts will depend largety on the natmeand axtent of the collection and the object of the resleretor. For temporaly nse, mothing is more convernient and

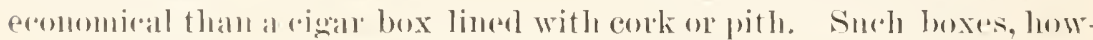
ever, shomld he rmpleyed emly for the temporary stomage of fresh spece

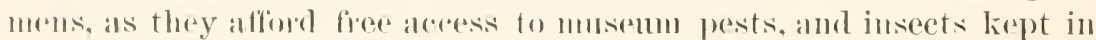

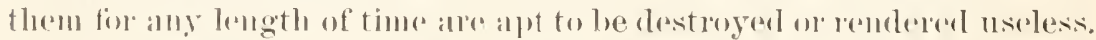

The Foldimg-bo,r.-The nse of lolding-hoxes for the working colloetor

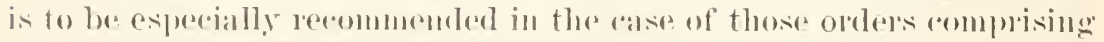

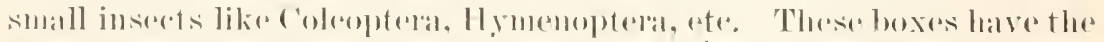

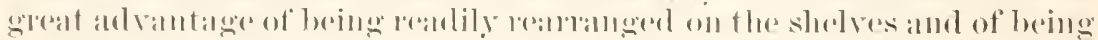

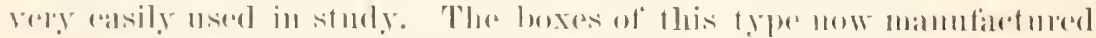

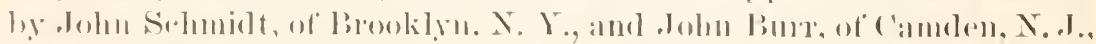

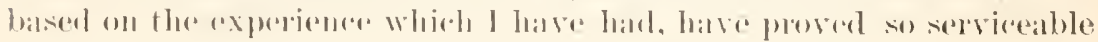


and satisfactory in this respect that I have employed them for the bulli of the collection in the National Musetun. These boxes (Fig. 117) are constructed as follows:

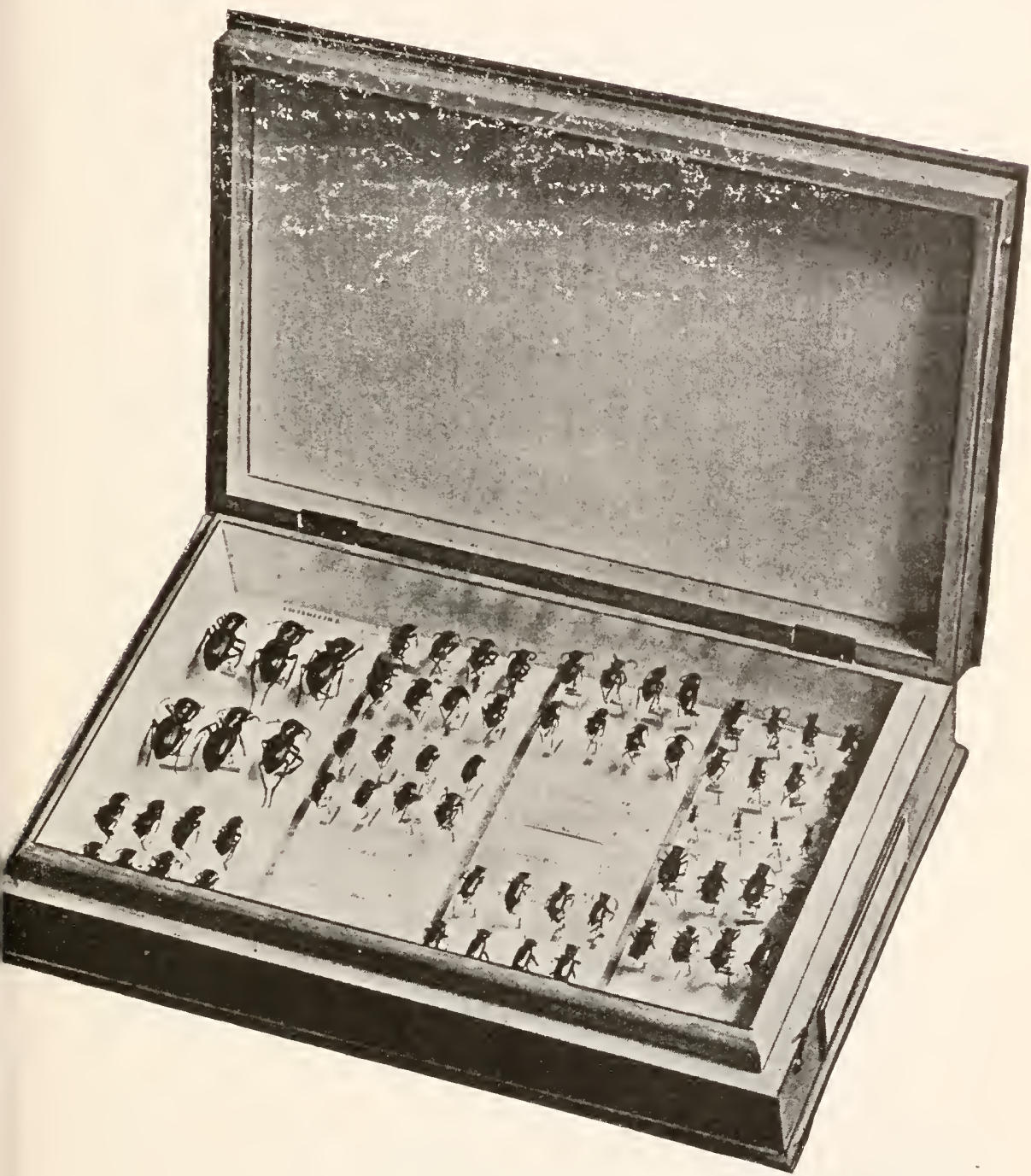

Fig. 117.-The Schmidt folding insect box, opened and showing arrangement of insects (original).

They are of white pine, shellacked and varnished, the bottom and top double and crossgrained, to prevent warping, and projecting slightly at all sides except the hinged back. They are 13 by $\$ \frac{1}{4}$ inches outside measurement. The inside measurement is $11_{4}^{3}$ by 7 . The sides, back, and front are five-sixteenths of an inch thick, with a machine joint, which is neat and very secure. The boxes are $2 \frac{5}{8}$ inches in outside depth, unequally divided, the lower portion $1 \frac{1}{2}$ inches outside depth, lined inside with a thin whitewood strip, projecting three fourths of an 
inch above the rim of the ontside box. Over this projecting lining the lid eloses as tightly as practieable and is kept from springing by hooks and eyes. The bottom is oork-lined and covored with a fine, white, glazed pajer.

Similar folding boxes with hoth sides of equal depth and both lined withcolk, when properly rovered. may be made to look like books and he set on end in an ordinary bookease. but the single lining is preferable, as there is less danger of the breakage of specimens and the boxes may either be laid flat one on the other on shelves, or, what is more convenient, placed side by side resting on the fiont edge, so that the label is attaehed to one of the narrow ends. The rows of insects are then pinued crosswise, not lengthwise, of the box, with the abdomens turned toward the front which rests on the shelf.

Ill the boxes are furnished with neat brass label-holders, in which a card containing a list of the eontents can roadily be placed and remover at pleasure. The ehief demerit of this box which I have endeavored to overeome by the above details is the tendency to warp and crack in the trying steam hoat of on Govermment buildings.

The Cubinet.-For larger insects, such as Lepidoptera, Nenroptera, ete., a larger box is desirable, and for these orders I have arlopted for use in the National Inseum a cabinet which resulted from a carceful study in person of the different forms and patterns used for entomological eollections both in this country and Europe, whether by privato in-
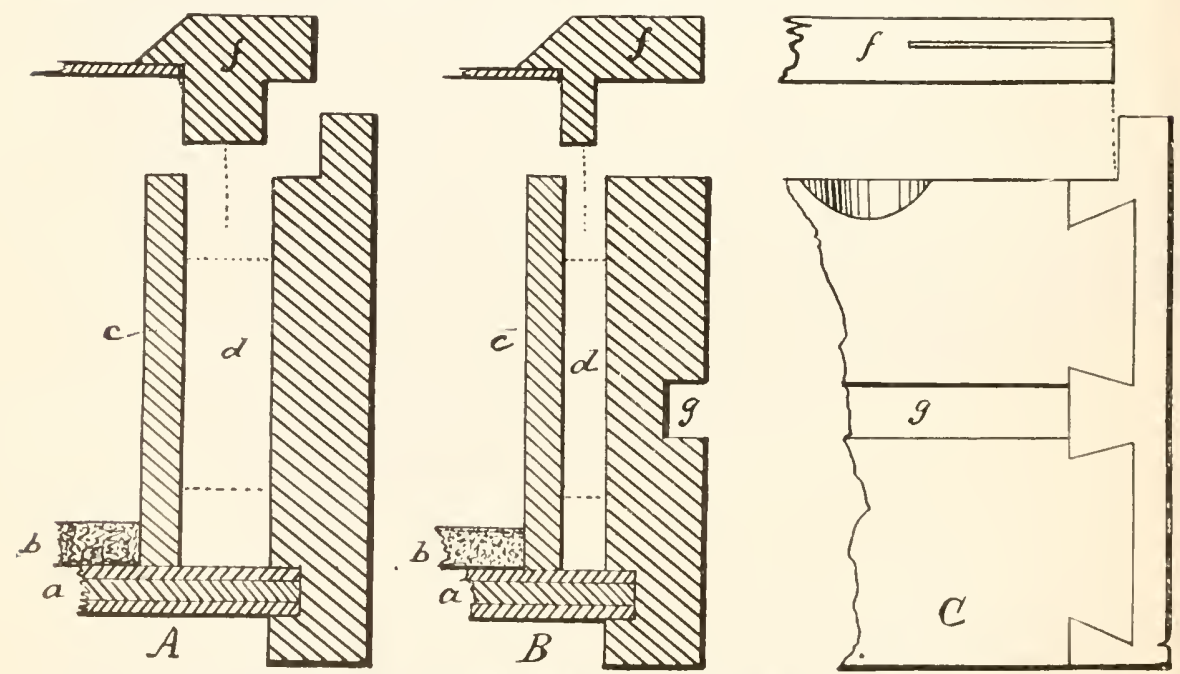

Fla. 118. - Construction of insect rabinet drawer of the National M usemun. 1, eress-section f front; B, sinnc $f$ sirle; $\mathrm{C}$, siew of front end of side, 号 natural size (original).

dividuals ol public institutions. 'The drawe and cabinet are essentially after the pattern of those used in tho Brifish (Nonth Kensington) Mnsenu, but adapted in size to ond own requirements. In the use of the National Musenu these cabinets have proved eminently woll arlapted to their object. 
The trawers (Fig. 118, A, B, C) are square, with an outside measurement of 18 inches and an outsirle depth of 3 inches. The sides and back have a thickness of three-eighths of an inch, while the front is five-eighths of an inch thick. The pieces are firmly dovetailed together. the front being clean and the dovetailing blind. The bottom, $a$, is of three ply crossgrained reneer, mu into a groove at the sides, learing a cleal inside depth of $2 \frac{1}{16}$ inches to the frame of the cover. The bottons are lined in all but forty of the drawers with first quality colli, $b$. one-fourtl of an ineh thick. At a distance of one-fourth of an inch from the sides am back and three-eighths of an inch from the front there is an inside box of one-eighth inch whitewood, e, closely fitted. and held in place by blocks between it and the onter box. There is thus between the inner and onter box a clear space, $d$, all romm, in which insecticides or disinfectants ean be placed to keep out Mnsenm pest., making it impossible for such to get into the imner box containing the specimens withont first passing through this poison thamber. The entire inside is lined with white paper, or, in the case of the uncorked boxes, painted with zinc white. The front is furnished with a plain knob. The cover is of glass, set into a trane, $f$, three-fourths of an inch wide, three-eighths of an inch thick, with a one-fourth inch tongue fitting closely into the space between the inner lining and onter box, which here serves as a groove. This arrangement furnishes a perfectly tight drawer of convenient size and not unwieldy for handling whell studying the colleetion.

The material of which these drawers are marle is California red wood, except the cover frame. which is mahogany. The cabinets containing theve drawers are 36 inches high, 40 inches wide. 21 inches deep (all outside measurements). and are closerl by two paneled doors. Each cabinet contains twenty drawers in two rows of ten each, and the druwer's slide by meaus of a groove, \% on either side, on hard-wood tongues, and are desigmed to be interehangeable.

The Lintner display Box.-For beanty and security and the perfect display of the larger Lepinlopteru, I have seen nothing superior to a box nsed by Mr. J. A. Lintner, of Albany, N. Y. It is a frame made in the form of a folio volume, with glass set in for sides and bound in an ordinary book cover. The insects are-pinned onto pieces of cork fastened to the inside of one of the glass plates and the boxes may be stool on ends, in library shape, like ordinary books. For the benefit of those who wish to make small collections of showy insects, I give Mr. Lintner's method, of which he has been kind anough to fiurn'sh me the following description:

Figs. A, B, and C represent, in section, the framework of the volume, a showing the ends, $b$ the front, and $c$ the back. The material can he prepared in long strips of some soft rood by a calinet-maker (if the collector has the necessary skill and leisure for framing it) at a cost of 60 cents a frame, if a number sufficient for a dozen boxes be ordered. Or, if it be preferrerl to order them made, the rost should not exceed 80 cents ear.h. 
brefore being plared in thr hamb of the himeler the mitering shond be earefully examimer and any defect in litting remedied, so that the grass, when placed in position, may have acenrate bearings on all the sildes. The interior of the frame is covered with tin foil. mallo as smooth as possible lefore application, fo be applied with thoroughly hoilul flour pastr. (in whiols a suall propurtion of arsenie may be unixedl) and rublued smootlly lown till the lemoval of the lolisters, whieh are apt to appear. The tin foil can be purchased, low weight, at druggists, and the sheets matied ofi and rut ly a rule in strips of proper width, allowing for a trifle ut wrerlapping on the sirles. Its rost per volumo is mejely nominal.

First-ifuality single-thick glass for sides must he sulereter, wholly free from rust, veins, air-luhbles, or any hlemish. Sneh glass ean he purehased at 15 cents a pame. The lower glass, after thoromgh reaning, wporeinly of its inner surface, with an alkaline wash, and a final polishing with slightly wottal white printing pajer, is to be firmly seenred in jts plaen by a proper number of tiu puints; the mpper glass is Imt temporarily fastmed. The binder must be direvted to eover the exposed sides of the frune with "romber" paper, bringing it over the lorker of the permaneut lowrer glass and beniath the removable mppor glass.

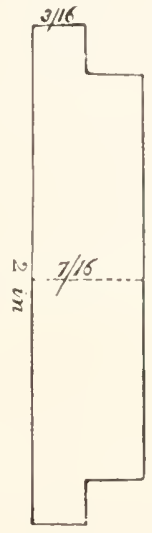

1

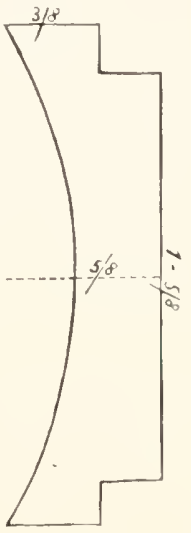

I)

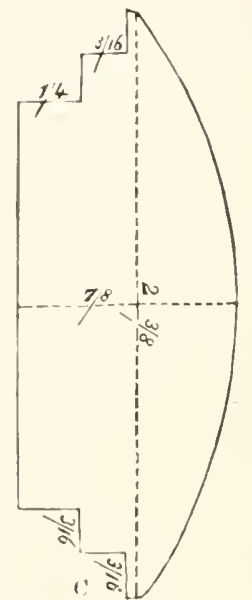

Fig. 119.-Construction of the Lintuer lox.

The covers of the volume are of heavy hinders' hoarl (No, 18), neatly lined within with glazed white paper. On me of the issirles of the lids may he attaeherl. ly jts cormers, a sluet with the mumbers amd names of the speries contaned in the volume,

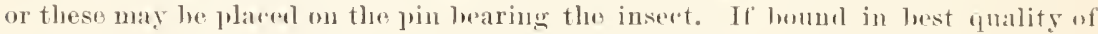

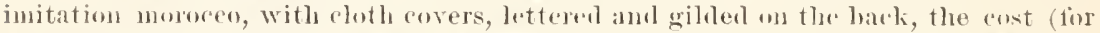

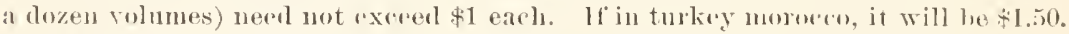

The lettering and ormancutation of the back will vary with the taste of the imdi-

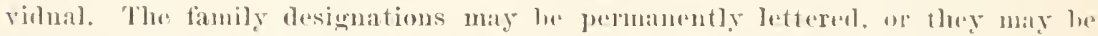
jasted ou the back, on a slip of paprer or gum laluel, as are the gremerie nimus, thus

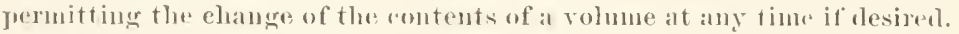

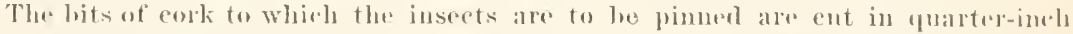

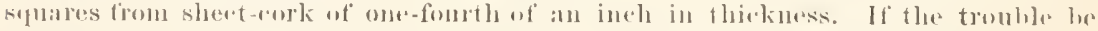

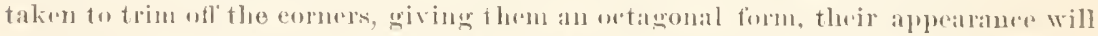

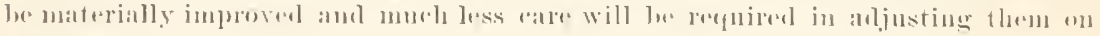
thiv grass.

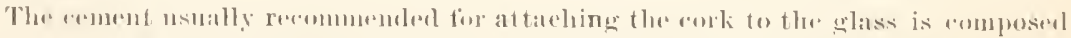

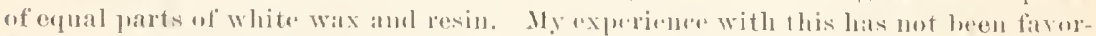

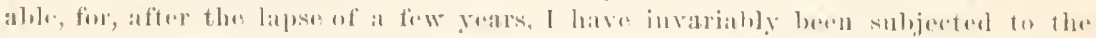

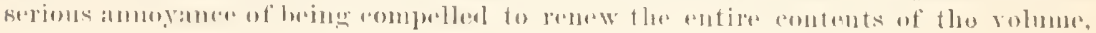


"l*an the glass, and replace the corks with new cement. From some canse, inexplicable to ne, a gradual s'paration takes place of the cork with its cement from the gliss, first appearing at the angles of the cork, and its progress indicated hy an increasing number of iridescent rings which form within until the "'nter is reached, when, if not previously detached, the iusect falls with the cork, nsually to its injury and that of others beneath it.

A number of years ago I happened to employ, in attacling a single piece of cork in one of my cases, a cement originally male for other purposes, consisting of six parts of resin, one of wax, and one of Venetian red. Several frar's thereafter my attention was drawn to this piece by tinding it as firmly united as when at tirst applied, and at the present time (after the lapse of twelve years) it is withont the slightest indication of separation. Artiug upon this hint, I have, of late, used this cement in the restoration of a $11 m m_{1} I^{\circ}$ of $m 5$ eases, and with the nost satisfictory results. It is important that the rement, when used, should be heated (by a spirit lamp or gas flame) to as high a degree as it will bear withunt burning. An amount suficient to cover the bottom of the small, flat metal vessel containing it to the depth of an eighth of an inch will suffice anl prevent the cork l'rum taking up more than its requisite quantity. It shomld be oceasionally stirred to prevent the precipitation of its heavier portions. The cork nay be conveniently dipped by the aid of a needle inserted in a handle, when, as quickly as possible, it should be trausferred to the glass, for the degree of alhesion seens to depend upon the degree of fluidity of the cement. From some experiments makle by me, after the corks had heen attached as above, in heating the entire glass to such a resree as thoroughly to melt the cement until it spreads outward from beneath the weight of the cork, and then permitted to cool-the glass meanwhile held horizontally, that the corks night not be displaced-the results appwar to indicate that the above cement, applied in this manner on glass properly eleaned, will prove a permanent ond. It is searcely necessary to state that this methor is not arailable whrere the ghass has been bound as ahove.

Preparatory to corking the glass for the specimens assigned to it, the spaces reyuired tor them are to be ascertained hy arranging them in orrer on a cork surtice or otherwise. On a sheet of pilper of the size of the glass, perpendivnlar lines, of the number of the rows and at their proper distances, are to he drawn, and eross lines equal in number to the inserts contained in the rows. The distances of these lines will be uniform, unless smaller specimens are to occupy somr portion of the case, when they may be graduated to the recuired proportion. With the sheet ruled in this manner and placed beneath the glass, the points where the corks are to be applied are indicated by the intersections of the lines. 'The shcet, markerl with the family of the insects for which it was used and with the numlers designating its divisions, may he laid aside for futme use in the preparation of otler ases for which it may he suitable. In a series of unbound cases in my collertion, in which the glasses measure 11 br $1 \frac{1}{2}$ inches, I have nsed for my Lepidoptera and laid aside the following scales, the citation of which will also serve to show the capacity of the cases: 3 by 8, Catocalas; 2 hy 7 and 3 ly 9, Nhingide; 4 by 11 to 4 by 11, bombycidie; 5 liy 13 to 6 by 16, Noctuida ; by 16 and 8 ly 20, Lyesenda and Fortricidie.

The nnbound eases above roterred to are inexpensive frames, made ly myself, of quarter-inch white wood or pine, the corners mitered, glued, and nailed with threeyuarter inch hads, lined within with white paper (hetter with tin foil), and covered without with stout manila paper. The glasses are cut of the size of the frame, and when placed in position thereon are appressed closely to it hy laying upon them, near each rorner, a heavy weight, and strips of an enameled green paper, cut to the whth of I inch, are pastrel over their elges, extending a little beyond the thickness of the frame, and bronght downwarl orer the outside of the frame. On its late two gum labels, indicatung the insects inclosel, are placerl at uniform heights (7 and 12 mches), when, if all has been neatly done, they present a tasteful appearunce "pon a shelf. When there is reason to helieve that the case will need to bo opened 
for the change or addition of specimens, it will be found convenient to emplos, for the fastening of the left-hand side of the upper glass, paper lined with a thin muslin, to serve as a hinge when the othur sides have heen "ut.

Should it becoume desirable to bind these cases, outside frames may be construeted after the plans above given, with the onnission of the insidn ynarter inch (the equiralont of these frames), in which these may be placed and held in position by two or three scruws insertal in their silles.

The Mertiudale Box for Lepirloptere.-Mr. Isaace C. Martiudale, in the Octobes, 15!11, number of Entomologiral Texes, 101. 126, 127, deseribes a new form of ("allinet for butterflies, the thawers of which present seme mew fratures. 'They are for the same end as the I intner box described above-manely, for the display of the upper and muler surface of the wing of Leproptera, and promise to be more nsetul. The drawar is described as follows:

The "special feature is the drawer itself, which, insteal of having a cork hottom, as is usually the case, has both the top and hottom of glass. The top part of the drawer frame fits tightly over a ledge one inch in leight, effectually preventing the intrusion of destruetive insects, the pest of the antomologist; lut it is readily lifted when it is desirable to add to the contents or change the location of the specimens. For the iuside arrangement I have taken a strip of common tin, one inch wide, and turnerl "u each sille tive-sixternths of an inch, thus leaving three-eighths of an inch for the bottom. The length of the strip of tin, being about two inches longer than the wilth of the drawer, admits of each end being tmrned up one inch. Into this tin trough is tightly fitted a cork strip three-pighths of an inch square. The whole being corerol with white paper, such as is usually used for lining drawers, conceals the inequalities of the cork and makes a fine finish. They shomld he marle to tit neatly in the dlaw re, and an be readily moverl abont to suit larec or small specimens. For Lyconas, I'amphilas, otc., as many as fifteen of these strips may he nsed in une drawex, and as few as five for Jorphos, Caligos, ete. The upturned eurls are fastened in place by using the ordinary thumb tacks that "an be procured at any stationer"s. The frame work of the drawers shomld be of white pine, well seasoncl. Into this the tlumb tacks are readily inserted and as casily withdrawn when a change in the position of the "ork strips is needed.

Horizontal r.s. rertical Arrangement of Boxes.- l have elsewhere dis"usser the avalability of the mpright rs. the lumizontal andugement of insect boxes.* In the case of Lepirloptera and large-borlied insects I have fomm the horizontal drawer of box to be preferable. It lasegeborded inserets are placed in a vertical pusition they are very liable to hereme loose on the pins, swing fiom side to side, and damage then-

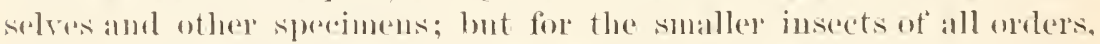

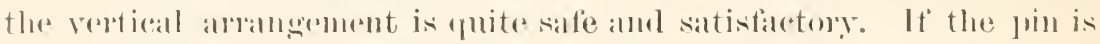

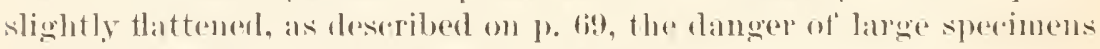

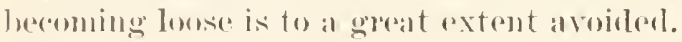

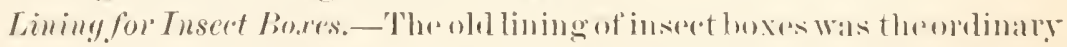

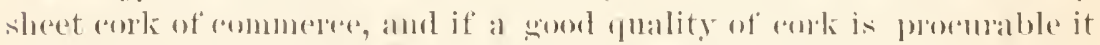

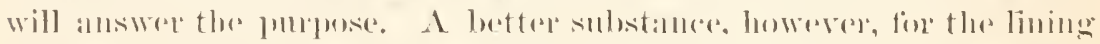

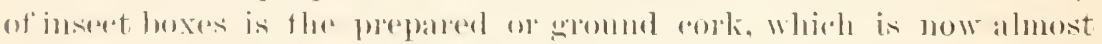

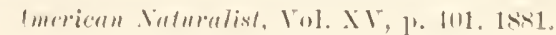


exchusively used. It is simply gromol cork mixed with a small amount of ghe. compressed into sheets and covered with palper. This gives a rery homogenous composition, and is much better than the ordinary eork, having a more nniform and neat appearance, and admitting the insertion of the pins more freely. It mar be purehaserl from H. Herpers, 18 Crawford street, Newark, N. J.

A less expensive substitute is paper stretehed upon a frame. Prof. E. S. Morse has given in the "Ameriran Naturalist" (Tol. i. 1. 1.56) a plan which is rery neat and useful for lining boxes in a large museum, which are designed to be placed in horizontal slow-cases (Fig. 120). -A box is made of the required depth, and a light frame is fitted to its interior. Cpon the mpper and moler surfaces of this frame a sheet of white paper (drawing or log paper answers the purpose) is securely glued. The paper, having been previonsly damped, in drying contraets and tightens like a drumhearl. The frame is then secured abont one-fourth of an inch from the bottom of the box, and the pin is forced down through the thicknesses of paper, and if the bottom of the box be of soft pine, the point of the pin may be slightly forced into it. It is thus fimly held at two or three different points, and all lateral movemnts are prevented. Other anvantages atre secured by this arrangenent besides firmuess: when the box needs cleaning or fumigation, the entire collection may be removed by taking ont the frame; or eamphor, tobaces, or other material 'an be placed on the bottom of the box, and concealed from sight. The annexed fignre represents a transierse section of a portion of the side and bottom of the box with the frame. A A, box; B, frame; P P, upper and under sheets of paper: C, space between lower sheets of paper and bottom of box."

Other substitntes are the pith of varions plants, especially of corm. Palm wood and "inodorous felt" are also nsed, being cut to fit the bottom of the box.

Pita wood or the light porous wood of the Agave or C'entury plant when cut into proper strips also makes a very light and satisfactory lining, while good close bog-peat cut into proper thicknesses is not infrequently used in France and Germany. Druce \& Co.,68 Baker street, London. WT., England, have lately been manufacturing what is known as cork carpet, which seems to be a combination of ground cork and mbber. It comes in varions colors and of the proper thickness, and makes a very smooth and desirable lining. holding the pins very firmly. 
It cost 90 cents per spmare yard in England, and I have had one cabinet lined with it as an experinuse as theme is a probability that the pins may corlode in contact with the rululere.

\section{ARRANGEMENT (IF INSEOTS IN THE I'ABINET.}

Systematic and biologive collections. - The permanent arrangement of specincus in boxes and dhawers will varysomewhat with the nature of the inserts. The almost miversal rostom of collector's, howerer, is to allange the insects in rertical rolnmms. In the case of the smaller forms, as Coleoptera, Hymenoptera, Diptera, 212 to 3 inches in width is allowed for the rolumms: and for the larger insects, as Lepridoptera, Orthoptera, for which larger drawers are recommended. a greater width of column is needed and $4 \frac{1}{2}$ to 5 inches will be found necessiry. With alcoholic material, a similar arangement in columns may be followed.

In spacing or dividing insect boxes into columus for the arrangement of specimens, I have followed the plan of pinning narow strijs of colored paper in the boxes at regular distances to divide the colmmms of insects. A fine line made with a medium pencil will answer the same pmrpose and will not materially disfigme the box.

The appearance of the collection will largely dejend on the care used in the alignment of the specimens, both vertirally and horizontally. It is advisable to have at least four specimens of a species, whirh, entomologically speaking, constitute a set. The vollector, howerer, shonld not limit the number of his specimens to fomr, as it is fiequently necessary to have a larger mumber to represent, firstly. the suxes: secondly, varieties; and thindly, geographical distribution.

In the systematic collection the species shonld be arrangerl serially in accordance with the latest catalogne or momograph, and if the oullector intends making a complete study of the gomp, space shomld be left tor the subserpent insertion of speries not at present in his possession and also for new species. This will avoid the rearrangement of the entire collection at bicf intervals.

Economic Displays.- In the case of eromomic displays. which will incelude pinned spereincus, alvoholic material, early states and sperimens illustrating the work of the insect-also the parasitic amol predaceoms enemies-the horizontal an'angencent wan be followed, and l have foums it arlvisable, in making snoh displays, to atrange them in this manmer, so that any needed width for the display of palticular sjeredes maly he

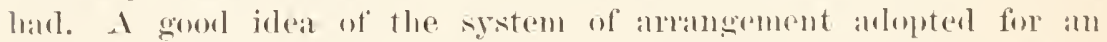
ecomomice exhibit may be ohtained fiom the areompanying illustration

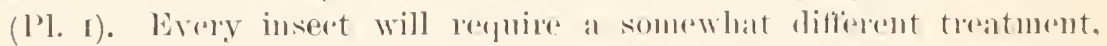
owing to its different labloit, but the plan inclioated in the illustration

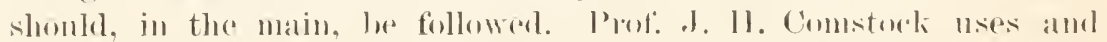

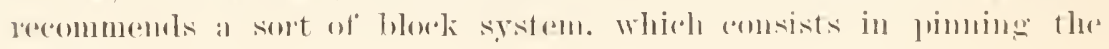


insects and specinems showing their work, and alcoholie material, to blocks of sott wood. These are then armanged in the display rases. The arrantage rlaimed for the system is facility in transferring and rearranging the exhibits. This method is somewhat rumbersome, and in making and handling economie exhibits I have fouml pimning speeimens directly to the cork lining of the box, as already deseriberl, to be entirely satistatory. A biologic exlibit shonld be rarefully planned beforehand, and when onee completerl is permanent and does not require rearrangement, as is frequently neeessary in a systematic collection, owing to the constant ehanges in classification. The my alteration necessary is a renewal of specimms whirh have become injured, or fadled hy exposure to light.

Labeling Collections. - I have allearly fully discussed the subjuet of labeling insects before placing them in their final resting place in the eollection. In the collection certain additional labels are required, viz, labels for the order, family, subfamily, gents, species, and sometimes variety. The label for the order should be placed ahore the first species in the collection, and shonld he in lange trpe, as shomld also be the name of the family, which is to be plated above the first species in the family. The gems label should be in prominent type, somewhat smaller than the fomily label, aml should be placed at the head of the genus. Custom varies as to placing the lathel of the species. In my practice I have arlopter the plan of plateing the label below the series of specimens representing the species. Some entomologists reverse this plan and place the label above the series of specimens. Others recommend pimning the label to thr first and besteletermined specinen of the series. This las the advantage of' always kreping the label with the speries ant preventing the danger of mistake or confusion of the latter. In the ease of large inserts, however, this plan has the clisadvantage that the label can not be sern except by taking ont the specimen, and, on the whole, the plan which I have adopted of placing the label below the series of specimens is preferable, but may be supplemented by the other, as in addition to the independent label, one of the specimens should have a label pinned with it. The labels should be neatly witten ou blanks printed for the purpose; but a better plan. perhaps, and one which I have followed, where possible, in labeling the national collection, is to eut the names neatly from a eatalogne of the insects, which will furnish all the labels from order tospecies, and finsten them with short, ineonspicuous pins in their proper places in the rollection. Where it is not desired to keep the collection as compact as possible, or where one has limited space, $]$ womld advise labeling the species, not only with the recognized name, but also with the symonyms. This refpuires some space, and will hardly be followed except in public collections. It is also desirable to arrange together, and label as snch, the varieties of any given species. The appearance of the collection will depend largely on the miformity of the labeling, and tom much eare can not he exercisen in this respeet. 


\section{MUSETM PESTS, MULD. E'TC:}

Enfortmately for the well-heing of collections, dried insects ane liable to the attarks of varions musemm pests, the most tronblesme of which are thrmaseres insects, but altogether ont of their proper place and role in the gencal collection. Tuless constant preantions are taken, the colloretor will discover after a few months that insteal of the rare specimms with the preparations of which he has taken mo little pains there remains only a series of fiagmentary specimens, which a few years" noglect will redure to little more than a mass of dust or powror. The prive, them, of a good collection is eternal rigilance. Most insects, when "xposed for any length of time to strong light, fade or lose color, aur the omly way to prevent such achomatism is to exchule the light.

luseot pests affecting collections inclule Psocidar, Mites, Tineirla, Coleoptera of the families Ptindar and Inemestirlat, these last heing the most injurious.

The Psocidac-degladerl wingless insects aldrably referred to in the elassification (p. 24)-will fund their way into the tightest boxes, lunt ordinarily do little if amy damage, exeept in the case of delicate

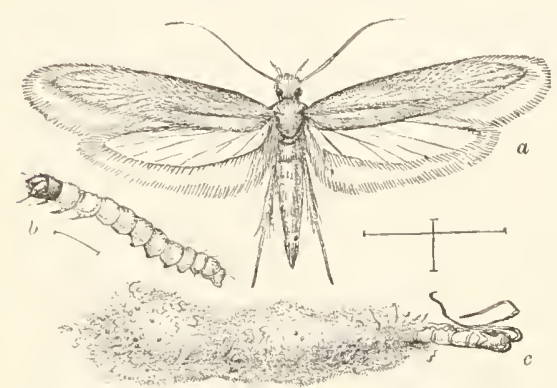

FI4. 22l.-Tineola biselliella: $a$, alult; $b$, larva: $c$. cocoon aud empty jupa-skin ealorged. iusects, such as Ephemerisls, Mi-

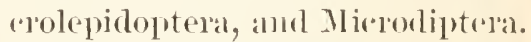
The common forms fomm in collecetions are Atropos divinatorius and Clothilla pulsotorin. Mites or Aeari are rarely troublesonse in collections, thomele Dr. H. A. Hagen lepolts having formul a sprecies (probably of Tyroglyphus) with imported inserts, and (a)msiders them as liable to become dangerous encmies. Tinciul larve are ramy found in collections, and only affect the larger moths. They are not easily diseoverenl, since they make mo dust. as do most other pests. Some persons lase been considerably annoyed by ane of the commom elothes notlss, Tineola biselliella (Fig. 121). Dr. Hagen foumb that it attarked freshly collereted or urwly spread inserets. where the

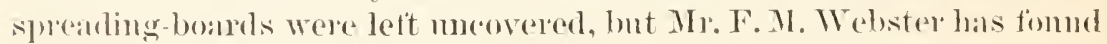
it injurions to the general collections at Colmulus, Ohio.

Of beetles, the Ptindie ale sometimes fomd ju collections but are

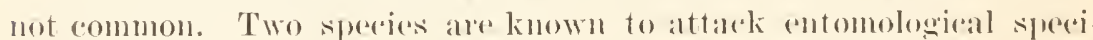

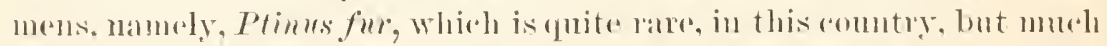
more abmulant in Europe, and Tribolinm ferrogmemm, a cosmopolitan

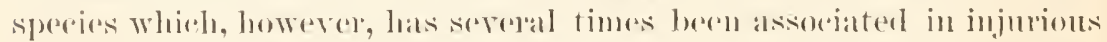
mumbers with lange collections of inserets importerl fiom the East Intiris.

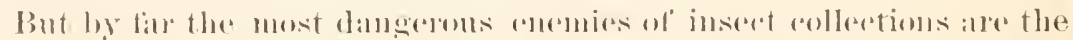


larve of some half dozen or more speeies of Dermestidie belonging to the genera Anthrems, Attagems, Trogoderma, and Dermestes. of these Anthrenus varius is the more eommon pest, in musenms, especially in the North and East. In the Sonth and West Trogoderma turewe and T.ornutum (?) replace Anthreuns. The Enropean species Anthrenus muscorum, is, on the anthority of Hagen, rare in this comtry, and probably ocenrs chiefly in collections of imported insects. It is the common injurious species of Europe. Anthrenus serophularia (see Fig. 67) oceurs also in collections, Dr. Hagen stating that he has found it nearly as common as A. rurius, and certainly more dangerons. In my own experience it is rarely found in insect collections. Two species of Attagenns (A. pellio and A. megatoma) have also been fouml in collections. A. megatoma has been fonnd by Dr. Hagen to do not a little damage to insect collections in Cambridge, as well as to eonal if not exceed the Carpet Beetle in its disastrous attacks upon carpets and honsehold furniture. The other species, A. pellio, is rarely found in this comtry, but is mueh more eommon and obnoxions in Enrope than A. megatoma. Dermestes lardarins is sometimes found in collections, and is attracted by the presence of animal matter such as skins, ete. The two particuliarly destructive pests, as prointed out, are Anthremus corins and Trogoderma tarsale. These species, together with most of the others, have no definite breeding period, but, in the miform temperature of the laboratory or musem, breed all the rear round and present no definite broods. It is the experience at the Mnseum that the boxes on the lower tier of shelves are very much more subject to attack than those on the upper tiers, from which it wonld scem that the parent beetle deposits her egg's ontside the boxes on the floor of the cases and that the young larve work their way into the smallest rrevices. The danger of infection by these pests is greater in warm climates like that of Washington than in regions further nortl, as the warm season begins earlier, lasts longer, and furnishes better conditions for breeding and multiplication.

REMEpIEs.-The following remedies and preventives will prove efficient in checking or preventing the work of these pests.

Saphthuline.- Where tight hoxes are employed little fear of the work of these destructive agents need arise, especially it the boxes are kept supplied with rejellent nalphthaline cones. These are hard cones of naphthaline, momnted on pins for convenient placing in the boxes (nee Fig. 122), and may be obtained of dealers in entomological supplies. Naphthaline cones act as repellents to these

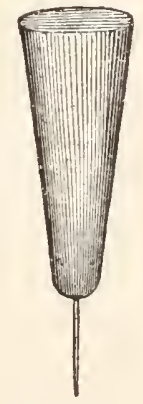

Fic. 122. A napibthaline insects and also to some extent retard the development of the larvad in all stages and particularly of the eggs.

Mr. Sehwarz states (F'roc. Ent. Soc. of Washington, Vol. 1, page 63) that in place of these cones a form of naphthaline may be used which 


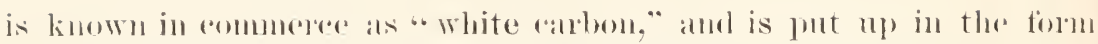
of small seflate lods for use in intensifyiug the flandes of gasleght. The material is very chealp, costing only is conts per pomml wholdsile, and

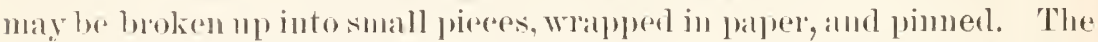
nse of naphthaline cones is not advisable in boxes containing delicate specimens, as it leaves a doposit which dulls the colors and enoenuges

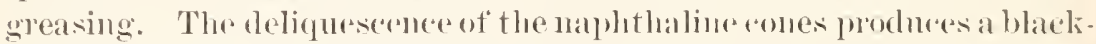
ish, oily residnum whinh will soil the lining of the box, and it is always

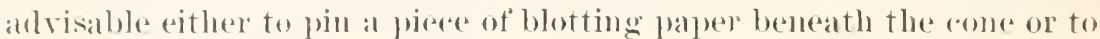
walp this in palper.

Constant watchlolness is necessaly to see that the eggs which have berm deposited amd checked in development ly the applieation of this insecticisle do not ultimately hateh and start a new generation in the insecet box.

bisulphide of ('mbon.-It the collection is fomd to be infested with inseret pests, it may be lenovated by pouring a little bisulphide of arlon into the boxesand closing them at once. This substanerevaporates laluielly and will destroyall jusect life, amol does not injure specomens or pius nol stain the boxes. If infested specimens are recoived, these shomld be inclosed in a tight box and treated with bisulphile of callon before being alded to the genedal eollection, and it is alwas woll for those who arr receiving pinned specindes by exchange or otherwise to lieep a quarantine box of this kind on hand.

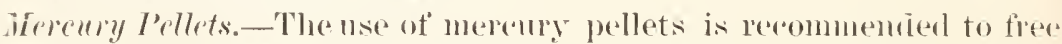
boxes from Mites, Psoci, ete.. and also to collect any particles of dust which may gain entrance. A few small pellets of mementy placed fires in the hottom of the horizontal box will, hy the movement of the box.

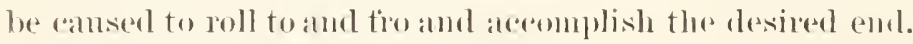

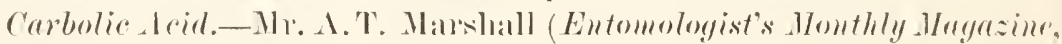
Dere. Is7:3, 1) 176) lecorels that he washes the papere of his boxes with

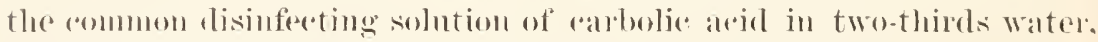
which dores withont staining and protects the specimens flom l'soci.

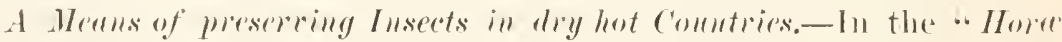

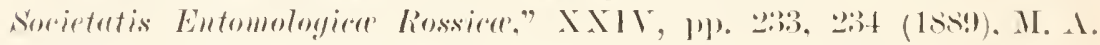
Wilkins, whing fiom Tarblient in Turkestan, alludes to the ineticieney of orelinary fueservatives in Central Isia, on areount of their

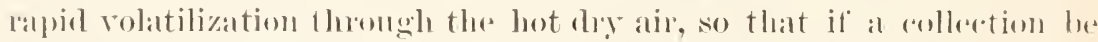

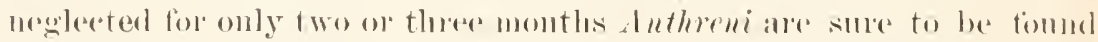
in the hoxes. Ho has hit mpon a plan whirh he finds efteretive, and at the same time very simple. He employs lublia-pubber batuds about 1. imbes in wirlth and lesis than the length ot the boxes to which they are to be appliod. These bands ane strotehed over the opening line of the

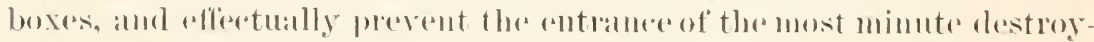
ars. Posibly a similar plan might be alopted in otlere romutries with

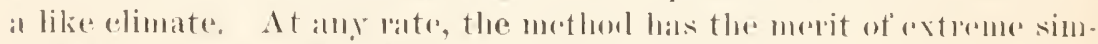

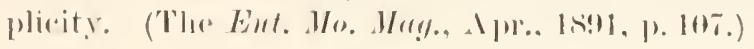


IIULI).

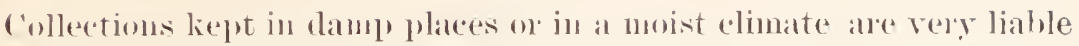

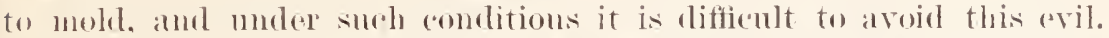
Carbolic aciol is recommended, but Mr. Ashmead, who has kept a latrege collection in the moist elimate of Florida. has fomnd the mese of naph hthaline much non's satisfactory. Mr. Herbert H. Smith who has had more extensive experience in the tropics prefers the ambolic arda. Moldy sperimens may he cleansed by washing with arbolie acd applied with a finc camel's bair butsh.

\section{TERDIGRISING AXI) (TREASING.}

The artoon of the acid juices in the bodjes of ereptain specinens-as many of the Lepidoptera, Coleoptera, and loiptera-will canse the formation of verligris about the pin. Whioh in time alecumulates and risfigures and disforts the suevimen, and ultimately romoles the pion so that the slightest tomele rauses it to bend or breale. 'There is mo presrentive yet known lore this tromble othere than the use of pias which have no brass to be entorled. Japanued pins are made for this purpose, and ane. on the whole. satisfactory, hut they lund easiy and some wan-

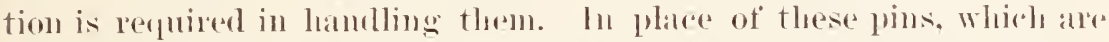
somerolat more expensive than the steel pins, inom pins may he nsed. These ale very soft and bend ton easily for satisfactory use. The steel pins may be reudered available for use by an inmersion in a silver bath, which is (omplatively inexpensive.

Insects the larve of which live in wowl ane particularly subject to ver-

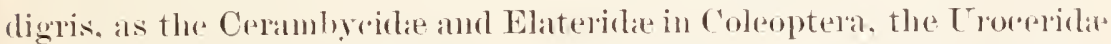
in Hymenoptrat and sesiidae in Lepirloptera. In Hymenoptera the tamilies Formicide. Mutillide, and the endophytous Ienthredinidar verdigris rely lapblly, and most Diptera also. With all these insects jatpammed or silvered pins slonld be used, or when not too barge the insects shomld be monuted on triangles. This repligrising is associated with what is known as gleasing, and this, as just indicated, is also associaterl with endophytom larval lite. The verdigris may be pore vented by the methods indirated, and I would strongly advise, as a good general rule to be followed, the rejection of the ordinary pins for all species which, in the larva statr, are internal feeders. But there is uo way of purenting greasing or decomposition of the fats of the body, which may aftect a specimess reals after it has becen in the cabinet. If the sperimen is valuable the grease may beabsorbed by immersion in ether ol benzise, or by a longer treatment with powetered pipe-chay or plastre of Paris. Inserets collereded on seabeaches, and saturated with salt water, also corrode the common steel pin verr quickly and slomld be momted on japamed pins. It is also advisable to rinse such specimens thoronghly in fresh water before momting.

The conviction has been forring itself on my mind for some time that the maphthaline cones tend to promote srosing and verdigris, am carbolic aciol in some small vessel secoled to the cork, were, perhaps, preforable. 


\section{THE REARING OF INSEGTS.}

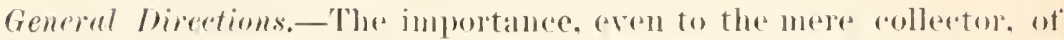
rearing inserts to obtain specimens for the abbinet has been refereed to fiom time to time in these pages. The plubsolubre study of entomology, howerer, requiles num more than the mere collecting of sperimens, and onr of the most profitable and, at the same time, most fascinating phases of the study relates to the life-listory and habits. fu no branch of natural history ale biologic stmdies mole catsily calried on. or the biologic tarts more remarkable or interesting. The systematist by such study will be savel from the narow and hali-s]litting tendencies which sturly of slight difference of charactors tends to, while to the economic entomologist it is most essential.

In the rearing of insects success will be attained in proportion to the extent to which the conditions of nature in the matters of temperature. moisture, food-suplyly, and conditions for pupation, are observed.

". In the handsof the canceful breeder an insect may be secumed against its numerous natual enemies and against vicissiturles of elimate. and will, conseguently, be mole alyt to mature than in al state of nature. The breeding of aquatic insects reguires afuaria, and is alwap̧s attended with the difficulty of furnishing a proper supply of foud. The transformations of many others, both aquatic and terrestrial, can be studied only by alose and careful ontdoor observation. But the weat majolity of insect larve may be reared to the perfect state indoors, where their manenverings may be constantly and conveniently watehed. For the feeding of small species. glass jars and wide-nonthed bottles will be found useful. The mouths should be rovered with ganze or old linen, fastened either by thread or lubber. and a few inches of moist earth at the bottom will furnish a retreat for those which enter it to transtorm and keep the atmosphere in a moist and fit condition.

The Breeding Cage or Tivarum.-.. For larger insects I use a breeding cage or vivarimu which answers the pmpose adminally. It is represented in figme 123, and comprises three distinet parts: First, the loottom board a, consisting of a sfuare piece of inclu thick walnut with at rectangular zine pan $f 7,4$ inches deep, fastened to it above, and witl: two cross pieces yg below, to prevent rakking or warpind, faldilate lifting, and allow the air to pass molerneath the cage. Sierond, a box $b$ with-three glass sides and a glass door in front, to fit over the zine pale. Third. a cape e, which fits elosely on to the box, and has a tol' of fine wire sanze. To the renter of the zine pan is soldered a zine tube a just large "nough to rontain an ordinary quinine bottle. Thre zine pan is filled with rean sifterl earth or samel e. and the quinime bottle is for the reception of the food plant. The "age admits of alumdant light and air, and also of the asy removal of exrement or thass which falls to the ground; while the inserts in transforming enter the

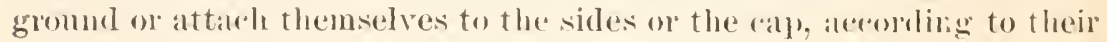


habits. The most convenient dimensions I find to be 12 inches square and 18 inches ligh: the rap and the dool fit closely by means of rabbets, and the former has a depth of about 4 inches to admit of the largest cocoon being spun in it without tonching the box on which it rests. The zinc pan might be made 6 or 8 inches deep, and the lower half filled with sand, so as to keep the whole moist for a greater length of time."

The sand or earth in the zinc pan at the bottom of the breeding cage shomld be kept constantly moistened, and in the ease of hibernating luly the constant adding of water to the top of the earth or sand causes it to become very hard and compact. To overcome this objection it was suggesterl in the Entomologists' Monthly Magazine for June, 1S76, page 17, that the base should be made with an inner perforated side, the water to be applied between it and the onter side, and I have for some rears employed a similar double-sided base, whieh answers the purpose admirably (See Figure 12t.). It is substantially the same as that made for the Department hy Prof. J. H. Comstork in 18\%9. It consists of a zinc tray ", of two or three inches greater diameter than the hreeding cage, which surrounds the zinc pan propereontaining the carth, and the tube $d$ for the reception of the food-plant. The lower portion of the inmer pan $b$ is of yerforated zinc. Zinesupports, $c c$, are constructed about halfway between the botton and the top of this pan, on which the breerling cage rests. In moistening the earth in the cage, water is poured into the tray, which enter's the soil slowly, through the perforations in the zine pan. 1 have foumd this modification of very decided advantitge and use it altogether in the work of the Division, and heartily receommend it.

The base of the vivarinm or breeding eage shonld never be made of tin, but always of zine. If made of tin, it will soon rust out. Galvanized iron may be

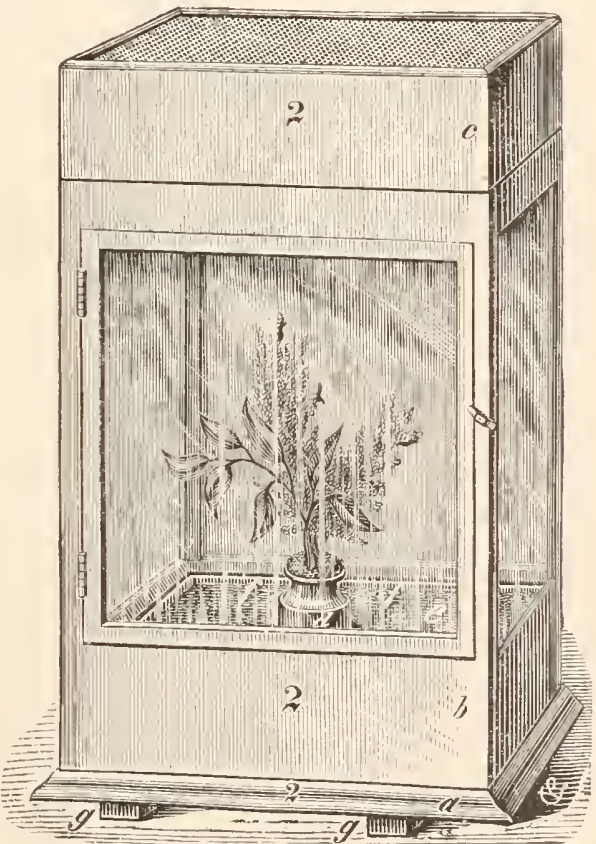

FIG. 123.-Insect breeding-cage or vivarium. used in place of the zine, and will dombtless prove equally satisfactory. 
"A dozen surh cages will furmish room for the ammal breeding of a great number of speeies, as serenil having different habits and appearance, and which there is no danger of confomding. may be simmltameonsly fed in the same cage. I number each of the three parts of wach cage to prevent misplacrment and to facilitate reference, and aside from the notes mate in the notebonk, it will aid the memory and expedite matters to keep a short men record of the species contained in each cage, by means of slips of paper pasted on the ghass door. As fist as the different specimens complete their transformations and are taken from the eage the notes may be altered or erased, or the slips wetted and removed entirely. To prevent possible ('onfoumling of the different species which enter the ground, it is well, from time to time, to sift the earth, separate the pupe and place them in what I call 'imago cages.' used for this purpose alone and not for feerling. Here they may be arranged with referencos to their exact whereabouts.

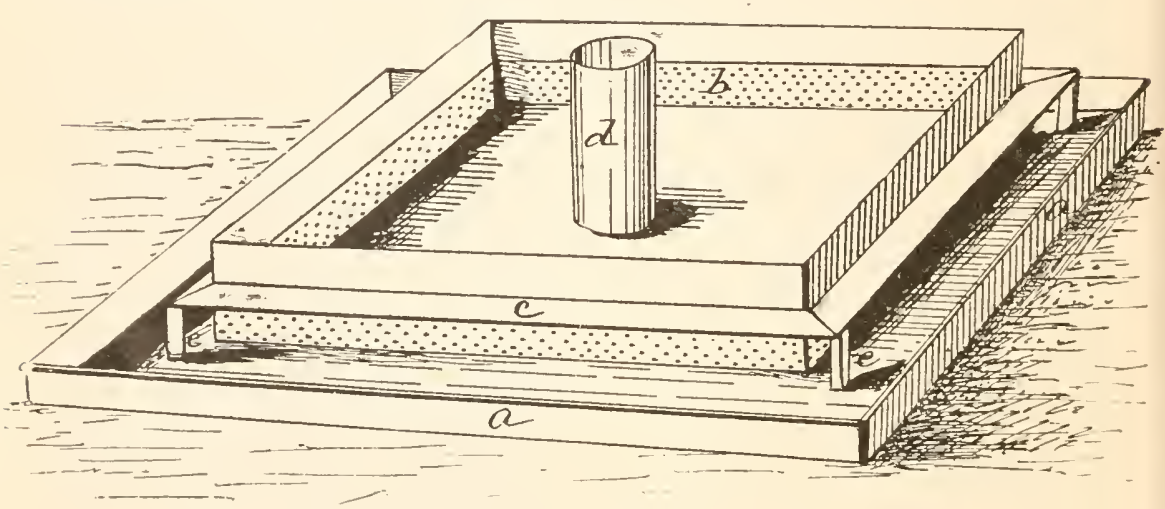

Fra. 124.-Inproved base for breeding-eage (original).

"A continued supply of fresh foor must be given to those insects whirh are fexling, and a bit of moist spomge throst into the mouth of the bottle will prevent drowning, and fornish moisture to such as need it. By means of a broal jaste bush amel spoon the frass may be daily remover from the "arth, which should be liept in a tit and moist condition-neitler too wat nor too dry. In the winter, when insect life is domant, the earth may be covered with a layer of clean moss, and the rages put away in the cellar, where they will noed only oecasional inspection, hut where the moss most neverthehess be liept damp). Cages matle after the same plan, hut with the sicles of wire ganze instead of glass, may be nsed for inserets which do not well bear confinement incluors, the cages to be placerl on a platform on the north sicle of a honse, where they will reseive only the early morning and late evering silı." 
Detuiled Instructions for Redring.-In the rearing of insects every worker will develop a number of methods of value, and it is ouly by careful study and comparisom of the experiences of all that the best system can be elaborated. For this reason I have, in what follows, quoted, in a more or less fragmentary wity, the experiences of different entomologists.

As is rematked by Miss Murtfeldt, in an interesting paper read before the Entomological Club of the American Association for the Arrancement of Science, August 20, 1890, "there is a great individuality, or rather specifirality, in insects, and not infrequently specinnens of lalvie are found tor which the collector taxes his ingenuity in vain to provide. Not the fireshest leaves, the cleanest swept earth, or the most well-aired cages will seem to promote their development."

The greatest care and watchfulness, therefore, are necessary to insure success in the rearing of larva. In many cases such larvie can only be snceessfully reared by inclosing them in netting on their food-plant ont of doors. It is a frequent deviow of Lepidopterists also to inclose a rare female in netting placed on the food plant of the spereses, where the male may be attracted and may be canght and places in the bag with the female. when eopulation usually takes place sucessfully, or a male may be eanght in the field and inclosed with such female. Mi. W. H. Edwards, where the plant is a small one, uses for this purpose a headless keg covered at one end with ganze, which he places over the plant inelosing the fermale.

Mr. James Fletcher, of Ottawa, Canada, one of our most enthusiastic rearers of insects, has given some details of his methorls in a recent very interesting aceount of "A Trip to Nepigon." One style of cage used by him in securing the eggs of latge Lepidoptera " is made by cutting two flexible twigs from the willow or any other shrub and bending them into the shape of two arches. which are put one over the other at right angles and the ends pushed into the gromud. Over the penthouse thus formed a piece of ganze is placerl, and the cager is complete. The edges of the ganze may be kept down either with jegs of with earth placed upon them." This kind of "age is used for all the larger species which lay upon low plants. The species which oviposit on larger plants or trees are inclosed in a gauze bag tied over the branch. This is applicable to inseets like Papilio, Limenitis, Grapta, etc. Care must be talien, however, that the leaves of the plant insirle the net are in a natural position, for some species are very particular about where they lay their eggs, some ovipositmg on the top of the leaves, others nair the tip, and many others on the under surface. "When a bag made beforehand is used, the points must be rounded, and in tying the piere of gauze over the branch care must be taken to pull out all creases and folds, or the insect will be sure to get into them and either die or be killed by spiders from the outside of the bag. It is better to put more than one temale in the same cage. I have frequently noticed that one 
specinen alone is apt to elawl about amb settle on the top of the eage. and not go near the foul plant. When there are two or theer they disturb each other and ale frepuently moring and talling on the forrl plant, when they will stop for a moment and lay an eges. A stubborn temale of Coleus enrytheme was only indurest to lay by having a male plated in the arge with her, and by his impatient fluttering and reforts to escape she was frequently linorked down from the top, and erery time she fell mon the clover plant benrath, she latil an egg before row wing to the top, again." Some inserets, even with all cale in making their smromolings as matural as posible, will persistently refuse to lay. Mr. Flotrher has successfully obtained eggs from some of these by a methou which he says one of his correspondents styles "Egg-laying: extraordinary." It consists simply in "gently pressing the abdomen of a female which has rlied withont laying eggs, until one and sometimes two perfect egus are passed trom the wijositor." Mr. Fletcher has secured a number of egas from lare species in this way, and successfully realed the larvac. The following directions for obtaining the eggs and rearing the lave of Lepidoptera, given in this paper by Mr. Fletcher, are excellent, and I frote them entire:

"There are one or two points which shonlel be remembered when ob. taining eges and rearing larvas. In the first place, the females should not be left exposed to the direot rays of the sun; but it will be found sometimes that if a butterfly is shuggish. putting her in the sum for a shont time will revive her aml malie her lay egges. Comfined females, whether over braneles ol potterl plants. shond alway be ju the open ail. If females do not lay in two or there days they must be fed. This is easily dome. Take them from the cage and hold near them a piece of sponge (or, Mr. Edwarls snggests, evaporated apple), saturated with a weali solution of sugar and water. As soon as it is placerl neall them they will arenerally move their antenme towards it, and, uneoiling their tongues, suck np the liquirl. If they take no notice of it the tongue cam be gently mueniled with the tip of a pin, when they will wearly always begin to feerl. It is better to feed them anay from the plant they ale wanted to lay mon, tor if any of the sime be spilled over the flowerpot of plant it is almost sure to attract ants. I licpet one female Colias interior in this way for ten days before egess were latid. Wlen

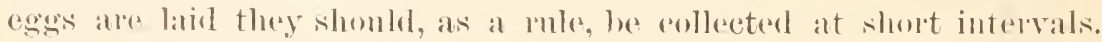

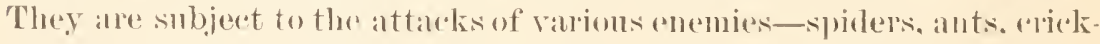

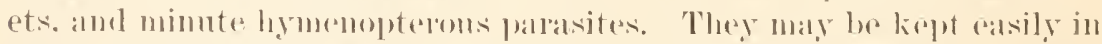
small boxes, but do bettere if not lirpt in too hot or dly a place. When

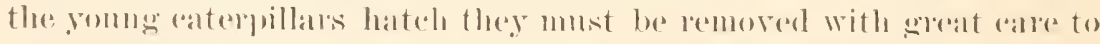
the foorl plant; a fine paint homsh is the most enomient instrument.

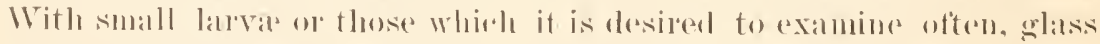
tuhes of jelly glasises with a tight fitting tin rover alle best. Tlesese

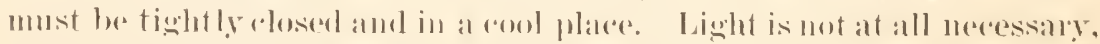

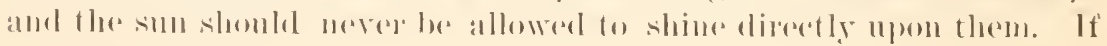


moistme gathers inside the glasses the top should be remover for a short time. Larvat may also be placed npon growing plants. These can be planted in flowerpots and the yommg aterpillars liept fiom wandering either by a cage of wire netting or, by what I have found very satisfactory, glass lamp chimmeys. These can be placed over the plant, with the bottom pushed into the earth, and then should have a lonse wad of cotton batting in the top. This has the donble effect of preventing too great evaporation of moisture and keeping its ocoupants within bounds. Some larve wander very much and elimb with the greatest ease over glass, spinning a silken path for themselves as they go. When caterpillars are bred in the study it must not be forgotten that the air inside a house is much drier than it is ont of door's amomgst the trees and low herbage, where "aterpillans live natmally. The amateme will require some experience in keeping the air at a right degree of moisture when breeding upon growing plints. In elose tin boxes or jar's, where the leaves must be changed every day, there is not so much trouble. An important thing to remember with larve in jars is to thoronghly wash ont the jars with cold water every day. If: however, a caterpillar has spme a web on the side and is humg np to monlt, it must not be disturbed. In changing the fool it is better not to remove the caterpillars from the old fool, but having placed a new sulply in the jar, ent off the piece of leaf mon which they are and drop it into the jar. It they are not near the montt a little puff of breath will generally dislodge them. Some caterpillars, as Pupilio turmus, which spins a plattorm to which it retires after feeding, can best be fed nuon a living tree out of cloor's, but must be covered with a gauze bag to kec'poff enemies. A piece of paper should be kept attached to each breshing jar or age. npon which regular notes must be taken at the time, giving the dates of every noticeable feature, particularly the dates of the moults and the changes which take place in the form and color at that time."

The necessity of outdoor work is further felt in the determination of the facts in the life-history of some insects which have an alternation of generations, as some Gall-flies (Cynipidue), and most Aphides. To successfully study these insects constant onthor observation is necessary, or the species must be inclosed in srreens of wire or netting outdoors on their foor-plant. Hany insects which breed on the ground or on low herbage may be very successfully watched and controlled by eovering the soil containing them or the plant on which they feed with a wire sereen or netting. The use of wire screens is also advisable in the case of wintering pupe or larve out of doors. Many species caun be more easily carried through the winter by placing them ontrloors under such sereens during the winter, which insures their being subjected to the natural conditions of climate, and then transferring them to the breeding cage again early in the spring. This is advisable in the ease of Mierolarva and pupae. Species which bore in the stems of plants may be easily cared for and leaf-mining and leaf-webbing forms 
ean be secured under screens or rovers ont of dool's for the winter in shroltered sitnations. Many species which, if liept in a warm loom can not be reared, will, if sulyectrol to freczing weather under slight protection in the open air, emerge snccessfully the following spring.

Thr gleatest care is necessary in the brecling of Tenthredinirla, as most of them transform under gromul and are single brooded, the larvae remaining in the ground from nirlsummer until the following spring. Nothing but constant rare in maintaining nniform moisture and temperatme of the soil will insure the suceess of such breeding. Some sperixs bore into rotten wood or the stems of plants to undereno their transformations, as for instance the longwood Saw-Hy (Hapiphorus varianus). This species, muless supplierl with soft or rotten mood in which to bone, will wander ceaselessly romnd the cage, and in most rases eventually perish.

Where a small room can be devoted to the pmpose, an excellent wholesale nethod of obtaining wood-boring inseets (Coleontera. Lepidopteru, ete.) is to collect large quantities of lead or dying wood of all sorts or any that indicates the presence of the early states of insects. and store it in such aprartment. The following spring and summer the escaping insects will be attracted to the winclows and may be easily secmed. The objection to this method is that, in many eases, it will be impossible to determine the food habit of the insect secured. owing to the variety of material brought together.

The Rowt r'uge.-For the stndy of insects which affect the roots of plants a rout eage has been deviserl hy Prot. J. H. Comstock which is of sulficient importance to warrant full description. It consists of a rinc frame (Fig. 1:Ju) holding two plates of glassin a vertion position and only a short distance alpart, the spare between the plates being filled with soil in which seeds are planted or small plants set. Ont side of each glass is a piece of zinc orshert iron (b) which slipsinto grooresalnc which ean be easily removed. When these zincs are in place the soil is knot dark.

The irlou of the cages is, that the spare between the glasses being very uarrow, a larege part of the roots will ramify rose to the surtace of the glass, so that by removing the zinc slides the roots may be easily seen, and any root-inhabiting inserets which it may be desirable to brecel maty thus be studied in their natmal anditions without distmbing thrm. Prof. Comstork has used this age very successfully in studying the hatits of wire-worms, and its availability for many of the molregromol inserets, surh as the Cicarlas, root-lice, larvar, etr., is apparent. These liames maly the made of vamioms sizos, to areommorlate panticulan inserets.

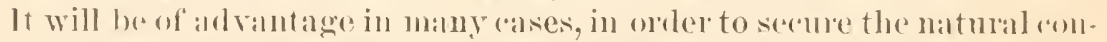
ditions as nearly as possible, to sink the adere in the soil, and for this purpose l'rof. Comstock las had romstrueted a pit lined with brick for the

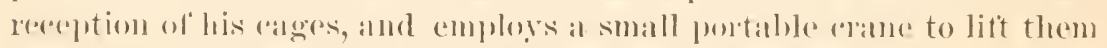
out of the gamel when it is desirable to examine thom. 
Other Apparatus.-Mnch of the breeding of insects can be done with the simplest apparatus, and for the rearing of Microlepidoptera, Gallinsects, and the keeping of cocoons and chrysalides of small species, noth. ing is more convenient than a medium sized test-tube, the end of which may he plugged with cotton. I have recently sucessfully carried over the winter the larvin of sphecins speciosus, which had been removed early in the fall from its earthen pod or cocom, the larva transforming to a perfect pupa in the spring. In this case the test tube was plugged with cotton and inserted in a wooden mailing tube to exclude the light. Smaller jars with glass cover's or with a covering of gauze may be employed for most insects, with the adrantage of occupying comparatively little space and of isolating the species under study.

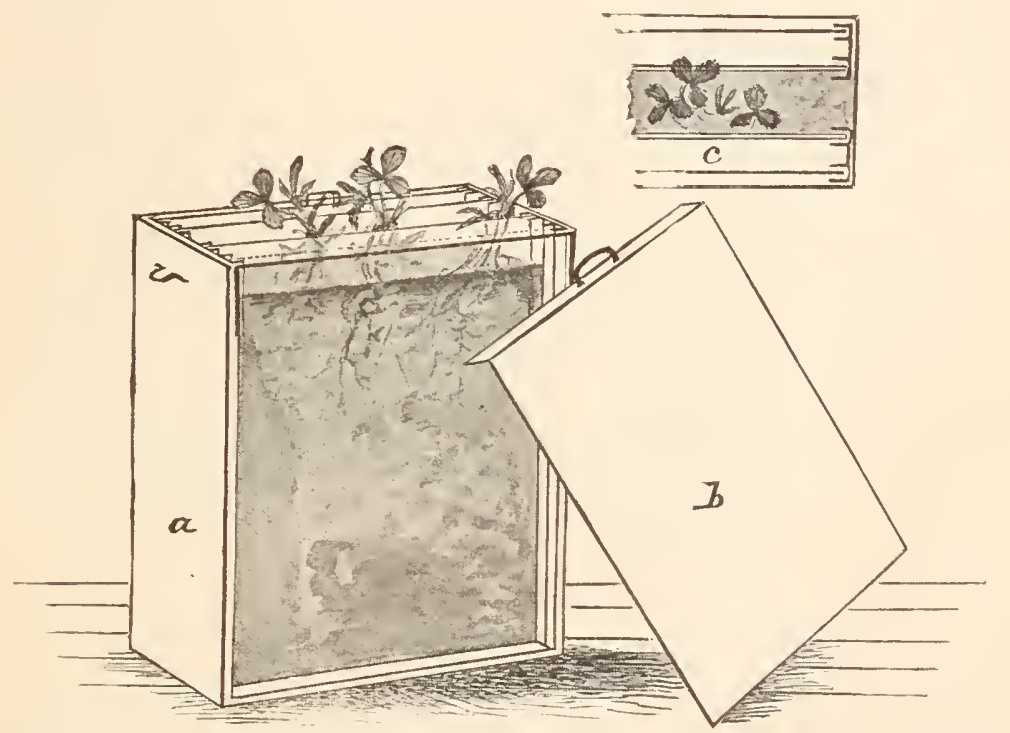

FIG. 125-Root cage: $a$, frame aith slide removed; $b$, movable slide; $c$, top viow (original).

Long glass tubes, open at both ends, are useful in many other ways, especially in the rearing and study of the smaller hypogean insects or those which bore and live in the stems of plants. An infested stem cut open on one side and placerl in such a tube will generally earry any insect that has ceased feeding, or any species like the woorl-boring bees which feed upou stored food, successfully through their transformations; while root-lice may be kept for a lengthy period upon the roots in such tube, providing a portion of the root extends ontside of the tube and is kept in moistened ground or water. In all such eases these tubes, with their contents, should be kept in the dark, either in a drawer or else covered with some dark material which can be wound around or slipped over them, and the ends must be elosed with cotton or cork.

The rearer of insects will frefuently experience difficulty in carrying his pupe throngh the winter, and, even thongh ordinary precantions are 
taken, the mortality will fiequently amomut to 50 per cent of the specimens. Mr. II. Bakhans, of Leipsic, thus rleseribes a device which is substantially the base of the vivarinm show on page 114.

"The base consists of a romel plate of strong zine, with two vertical rims, an inch high, placed one within the other, an inch apont, and solilerer to the basal plate so that the onter one is wateretight. The inner rim must be ferforated with small holes as elose to the bottom as possible. The spare inside the inner rim must be filled with finte sand, on which the prepe shomld be latid. The sjace betweren the two rims is then filled with water, which, finding its way thomgh the holes in the inner rim to the silnd, canses the nevessary moisture. Over the whole is put a bell-shaperl cover of wire gimze, which must fit tightly over the onter rim. In this receptacle the pmpe remain mutouched, and receive fresh moistur, as above indicaterl, if refuired by the drying of the sand."

The hamly pupe of most Noctuids and Bombycils, as well as those of many Rophalocera, may be handler with little ranger, but of hel species, if handled at all, or if the coevons which they male for themselves ale broken, can seldom be reared. Constant precuntions also must be exercised in the cale of the soil and the brealing eages. One of the great drawbacks is the presence of mites and threal womms (Entozoüns), ete., which affect dying or dead prepe and larve in the soil. They also affect living specimens and are capable of doing rery considerable damage. To free the soil of them it is necessiry at times to allow the earth to become dry enomgh to be sifter, anc. then aftris removing the pupie submit it to heat sufticient to destroy any undesired lifi there may be in it.

The Insectry.- Up to the present time the work of rearing insects has been largely confined to the breeding cage and breading.jar, alueady rleseribed, which have beon kept in the rooms of the investigator. The advantages of haviug a special building for this purpose are at once apparent and need not he insisted upon: One of the best astablishments of this kind is that of the Cornell University Experiment station, which was fully described in Bulletin No. 3, of that station, November, 18ss. The Kansas Exprument Station has a similar bulding. and one has recently been built for the use of the Entomological Division of the United States Department of Agrioulture. The insert-horeding homser or inseretary, shomld romprise a building having workmoms, or laboratories, for mieroseopic and greneral work in the sturly and preparation of speeineus, and also a (o) the growth of plants, and, where applion cutomology is concenond, special looms for the preparation and the test of insertiedes. The

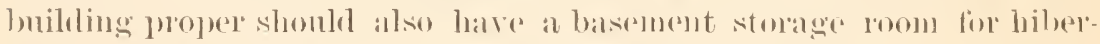
natimg insects. The labolatory shomld be fitted with all the applatatus

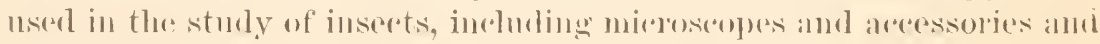
a dark-room for photosaraphic jumposes. 


\section{DIRECTIONS FOR TRANSMITTING INSEOTS.}

It is very desirable in transmitting insects from the field of exploration, or from one entomologist to another, for information, exchange. or other purpose, that they be properly secured and packed. l'immerl am monnted specimens should be firmly fixerl in a cigar box. or a sperial box for mailing, and this should be carefully but not too tightly wrapped with cotton or other loose parking material to a depth of perhaps an incl, and the whole then inclosed in stiff wrapping paper. It is prefer able, however, to inclose the box containing the specimens in a larger box, filling the intervening space, not too firmly, with cotton or other packing material. Where specimens are to be sent to a consiclerable

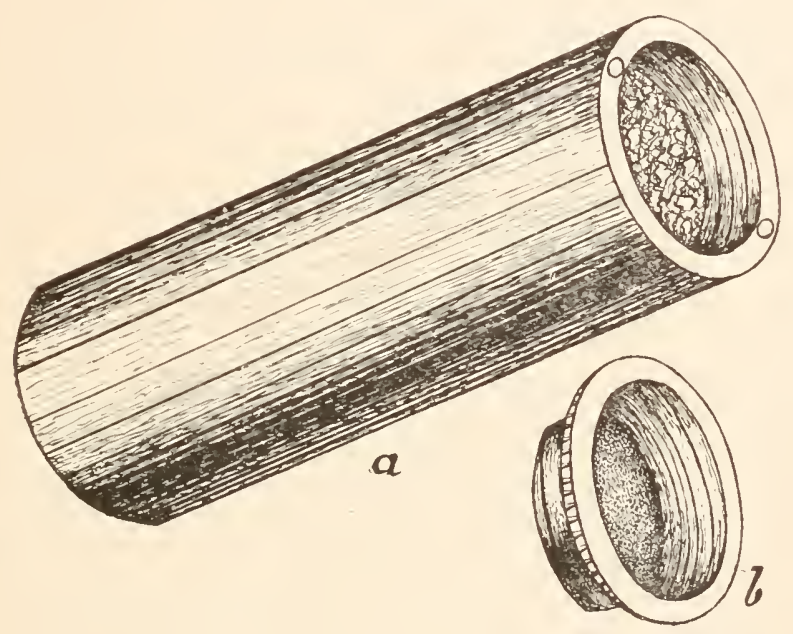

FIG. 126.-Wooden-tube mailing-box : $a$, tmbe; $b$, cover (original.)

distance it is advisable also to line the box in which they are placed with cotton, which serves to catch and hold any specimens which may become loose in transit. In the case of alooholic specimens each rial should be wrapped separately in cotton and placed in a strong wooden or tin box. Special mailing boxes foi alcoholie specimens have been derised, and a very convenient form is herewith figmed. It is an molinary tube of wood, with a metal screw top, and the interior lined with rongh cork. These tubes are made in various sizes to accommolate vials of different dimensions.

In mailing living specimens the essential thing is a strong box, pure ferably tin, made as nearly air-tight as possible. I have found it rery convenient on long trips to carry wit! me a number of tin boxes in the that (Fig. 127), combined in convenient packages, ready to be bent and implovised in the field. For this purpose get any tinsmiti: to make ont of good tin a number of pieces cut of the requisite dimensioms both for the bottoms and the covers, carefully cutting the corners to permit the proper bending of the siles. Thene improviser boses will prove 
useful for keeping living lanve with their food-plants. especially if tied up in stont brown paper to prevent any exit fiom the unsoldered angles. They will also answer admirably for mailing or otherwise send-
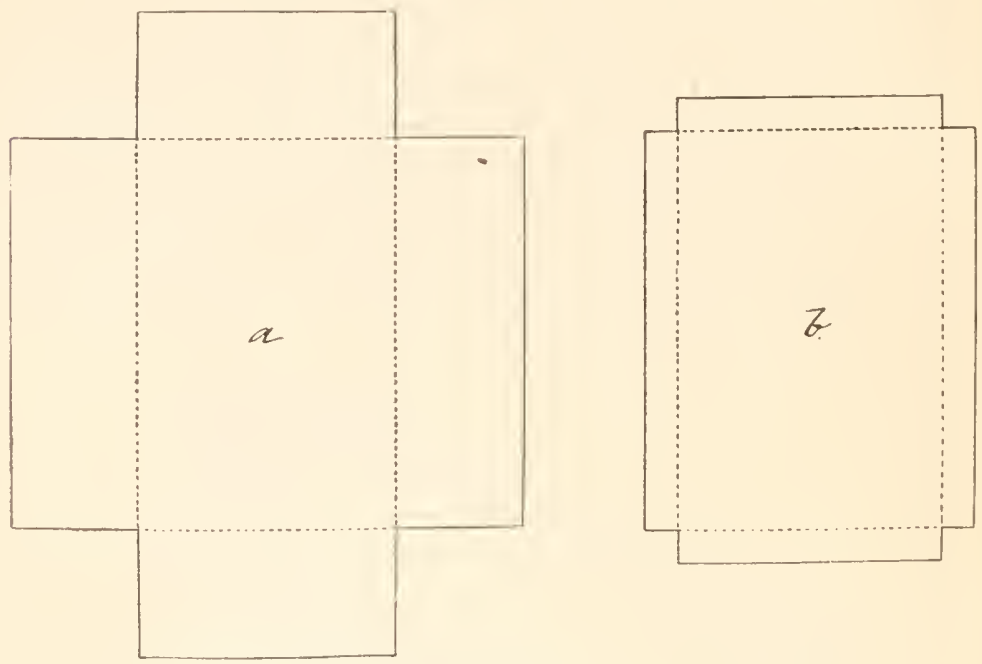

Fig. 127.-Tin mailing.box in the Hat: $a$, box; $b$, (w)er (original).

ing specimens to their ultimate destination. In the case of larve a quantity of the food-plant shonld always be inclosed in the box.

In transmitting insects for information the greatest care should be taken to relieve the person of whom information is songht of as much unnecessary work as possible. It is easy for any begimner to collect more in a single day than an experienced entomologist can well mount, study, and determine in a reek, and as those who have the means and infor-ation to give determinations or otherwise to assist beginners are generally very much oceupied, and their time is valuable, they are justified iu ignoring miscellaneous collectings where the sender has made no

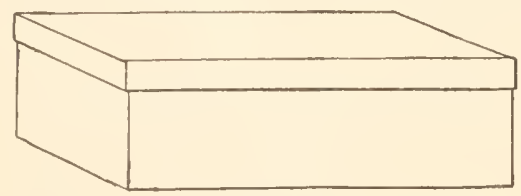

Fic. 128. - Tin mailing-box, bent into shape for ияe (original.) effort to eitlier projerly momut or otherwise study and care for his simerimens.

Livingspecimens, especially larve, should be packerl in tin. with a supply of their appropriate food. The tighter the bux the liesher will the foor as well as the specimens keep. Inserets do not casily sufforate, and it is wolse than useless, in the majority of msas, to punch air-holes in such boxes. Doad specomens, when not pimed, mat be sent in a valiety of ways. Small ones may lo dropperl into a quill and inelosed in a lettere, or a small vial titted inte a piere of hored wood. Those which do not sproil by wettiog may be sent iu alcohol, provided the bot- 
the is absolntely filled, or, what is better, in sawrlust moistened with alcohol, or between layers of cotton saturated with alcohol.

The postal regulations permit the sending by mail of "dried inserts

* * * when properly put up, so as not to injure the persons of those hambling the mails, nor soil the mail bags or their contents." Specimens in alcohol may also be sent by mail, provided that the containing vial be strong enough to resist the shock of handling in the mail, and that it be inclosed in a wooden or papier-machó tube not less than three-sixteenths of an inch thick in the thinnest part, lined with cork or other soft material, and with a serew top so adjusterl as to prevent the leakage of the contents in case of breakage. Entomologieal specimens are of the fourth class of mail matter, the postage on which is 1 cent an ounce or fraction thereof, the limit of weight for a single package being 4 pounds, and the limit as to bulk 18 inches in any direction. Salcable matter is also non-mailable at fonth-class rates; so that the safer method, with small packages, is to semf under letter postage. It is far better, however, for long jonrneys, and especially for transatlantic shipment, to send by express.

\section{NOTES AND MEMORANDA.}

In the foregoing pages are given some of the more useful direetions for those wishing to commence to collect and sturly insects. Experience will soon teach many other important facts not mentioned here, and the best closing atvice I ean give the norice is, to got aequainted, if possible, with some one who has alleady lad large experience. He will be very apt to find such a person pleasant and instructive company whether in the field or in the closet. Ons inportant habit, however, I wislo to strongly inculeate and emphasize: The collector should never be withont his memorandum or note book. Mlore profitless work can searcely be imagined than collecting natulal-history specimens without some specific aim or objeet. Every observation made should be carefully reeorded, and the date of eapture, locality, aurl food-plant should always be attached to the specimens when these are mounted. More extended notes may be made in a field memorandnm book earried in the pocket or in larger record books at home. For field memoranda I advise the use of a stylographic pen, as peneil is apt to rub and efface in time by the motions of the body. The larger record book is especially neressary for biologic notes. Notes on adolescent states which it is intended to rear to the imago ean not be too carefiully made or in too much detail. The relative size, details of ornamentation and structure, dates of monlting or transformation from one state to another-indeer, everything that pertains to the biography of the species-should be noterl down, and little or nothing trusted to mere memory where exact data are so essential. Many insects, particularly dragon-flies, have brillant coloring when fresh from the pupa, which is largely lost after- 
wark. The time of laying and hatehing of egges, the mumber from at

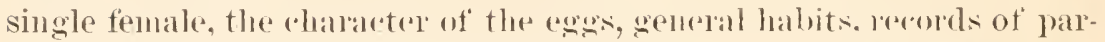
asites and their node of attack-all shombl be entered as observed. A great many specios have the most enroms life historios. which can wot be ascertained except by continued and persevering observation. not only in the vivarimn or insectary but in the field. It is alnost impossible to follow, moler artificial conditions, the full lite cycle of many species like the Aphirlide, or the Gall-flies, etc., which involve alternation of generations, dimorphism, heteromorphism, miglation fiom one. plant to another, and rarious other curions departures from the normal mode of development, without careful field study and experiment. These studies are possible only to those who are able to trecuent the same localities thronghont the whole year, and can hardly be carried on by the traveling natmalist or collector.

\section{INSTRECTIONS FOR COLLECTING AND PRESERTING ARACHNIES AND MYRIAPODS.}

The foregoing portions of this manual have dealt almost exelusirely with the subject of the securing and preservation of Hexapods, but it is deemed advisable to include brief instuctions for the collection and care of the near allies of the true insect, Spiders and Mrriapords. the study of which will in most eases be associated with that of Hexapods.

\section{DIRECTIONS FOR COLLECTING SPIDERS.}

Apporatus.-Many of the directions and methods given in the foregoing pages for the collection of Hexapods apply also to the animals named above. Little apparatus is necessary in the collection of spiders and other Alachnids. The essentials are rials containing alcohol, an insect net, a sieve, and forceps. Narrow vials without necks are best for collecting purposes, as the corks can be more fuickly inserterl. They should be of different sizes, from 1 dram to 4 or 6 drams, and the alcolol used should be at least 50 per cent strong and in some rases it is advisable to mse it at a strength of 70 or 80 per cont. The nut may be of the same construction as that userl to collect insects and is usol in the same way. Some arachmologists, howerer, wse a net of a somewhat different make, which is much stronger. 'The iron ring is heavier and larger than in the ase of the insect net, resembling in this lespert the ring of the Jeyrolle net. The hag is short and the hamdle is fastenerl to both sides of the ring. 'This net is med for beating the leaves of trees, bushes, and grass. Dr. Marx mses a net which is abrarly

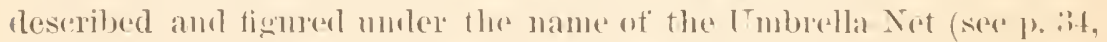

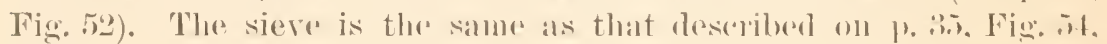

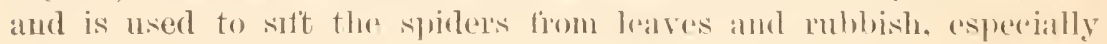


during winter. A mass of leaves and other material is thrown into the sieve and then shaken. the spiders falling throngh on a piece of white cloth, which is spread moler the sieve on the gromul. llany hibernating species "an he readily secured in this minnur. A forceps similar to that described for the eollectingof hexaporls should be used to anjoture or pick np specimens, for it handled with the fingers they are apt to be rushed, esperially the smaller forms. As soon ats

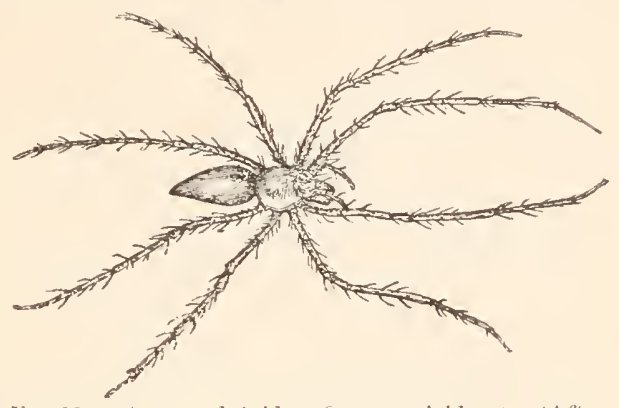

Fig. 129.-A grouml spider (oxyopes viriclans). (After Comstork.) the collecting is tinished or the vial is filled a babel shonld be plated in this last indleating place and date of collection. Egga sales and cocoons should be collected in pill boxes and properly labeled, and if possible the adnlts should be reared. Both sexes shonld be collerted and descriptive notes or drawings made of the webs as found in nature.

Lime and Locality for Collectiny. - The best time to collect spirler's is in the early fall, during the months of Septenber and October. The great majority of the species are then mature. Many forms, however, ocenr in the arlult state in late spring and early smmer. Numerous species may also be collected during winter, some of these hibernating under stones, the bark of dead trees, ete., and other's, more particularly the small forms, under dead leaves and rubbish on the ground in woods. Other species whieh have hibernated may be found about the earliest flowers in spring. No particnlar localities can be indicated for the collection of spiders, since they occur in all sorts of places, in wooded or open regions and also in and about dwellings. Many Lyeoside are

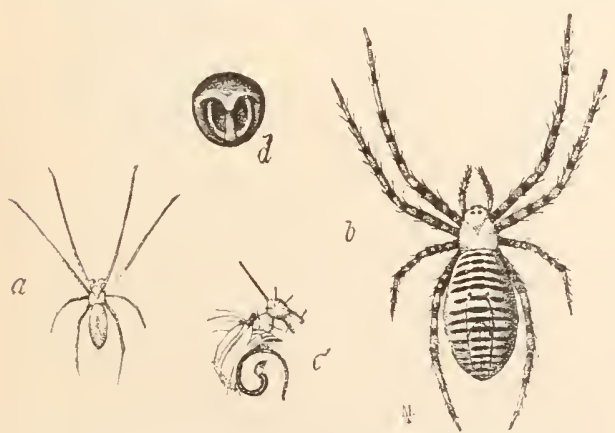

F1c. 130.-An orb-weaver (Argiope argyraspides Walck): a. male; $b$, female; $c$ and $d$, enlarged parts. found in dry and rocky situations and quite a number in open fields. Thomisidie may be found on flowers. The Therididie affer tshad y places, and many Epeiride will be found in similar situations. The Attidie love the sim and are found very actively engaged in hunting insects on plants and dead leaves. Mauy species of this family will be found in cases nuller

loose bark in winter. Evergreen trees are also quite good collecting grounds for Attille. The Drasside are ground spiders and are mostly noctumal, hiding during the day moler leaves and stones; a few forms, 
however, disport in the hottest smshine. Some genera are timnd most frequently near water or in damp plares, ats I bolomedes and Tetragnatha: other's in sandy places, as Miearia, Targalia.

COLLECTING O'THER ARACHNIDS: MITES, TIClís, SCORPIONA. F'T

Other Arachnids-as mites, ticks, scorpions, dadty longlegs or harvest-men-may be eollected in the same way as spiflers.

The Phalangida (Harvest-men) somewhat resemble spiders, and an' at once recognized by their extrenely long legs. 'They occur about houses,

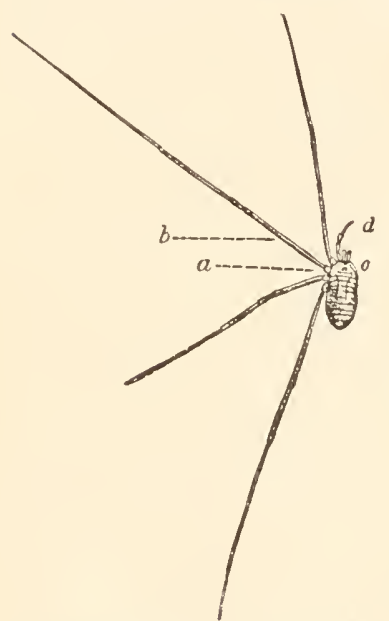

FIG. 131.-A llarvest-man (Phalan. gium ventrieusum).-From Pack. ard. especially in shady plares, mider the eaves, ete., and in the woods and fields. They are carnivorous and feed on small inserts, esper.ially Aphides. They should be presised a little when waptured to extrule the genital appraratus, if possible, and are best collected in the early fall.

The Plorynida are very pecoliar looking animals, the anterior legs being very long and slender and the maxillary palpi very large. The genus Thelyphomus is not nurommon $\mathrm{m}$ the South, and is known by its oblong body, ending nsmally with al long, slender. manyjointed filament, from which they are called Whip-tailed scorpions. T. giganteus is the common species. They occur in moist situations, and are carniv. orous, feeding on insects and small animals.

The false seorpions, Chermetidie, may at mee be recognized by their large maxillary palpi, resembling the maxillie of the true sompron. They are small insects, rarely exceeding a cuarter of an inch in length, and are found m dark shady places and feed mon mites, Psom, and other small insects. A common spercies is represented at figure 132.

The true seorpions, seorpionida, are well-

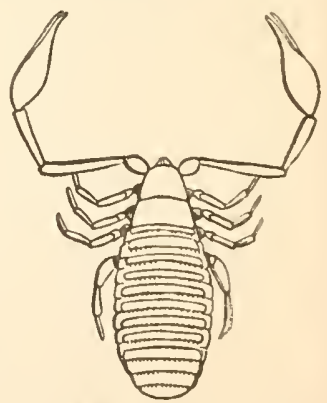

Fig. 132.- False S.orpion (Che. lifir cancroites L.).-Wirom lackarrl.

known forms, and are easily reongnized by theil harge. powertul, torceps-bike maxillar, and the long slenter tail continnoms with the thorax and ending with a sting, which is, in most eases, quite poisonoms. They

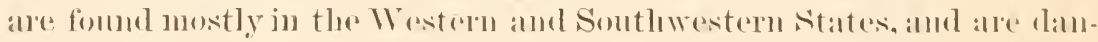
gerous in proportion to their size. The poisonous nature of the sting of these aninals is, howerere, generally overated, and the wounds. even of the larger speeries, are rarely fittal.

The Aearina or true mites are the lowest representatives of the Arachnidat and indude many genera and sperobs differing very widely 
in habit and chanaters. Some of then are mere sacs. on which the moutl parts or other organs are searcely discernible. In general they resemble spidirs. The yomng, howerer, when they leave the egg, almost invariably have but three pairs of feet, resembling in this respect the Hexapods. The fourth pair is added in the later stages. They are parasitic on insects and otler animals, and some of them are vegetable feeders or live in decaring regetable and animal matter.

A very interesting group is comprised in the family Plytoptidæe or gall-making mites which occur on the leaves of varions trees and shrubs and produce curioms galls or abnormal growths. These mites are elongate in form, have rudimentary

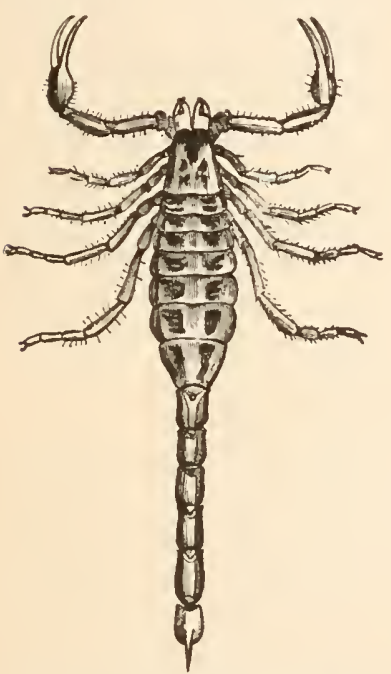

Fig. 133.-A true Scorjuon (Buthus carolinianus).-From Packard. month-parts and but four legis. A com11101 form. Phytoptus quadri-

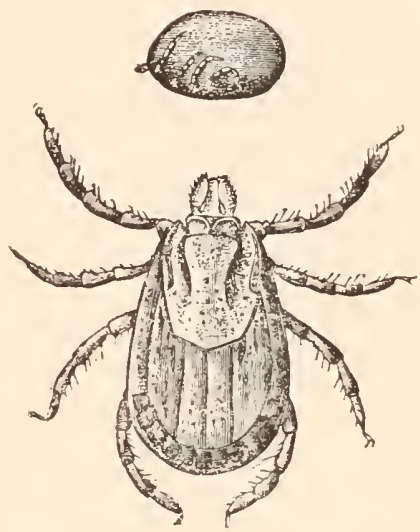

FIG. 134.-The Cattle-tick. (dfter Packard.) pes, produces a gall on the leaves of the soft maple. The galls of all species should be rolleeted and pimmed and also preserved in alcohol, and specimens of the mites should be mounted in balsam.

The members of the gemus Sarcoptes are very mimute and are the alctire somre of the itch in the lower animals and man. Another common genus is Tyroglyphus, which includes the common cheese mite, $T$. siro. Other species of this gemus also sometimes oceur in enormous numbers in grocers's supplies. Still others are parasitic on insects, and one species, T. phylloxerce Riley, is very beneficial, since, as its name indicates, it feeds on the Pliylloxera of the grapevine.

The Ixodida comprise the ticks which attach tliemselves to eattle, hogs, and man, and are not at all uncommon objects. These insects can be found on the animals they infest, and distinct species will be fonud to occur on most wild mammais. The common Cattle tick Boophilus bocis Riley, is represented at Fig. 134.

The family Orobatidie includes a number of small terrestrial nites, which oceur on the moss on trees and stones. Some species are known to feed on the eggs of insects, and the one shown in the accompanying 


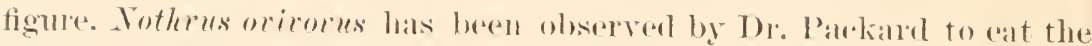
egess of the ('ankire ITorm.

The members of the fimnily Camasida are palasitiv mom animals,

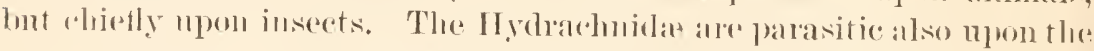

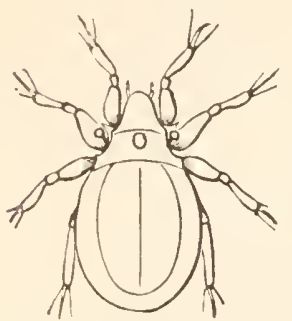

FIG. 135.-Nothrus ovivores

Packard. apratic insects, and also affect fish or mussels or oceril on fresh-water plants.

Onc of the most important families of mites is the 'Trombidiidiar which inchudes a large number of species, some of which orem in immens. numbers. Most of them are vegratule fixders. Int some species feed on the eggs of insects.

The gemus Trombirlinm includes a number of the Red Mites whieh feed on insects in all their stages. The Locoust Mite, Trombirlium locusturum Riley, is one ut the most interesting as well as one of the most important of our lorust emenies, and will serve to illustrate the habits of the gromp. It difters so much in infancy and maturity that it has heen referred to different genera and is known muler different names. The matme form lives on the ground and freds on all sorts of animal or decomposing vegetable mattre, and wherever the gromed is filled with locust eggs these afford an abundanne of foul and the mites Homish and multiply rapilly. In the spoing the female lays 300 or 400

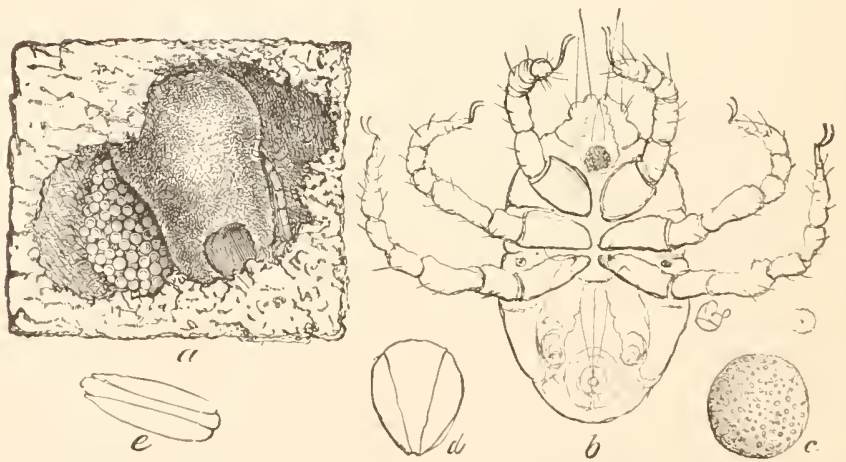

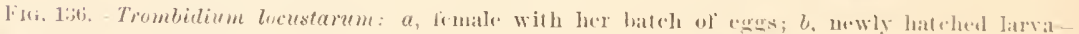
natmal size indieated by the dot within the cirele; $c$, egg; $d e$, vacated eger-shells,

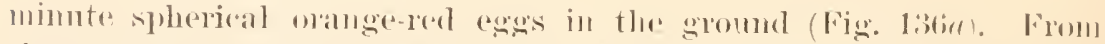

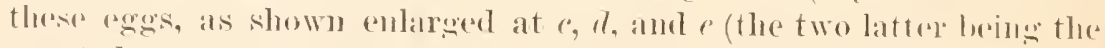

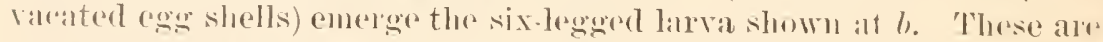
mere spereks and crawl actively abont, fastening themsolves to the lorests mostly at the base of the wings or along the mpere veins.

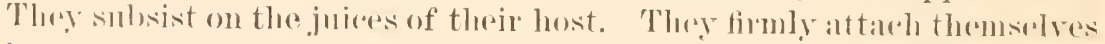

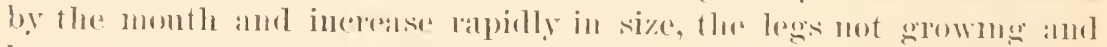

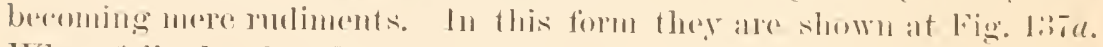

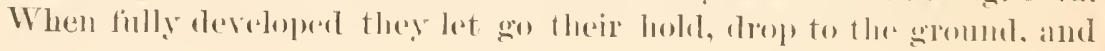


crawl nunder the shelter afforded by holes in the earth or under sticks. Here. in the course of two or three weeks, they transform within the

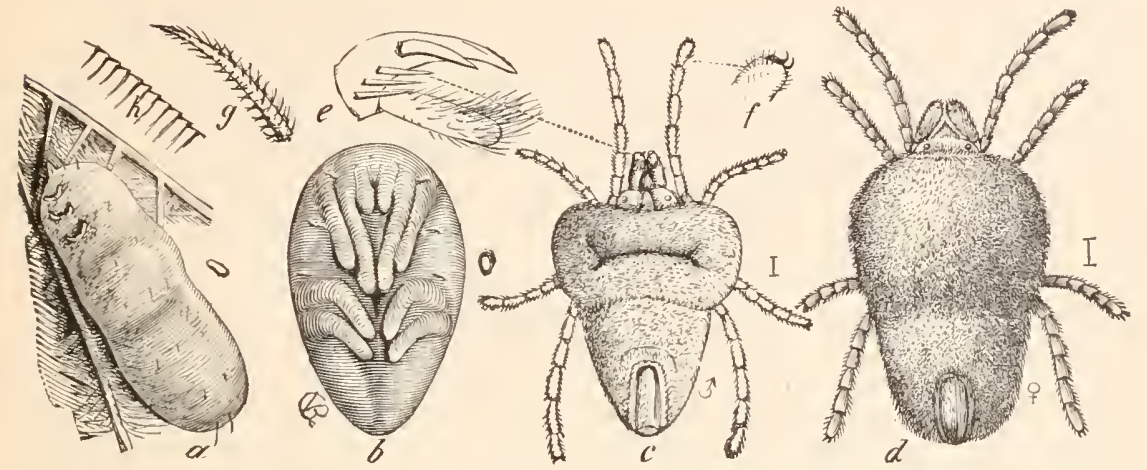

FIg. 137.-Trombidium locustarum , a, mature larta when about to leave the wing of a locust; $b$, pupa; $c$, male alult when just from the pupa; $d$, female-the natural sizes inclicated to the right; $e$. palpal claw and thumb; $f$, pedal claw: $g$. one of the barbed hairs; $h$, the striations on the larral skin.

larval skin to the pupal stage shown at $b$, and eventually brak through the old larval skin and escape in the form shown at $c$ and $d$. This mature form passes the winter in the gromul and is active wheneres the temperature is a few degrees above the freezing point. A larger species $T$. gigunteum Riley, ak: attacks locusts, while a third species attacks the common House-fly. This was formerly known in the larra state only and was referred to the genus Astoma, to which also the larval form of Trombidinm was referred. I have described the adult together with the larva and pujar as Trombinium muscurnem. An allied mite, Hydrachne belustoma, attacks the large aquativ water bug, Belostoma, and has a mode of development precisely similar to that of Trombidium.

To this family also belong the common greenhouse mite, Tetranychus telarins, and also the Bryobia mite, B. protensis, which of late years has attracted very considerable attention by its appearance in immense numbers abont dwellings, comning from the adjoining fields of ciover or grass. Generically allied to the greenholuse mite is the Six-spotted Mite

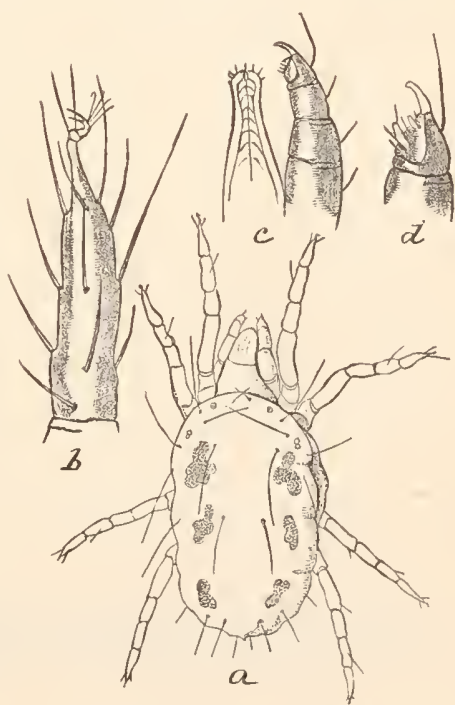

FIG. 138. - The Six-spotted Mlite of the Orange (Tetranychus G-maculatus): $\boldsymbol{a}$, from above-enlarged;, - tarsus ; $c$, ros. trum and palpus-still more enlarget; d, tip of palpus-still more enlarged. of the Orange (T. 6-maculatus Riley), which is shown in the accompanying figure. 
Spiders and mites thus collected may be transfered to alcohol. Dr. Marx, who has had a very comsiderable experience in the preservation of spiders, recommends the use of the following mixture: filyerein

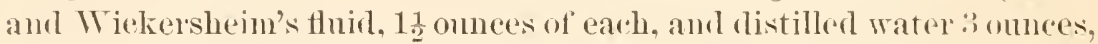
the whole to be shaken and thommghly mixed and arded to 30 onnees of 95 per rent alcohol. Aleohol which has previously been unid for pre. serving spiders, and which has therefore dissolved some of the tatty matters from the specimens, he prefers to pure alcohol, using with this, however, somewhat less of the distillerl water. The lignid thus romposed answers all demands and keeps the specimens Hexible and preserves their coloring. Shonld the stopper become loose and the linwid evaporate, there is always sufficient liquicl, water or glycerinc, left in the vial to keep the specimens from drying and thus save them from destruction. Dr. Marx also prefers to use rork stoppers rather than the lubber stoppers recommended for other alcoholic material. His ohjec. tion to the rubber stopper is that, in a collection in which the specimens are often used and the stoppers are frequently removed, he finds that small particles of the rubber stopper come off and settle mpon the sprecimens as a white dust, which it is difficult to remove. This objection applies only to a poor quality of rubber, and in all other respects the rubber is much to be proferred. The color's of spirlers are apt to firle somewhat if exposer to light, and the collection should therefore be kept in closed boxes or in the dark.

\section{COLLECTING IIYIAPODA.}

Centipedes and Milliperles are collecterl in the same manner as spiders. They live in damp places, muler sticks and stomes, and in decaying vegetation. They should be preserved in alcohol, and on account of their usually strong chitinous eorering, precautions as to the strength of the alcohol are less necessary here than with softerbodied specinens.

The members of this subclass comprise a mmber of well-marlierl groups. The Inlidat are cylindrical inserts and orem in moist plarers. as do most of the representatives of this subclass. A common fom is representerl in the acrompanning figure. The Chilinpolite romprise the flattrined forms having manyjointed antemua and but a single pair of limbs to eachesegenent of Fis. 139.-A Milliped (Cambula annulatu). the body. and are the forms to which the name centipede may properly be appliod. They are preditceous in habit, live largely on living animal matter, and anrerer quick in their movements. Some forms ale poismonts, having poison glands at the base of the first pair of les's, hut the majority of the speciess are 
entirely harmless. I number of common species belong to the genus Geophilus and ocemr under stones and logs. The genus Scolopendra includes some of the larger species of the order. The largest known speeies, S. yiganten, oecurs in the East Indies and attains a length of from 9 inches to more than a foot. Several speeies fornd within the limits of the Lnited States attain a length of 5 inches or more. The family Cermatiidie includes the very common species Cermutia forceps, which, while abundant in the Sonth and West, oecurs somewhat more rarely in the Nortl. It is commonly found in moist situations, in honses or conservatories, and on aceount of its long legs and agile movements frequently creates considerable consternation. It is, however, an entirely harmless and very beneficial speeies, since it feeds on various household pests, including flies, roaches, ete.

\section{TEXT BOOKS-ENTOMOLOGICAL WORKS.}

Bulletin No. 19 of the Division of Entomology, U. S. Department of A grienlture, contains an enmeration of thes pullished synoposes, catalogues, and lists of North American inserts, together with other information intended to assist the stndent of American entomology. This can be had upon application, and I would refer the student to it for sperifie information as to synopses, catalogmes, and lists. I have deemed it advisable, however, to inelude here an enmmeration of the more nseful works of a general character; a list of the entomologieal periodicals, both home and foreign; and the entomological works published by the different departments of the Government, with some information as to how and of whom they ean be obtained. Many of these publieations are no longer to be had exeept as they may he pieked up throngl bookdealers; but the titles even of those which are ont of print will be useful to the student as a ginde to what he should find in every gond library. Rerunests for this kind of information are constantly received at the Department of A griculture and at the National Museum. The most useful general works are given tirst, and, while a great many others in foreign languages might be cited, I would strongly arl vise the beginner in America to confine himself to these, ant especially to reat Harris's Inseets Injurious to Vegetation, Kirby \& Spence's Introduction, and Westrood's Introduction. This last, thongh published over lalf a century ago, is still one of the most useful entomologieal works in the English language. While these Introductions will be of great service in arranging and classifying material and in giving a knowledge of the relationships of speeies, there is no better text-book than the great book of nature, which is always ready to unfold its tuuths to every earnest inquirer. In field and wood alone can lie become familiar with the insects in all their wondrous life habits, instincts, and intelligence. There alone will he receive the fullest inspiration and pleasure in his work or find the highest reward for his etforts. 
COMPREHENSIVE WORKS MOST USEFIL FOR THF STIDY OF NORTH AMERICAN INSECTS.

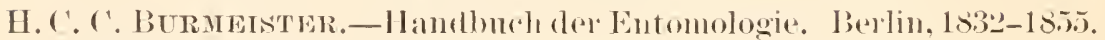
¿̀ vols.

MANeAL of Entomology.-A tramslation of the above, by W. E. shomekard. London, $18 ; 36$.

J. O. WESTwOOD.-An introduction to the nodern classification of insects, foumled on the matural habits and corresponding organization of the different families. "2 vols. Lomelon, 1s39-40.

THomas SAY.-Complete witings on the Entomologr of North Amerjua; alited by John L. I. Conte. New York, 1859.

H. A. HAGEN.-Biblinthera Entomologica. Die Litteratur iiber das ganze Gebiet der Entomologie bis zmm Jalne 1862. Leipzig., 1862.

A. S. I'ACKARD.-Cinide to the Study of Insects. ITemry Holt \& Co., Plibladelphia and New York. (First exlition, Salem, 1869.)

Entomology for Beginners. Hemy Holt \& Co., New York, 1885.

The STANDARD NATrRal History.-Eilited by John Sterling Kingsley. S. E. C'assino \& Co., Boston, 1851-'8j.

Volume I1 contains the insects, which are treater hy the following anthors: Hymenopterr. J. 11. Comstock aud L. O. Howard; Coleoptera, George Dimmock; Lepidopteru, II'y Edwards anıl ('. H. Fernalı; Itiptera, S. W. Wilhiston; Orthoptera, C. V. Liles; Hemiptera, P. R. Thler: Vemoptera. A.s. Packirrl; Arachida, J. Il. Emerton.

J. Н. Constock.-An Introrluetion to Entomology. Published by the author. Ithara, N. Y. ¿ parts. Part I, 1885.

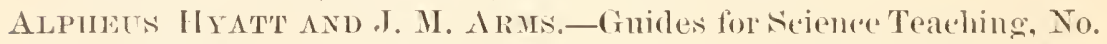
II. Insecta. Bos. Sor. Nat. Hist. D. C. Heath N Co.. Boston.1890.

(IENERAL WOIKS ON CLASSIFICATION.

HYMENOHTERA.

E. T. CREsson.-Synopsis of the Families and Genera of the Iymenoptera of Amerion, not of Mexico, togethere with a Catalogue of the

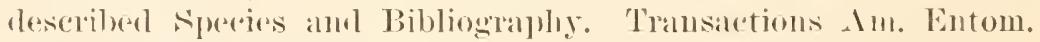

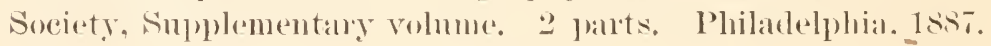

CUIEOT'TERA.

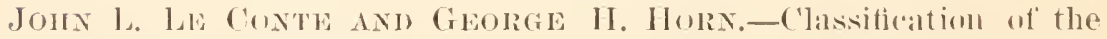

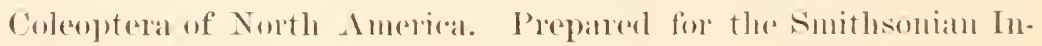
stitution. Washington, Nulutsonian hostitution, Iss.s.

This is the most recent and the only complete classification of North Ameri-

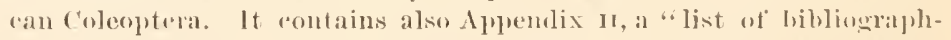
ical references 10 memoirs, in which more or less complete symepses of the families, gemeral, and specius of the ("eleoptera of the linterl states have bern published."

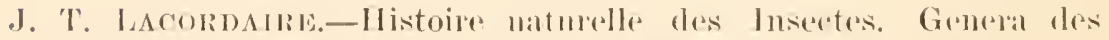

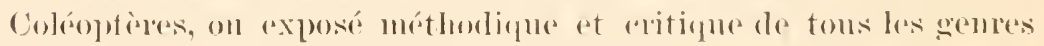

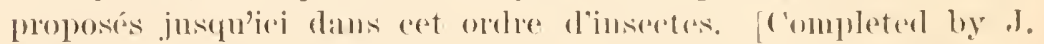
Chapmis.] P'aris, France, 1sit-1sti. 12̈ vols. and i vol. plates. 
* Willay Le barox.-Ontlines of Eutomology, published in comnection with the anthor's Ammal lieports mpon injurioms insects. Pant first. Ineluding the Order of Coleoptera. Fomth Ammal Report on the Noxions and Beneficial Insects of the State of Illinois. Sel. Edit. Springtield, 187t.

LEPIUOPTERA.

G. A. IV. HERRICH-SCHAEFFER.-Sammlmug nener oder wenig bekamter ausseremopaischer Sehmetterlinge. Vol. I. Regensbura, 1850:s; Vol. II, Pt. 1, 1s69.

Contains a classification of the Lepidoptera, which forms the basis of our present arrangement.

JoHs G. MonRIs.-Synopsis of the deseribed Lepidoptera of North America. Part I. Diurnal and Crepuscular Lepidoptera. Wash. ington, Snithsonian Institution, 1812.

Compiled descriptions of the North American Lepidoptera, from the Rhopalocera to the Bombycislix.

H. STrEckER.-Lepidoptera, Rhopaloreres et Heteroreres, indigenons and exotic: with descriptions and colored illustrations. Reading, Pa., 187:-7\%.

Fifteen parts of this work have been published containing figmes and ileserjptions of many North American species.

Jonn B. Sunth.-An Introduction to a Classification of the North Ameriean Lepidoptera. <Bull. Brookl. Ent. Soc., Vol. vis, 1ss4, pl. $70-74$ and $81-83$.

A synopsis of the families of Lepidoptera based on Herrich-Tehaeffer's classitication.

Symopsis of the Genera of the North American lihopalorera. <Bull. Brook1. Ent. Soc., Tol. vi, 1883, 1). 37-45.

E. Dotbled I AND W. C. Hewitson.-The genera of dimmal Lepidoptera, comprising their generic characters, a notice of their transformations, and a catalogne of the species of each genins; illustrated, with 86 colored plates from thawings by W. C. Hewitson. ¿ vols., Loudon, 1s46-52.

This work was completed by Westwond after the death of Donbleday.

S. H. Scudder.-Butterflies: Their structures, changes, and life-histories, with special reference to Anerican forms. Being an application of the "Doctrine of descent" to the study of" Butterflies, with an appendix of practical instructions. 321 pp. and 201 text figs. New York, Henry Holt \& Co., 1881.

The Butterflies of the Eastern United States and Canarla with special reference to New England. 3 vols., Cambrirge, Mass., 1859; pp. 1958, plates 59. (Published by the anthor. Cost about $\$ 75$ for 3 vols.) 
G. H. Frexch.-The Buttertlies of the Easteln Uniter States. For the nse of elasses in Zoölog and private students. Philadelphia, lippincott \& Co., 1886.

Gives spnopses of the genera ind speries, and description of the speriw.

W. II. EDWARDs.-Buttertlies of North Ameriea. Boston, IIonghton, Mittlin \& Co.

Two volmues are completerl and the third is in course of publication.

HWMIPTEILA.

Herbert Osborn.-C']assitication of Hemiptera. < Entomologica Imer., V'ul. 1, 1855, p1). ¿1-27.

short characterization of the whole wroler, with tables of stmorilers and fimilies.

Pedienli and Mallophaga affereting Man and the Luwer Animals. Constituting Bnlletin So. 7 of the Division of Entomology, T. S. Department of Agriculture. Washington, 1891.

P. R. IHLER.-- List of Hemiptera of the region west of the Mississippi River, including those collected during the Hayden explorations of 1873. <Bull. U. S. Geolog. and Geogr. Survey of the Terr., Tol. I, 1875, pp. 267-36;1, Pl. хтx-хх1.

Report upon the insects collected by P. R. Uhler during the exploration of 1875, including monographs of the families Cynidie and Saldie, and the Hemiptera collectenl ly A. S. Packard, jr., M. D. <U. S. Geolog. and Geogr. Survey, Bulletiu, Tol. In, No. 2, 1877, pр. $355-475$.

Townend GLover.-Report of the Entomologist. <Report of the Commissioner of $A$ grienlture for the gear 1875, ju. 17-46.

A popular treatise on the Homoptera, with illustrations.

A. H. Hatiday.-An Epitome of the British genera in the Order Thysanoptera, with indications of a few of the specles. <Entomol. Mag., Vol. 111, 18:36, pp. 439-451.

\section{DIPTELA.}

H. LOEW AND C. R. ( STEN-SACKEN.-Monographs of the Diptera of North America. (Smithsonian Miscellaneons Colleetons.) + parts. Washington, Smithsonian Institıtion, 1Sti2-7:.

The severil monographs will be found emmexated mulep tlod respertive families.

H. Loew.-Diptera Anerieate septentrionalis indigena. z̈ parts. Berlin, 1861-72. (()riginally published in 10 centuria in the berliner Eutomol. Keitschlift.)

Deseriptions of 1,000 North American Diptera, hut without șuoptic arrangemint.

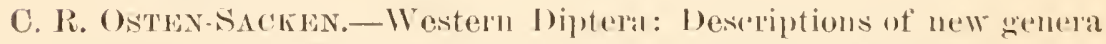
and speries of Diptera from the lowion west of the Mississippi and especially from Califorma. <Bull. U. S. Geolug. and Geogr. Survey of the Territories, Fol. III, 157., pl. 189-395. 
F. BrAuER,-Die Zweitligler des Kaiserlichen Museums zu Trien. 1-III. Wien, 1850-'s3.

Important contributions to the classification of the Diptera.

ORTHOPTERA.

HExRI DE SAUSSURE - Orthoptera nova Imericana (Diagnoses pra: liminares). Series I-III. <Rerne et Mag. de Zool., 1S59-'61.

Contains synoptical tables of species, besicles descriptions of unmerous North American Orthoptera.

SArtel H. SCUdDER.-Materials for a monograph of the North American Orthoptera. <Boston . Journal of Nat. Hist., Tol. vir, 1862, 1). $409-480$.

Contains sprnoptical tables and a review of the strstem used for classification.

-Remarks upon the arrangement of the families of Orthoptera.

<Proc. Boston Soc. Nat. Hist., Vol. xin, 1S68-'69; also separate uncler the title: Entomological Notes, Vol. II, pp. 7-14.

-Synoptical tables for determining North American insects. Orthoptera. <Psyche, Vol. I, 1876, 11). 169-171.

Syuopsis of families; also list of useful works in the study of North Ameriean Orthoptera.

\section{NELROPTERA.}

Heridan Hagen.-Synopsis of the Neuroptera of North America, with a list of the South American species. Smithsonian Miscellaneous C'ollections, Washington, 1861.

-Synopsis of the Odonata of America. <Proc. Boston Soc. Nat. Hist., Tol. xvin, 1575, pp. 20-96.

Sir John LubBock.-Monngraph of the Collembola and Thysamura. London, Ray Societs, 1873.

The introduction gives the full bibliography up to date.

MYRIAPOINA.

THomas SAY.-Deseriptions of the Myriapoda of the United States. <Jomrn. Ac. Nat. Sc. Phil., Vol. II, 15:1, 11. 10:-114; Say's Entom. Writings, ed. Le Conte, Tol. II, Pp. 24-32.

This is the first paper of importance on the North American Myriapodil.

Geurge Newpor't.-Monograph of the class Myriapoda, Order Chilopoda. <Trans. Linnean Soc. of London, Vol. XIx, 1845, 1). ¿65302 and $349-439$.

Horatro C. Wood, Jr.-On the Chilopoda of North America, with Catalogue of all the specimens in the collection of the Smithsonian Institution. <.Joum. Ac. Nat. Sc. Phil., New Ser., Vol. v, 1863, 1). T-42.

The Myriapoda of North America. <Trans. Amer. Philos Soc., Tol. xIII, 1565, pp. 137-248, 3 pl.

This is the first and only monograph of the Myriapoda publishet in this country. 
Robert LAtzel.-Die Myriapoden der Oesterreichisch-Lnearis.hen Monardhie. Erste IIällte: Die Chilopoden, Wien, 18so. Zweite Hiilfte: Die Symplyylen, Panropoden mol Diplopoden, Wien, 1sst.

The most recent eomprehensive work on this order, and veryimportant fiom a classificatory standpoint.

Lucien M. Underwood.-The North American Myriapoda. < Eutomol. Amer., Vol. I, 1885, P1. 141-151.

A complote bibliographical review of the subject, with tables of fanilies and genera.

ALACHNIDA.

N. M. Hentz.-Descriptions and figures of the Araneirles of the Tnited

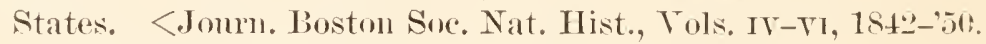

These papers form the basis of the study of American arachnology. Numerous species are clescribed, but not in synoptic form.

T. Thorell, On Emoprean Spiders. Part I. Review of the Enropean genera of Spiders. Upsala, 1869-70.

N. M. Hentz.-Aranese Ameriese septentrionalis. The Spider's of the United States. Edited by J. H. Eunertom and E. Burgess. < *uc. easional Papers" of the Boston Society of Xatmral IIistory. 1sits.

A reprint of Hentz's papers on North American spiclers.

Graf Eugen Kexserlixg,-Amerikanische Spinnen ans den Familien Pholeoidre, Scytodoidae und Drsideroide. < Verh. k. k. zool. bot. Ges. in Wien, Vol. xxvi1, 1877, 1p. 205-234.

Nene Spinnen ans Anerika. (Six parts.) <Verh. k. k. \%ow.-bot. Ges. in Wien, Vols. xxix-xxitv, 1879-'st.

E. Simon.-Les Arachides de France. Paris, Tols. I-T, 18itzist.

These two works represent the most recent systems of classification, and are therefore of great general value, although they deal only with the European fiuna.

Ludien M. Underwood.-The Progress of Arachnology in America. <Amer. Natur., Vol, xxi, 1887, pp. 6163-97.5.

A very useful review of the bibliography, with synoptir tahlo of the families of the Aramese.

\section{AMERICAN PERIODICALA.}

The Americax Naturalist. A monthly jommal devoted to the natural sciences in their widest semse (ㅂt volmmes publisherl mp to date. Now published at Philadelphia).

*ANNAL OF THE LYCETM OF NATTRAL HISTORY OF NEW YORK ( volumes, 1824-67. Continned since 1866 as Ammals of the New York Academy of Sciencess).

* Butlatid of the Brooklyo lintoyological socilety (a volmues. 187s-8.). Contimed as Entomologica Americana).

BUlletin OF THE BIFFALO SOCLET OF NATURAL HISTORY (4 volmomes completed; 185.1 to $18.8 \%$.

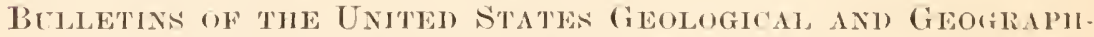

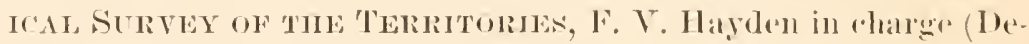
partment of the Interior; 1875 to L87!. 
Bulletins of tife United States Geological Survei, .J. M. Powell, director; beginning with 1883.

Bulletins of the United States National Museum (Department of the Interior: beginning with 1875$)$.

The Canadian Entomologist. (Published by the Entomological Society of Ontario; '2: volnmes issued up to the end of 18!no. Published at London, Ontario.)

* Entonologica Americana. (Published by the Brooklyn Entomological Society at Brooklyn, N. Y. 1855 to 1890.)

Extoyological News [and Proceedings of the Entomological section of the Academy of Natural Sciences] (Vol. I issmed in 1s90. Pub. lished at Pliladehphia).

Journal of tile Acadeir of Natural Seiences of PillabelPHIA (commencing with 1817).

Memoirs of tile Boston Society of Natural History (eommencing with 1566).

* Norti Ainerican Entonologist. (Published by the Buffialo society of Natural Sciences, 1 volume, Buffalo, N. Y. 187!-'80.)

* Papilio. Devoted exclusively to Lepidoptera. Organ of thr New York Eutomological Club (4 volumes, 1S81-'st).

Psyche. Organ of the Cambridge Entonological Club (5 volumes issued up to date. Published at Cambridge, Mass. Publication begun in 187t).

Proceedings of The Aradeiry of Natural Sctences of PHilaDELPIIA (beginning with 1841).

Proceedings of THE AJERICAN P'IILOSOPHICAL SOCIETY OF I'HILADELPHIA (beginning with 1860 ).

Procendigs of the Boston Society of Natural Histori (commencing with 18t1).

* Proceedings of tie ENTohological Society of Pilladelphia (6 volumes, 1861-'67).

Proceedings of the Entonological. Society of Washington (" volmmes, beginning with 1SSt).

Proceedings of the United States National Museux (Departunent of the Interior; beginning with 187s).

Reports of the United States Geological and Geographical Survey nF THE Territories (Department of the Interior: beginning with 1867).

Syithonian Miscellaneous Collections (Smithsonian Institution, Washington, 1). C.; beginning 1S62).

Transactions of the Academy of Science of St. Louis ( $t$ rolumes hitherto published).

Transactions of the American Entomological Societr and Proceedings of the Eutomological Section of the Academy of Natural Sciences (beginning with 1868; published at Philadelphia). 


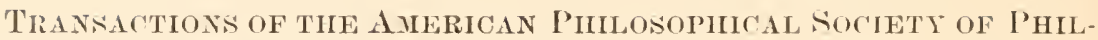
ADELPIIA ("Zd series beginning with 1818).

Papers on entomology are also published oceasionally in other Ameriean periodicals, among which the following might be mentioned:

Joural of the Elisila Mitrinell Srientific Societr. Chapel HIIl, N. C.

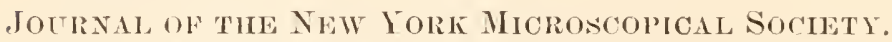

Nateraliste Canadies. Edited by Abbé Provancher, Cap, Ronge, Queluer.

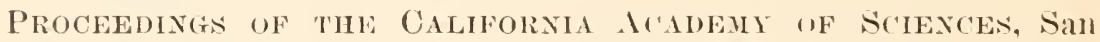
Franciseo, Cal.

FOREIGN I'ERIODICALS.

Axyles de la Sochété entonologique de Belgigé. Publination begun in 1857. Brussels.

Annales de la Sochété extomologique de France. Publication begun in 1832. Paris.

* Berliner fatonologinche heitscirrift. 18 volumes. Berlin, $15.7-1874$.

Succeded by the Deutsche Entomologische Zeitung.

Bulletin de la Sochété extonologigé de Fraxce.

Butletin de la Société extoyolugique suisse. (See Mitheil d. Schweiz. Entom. Gesell.)

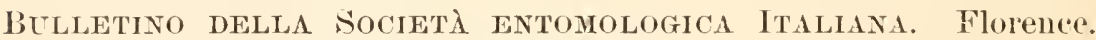
(Publication commenced in 1869.)

Deutacin Entonologisehe Zeitschrift. Pnblished by the Entomological Society of Berlin. (Publication begun in 1875.)

Entoyologische Naciriciten. (Now edited by J)r. F. Karseh. Berlin. Publication commenced in 15\%.).

ENTOMOLOGIN THOSKRFT, PA FöRANSTALTANDE AF ENTOMOLOGISKA Förentygen I STOCKHOLM. (Commenced with 1s80.)

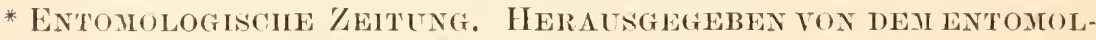
ogischen Verin zu S'TetTin. 36 volmmes. Stettin. 1840-7.;.

ENTOMOLOGISKE MLDDELELSER UDGIVNE OF FNTOMOLOGISK FORE. Nisg. Edited by Fr. Meinert, Copenhagen (begimning with 1857).

THe Extomologist. A popular monthly jumal of British entomology. Vol. 1, 1840-4:2. (Publication resumed in 1stit. Lomelon.)

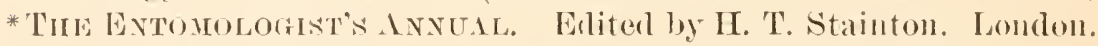

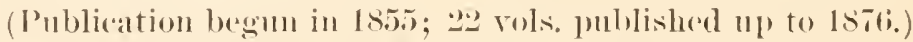

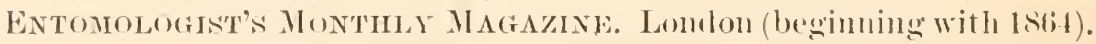
Horae . . Variis sermomibus rosial nsitatis. Sordetas Entomologiea Rossica. (Publiontion legenu in 1sti1.)

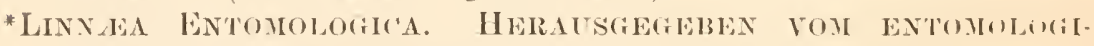

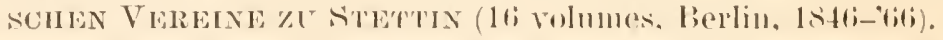


MITTHELUTGeN DER SCHWEIZERISCHEN ENTOMOLOGISCHEN GesELLnCHaft. Bulletin de la Société entomologique suisse. (Publiaation begun at Schaffhausen, Switz., in 1862. Afterward published at Geneva.)

Revie D'Entonologie. (Published by the Société Française d'Entomologie, Caën, France. Publication begnn in 1852.)

Timpschrift yoor ENTomologie. Nederlandsche ENtoyoloGiscie Vereeniging, Leiden, Holland (beginning with 1857. Published by the Dutch Entomologieal Soeiety).

Traxictions of the Extomological Society of London. (Begun in 1834.)

*Wiener entonologische Monatsscirift (8 volumes, Vienna, $1557-$ - $^{2}(1)$.

Wiener extoulologische Zeitung. Vienna. (Commenced 18S2.)

*Zeitschrift für die Extomologie. Edited by E. F. Germar (5 volumes. Leipzig, 1839-'44).

Zeitschrift FÜr ExtoMologie. Verein für schlesische Insechter-Kunde zU Breslau. (Publication begun at Breslau in $15+7)$.

ZEITSCHRIFT FÜR WISSENSCHAFTLICHE ZOOLOGIE. Leipzig. (Begun in 1815).

A large number of other periodicals devoted to entomology have been issued, prineipally in Europe, but after continuing for a year or more their publication has been abandoned, and they are not included here. Important entomological papers have also been published in many serials devoted to zoölogy or the natural seiences generally. Among them may be mentioned the following:

Annals and Magazine of Natural History. London (beginning with 1838).

Archiv für Naturgeschichte. Berlin (beginning with 1835).

Ofversigt af Kongl. Svenska Vetenskaps ACademiens Förhand.

Lingar (beginning with 1844. Published at Stockholm).

Proceedings of the Royal Swedish Acatemy of Sciences.

Proceedings of THE Zoölogical Society of London.

Revue et ilagasin de zoologie pure et appliquée. Paris (beginning with 1839).

SITZUNGSBERICHTE DER ILATIEMATISCH-NATURWISSENSCHAFTLIChen Classe der Kaiserlichen ACAdeme der WissenSCMAFTEN ZU WIEN (beginning with 1848).

Transictions of the Linnean Society of London (beginuing with $1791)$.

Transactions axd Proceedings of the New Zealand Institute. Wellington, New Zealaud.

VERHANDLU NGEN DER ZOOLOGISCH-BOTANISCHEN GESELLSCHAFT IN WIEx (beginning with 1852).

* Publication discontinued. 
LIST OF TIORE TSEFLL WORKS ON HCONOMIO FNTOMIOLOCY.

T. W. Harris, Insects Injurions to Vegetation. (Flint odition.) New York, Orange Juld Co. \$4 or \$ै. (First erlition, Cambridge, 1st1.) † Asu Fitci, Reports of the State Entomologist of New York. 1-xiv, Albany, 185.5-70. (For' a full alerount of these, see Finst Annual Report, by .J. A. Lintuer, State Entomologist of New York, lly. $294-2976$.

* The Practical Entomologist. Yols. I and II. Published by the Ento. mological Society of Philadelphia, 186ij-67.

* The American Entomologist, edited by B. D. Walsh and C. V. Riley. Vol. I. St. Louis, Mo., 1868. (Out of print.)

* The Ameriean Entomologist and Botanist, edited by C. V. Riley and Dr. George Vasey. Vol. II. St. Lonis, Mo., 1870.

* The American Entomologist, edited by C. V. Riley. Vol. III. See. ond series, Vol. I.] New York, Hub Publishing Co., 1880.

† B. D. Walsi, Annual Report on the Noxious Insects of the State of Illinois. Chicago, Prairie Farmer Co., 1stis.

$\dagger$ C. T. Riler, Reports of the State Entomologist of Missouri. I-IX, Jefferson City, 1869-'77.

$\dagger$ Willinir Le Baron, Reports of the State Entomologist of Illinois. I-IV, Springfield, 1s71-'74.

tCrrus Tromas, Reports of the State Entomologist of Illinois. I-vi, Springfield, 1876-'s1.

J. A. Lintrer, Reports of the State Entomologist of New York. Allany (beginning with 1882).

S. A. Forzbs, Reports of the State Entomologist of Illinois. Springfield (beginning with 1883).

Miscellaneons Essays on Economic Entomology. Springtield, III., 1886. (Pnblished instear of Ammal Report.)

MARY Treat, Injurions Insects of the Farm and Garden. New York, Orange Judd Co., 1882. (A small work compiled from Riley's reports.)

Wrilliair Saunders, Insects Injurious to Fruits. Philarlelphia, .J. B. Lippincott \& Co., 1883.

Matriew Conke, Injurions Insects of the Orehard, Vineyarl, ete. Sacramento, 1883. (Svo., pl). 47\%.)

P. J. Van Beneden, Anmal Pamastes and Messmates. New York, D. Appleton \& Co., 1876. International Scientific Series.

t Reports of the Eutomologists of the IT. S. Depitrtment of A grinulture, T. Glover (1863-1878), J. I. Comstorek (1s7!)-18so), and C.V. Riley (1878-1879), 1880 to date).

* Publication discontinued.

t Oat of print.

$\ddagger^{\prime}$ The annual reports of the Entomologist are contained in the corresponding ammal reports of the Department of Agrienlture. A linited anthor's edition, separately bound, and with table of contents and index, is publisherl each year. 
Bulletins of the Division of Entomology of the UT. S. Department of Igriculture, ('. V. Riley, Entomologist (1Ss:3 to rlate).

Reports and Bulletins of the U. S. Entomologieal Commission.

Jону Curtis, Farm Insects. London, Blarkie \& Son, 1860.

Ellaxor 1. Orumeron, Mamual of Injurious Inserets, and Methorts of Prevention, ete. London and Edinburglı, 1ssl. (A small work, (costing abont $\$ 1.50$.)

Reports of Observations of Injurions Insects and Common Farm Pests, with Methods of Prevention and Remedy. London. Simpkin, Marsluall, Hamilton, Kent \& Co., liniterl. (Fomteen reports issued up to 1891.)

J. H. KaltexbaCh.-Die Pflanzenfeinde aus der Classe der Iusekten. sro. Stuttgart, 1sit. (A nseful work for determining what insects infest plants in Europe.)

INsECT L1FE. Periodical Bulletin.-Devoted to the economy and the life-habits of insects, especially in their relations to agrienlture. Edited by C. V. Riley, entomologist, and L. O. Howard, first assistant, with the assistance of other members of the divisional force (Publication begun in 1888.)

E. L. Tascuenberg.-Praktische Insekten-Kunde. Parts I-V. Bremen, $187 !$.

Felice Franceschisi.-Gli Insetti Nocivi. Milan, 1891.

J. T. C. RatzeburG.-Die Waldverderbniss, ode: danernder Schade, relcher durch Insektenfrass, Schälen, Schlagen, und Verbeissen an lebenden Waldbïmmen entsteht. Two parts. Berlin, 1866-'6s.

ENTONOLOGICAL WORISS PUBLISHED BY THE UNITED STATES ENTOMOLOGICAL COMMISSION AND BY THE UNITED STATES DEPARTMENT OF AGRICULTURE.

UNITED STATEA EXTOMOLOGICAL COMMISSION.

(Nembers of the Commission: C. V. Riley, A. S. Packard, jr., and Cyrus Thomas.) *Bulletix No. 1.-Destruction of the youn: or unfledged Locusts (Caloptenus spretus). (1875.) [pp. 15.]

Bulletin No. 2.-On the Natural History of the Rocky Mountain Locust and on the habits of the young or unfledgerl insects as they occur in the more fertile country in which they will hatch the present year. (15\%.) [1]. 14, figs. 10.]

Bulletin No. 3.-The Cotton Worm. Summary of its Natural History, with an Aceount of its Enemies, and the best Means of controlling it; being a Report of Progress of the Work of the Commission. By Chas. V. Riley, M. A., Ph. D. (1880.) [p]. 14t, figs. 84, plates 1.]

Bullatin No. 4.-The Hessian. Fly. Its Ravages, Habits, Enemies, and Means of preventing its Increase. By A. S. Packard, jr.. MI. D. (18s0.) [p]. 43, figs. 1, plates 2., maps 1.]

* All of these bulletins and reports, with the exception of the fitth report, are out of print. 
Bulletin No. j.-The Chinch Bug. Its Ilistory, Characters, and Inabits, and the Means of lestroying it or comiterartering its In. juries. By Cyms Thomas, Ph. D. (1s-9.) [Pp. 4t, figs. 10, maps 1.] Bulletix No. 6.-General Index and supplement to the nine Reports (1) the Insects of Missouri. By Charles V. Riley, M. I.. Ph. I). (1581.) [11\%. 17\%.]

Bulletin No.7.-Insects injurions to Forest and Sharle Trees. By A. S. Packard, jr., M. 1). (1s81.) [pp. 275, figs. 100.]

Finst Ammual Report for the year 187\%, relating to the Rocky Monutaiu Locust and the best Methods of preventing its Injuries and of guarding against its Invasions, in pursunce of an Appropriation mate by Congress for this pmpose. With maps and illustrations. (187s.) [pp. 477+294, figs. 111, plates 5, maps 1.]

Second heport for the years 157 and 1879, relating to the Rocky Monntain Locust and the Western Cricket, and treating of the best Means of snboning the Loeust in its permanent Breding wromuls, with a view of preventing its Migrations into the more fertile Portions of the trans-Mississippi “omutry, in pursuance of Appropriations made by Congress for this purpose. With Maps and Il lustrations. (1Ss0.) [P1. xviII+320+20, figs. 10, plates 17. maps 7 . ] Third Report relating to the Rocky Momntain Locust, the Western Gricket, the Army Worm, Canker Worms, and the Hessian Fly: together with Descriptions of Larve of injurious Forest Insects, Studies on the embryological Development of the Loenst and of other Insects, and on the systematic Position of the Orthoptera in Relation to other Orlers of Insects. With Maps and Illustrations. (1883.) [pp. xvIII+347+91, figs. 14, plates 64 , maps 3.$]$

Fourth Report, being a revised Edition of Bulletin No.3, and the Final Report on the Cotton Worm and Bollworm. By Charles V. Riley,

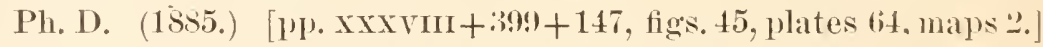
Fufth Report, being a revised and enlarged rolition of Bullotin No. 7, on Insects Injurious to Forest and Shade Trees. By Alphens S. l'ackard, M. D., P'h. D., with woodents amd 40 plates. (1s90 (1). small extition; only a few for general distribution.

BULLETINS OF TIIE DIVISION OF ENTOMOLGGY, U. S. DEPARTIENT OF AGRICULTURE, UNDER DIRECTION GF $\bullet$. V. RILEY, FNTOMOL()GIST.

*No. 1.- Reports of Experiments, chiefly with Kimseme, upon the Insects injurionsly affecting the Orangere Tres and the Cotton Plant, marle moder the Direction of the Entomologist. (1583.) [I1\%. 6.2.] *No. 2.-Reports of Observations on the Rocky Momutain Loenst and Ghinch Bug, together with Extrarets from the correspondence ot the Division on Miseellaneons Insects. (18,i3.) [1p..36.] 
*No. 3.-Reports of Observations and Experiments in the practical Work of the Division, made under the Direction of the Entomlogist. With plates. (1883.) [pp. iis, plates III.]

So. 4.-Reports of Observations and Experiments in the practical Work of the Division, made moler the Direction of the Entomologist, together with Extracts from Correspondence on miscellaneons Insects. (1884.) [pp. 102, tigs. 4.]

*No. 5.-Descriptions of North Ameriean Chalciliclie from the Collections of the C.S. Department of Agrienlture and of Dr. C. T. Riley, with biologieal Notes. [First paper.] Together with a list of the described North Ameriean species of the family. By L. O. Howard, M. Sc., Assistant, Bureau of Entomology. (1585.) [pp. 47.]

* No. 6.-The imported Elm-leaf Beetle. Its Habits and Natural His tory, and Means of counteracting its Injuries. (1885.) [pp. 18. tigs. 1 , plates I.]

No. ..-The Pedienli and Mallophaga affecting Man and the lower Animals. By Prof. Herbert Osborn. (1891.) [p1. 5 h figs. 4..]

*No. S.-The Periodical Cicada. An aceount of Cicadu septendecim and its tredicim race, with a chronology of all of the broods known. By Charles V. Riley, Ph. D. (1885.) [pp. t6, figs. 8.)

No. 9.-The Hulberry silk-worm; being a Manual of Instructions in Silk culture. By Charles V. Riley, 11. A., Ph. D. (1886.) [pp. 65, figs. 29, plates II.]

No. 10.-Our Shade Trees and their Insect Defoliators. Being a consideration of the fonr most injurious species which affect the trees of the eapital, with means of destroying them. By Charles V. Riley, Entomologist. (1857.) [pp. 7.j, figs. 27.]

*No. 11.-Reports of Experiments with various Insecticide Substances, chiefly upon Insects affecting garden Crops, made muler the Direction of the Eutomologist. (1886.) [pp. 34.]

*No.12.-Miscellaneous Notes on the work of the Division of Entomology for the Season of 1885; prepared by the Entomologist. (1886.) [pp. 4., plates I.]

*No. 13.-lieports of Observations and Experiments in the practical Work of the Division, made under the Direetion of the Entomologist. (With illustrations.) (1887.) [pp. 78, figs. 4.]

No. 14.-Reports of Observations and Experiments in the practical Work of the Division, made under the Direction of the Entomologist. (1887.) [pp. 62, figs. 2, plates I.]

No. 15.-The Icerya, or Fluted Scale, otherwise known as the Cottony Cushion-scale. (Reprint of some recent Articles by the Entomolo. gist and of a Report from the Agricultural Experiment Station, University of California.) (1887.) [pp. 40.]

No. 16.-The Entomologieal Writings of Dr. Alphens Spring Packird. By samuel Henshaw. (1887.) [pp. 49.] 
*No. 17.-The Chinch Bug: I general Summary of its History, Habits, Enemies, and of the Remedies and Preventives to be used against it. By L. O. IIoward M. S., Assistant Entomologist. (188s.) [p]. tis, tigs. 10.]

* No. 18.-The Life and Entomological Work of the late Townend Glover, first Entomologist of the Uniterl States I epartment of Agrienlture. P'repared under the Direction of the Entomologist, by C. R. Dodge. (18s8.) [1]. 68, figs. 1i, plates I.]

No. 19.-An entumeration of the published Synopses, Catalognes, and Lists of North American Insects; together with other information intended to assist the student of American Entomologr. (Istso.) [P]. $7 .$.

* No. 20.-The lioot Krnot Disease of the P'each, Orange, and other Plants in Florida, dne to the Work of Anguillula. Preparerl under the Direction of the Entomologist, by J. C. Neal, Ph. J)., M. D. (18s!.) [p1. 31, pliates 21.]

* No. 21.-Report of a Trip to Anstralia, made under the Direction of the Entomologist to investigate the Natural Enemies of the Fluted Seale, by Albert Koebele. (1890.) [pl. 32, tigs. 16.]

No. 22.-Reports of the Observations and Experiments in the practical Work of the Division, marle moler the Direction of the Entomologist. (1890.) [pp. 110.]

No. …-Reports of Observations and Experiments in the practical Work of the Division, mate muler the Direetion of the Entomologist. (1891.) [P). 83.]

No. 24.-The lioll Worm. Preliminary Report, made muler the Direc tion of the Eutomologist. By F. W. Mally. (1s91.) [p]. 50.]

No. 25.-Destructive Loemsts. A popular consideration of a few of the mure injurious Locusts or "Grasshopper's" of the United States, together with the best means of destroying them. By C. T. Riley, [Plı. D. (1891.) [11\%. 6. figs. 11, plates 12.]

†No. 2oti.-Reports of Observations and Experiments in the pratetieal Work of the Division, made miler the Direction of the Entomologist. (15:2.)

tNo. 27.-Reports on the Damage hy destructive Locusts during the season of 1 s!l, marle muler the Direction of the Entomologist. (1892.) [1]. 64.]

†No. 28. - The more destructive Lomsts of America, uorth of Mlexico, by Lawrence Brmer, prepared under Direction of the Entomologist. (15!2.)

FPLCIAL REPORTA ANI BULLETINS.

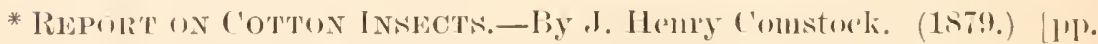
511 , figs. 77 , plates III.]

* Ont of print.

+ Bulletins 26 and 27 are in press, and Bulletin 28 is in comrse of preparation. 
† SPECIAL ReporT, No. 11.-The Silkwolm; being a brief Manual of Instructions for the Production of Silk. Prepared, by direction of the Commissioner of Agriculture, by C. V. Riley, M. A., Ph. I., Entomologist. (Finst erl., 1879; fifth ed., 1855.) [pp. 37, fign. 8.]

* Special Report', No. 35.-Report un Insects injurious to Sugar Cane. Prepared, under Direction of the Commissioner of A griculture, by

J. Henry Comstock, Entomologist. (1SS1.) [1]. 11, figs. 3.]

* Division af Entomology.-Insects AfFecting the Orange.Report on the Insects affecting the Culture of the Orange and other plants of the Citrus Family, with practical Suggestions for their

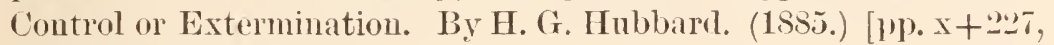
figs. 95, plates XIV.]

* śpecial Report.-Catalogue of the Exhibit of Ecomomic Entomology at the World's Industrial and Cotton Centennial Exposition, New Orleans, 1SS4-'S5. (1SSS.) [pp. 9.̃.]

Special Bulletin.-The Horu Fly (Hrematobia serrata), being an account of its Life-history and the means to be used against it. By C. V. Riley and L. O. Howard. (Reprinted fiom Insect Life. Tol. II, No. 4, October 1SS9.) (1Ss9.) [P]. 11, figs.5.]

Bibliography OF THE MORE important Contributions TO AMERican Economic Entonology. By Samuel Hemshaw. P'arts I, II, and III. The more important writings of Benjamin Dann Walsh and Charles Valentine Riley, Washington, 1890.

\section{HOW TO OBTALN ENTOMOLOGICAL BOOKS AND PAMPHLETS.}

Comparatively fer of the works treating of the elassification of North American inseets have been published as separate books; but such as have been so published, if of comparatively recent date, can be obtained through the regular book trade. By far the greater number of the monographs and syuopses mentioned in the preceding pages have been published in seientific periodicals and in the proceedings $01^{\circ}$ transactions of scientific societies. These may be obtained either through the societies or through the publishers; but single volumes of transactious or proceedings, and more especially single papers, are seldom sold, and the older volumes are liable to be out of print. Horeover, the expense attending the purchase of all of the periodicals containing the publications on a given oreler of insects will be so great as to put them beyond the reach of most entomologists. The enstom of placing at the disposal of authors a number of separate copies of their papers overcomes this difficulty to some extent and creates a smali supply. Thus it often happens that a person interested can obtain a copy of a scientific paper by adtressing the anthor personally. Many of

\%out of print.

t Bull. No. 9 of the Dirision of Entomologr covers this subject.

2561 $-10$ 
these separate copies also fall into the possession of dealers in secondhand books, and may be purchased from them. The Ameriean Entomological Society of Philadelphia, and also a few other societies here aud in Europe, offer for sale from their duplicates many of these authors' extras, and in some cases publish lists. There are, moreover, certain business establishments which make a specialty of the sale of works and pamphlets on natural history, including entomology, and it is chiefly throngh such establishments that the student is enabled to seemre the larger portion of the works needed.

By subseribing to the entomologieal periodicals published in this country (a matter of but slight expense) the student may keep abreast of the current literature. Short book reviews or notes published therein call attention to the more important publications in other countries. Horeover, the Zoölogischer Anzeiger, edited by Prof. J. Victor Carus, in Leipzig, Germany, and published every fortnight, gives a tolerably complete bibliography of the eurrent entomological literature at intervals of about six or eight weeks. The "Nature Novitates," published every fortnight by R. Friedlaender \& Sohn, Carlstrasse. 11, Berlin, Germany, gives the titles of most recent works and pamphlets.

There are also three great anmul publications, viz: "Die Fortschritte auf dem Gebiet der Entomologie," published in Wiegmann's "Archir fiir Naturgeschichte;" "The Zoïloginal Rerord," published by the Zoölogical Record Society, in London, England; and the "Zoölogische Jahresherichte," published by the Zoülogical Station at Naples, Italy, which give the full literature of the previous year, discussing the more important papers and giving a list of the new species, besides other information. These three publications are almost indispensable to the student in any branch of zoölogy, and some one of them at least onght to be found in every public library in the country. The volumes of the "Zoülogische Jahresberichte" since 1887 contain no titles upon sirs. tematic and classificatory zoölogy, but only such as refer to biology.

A not inconsiderable portion of the North American literature on the chassifieation of inseets has been published hy the Government of the United States throngh various channels, foremost anong which are the Smithsonian Institution, the U. S. Department of Agrienlture. the U. S. National Musemu, the U. S. Geological and Geoglaphieal Survey, and the various surveys of the Territories. Some of these publieations are distributed free of cost; while other's, like wertain of the pulblications of the Smithsonian Institution and the Geolugioal Survey, are sold at a moderate price to cover the const of publication. Nany of them are out of print, and can only be obtained throngh natural history book-dealer's.

Of the more general works, some may be olstained disect from the publisher's, and in such eases the publishers are mentioned in the general list. 'The older works are mostly ont of print and ean only he ohtained from second-hand dealers. The current State reports of Lintner and Forbes maty be obtained from the secretaries of the respective 
State agricultural societies at Albany, $\mathbf{Y}$. I., and Springtield, Ill., while the bulletins and reports of the entomologists of the varions State experiment stations, of which a large number are being published, may be obtained from the direetors of the respective stations. The older reports of the State entomologist of Hissomi and the State entomologists of Illinois (Walsh, Le Baron, and Thomas) are all out of print and can only be obtained by purchase from second-hand dealers. The same may be said of the well-known and oft-puoted reports of Dr. Fit.h. which were published with the old volumes of the Transactions of the New York State Agricultural Society. 

$-$

$=$

.

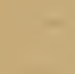


